\title{
POLITICAL COMMUNICATION AND CONSTRUCTION OF THE NEO-LIBERAL HEGEMONIC PROJECT: \\ ONTARIO IN TRANSITION, 1995-1997
}

\author{
by \\ KIRSTEN KOZOLANKA, \\ B.A., M.A., M.J. \\ A thesis submitted to \\ the Faculty of Graduate Studies and Research \\ in partial fulfillment of \\ the requirements for the degree of
}

Doctor of Philosophy

Department of Communication

Carleton University

Ottawa, Ontario

September 12, 2003

(C) 2003, Kirsten Kozolanka 


\author{
National Library \\ of Canada \\ Acquisitions and \\ Bibliographic Services \\ 395 Wellington Street \\ Ottawa ON K1A ON4 \\ Canada
}

Bibliothèque nationale

du Canada

Acquisisitons et services bibliographiques

395 , rue Wellington Ottawa ON K1A 0N4 Canada
Your file Votre référence ISBN: 0-612-88724-3 Our file Notre référence ISBN: 0-612-88724-3
The author has granted a nonexclusive licence allowing the National Library of Canada to reproduce, loan, distribute or sell copies of this thesis in microform, paper or electronic formats.

The author retains ownership of the copyright in this thesis. Neither the thesis nor substantial extracts from it may be printed or otherwise reproduced without the author's permission.
L'auteur a accordé une licence non exclusive permettant à la Bibliothèque nationale du Canada de reproduire, prêter, distribuer ou vendre des copies de cette thèse sous la forme de microfiche/film, de reproduction sur papier ou sur format électronique.

L'auteur conserve la propriété du droit d'auteur qui protège cette thèse. $\mathrm{Ni}$ la thèse ni des extraits substantiels de celle-ci ne doivent être imprimés ou aturement reproduits sans son autorisation.
In compliance with the Canadian Privacy Act some supporting forms may have been removed from this dissertation.

While these forms may be included in the document page count, their removal does not represent any loss of content from the dissertation.
Conformément à la loi canadienne sur la protection de la vie privée, quelques formulaires secondaires ont été enlevés de ce manuscrit.

Bien que ces formulaires aient inclus dans la pagination, il n'y aura aucun contenu manquant. 
THESIS ACCEPTANCE FORM

PH.D. IN COMMUNICATION CANDIDATE

The undersigned hereby recommend to the Faculty of Graduate Studies and Research acceptance of the thesis

\title{
Political Communication and Construction of the Neo-Liberal Hegemonic Project: \\ Ontario in Transition, 1995-1997
}

\author{
submitted by \\ Kirsten Kozolanka, B.A., M.A., M.J. \\ in partial fulfilment of the requirements \\ for the degree of Doctor of Philosophy
}

Chair, School of Journalism and Communication

Thesis Supervisor

Carleton University

2003 


\begin{abstract}
This thesis is about the key legitimating role of communication in constructing neoliberalism in Ontario in the transitional period from 1995 to 1997 after the Conservatives came to government. It provides an historical review of the development of the intellectual and material framework to support the neo-liberal paradigm, its manifestation in different jurisdictions and its appearance in Canada. Using Gramsci's theory of hegemony, it demonstrates that the processes of legitimation undertaken by the Ontario neo-liberal government in order to gain consent for its hegemonic project prior to its coming to power were part of a "war of position" to replace the post-World War II Keynesian compromise and establish the neo-liberal paradigm. In its first two and a half years in power, however, resistance to the government was sufficiently strong and the government sufficiently ideological in its approach that it faced a "crisis of authority" and risked losing its "historic bloc" at a transitional time that is vulnerable to counter-hegemonic struggle.

The thesis also demonstrates that a neo-liberal hegemony and the legitimating efforts to establish and maintain consent have impacts on political communication represented by government, media and the public sphere. In three case studies, the thesis also examines contestation and resistance to the emergent hegemony in Ontario through media content analysis and examination of the communications and discursive strategies of the government and its challengers, drawing on Stuart Hall et al's social production of news and Raymond Williams' concepts of dominant, alternative and oppositional meaning systems. Ultimately, the strongest challenge to the government, a coalition of labour and social movements that organized ongoing Days of Action around the province, was unable to develop and maintain an organic and cohesive "war of position" or form a "historic bloc" to counter the government, while the government drew on the legitimating apparatus of the state to regain consent and to reabsorb control. Despite this success, as Peter Golding has demonstrated, this thesis confirms that ideological reproduction is not given but won or lost in struggle. To this end, an example of a failed government initiative is also examined. Finally, this thesis also looks at the possibilities for the construction of counter-hegemony through communicative democracy.
\end{abstract}




\section{ACKNOWLEDGEMENTS}

Many people have helped this thesis project become a reality. At Carleton University, I was honoured to work with scholars as fine as Vincent Mosco, who was my first thesis supervisor and who patiently and expertly brought me through the first chapters, and Karim H. Karim, my second supervisor, who has been a wise and steady guide in the final stage of the journey, making many insightful comments as well as giving me faith to continue as the project wore on. The comments of the other Carleton members of the thesis committee, Catherine McKercher and Dwayne Winseck (until June 2003 and now on sabbatical), pushed me to work harder and look further, and the finished thesis is the better for it. I was fortunate to have Graham Knight as external examiner on the committee and appreciate the participation of Carleton's Political Science department through Jonathan Malloy, the internal examiner on the committee.

I would also like to thank the other professors in the program under whom I have studied for sharing their knowledge: Paul Attallah, Michael Dorland, Ross Eaman, Michèle Martin and Eileen Saunders. I am grateful to Eileen particularly for both introducing me to mass communication studies (in her Media and Society course in 1985) and writing the letter of reference for my application to the doctoral program. Thanks also to Peter Johansen for remembering my interest in doctoral studies and contacting me once the program became a reality. I would not have been as wellprepared for the program without the help of Eileen and Peter and those other journalism professors in Carleton's M.J. program under whom I studied: Peter Bruck, Clyde Sanger and Brian Taylor. University of Ottawa professors Sherry Devereaux Ferguson and Leslie Regan Shade also were endlessly encouraging and helpful.

The Carleton community has been very supportive, from the reference and interlibrary loan librarians to administrative employees, including Carole Craswell of the Mass Communication Program. The sisterhood of doctoral students Anne-Marie Kinahan, Pat Mazepa and Dina Salha kept me moving forward, and I am grateful to them.

The people I interviewed for this project gave unstintingly of their time and helped give perspectives that would otherwise have been missing. Their interest and contribution to the project are very much appreciated.

I would also like to acknowledge my supervisors and colleagues at Indian and Northern Affairs Canada, my other life, who have always supported my studies, despite finding themselves short-handed on many an occasion while I was at the university. Their excitement and pride in my efforts were strong motivation.

My extended family and friends, especially Kim and Susi, have been a steady source of support. Finally, I could not have accomplished this without the loving support of my family, Charles, Honor and Greer. Six years and 468 pages later, words still cannot express my gratitude to them. 


\section{LIST OF ACRONYMS}

\begin{tabular}{|c|c|}
\hline $\mathrm{BCNI}$ & Business Council on National Issues \\
\hline $\mathrm{CC}$ & Communication Canada \\
\hline CCPA & Canadian Centre for Policy Alternatives \\
\hline CEP-NABET & $\begin{array}{l}\text { Communications, Electrical and Paperworkers Union- } \\
\text { National Association of Broadcast Employees and Technicians }\end{array}$ \\
\hline C4LD & Citizens for Local Democracy \\
\hline $\mathrm{CHC}$ & Canadian Heritage Canada \\
\hline CPBF & Centre for Press and Broadcast Freedom - Canada \\
\hline $\mathrm{CPE}$ & Coalition for Public Education \\
\hline CPS & Centre for Strategic Studies \\
\hline CSR & Common Sense Revolution \\
\hline CUPE & Canadian Union of Public Employees \\
\hline EDU & European Democratic Union \\
\hline FI & Fraser Institute \\
\hline FTA & Free Trade Agreement \\
\hline FTAA & Free Trade Agreement of the Americas \\
\hline GATT & General Agreement on Tariffs and Trade \\
\hline IEA & Institute of Economic Affairs \\
\hline IIE & Institute for International Economics \\
\hline IMF & International Monetary Fund \\
\hline LCBO & Liquor Control Board of Ontario \\
\hline MCSJ & Metro Centre for Social Justice \\
\hline MEdT & Ministry of Education and Training, Ontario \\
\hline MMAH & Ministry of Municipal Affairs and Housing, Ontario \\
\hline NAFTA & North American Free Trade Agreement \\
\hline NATO & North Atlantic Treaty Organization \\
\hline $\mathrm{NCC}$ & National Citizens' Coalition \\
\hline OCAP & Ontario Coalition Against Homelessness \\
\hline OEA & Ontario Education Alliance \\
\hline OECD & Organization for Economic Cooperation and Development \\
\hline OISE & Ontario Institute for Studies in Education, University of Toronto \\
\hline OLRB & Ontario Labour Relations Board \\
\hline ONG & Ottawa Newspaper Guild \\
\hline OP & Office of Privatization, Ontario \\
\hline OPEC & Organization of the Petroleum-Exporting Countries \\
\hline OPSEU & Ontario Public Service Employees Union \\
\hline OTF & Ontario Teachers' Federation \\
\hline PDU & Pacific Democratic Union \\
\hline P4E & People for Education \\
\hline TC & Trilateral Commission \\
\hline TVO & TVOntario (Ontario Educational Communications Authority) \\
\hline WB & World Bank (International Bank for Reconstruction and Develo \\
\hline WTO & World Trade Organization \\
\hline
\end{tabular}


TABLE OF CONTENTS

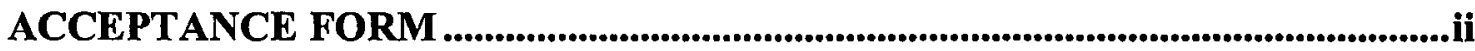

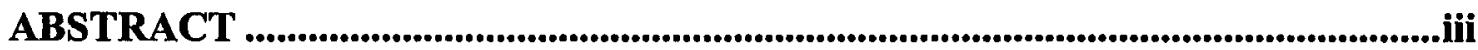

ACKNOWLEDGEMENTS ................................................................................................ iv

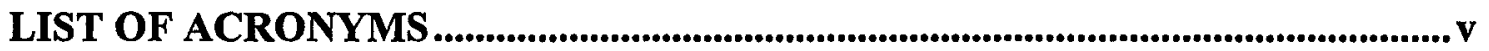

TABLE OF CONTENTS ............................................................................................ vi

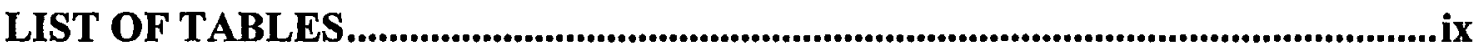

CHAPTER 1: HEGEMONY, NEO-LIBERALISM AND

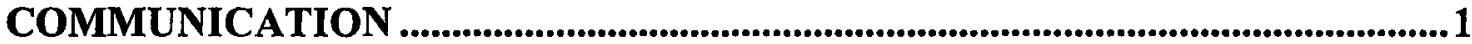

Background and Literature Review ...........................................................

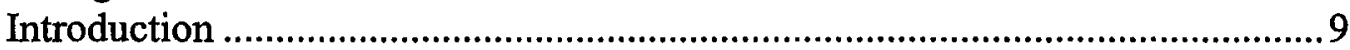

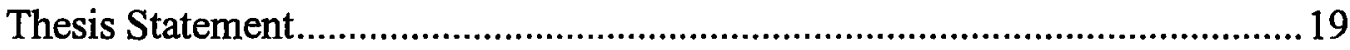

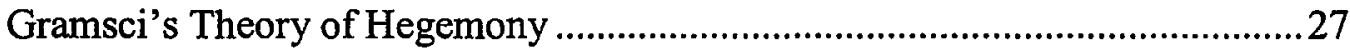

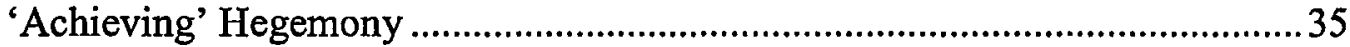

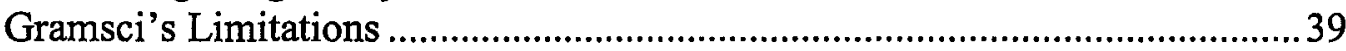

Theoretical Approach .................................................................................. 41

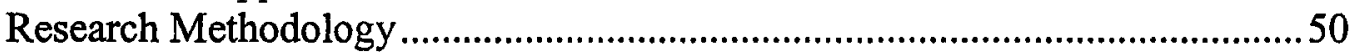

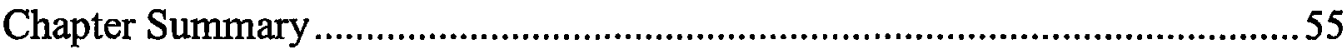

\section{CHAPTER 2: THE NEO-LIBERAL PROJECT: TRANSFORMATION}

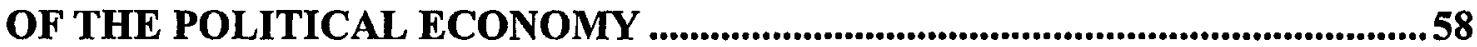

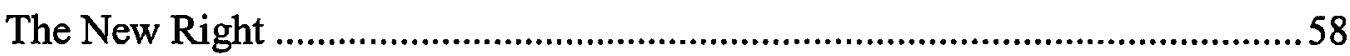

The Post-WWII Political and Economic Environment ..................................6. 63

Cracks in the Politics of Equilibrium ..........................................................67

The Growth and Influence of Elite Corporate Institutions ..............................770

The Attack on Keynesianism and the Transition to Neo-Liberalism ................ 78

The Construction of Neo-Liberalism in the United Kingdom..........................8 82

The Influence of the American New Right ..................................................90

The Construction of Neo-Liberalism in New Zealand .....................................96

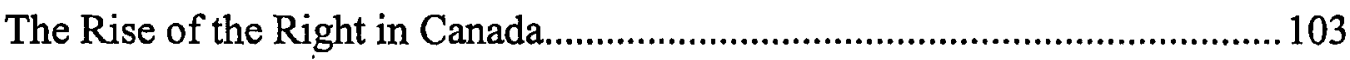

The Construction of Neo-Liberalism in Ontario .............................................116

Conclusion: The Transformation of the Political Economy..........................129 


\section{CHAPTER 3: POLITICAL COMMUNICATION: LEGITIMATION AND CONSENT FOR THE NEO-LIBERAL PROJECT.}

Introduction 138

The State: Restructuring and Governmentality under Neo-Liberalism............ 143

The State: Government Information and Communication Management ......... 148

The State: The Mass Media and the Political Process..................................... 164

The Public Sphere: Social Citizenship and Neo-Liberalism ........................... 166

The Public Sphere: Social Movements and Resistance..................................170

The Public Sphere: Constructing Legitimation and Consent .......................... 175

The Mass Media: Media Practice and the Construction of Hegemony ............ 189

The Mass Media: Media Systems and Commercialization .............................. 198

Conclusion: Political Communication and Consent........................................204

\section{CHAPTER 4: CONSTRUCTING AND COMMUNICATING} NEO-LIBERALISM IN ONTARIO: THE CASE STUDIES I...............................210

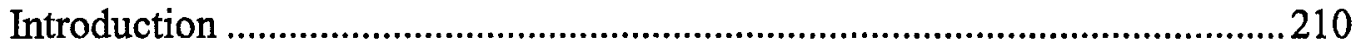

Ontario, Neo-Liberalism and the Global Economy......................................2 215

Introduction to the Case Studies...................................................................2218

Case Study 1: The Public Service Strike and the Days of Action...................223

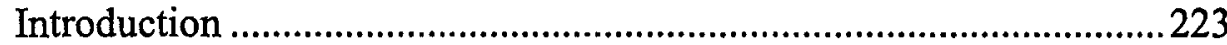

Government Communication Strategy ...........................................2227

Challenger Communication Strategy .................................................2229

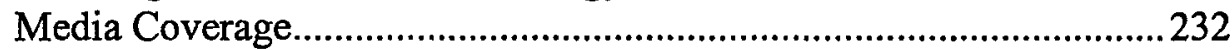

Public Opinion..............................................................................249

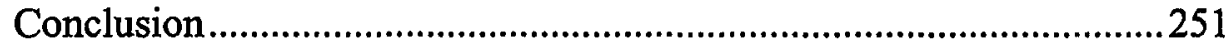

Case Study 2: The Amalgamation of Toronto and Megaweek .......................256

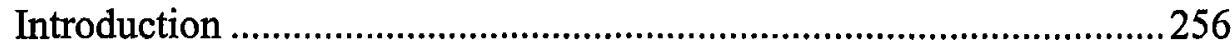

Government Communication Strategy ...........................................260

Challengers and their Communication Strategies ..............................263

Media Coverage..............................................................................266

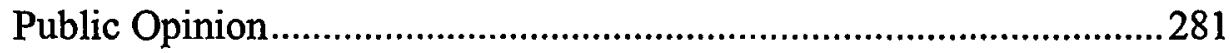

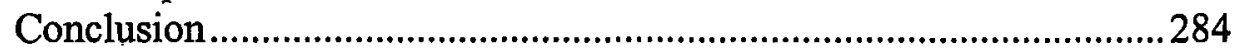

Case Study 3: The Education Quality Improvement Act

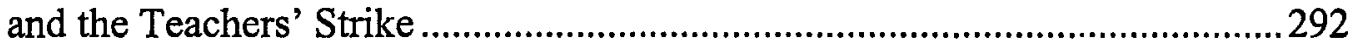

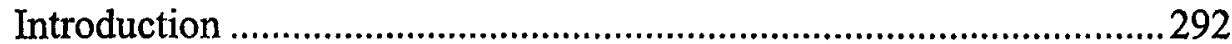

Government Communication Strategy ............................................2296

Challengers and their Communication Strategies .............................. 298

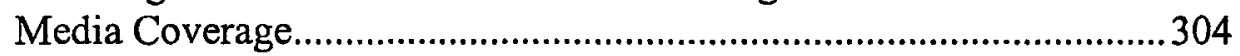

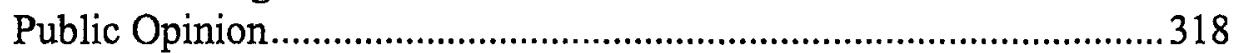

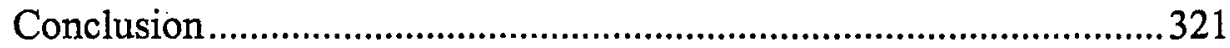




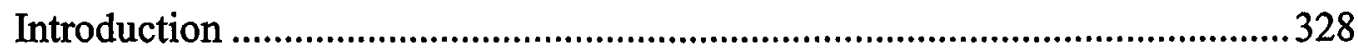

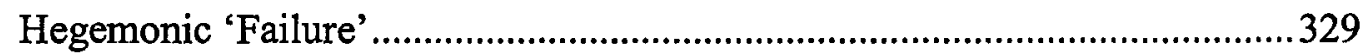

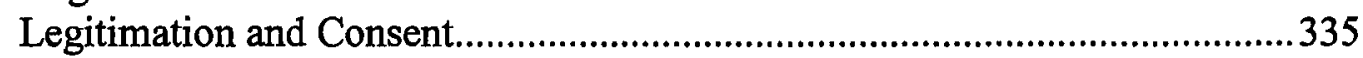

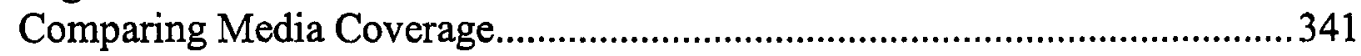

Government Communication Strategies.................................................... 347

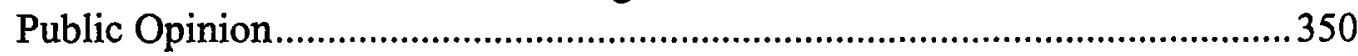

Challenger Communication Strategies ...................................................... 352

The Days of Action and Resistance...........................................................357

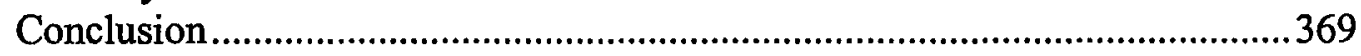

\section{CHAPTER 6: COUNTER-HEGEMONY AND COMMUNICATIVE}

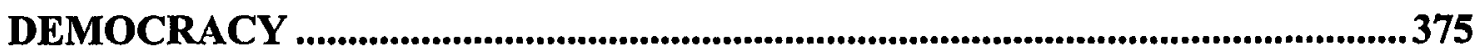

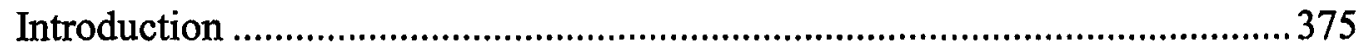

Neo-liberalism as New Polity....................................................................375

Resistance and Counter-Hegemony ........................................................ 384

Legitimation, Consent and Communicative Democracy.................................400

Gramsci, Hegemony and Post-Neo-Liberal Transformation........................... 415

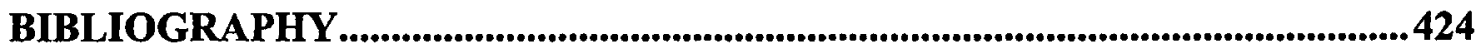




\section{LIST OF TABLES}

$1 \quad$ Ontario Provincial Election Results, $1981-95$...............................................118

2 Chronology: Ontario Public Employee (OPSEU) Strike and Days of Action.224

3 Political Actors in Mainstream Print Media Coverage on the OPSEU Strike (February 25-March 31, 1996) ......................................................................236

4 Proportional Presence and Disposition of Political Actors in Mainstream Print Media Coverage on the OPSEU Strike (February 25- March 31, 1996)..........238

5 Phases in Mainstream Print Media Coverage of the OPSEU Strike (February 25-March 31, 1996)

6 Authoritative Actors and Challengers in Mainstream Print Media Coverage on the OPSEU Strike (February 25-March 31, 1996) .......................................241

7 Type of Media Coverage in Mainstream Media: OPSEU Strike (February 25March 31, 1996)

8 Type of Media Coverage in Business Media: OPSEU Strike (February 25March 31, 1996)

9 Type of Media Coverage in National Broadcast Media: OPSEU Strike (February 25-March 31, 1996)

10 Government Messages on the OPSEU Strike (February 25-March 31, 1996). 245

11 Challenger Messages on the OPSEU Strike (February 25-March 31, 1996) ...246

12 Chronology: Amalgamation of Toronto and Megaweek .257

13 Political Actors in Mainstream Print Media Coverage on the Megacity (December 17, 1996-April 21, 1997)

14 Proportional Presence and Disposition of Political Actors in Mainstream Print Media Coverage on the Megacity (December 17, 1996April 21, 1997) 269

15 Phases in Mainstream Print Media Coverage of the Megacity (December 17April 22, 1997)

16 Authoritative Actors and Challengers in Mainstream Print Media Coverage on the Megacity (December 17-April 22, 1997) 
17 Type of Media Coverage in Mainstream Media: Megacity (December 17April 22, 1997) .........................................................................................275

18 Type of Media Coverage in Business Media: Megacity (December 17April 22, 1997) 275

19 Type of Media Coverage in National Broadcast Media: Megacity (December 17-April 22, 1997) 275

20 Government Messages on the Megacity (December 17-April 22, 1997)........277

21 Challenger Messages on the Megacity (December 17-April 22, 1997) ...........278

22 Chronology: The Education Quality of Improvement Act (Bill 160) ..............293

23 Political Actors in Mainstream Print Media Coverage on Bill 160 (Education) (September 22-December 2, 1997) 305

24 Proportional Presence and Disposition of Political Actors in Mainstream Print Media Coverage on Bill 160 (Education) (September 22-December 1, 1997). 306

25 Phases in Mainstream Print Media Coverage of Bill 160 (Education) (September 22-December 2, 1997). 308

26 Authoritative Actors and Challengers in Mainstream Print Media Coverage on Bill 160 (Education) (September 22-December 2, 1997) 310

27 Type of Media Coverage in Mainstream Media: Bill 160 (Education) (September 22-December 2, 1997).

28 Type of Media Coverage in Business Media: Bill 160 (Education) (September 22-December 2, 1997).

29 Type of Media Coverage in National Broadcast Media: Bill 160 (Education) (September 22-December 2, 1997).

30 Government Messages on Bill 160 (Education) (September 22-

December 2, 1997)

31 Challenger Messages on Bill 160 (Education) (September 22December 2, 1997)

32 Political Party Preference in Ontario, Days of Action and Case Studies, 1995-97 
CHAPTER 1: HEGEMONY, NEO-LIBERALISM AND COMMUNICATION

\section{Background and Literature Review}

This thesis is about the key role of communication in constructing neo-liberalism in Ontario in the transitional period of it's the Conservative government from 1995 to 1997. It provides an historical review of the development of the intellectual and material framework to support the neo-liberal paradigm, its manifestation in different jurisdictions and its appearance in Canada. Using Gramsci's theory of hegemony, it aims to demonstrate that the processes of legitimation undertaken by the Ontario neo-liberal government in order to gain consent for its hegemonic project were part of a "war of position" to replace the post-World War II Keynesian compromise and establish the new hegemonic paradigm. It also aims to demonstrate that a new neo-liberal hegemony as well as the legitimating efforts to maintain it has impacts on political communication, represented by government, media and the public sphere. In three case studies, the thesis also examines contestation and resistance to the emergent paradigm in Ontario through media content analysis and examination of the communications strategies of the government and its challengers. It also probes the limits of ideological reproduction in reviewing instances in which the Ontario government chose to either retreat or leave unaddressed some components of its agenda. Just as it examines the development of the neo-liberal project in Ontario, this thesis also looks at the possibilities for the construction of a counter-hegemonic project through communicative democracy. 
The inspiration for this thesis came from an article in Media, Culture and Society that compared two government communications campaigns to sell their policies. Scott, in "Communication Campaigns and the Neo-Liberal Policy Agenda" (1997), compared the failure of the 'poll tax' in Great Britain in 1991 to the success of the employment contracts legislation in New Zealand in 1991. Both government communication campaigns were launched in the context of the restructuring policies of neo-liberal governments that were blatantly ideological in pursuing their goal of restructuring the state. Scott demonstrated that power can be exercised through political communication if the government maintains ideological coherence and there is a high degree of consensus among elites and media sources and audiences (Scott, 1997:197). References led to a rather thin body of literature, headed by the British poll tax study by Deacon and Golding, Taxation and Representation: The Media, Political Communication and the Poll Tax (1994).

That study of political communication was intended to gain an understanding of "the significance of the mass media in modern political culture, and the processes by which media agendas are politically generated" (viii). The case study chosen was significant because it analyzed a policy failure, thereby drawing attention to the limits of ideological reproduction and the conditions under which a "flagship" policy could fail. Deacon and Golding's conclusions drew attention to the lack of political cohesion in the government ranks, the organized and well-resourced opposition and strong local media. On broader theoretical issues, they emphasized the importance of communications factors in explaining policy 
failures, looking closely at the media process in non-election periods and reassessing the model of primary definition (Hall et al, 1978).

The comment on primary definition led backward to Policing the Crisis (1978) in which Hall et al lay out the social production of news and the primary definition hypothesis. In the case of the poll tax, the ideological framing advantage accorded primary definers (here, the government) was "eroded by political vulnerability, so that an 'accredited' source becomes 'discredited"' (Deacon \& Golding, 1994:202). Deacon and Golding add a corollary to the primary definer hypothesis that not only must it be won, it must be sustained. This reconfigured hypothesis is useful to this thesis in demonstrating the contestation amongst authoritative sources.

In a separate article on the poll tax debacle, Golding (1992) explores how capitalism is communicated and the conditions under which the limits of ideological dominance can be reached. He concludes that in the communications environment under the Thatcher governments of 1979-90, "the media have been the dominant vehicle via which ideas have been propelled" (Golding, 1992:506), but goes beyond 'media effects' to locate his analysis within "a more elaborate comprehension of the media-society complex" (506). The hope of this thesis also is to examine the broader conditions in which this relationship interacts.

My examination of Hall et al's work led to Hall's analyses of Thatcherism, the contextual backdrop of Taxation and Representation. In The Hard Road to Renewal (1988), Hall defines and analyzes the unique and specific character and significance of the political project of Thatcherism. He examines the reason for its 
success in "redrawing the political map and disorganizing the left" (Hall, 1988:272). His analysis draws on Gramsci's theory of hegemony from the latter's main work, Selections from the Prison Notebooks (1971), which he uses to articulate the depth and breadth of the Thatcher project. In Gramscian terms, Thatcherites waged a "war of position", they built an "historic bloc", they, in their role as "organic intellectuals", remade "common sense" within "civil society"; in short, they constructed a new "hegemony."

Hall's explanation of Thatcherism as an emergent hegemony resonated deeply with events that were happening in Ontario under a new, overtly ideological government with a similar political agenda. The story of the clash of ideologies in Ontario, the resistance and opposition to the government, the use of political communication and the ideological limits of Ontario neo-liberalism forms this thesis. Drawing on the initial inspiration provided by Scott (1997), this thesis reviews and applies the hypotheses and analysis of Hall, Golding, and Deacon and Golding using Gramsci's theory of hegemony as theoretical framework.

A literature review shows an uneven development of literature related to this subject. On neo-liberal theory, the theorization is rich in scope. Levitas (1986) is seminal in drawing out the origins of the various strands of conservatism and liberalism that comprise neo-liberalism. Critical and Marxist political economists have been in the forefront, beginning with the annual Socialist Register, particularly the 1992 version edited by Panitch and Miliband that looks at 'the new world order'. Marxism Today, British in origin, has also sparked debates on the crisis of the Left under Thatcherism. The Marxism Today body of work was reproduced in an early 
volume edited by Hall and Jacques, New Times: The Changing Face of Politics in the 1990s (1989). Jessop $(1985,1989,1997)$ and Jessop et al $(1984,1988,1990)$ have added to an understanding of Thatcherism from a more structural Marxist perspective, which provides balance with Hall's more culturalist Marxist perspective.

The New Zealand experience with neo-liberalism has also been welldocumented in Gold's series, New Zealand Politics in Perspective (1985, 1989, 1992), an edition of which follows each general election in that country. Gold has compiled academic essays on different aspects of neo-liberal state restructuring, including pressure groups and lobbying, resistance, business political activism and electoral trends, all of which have provided background and a model with which to compare Ontario's project. Roper and Rudd's 1993 volume, State and Economy in New Zealand, and Sharp's Leap into the Dark: The Changing Role of the State in New Zealand since 1984 (1994) contain a similar range of essays. Kelsey (1994, $1995,1999)$ situates state change under neo-liberalism within the context of structural adjustment policies in the international sphere. She also proposes an agenda for Reclaiming the Future, the title of her 1999 book, which fits with the aim of this thesis to explore counter-hegemony. Larner (2000:14-6) brings theoretical understanding to how neo-liberalism works through policy, ideology and governmentality in her analysis of New Zealand market reform, calling for a focus on the "historically contingent and internally contradictory aspects, rather than its coherence" in order to reveal the "contradictions, complexities and inconsistencies" of a neo-liberal project-a task which is taken up in this thesis. In exploring 
Larner's suggested focus, the work on social movements of Leys and Mendell (1992) and Carroll (1997) offered theoretical and practical analysis of organized resistance in Canada. Gitlin (1980) also provided an important analysis of social movements and the challenge to survive as a movement while seeking to gain access to the media that relied on both Gramsci (1971) and Williams (1977), as does this thesis.

In Canada, analysis is of course centred on the federal level of government and the nature of its move to the Right, which does not fall into the 'usual' neoliberal pattern found in Great Britain and New Zealand. Influential academic analysts include Panitch and Swartz (1988), with a more structural functionalist perspective of this new phase in capitalism; Jenson (1989) on Canada's different Fordist development; McBride $(1992,1996)$ on the process of legitimation and labour; Laxer (1996), an early critic of the Canadian Left's lack of coherent and resonant economic policy; and Clement and Vosko (2003) on transformation and radical political economy in Canada. All of these help to build understanding of the historical, political and economic conditions underlying the growth of the New Right in Canada and the emergence of neo-liberalism in Ontario.

Several volumes of research and analysis have emerged out of the ongoing Ontario experience, but the pace of analysis seems slow compared to the quick pace of the province's restructuring agenda. Ralph et al (1997) produced perhaps the first volume of essays on this subject and their perspective is confined to the eventful first year of the Conservatives in power. Issues addressed include: the debt discourse, social citizenship, ties to American Conservatives, social service cuts, 
direct action against the government and radical strategies for change. A second volume of essays, edited by Noel (1997), contains more in-depth academic analysis, including articles on policy making, electoral patterns, election advertising and the new government as a fundamental shift in Ontario politics. This helps to situate Ontario's project as historically and jurisdictionally specific.

Two volumes have examined aspects of the case studies in this thesis and provide useful details of events and processes. Rapaport (1999) writes an account of the Ontario Public Service Employees' Union (OPSEU) strike against the government from inside the union and Boudreau (2000) discusses democracy and citizenship issues in the Toronto-centred resistance to that city's amalgamation with suburban cities surrounding it. More broadly, the popular sector has also written about Canada and Ontario in volumes ranging from Council of Canadians co-chair Clarke $(1997,2000)$ on the co-optation of the country by corporate interests to the ongoing research and publications of the progressive think tank, Canadian Centre for Policy Alternatives (CCPA), particularly its alternative budget series, which has developed an alternative template for looking at the economy. The CCPA also publishes an education journal, Our Schools/Our Selves, which contributes to scholarship on education in Ontario and elsewhere in Canada and that was therefore useful in providing background in the education case study in this thesis.

Neo-liberalism in Ontario remains an ongoing project and analysis has yet to catch up to political reality. In marked contrast, Studies in Political Economy has devoted considerable space to analyzing the neo-liberal phenomenon, both in other jurisdictions (Larner, 1996; Neilson, 1998) and sectoral articles (Munro, 1997; 
Winfield and Jenish, 1998; Conway, 2000), as well as in articles that situate the neoliberal project theoretically (Bradford, 1999; Jackson, 2001; Larner, 2000; Workman, 1999).

The turn to the Right and the collapse of the post-war Keynesian consensus have been taken up as objects of analysis by Gill $(1988,1992)$ and Robinson (1996), both from a Gramscian perspective. Gill's analysis centres on the influence of international elites, many originating in the US, in the new global world order and Robinson examines the policy of democracy promotion as serving the aims of hegemony. They provide the linkages from state neo-liberal hegemonic projects to the international and transcorporate environment that enables a broader understanding of the extension of the interests and networks of capital at play in a 'globalized' world.

The communications aspects of neo-liberalism are, unfortunately, relatively undertheorized. Fortunately, the work of Mosco (1996), Herman and McChesney (1998), and Herman and Chomsky (1988) provides a rich theoretical source for analysis within a political economy of communication that is critical in approach and implicitly transformative, and thus contributes to this thesis's understanding of how neo-liberalism is structured and maintained. From the perspective of advocates of market-based reforms, Williamson's (1994) handbook detailing how to construct a neo-liberal state project barely mentions communications. Its advice to would-be market reform or neo-liberal programs consists of the suggestion to bypass the media: "In the sort of pluralistic and market-oriented society that reformers are trying to build, the media will not be a 
pliant agent..." (587). In Great Britain, the work of Hall has already been mentioned. In New Zealand, two analysts are of note: Atkinson $(1989,1994)$, who connects neo-liberal communication with what he calls 'thin' (representative) democracy; and Easton $(1989,1994,1996)$, who first conceived neo-liberal communications campaigns as "blitzkrieg"-style attacks. In Canada, Hackett (1991, $1996,1998,2000$ ) has probed systemic absences in the media and has stressed the importance in neo-liberal times of developing a movement for "communicative democracy", a concept that is taken up in this thesis's concluding chapter.

\section{Introduction}

In 1974, after two electoral defeats in the same year, the Conservative Party of Great Britain elected an obscure Cabinet minister to be its next leader. Her name was Margaret Thatcher and her only public profile before her election was when as Minister of Education she cut the budget for providing children from low-income families with free milk at school. This action earned her the nickname "Thatcher, Milk Snatcher" (Travis, 2002:1), but, more importantly, it presaged a significant shift in the economic, social, cultural, political and ideological relations of the country. It was an initial sign of a historically significant project from the political Right that became known as 'Thatcherism', and its repercussions were to be felt throughout Western industrialized nations. Unlike traditional, election-focused political projects, "it entered the political field in a historic contest, not just for power, but for popular authority, for hegemony" (Hall, 1988a:164). 
Within five years, Thatcher was Prime Minister and a similar project, called 'Reaganomics', was underway in the United States. Within 10 years, as 'Rogernomics', it was underway in New Zealand. Within 15 years, it arrived in Canada, first on the federal scene and later more aggressively in Alberta (in 1992) and then Ontario (in 1995). The project was manifested differently in each jurisdiction where it proliferated, but it had a common purpose and common elements. Its aim was to restructure the post-war consensus that was known as the Keynesian welfare state through a comprehensive program oriented to economic liberalism and social conservatism. The primary policy tools it used to restructure the state reflected economic liberalism: privatization of public institutions, downsizing of the public service, tax reform in the shape of tax cuts and deregulation of financial markets. The social conservative aspect of the project was manifested in a renewed state focus on defence, justice and family issues. The rising influence of the United States, which was on its way to becoming the world's single 'superpower', was felt in its own national neo-liberal project of 'Reaganomics' and an international hegemonic project of structural adjustment, which was essentially market reform in non-industrialized countries of the majority world.

Just as the political project that began in Great Britain took many forms, it was called by many names. One side of the coin was 'structural adjustment' or the 'Washington consensus', as it was also known, reflecting a hegemonic response to international development and globalization. The other side of the coin was the 
state-led political project that was often called 'neo-conservatism', but which coalesced under the name 'neo-liberalism'.'

Neo-liberalism did not appear as a sudden break from the past or a rupture (Levitas, 1986), but was constructed out of the economic and social crises that plagued Western nations throughout the late 1970 s and the 1980 s, with recurring recessions and a new economic problem, stagflation. Democratization movements with their aspirations for social inclusion had expanded the welfare state, but in turn had stimulated the large state bureaucracies that were increasingly harder to sustain through tax revenue while servicing national debts.

Despite the gradual nature of many of these projects, neo-liberalism was still recognized as "an epochal shift" (Robinson, 1996a:24), an "immense political project [that] aims to create the conditions under which the 'theory' can be realized and can function" (Bourdieu, 1998:2) and, at a more organic level, "a reversal in ordinary common sense" (Hall, 1988a:164). In Ontario, the shift was called the "common sense revolution", named after the election platform of the Progressive Conservative Party it brought to power. It was a revolution in the Gramscian sense of the word, starting as a "war of position", in which different social forces organize into a broad alliance with a common world view and forming an "historic bloc", but quickly losing its organic qualities and hitting a "crisis of authority" by the midpoint in its mandate.

\footnotetext{
1 See chapter 2 for definitions and a history of these two terms, which will emphasize that neoliberalism is a different ideological project from what we know in modern politics as "Liberal" and "liberalism".
} 
If there was any surprise in neo-liberalism, it was perhaps in the relative speed with which it managed to gain and maintain hold of the state electorally if not hegemonically in the face of sometimes massive resistance from political and social opposition. A new ideological system is not imposed, but constructed in political and economic struggle and each new system has its own character (Simon, 1982). This involves no less than a remaking of the common sense of the people (Hall, 1988a); therefore a massive project of persuasion is an integral part of a neo-liberal project in its hegemonic journey. 'Persuasion' involved a massive project of intellectual reconstruction that was always present during the post-war compromise, but really took flight in the 1970s and 1980s when Western economies stalled (George, 1997). This task of persuasion is bolstered by the changing relations of forces in political communication, where media conglomeration and political centralization combine to create the conditions for a concentration of power that serves the dominant hegemony (Golding, 1986, 1992). Even before gaining electoral power, a hegemonic project works to gain "consent" by building a bloc of interests into an alliance of sufficient strength to engage the existing hegemony in a war of position (Gramsci, 1971). For neo-liberal projects, this is made significantly easier given the ties of its supporters to the state's intellectual and political leadership. But hegemony is not a 'top down' proposition; it still requires a working through of ideology into and from public consciousness.

In order for this to happen, the neo-liberal project, when it has achieved political power electorally, employs communications processes to communicate and legitimate policies that privilege political elites and their ideological objectives, 
bolstered by media conglomerates, which share their corporate interests. Neoliberal communications "offensives" (Golding, 1992:507) or "blitzkriegs" (Easton, 1989a), as they have been called, typically accompany legislative initiatives by new, neo-liberal governments at the start of a Parliamentary mandate, but they also are evident in their significant policy changes such as privatization, restructuring and downsizing processes that do not rely solely or primarily on legislation.

The overall objective of neo-liberal communications offensives is to narrowly define the issues, close down debate and opposition, allowing policy initiatives to move quickly and, if possible, without notice through the legislative process in order to achieve legislative legitimacy (Easton, 1989b). The processes employed to communicate neo-liberal policies may seem merely to consist of standard, 'modern', sophisticated means of policy promotion, but this masks the other, hegemonic role of communications offensives: to support the transformation of the political economy and achieve legitimacy, or consent, for a neo-liberal polity. In this, the media are "an important arena of struggle" in which they "set the terms in which public discourse is structured and reflected... they play a strategic role in debates over public policy by structuring understanding and winning the popular consent that is at the heart of hegemony" (Knight, 1998:96). This process thus has an ideological purpose and a paradigm-shifting impact on the public sphere, the role of the media and the functioning of government which is highly dependent on the successful ability of the government to communicate both the substance and the message of its policies for change. 
As this thesis will demonstrate, neo-liberal communications offensives and other Ontario government efforts at legitimation transform the public sphere $e^{2}$ by narrowing public space, overriding democratic Parliamentary tradition and minimizing political opposition and non-partisan resistance. To some, this has a negative impact on democratic communication by reducing accountability mechanisms of government to the public and by limiting representational public debate. ${ }^{3}$ This is offset to some degree by the increased organization of the public in resistance against the neo-liberal government's tactics, albeit usually in isolated pockets of opposition bounded by sectoral and class or group interests. In addition, neo-liberal projects rely to various extents on a populism that is constructed discursively and steeped in an organic 'common sense.' Where there is public resistance, initial electoral success stands in for consent for the massive structural societal change carried out by neo-liberal governments. Throughout their mandates, neo-liberal governments construct and reconstruct wars of position in the form of shifting and varied alliances to support specific policy initiatives, bolstering the appearance of consent.

\footnotetext{
2 In discussions involving political communication, the term 'public sphere' refers to the public only, rather than Habermas' (1989) conception of it as a sphere of overlapping activity which would include, for instance, the media. As this thesis is about political communication, the term 'public sphere' as separate will be used here.

3 The advent of neo-liberalism has brought a renewed focus on the meaning of democracy and has turned democracy itself into a site of struggle (Hall, 1988:124). Participatory or 'deep' democracy is a system of decision making about public affairs in which citizens are directly involved.

Representative or 'thin' democracy, a pluralist model, is a system of political rule embracing elected 'officers' who undertake to 'represent' the interests and/or views of citizens, which puts limits on public participation and public citizenship (Atkinson 1994a:17; Held 1996:7; Parkland, 2000). These two versions of democracy and the tension between them will be evident in the active resistance of social groups and movements against the Ontario government and its narrowing of democratic space for the public to occupy (see chapters 4 and 5).
} 
The media are central to the modern political process and are a key component in constructing the neo-liberal hegemony. They are the "pre-eminent vehicles of communication through which the public participates in the democratic process" (Herman \& McChesney, 1997:3). They also are agents of legitimation for the purpose of constructing consent on behalf of the hegemonic interests of which they are part. Structural changes to the media brought by centralization of media power and commercialization create institutions that are accountable to advertisers and shareholders, rather than to the public interest. At the everyday level of news production, the normative processes employed by the media are constructed by economic and organizational constraints (Epstein, 1973) and further defined by processes that privilege political elites through primary definition of sources and accredited access (Hall et al, 1978). The communication blitzkrieg used in communicating neo-liberal policies manipulates and subverts the media within a relationship that is also mutually reinforcing, as the media manipulate and subvert while also reinforcing the legitimacy of the state. In addition, one of the many contradictions in constructing and communicating neo-liberalism lies in the preference of neo-liberal governments, with their reliance on a common-sensical populism, to bypass the advantages of relying on the media and 'speak' directly to the public (Hall, 1988a).

The functioning of government also is transformed under the drive to establish and consolidate the neo-liberal project. Apart from any neo-liberal agenda, the work of a public service is increasingly politicized as it fulfills the explicit and implicit demands of a governing party (Tiffen, 1989). A government 
with a specific agenda for massive change uses the public service as a broker to develop, implement and communicate policy initiatives. In the case of a neo-liberal project in government, this takes place under conditions where the government is also seeking to downsize the state bureaucracy and, as a consequence, alter the public's experience and expectations of government. Changes to legislative procedures and public consultations are also intended to narrow public debate. The neo-liberal imperative of downsizing shifts public services (and jobs) to the private sector and leads to the creation of new forms of quasi-public government. These are influential to public policy while appearing to be nonpartisan and non-ideological and while operating without full accountability to the public (Deacon \& Monk, 2000). Representing themselves as anti-statist and decentralizing, neo-liberal governments instead have implemented stronger and more centralized government (Golding, 1986). Any decentralization they do implement does not shift power, except to other elites, and power structures do not change (Hall, 1988; Ralph et al, 1997).

The neo-liberal hegemonic project follows a legislative, policy and communications model or pattern that is historically constituted and structured. Each manifestation of the pattern is also specific, constructed by a combination of conditions unique to the country, but with commonalities in the 'basket' of neoliberal strategies (Williamson, 1994). Canada follows the successful model laid out in other jurisdictions, but also deviates from it due to public environmental conditions particular to Canadian political history and the Canadian political system (Clarke et al, 1996). 
Conditions that can have an impact on the execution of a neo-liberal project include: the development and state of the individual country's economy; the stage the neo-liberal project is in (which speaks to the ideological commitment to it and the amount of opposition it generates); the class-based nature of the opposition; social cohesion and the organization of resistance and contestation; media concentration and ownership; and mediation of neo-liberal views by the media. A common factor and starting point in the construction of neo-liberalism is the communication of a 'crisis' in the polity that can only be fixed by the transformation of society (Hall et al, 1978). ${ }^{4}$ The concept of crisis has been used differentially and uncritically with great effect, as has the discursive strategy know as TINA ("there is no alternative").

Crisis in an existing polity is a critical moment for the reconstitution of social forces and social authority. Bradford (1999) writes that moments of economic crisis and policy failure are "critical junctures in a country's history when consensus collapses, interests become uncertain, and there is considerable openness about future directions" and as "decisive episodes when political allegiances become decidedly fluid and policy outcomes highly contingent" (21).

\footnotetext{
4 To Gramsci (1971), crisis is the "certain point in their historical lives [when] social classes become detached from their traditional parties" (210). This is a "crisis of authority", also called the "crisis of hegemony" or the "general crisis of the state" (210). The crisis can either be conjunctural or organic. A conjunctural crisis is a current situation that requires a defensive, tactical response, is resolved, but is likely to recur. An organic crisis is a deep crisis that involves "a struggle to create a new balance of political forces, requiring a reshaping of state institutions as well as the formation of new ideologies" (Simon, 1982:38). A crisis is not an immediate event, but a process or a shift in the economic and political distribution of power (Gill, 1988:49). It can last for a long time, and can be resolved in different ways (Hall, 1988:167). In the short-term, most advanced capitalist states are resilient to immediate economic and social crises and can adjust and accommodate them as needed (Habermas, 1973:75; Gill 1988:44; Jenson, 1989:73; Kelsey 1994:182).
} 
The New Right has skillfully used the threat of economic and moral crisis in society and has even manufactured crises in order to build "the necessary and sufficient conditions" (Gramsci, 1971:178) to begin to shift ideologies and build a new hegemony or common sense. An adjunct to the construction of crisis is the "hit hard, hit fast, don't blink' tactics of implementation employed by neo-liberal governments, following New Zealand's successful use of the blitzkrieg (Douglas, 1993:ch. 10). Each of the three case studies, as we will see in chapter 4, relied on swift implementation in order to reach economic targets and deadlines set arbitrarily by the government for implementing its project.

The New Right's politics can be seen to be hegemonic in its pursuit of both economic and social long-term dominance. Gramsci's concept of hegemony can provide a framework to analyze how neo-liberalism took hold in Great Britain, New Zealand, Canada and provinces like Alberta and Ontario (and, in 2001, British Columbia), how it continues to maintain its power in the face of substantial resistance and how counter-hegemony might build conditions for a post-neo-liberal polity.

But there are limits to ideological dominance. Even with an ongoing consolidation of hegemonic forces behind it, there are interruptions in the process that suggest that government communications efforts at neo-liberal legitimation are not sufficient in themselves to ensure ideological success (Golding, 1992). These interruptions in the neo-liberal policy and legislative process can demonstrate how ideological power is not limitless, but contested. This supports Gramsci's view of 
hegemony as a field of struggle upon which battles and their outcomes are not inevitable, but are both won and lost.

Neo-liberalism has made major inroads into undermining the previous Keynesian consensus that was forged after World War II and is quickly becoming the new orthodoxy, both in Western industrialized nations and, through structural adjustment policies, in majority world countries. As the neo-liberal project restructures society and breaks down the collective structures and ideology of the welfare state into market individualism (Bourdieu, 1998), the task for any counterhegemonic project becomes more difficult.

\section{Thesis Statement}

This dissertation will demonstrate that communication is a vital, determining element in the successful construction of neo-liberal projects and new political realities. The neo-liberal project makes use of the power of the ideological reproduction of communication to achieve social transformation. It strategically ${ }^{5}$ employs communications processes to communicate and legitimate policies that privilege political elites and their ideological objectives at the expense of democratic communication and a healthy public sphere. It requires the persuasive power of communications to construct discourses that support the transformation of state economic relations. In the course of gaining consent and establishing

\footnotetext{
5 In this thesis, 'strategic' when applied to communication means the intentional and selective management of legitimation processes with the goal of furthering an ideological and political agenda. 'Strategic' can refer to both the vision and direction of the agenda and the operational tactics to support the strategic direction.
} 
hegemony, it both relies on and subverts normative media operations and government communications.

Through several case studies centred on the neo-liberal government that came to power in 1995 in Ontario, this thesis will examine how communications and other processes construct the neo-liberal project in this jurisdiction in Canada; provide a political-economic history of the development of neo-liberalism; demonstrate its impact on the public sphere, media and government; probe the extent and limits of the project; and suggest how democratic opposition is fostered that may eventually lead to a renewed consensus and a post-neo-liberal polity.

Using Gramscian hegemonic theory, this thesis demonstrates:

- how conditions are constructed under which neo-liberalism gains political and ideological space;

- how neo-liberal governments in general and the Ontario government in particular maintain hegemony despite ongoing resistance;

- how communications processes aid in constructing and maintaining the Ontario neo-liberal project; and

- the implications for democratic communication and the possibilities for the development of a new, post-neo-liberal polity through counter-hegemony that includes communicative democracy.

As in Scott (1997:11), underlying questions are also addressed: "Who is constructing political realities and what are their interests in the issues at stake? What strategies are used by certain groups or actors to set the terms of debate against oppositional views and tactics?" 
The thesis briefly examines neo-liberal projects in Great Britain and New Zealand, but primarily uses the example and experience of Ontario to illustrate the characteristics of neo-liberal projects in general and, specifically, the application of the project in this jurisdiction. Three case studies centred on the first, transitional phase of the neo-liberal project in Ontario support the contention that there is a general pattern to neo-liberal projects and, yet, that each jurisdiction constructs a neo-liberal project differently.

Resistance will be examined in the light of Williams's (1977:113) admonition that "any hegemonic process must be especially alert and responsive to the alternatives and opposition which question or threaten its dominance." Particularly in the case studies, it will be clear that the categories of "alternative" (contestation within society's norms) and "oppositional" (contestation outside the norms) shift in meaning according to how they are framed as resistance by the government. ${ }^{6}$ In the light of contestation of the Ontario hegemony and the fact that this thesis focuses on the transitional ${ }^{7}$ period in the emergent hegemony, this thesis will also examine how and when hegemony can be declared to have been achieved. Gramscian hegemonic theory is well-suited to the exploration of these issues. It theorizes civil society as the site of political and ideological struggle, as

\footnotetext{
6 The terms 'alternative' and 'oppositional' can be problematic. In North America, they are often reversed from Williams's usage so that 'alternative' refers to "serious challenges to the hegemonic order" and 'oppositional' refers to "political and not ideological conflicts between elites" (Karim, 1993:193). This thesis will use Williams's definition, since it is taken up by Gitlin (1980) in a context that is useful to this thesis. When the word 'opposition' is used in this thesis, it refers to general resistance or challenge that can be either or both 'alternative' and 'oppositional'.

7 The word 'transition' will be used in this thesis to describe the initial period following the electoral victory of a political party which espouses a paradigm-changing policy program. In Ontario, this is the period between June 1995 and December 1997. This is not to be confused with White's (1997:139) more general use of the term as "a party's taking over the levers of power and getting into a position to make decisions".
} 
well as the site of the exercise of intellectual and moral leadership for the purpose of gaining consent. By interrogating the interaction and interdependence of the economic, political, cultural spheres in society, hegemonic theory rethinks and extends issues of significance to political theory and, for the purposes of this thesis, the social and economic relations and issues that construct neo-liberal hegemonic projects: human agency, coercion and consent, institutional and other power relations, common sense and ideology, crisis, democracy and the public sphere. There are several ways in which the role of communication in constructing neo-liberalism is relevant terrain for analysis. They include: the need to make sense theoretically of this epochal shift; the absence of communication as a subject of analysis in neo-liberalism; and the Ontario experience of neo-liberalism as new analytical terrain.

First, in the same way that Gramsci's rethinking of Marx's theories was a response to political events of the times, theorists and other social actors will want to make sense of the fundamental shift that is occurring in how capitalist democracies govern: "The collapse of the Keynesian compromise renewed basic conflict and debate over the role of the state in the economy and appropriate public policy goals and instruments. Facing such uncertainty, a wide range of policy actors has sought new frameworks to interpret changing conditions and guide strategic action" (Bradford, 1999:17). Moments of breakdown and instability in systems provide opportunities for reconsideration and reorientation on both theoretical and practical policy levels. 
Where once socialism was on the rise in the post-World War II era, the fall of the Soviet Union and the failure of socialist governments in countries such as Britain or as close as the social democratic government of the NDP in Ontario in 1990-95 has discredited Left ideologies. ${ }^{8}$ When Keynesian economic policy was seen to falter, the organized Right was prepared and able to reconstitute itself (Girvan, 1994), while the organized Left was not able to offer an alternative intellectual or political vision (Hall, 1988a; Jesson et al, 1988; Laxer, 1996).

If politicians of any stripe aim to develop alternatives to neo-liberalism in a counter-hegemonic project of intellectual depth and vision, they will need to reclaim and restructure the terms of the debate from the Right before it further consolidates and solidifies its hegemonic position: "[T]he success of the libertarian right has depended on its hegemony, on its ability to set the terms of political debate. The success of a political opposition depends equally on its ability to shake this intellectual dominance" (Jesson, Ross \& Spoonley, 1988:117-8). Levitas (1986) also speaks to the fragility and instability of a new paradigm. Although writing in 1986, her comments about not conceding too much ground to the coalescing hegemonic alliance at the beginning of its hegemonic project or overlooking its intellectual inconsistencies are instructive.

Many see the challenge as to "impose some intellectual order on the confusion that surrounds us" (Jesson et al, 1988:29) and develop a new vision that can lead to a "novel and innovative hegemony" (Ransome, 1992:25). Although

8 In this thesis, the terms 'Right' and 'Left' will be used broadly, understanding that these terms cover wide ideological ground and that this approach may create a lack of clarity. At the same time, it should be relatively clear that social democracy is included in the Left, as in the statement in this text. In addition, neo-liberal politics, as we shall see, fan political polarization that makes these terms easier to interpret. 
there is always space in a hegemony for contestation (the concept in itself implies the existence of a counter-hegemony), there can be no return to a pre-neo-liberal state; instead a new intellectual project, born out of the current political circumstances, will need to be constructed (Kelsey, 1999). There have now been two decades of not just economic crisis but popular discontent and many of the taken-for-granted social aspects of the Keynesian welfare state-social movements, democracy, public sphere-will need to be re-examined in addition to economic theories before a counter-hegemonic project can develop (Bradford, 1999).

Some academics take the view that the current circumstances of economic crisis and restructuring have had a positive impact on radical political economy, in the sense that the often exclusive focus of political economy on the state and its apparatuses has now shifted "towards the representation of interests and the mobilization of political actors in different economic circumstances" (Jenson, 1989:70). Benefits to a radical political economy include better linkages between political economy and politics in Canada, as well as between Canada and other countries. For instance, Ransome (1992) believes that intellectual rethinking on the Left in response to neo-liberalism can give "new breath" to Marxism that can be applied to contemporary political development and create a new Left orthodoxy, much the same as Gramsci's project amplified understandings of Marxism as social transformation.

A second area of theoretical interest is to address the absence of analysis on the role of communications in constructing neo-liberal projects. Even the seminal textbook on market reforms emanating from the Washington consensus 
refers to communications only briefly and then only to indicate that research on the different countries that had experienced market reform "did not reveal much systematic attempt to make the case for reform in the media" and that it "would be a mistake to expect too much from an ability to build support through use of the media" (Williamson, 1994:586-587).

Yet, as "one of the new superstructural elements that are important for meaning formation" (Ransome, 1992:5), communications industries are a key creator and carrier of ideological legitimation in their role as persuader. Legitimation is an ongoing commodity. It requires constant stimulation and reinforcement. Social actors "depend for their influence on their ability to contribute to the institutionalization of... meaning systems" (Jenson, 1989:74) and communications provides the primary terrain upon which this is produced and reproduced for consumption. Neo-liberal projects are highly dependent on the power of elite interconnectedness and influence; communications provides fertile ground for examining concretely the linkages between these projects and communications institutions, the public relations industry and public opinion research companies as "captains of consciousness" (Ewen, 1976).

Lastly, the study of the role of communication in constructing neo-liberal projects is relevant because Ontario's experience is relatively new analytical terrain. At this stage of the project—eight years and two elections old-there is a sufficient body of information, documentation and experience to allow for analysis, yet the project is also sufficiently new so that its ongoing progress can be monitored. 
Ontario's experience of neo-liberalism raises an interesting jurisdictional issue not seen in neo-liberal projects in other non-Canadian jurisdictions. Ontario is Canada's most populous province, contains two seats of government (Ottawa and Toronto) within its borders, is located centrally and is the country's "traditional industrial heartland" (Bradford, 1998:540). Although the centre of most Canadian political, cultural, social and economic activity, it is still contained within the dominion of Canada - a state which has chosen a different, less radical way of achieving neo-liberal goals, but is nonetheless a carrier of neo-liberalism. ${ }^{9}$ It would be natural for Ontario to absorb the impacts of international and national shifts early and there is a question of how these projects and their component policies might pre-condition the Ontario environment for the introduction of neo-liberalism, for instance, through discourse on debt (Klein, 1996). In addition, the Canadian federation is decentralized with considerable power in the regions. Its hegemony is relatively weak, compared to other states and thus more absorbent of environmental shifts.

Ontario is significant as an example of 'Canadian-made' neo-liberalism that can be examined through the lens of hegemonic theory. Hegemonic theory by its nature demands a separate analysis of this new manifestation of neo-liberalism; we can learn from accounts from other jurisdictions, but we must be open to understanding the historical and political specificity of the Ontario example. Thus, there is a need to connect the 'big picture' theory to specific case studies in Ontario

9 Canada's "stealth" approach to neo-liberal policies will be examined in chapter 2. 
that can better illustrate how social transformation and ideological reformulation take place.

\section{Gramsci's Theory of Hegemony}

Gramscian hegemonic theory is a rethinking of the early interpretation of Marxism that believed capitalism would move inevitably to crisis and collapse. Instead, it recognizes that "the outcome of any economic crisis depends on the conscious actions of human forces, that is, on political intervention" (Simon, 1982:14). With this in mind, Gramsci re-evaluated the significance of the superstructures of society, positing them as the location where perceptions are shaped and consciousness is raised (Adamson, 1980:216), and attributing new importance to politics and political activity. He stressed a dialectic of social change that combined agency and structure, and he synthesized interaction between material and ideological forces (Gill, 1988:230-1), identifying "points of fissure, contradiction and change" (Parkland, 2000:11). His concept of hegemony is "a point of intersection... where culture, ideology, totality, intellectual, revolution, and political education dialectic are brought into material rapport" (Adamson, 1980:176), while maintaining "the commitment to the project of socialist transformation that distinguishes Marxism as a living theory, an open-ended project of critical thought, without guarantees" (Hall, 1988:131). 
Gramsci also theorized a greatly expanded concept of politics, ${ }^{10}$ which contributes to an understanding of partisan politics and the "moving consensus" that constitutes it (Gamble, 1993:201). Since his conceptualization of politics was based on the precept of social transformation, he also demonstrated how hegemony requires a broader political base. To do this, he elaborated on a series of concepts which are "crucial to the theory of politics" (Mouffe, 1979:4): hegemony, civil society, consent, passive revolution, historic bloc, role of intellectuals and war of position.

Hegemony itself can be a slippery and inexact concept (Jessop, 1990; Hall, 1985, 1988) and Gramsci himself uses the term in different ways (Ransome, 1992:7). Hegemony has been described as "a force of domination exercised though civil society" (Robinson, 1996a:39) and although "domination" is commonly used to define hegemony, it may be too narrow to encompass the active sense of the concept and the duality of coercion and consent that constitutes it. It is perhaps more clear to think of hegemony as a relation, "not of domination by means of force, but of consent by means of political and ideological leadership" (Simon, $1982: 21)$. As a general definition, we can think of hegemony as "the process by

10 Gramsci's concept of politics "covers any activities which are intended to change the nature of the spontaneous consent which has been built up in civil society" (Simon, 1982:89). Politics, in fact, was understood by Gramsci as "the first, last, and mediating moment of reality" (S. Golding, 1992:127). This emphasis on politics is situated within "a process of becoming" (128) that extends to the human activity involved in the struggle. Politics is then also a site for human agency and transformation of civil society (Simon, 1982:92). The shift to neo-liberalism has created new sites of antagonism and resistance-new "constituencies" that might be catalytic in the development of an "expanded, multifaceted and hegemonic conception of politics as a "war of position." The possibilities for the politics of the future, however, are at the same time hampered by the difficulty in constructing a cohesive and unified counter-hegemonic progressive force (Hall \& Jacques, 1988:17). Just as social movements politicize what was formerly not political, neo-liberalism depoliticizes, by contending that competing claims represent "special interests" and not what is good for the state (Harder, 1996:37). The contestation for political space will be evident in the case studies in chapters 4 and 5. 
which groups in society attempt to establish their power through exercising political, intellectual and moral leadership... it is established primarily by seeking and gaining the active consent of individuals to particular views" (Jesson et al, 1988:5). More succinctly, "hegemony is the political and ideological organization of consent" (Patten, 1996:99).

One of the inherent qualities of hegemony is its sense as an active, ongoing process of continuous creation rather than as a fixed state (Adamson, 1980: 174). It is neither an act of will nor predetermined, but an "exploration of interaction between agency and structure" (Gamble, 1990:211). There is thus an inherent tension in the construction of a new hegemony between it and the existing hegemony. Hegemony is constructed on multiple sites of struggle and resistance, much of it focused on undermining consent and attaining an alternative (Adamson, 1980:170-1). This is made more difficult as "the structures of the modern state and society complexify and social antagonisms proliferate" (Hall, 1988:168). An existing hegemony is in perpetual conflict with the next hegemony, as there is no moment of completion or securement: "The concept of hegemony is not about imposing ideas on subordinate groups, but describes a process of negotiation with opposing classes and values which often involve genuine compromises by dominant groups. Although some groups have greater access to ideological resources, their cultural leadership is never completely secured" (Parkland, 2000:11).

Gramsci insists on historical specificity in his analysis at the same time as he stresses continuity with the past (Simon, 1985:64). When he advocates a transformation of existing ideologies, for instance, these shifts are not a substitution, 
but a rearrangement into a distinctive new system (Hall, 1988: 158). His approach, according to Hall (1988) is to ascertain what is specific and different about the particular moment or historical conjuncture, "how forces come together, conjuncturally, to create the new terrain on which a different politics must form up" (156).

Gramsci provides us with a theory of society in which hegemony is constructed and played out in a particular way. He conceives of a network of social relations and the institutions and organizations (political parties, unions, and mass media) which constitute it as the civil society. A separate set of institutions and apparatuses along with the relations of production comprises 'political society' or the state (Gramsci, 1971:12). Hegemony is exercised in consensual relations through civil society and is the sphere of struggle. Political society refers only to the coercive relations in state apparatuses and thus exercises coercive power (Simon, 1985:26, 70). When Gramsci speaks of the state, he is referring to "political society + civil society, in other words, hegemony protected by the armour of coercion" (Gramsci, 1971:263). Thus civil society contains a duality: separate from the state, it could create an alternative hegemony from the state; linked to the state, it could have political ramifications on the state (Adamson, 1980:215). Hall et al (1977:47) clarify what they call Gramsci's "elusive" sense of civil society as including:

not only associations and organizations like political parties and the press, but also the family, which combines ideological and economic functions... Civil society, then, in Gramsci's words, "stands between the economic structure and the state... [C]ivil society is the terrain in which classes contest for power (economic, political and ideological). It is here that hegemony is exercised..." 
This is important to clarify as it reveals more clearly where ideology is formed and on what ground ideological struggle takes place.

Gramsci also contrasts his own conception of civil society with that of liberalism. Liberalism maintains a strict separation between civil society and political society, while Gramsci theorizes the two as comprising "a historical dialectical totality" (Augelli \& Murphy, 1988:132). To Gramsci (1971:160), liberalism's laissez-faire is itself a deliberate political program and "a form of State 'regulation', introduced and maintained by legislative and coercive means." Gramsci's concept of consent within a consent-coercion duality is key to understanding how hegemony is constructed politically and ideologically. A class or its representatives exercise power over subordinate classes by a combination of consent and coercion or force, which is integral to the operation of the state (Simon, 1985:21). Consent is not easily given. It is active and negotiated by unequal forces (the dominant class over subordinate classes), yet appears to be spontaneous (Gramsci, 1971:12). Not only is consent "very demanding", but the very need for it implies resistance and possibilities for change (Mosco, 1996:243). A hegemony under development, that is, seeking consent, is uneven and vulnerable and open to antagonism and negotiation (Adamson, 1980:174; Ransome, 1992:22). When a hegemony is 'achieved', the state's coercion remains latent, but when consensus breaks down in periods of crisis, its coercion becomes active (Robinson, 1996:359). If the hegemony is seriously under threat-undergoing a "crisis of authority" (Gramsci, 1971:210)_available resources for legitimation can be pulled into play (Habermas, 1975:70). 
Gramsci developed the concept of historic bloc to demonstrate how groups or classes gain hegemony. A class or group must achieve leadership in both political society (the sphere of economic production) and in the social forces of civil society - the base and the superstructure (Simon, 1985:26). When a group or class combines leadership in both spheres, which in any case are already "interpenetrated", it becomes a historic bloc in a "dialectical unity" and the group or class is seen as hegemonic (Augelli \& Murphy, 1988:7). To accomplish this, it must build a system of alliances that go beyond its own narrow and immediate corporate interests (Gramsci, 1971:77) by moving from the level of attachments with like-minded others, referred to as the "economic-corporatist" phase, through a phase ("solidarity of interests") in which it finds solidarity with other groups to the third level or phase of stabilized relations between economic and political-cultural life, in other words, to consciousness and solidarity, the "unison of economic and political aims" phase (Gramsci, 1971:181). Gramsci describes this process, which is critical to his theory, as moments or levels in "relations of force." Once a historic bloc is formed, which occurs at the hegemonic level of unison, the groups or classes within it can "effectively exercise state power, whether directly or indirectly" (Robinson, 1996a:28). The historic bloc does not need to actually hold state power in order to exercise it.

This is an important moment in the quest for hegemony. It implies that organized forces that are not part of the formal apparatuses of the state (and, in modern terms, do not hold electoral office) can be influential and can act on their exerted influence. In fact, it can be said that once a historic bloc is formed, it needs 
legitimation to be maintained and extended, so it must rely on the ability of its members to persuade and organize the necessary consent. This process of becoming "the national representative of a broad bloc of social forces" is not uncontested, but part of a struggle in which each of the different forces "strives to strengthen its own pattern of alliances, to disorganize the alliances of the other, and to shift the balance of forces in its favour" (Simon, 1982:23). It is the role of intellectuals to show leadership in the creation of the historic bloc and to maintain its alliances through its support at the ideological level. To do this, they must organize, produce and articulate the hegemony (Gill, 1988:51), ultimately "inculcating other intellectuals with the dominant worldview, and assimilating them" (Augelli \& Murphy, 1988:123-4). The task of the intellectuals is two-fold. They must tear down the "common sense" " of the people-the "the uncritical and largely unconscious way in which a person perceives the world, often confused and contradictory, and compounded by folklore, myths and popular experience" (Simon, 1982:25). Then they must enable people to build a more coherent outlook that Gramsci called 'good sense' (1971:328). This a challenging task, as good sense must be formed

\footnotetext{
11 Common sense is the "uncritical and largely unconscious way in which a person perceives the world, often confused and contradictory, and compounded of folklore, myths and popular experience" (Simon, 1980:25). It is shaped out of ordinary, practical experience and appears 'natural' and 'taken for granted' (Hall, 1988:8). Common sense may appear to be transhistorical, but "there is not just one common sense, for that too is a product of history and a part of the historical process" (Gramsci, 1971:325-326). Gramsci saw the revolutionary struggle as centred within the transformation of common sense into 'good sense.' Common sense can only be raised to the level of coherence or good sense through a political intervention from organic intellectuals (Hall, 1988:142) that liberates its contradictory consciousness (the naturally lived ideologies and the consciousness of current society) and develops its core of good sense (Augelli \& Murphy, 1988:21). The role of the intellectuals is to "order and form the mass consciousness as common sense so as to make it a revolutionary force" (Abercrombie, 1980:73). In Ontario, the phrase "common sense" stands in for the ideology of neo-liberalism, especially when tied to the Conservative banner of "common sense revolution'.
} 
organically and the critical understanding of self that it enables only develops through struggle (333). Neo-liberal governments in Great Britain and Ontario have put a twist on the phrase "common sense" by both explicitly and implicitly referring to it in the symbolic aspects of their political practices. The case studies in chapter 4 examine the "common sense revolution" of the Ontario neo-liberal government and will shed some light on its common-sense aspects in message production. One additional concept-the war of position — in Gramsci's theory of hegemony has resonance in this thesis. Gramsci theorized that there were two political strategies that would lead equally well to revolution. The first was the 'war of movement' that Russia had experienced with its high concentration of state power and its capture in a single historical moment (Simon, 1982:28). The second was a 'war of position' that operated by different social forces organizing into a broad alliance with a common worldview. The alliance slowly expands its hegemony, building in effect a historic bloc at the same time that it transforms the state (Simon 1982:28). Gramsci's war of position is a dynamic concept that can be applied to social and political movements and is especially useful in situations in which dramatic political change occurs that is unforeseen. This can apply to Great Britain in 1979 and to Ontario in 1995.

The war-of-position thesis involves another political strategy that helps build the chances for a successful change-over in power. In complex societies, where civil society has developed an advanced "system of fortresses and outworks" (Gramsci, 1971:238), it becomes increasingly difficult to win even a war of position. Gramsci recommends that one of the principal conditions for the winning 
of power is for groups or classes to gain intellectual hegemony prior to winning government power (Gramsci 1971:57-8). This they do by developing their own leadership - "the organic intellectuals"-and winning over traditional intellectuals from the existing ruling hegemony (Hall et al, 1977:51).

In sum, Gramsci's theory of hegemony is an approach that lends itself well to historical explanation and analysis as a "struggle to gain ascendancy over a whole form of social formation, to achieve positions of leadership in a number of different sites of social life at once, to achieve the commanding position on a broad strategic front” (Hall, 1977:128).

\section{'Achieving' Hegemony}

An unresolved question for those who examine the modern expression of neoliberalism through a Gramscian perspective is to come to an understanding of when a hegemony can be considered achieved. A succinct Gramsican answer might be "never", as a hegemony to some degree is always in a state of flux. Abercrombie (1980:118), for instance, suggests that hegemony can never be complete because the subordinate classes do not give their consent wholeheartedly, although neither may they be resisting. Or there are general notions, such as "when a class or group of classes exercises control over both state and civil society" (Klein, 1996:15). ${ }^{12}$ There

\footnotetext{
12 Gramsci's conception of class, while anchored in initial economic relations, recognizes that class interests "are not given but have to be politically and ideologically constructed" (Hall, 1988:167). To Gramsci, class is a social group that shares the same world view and an individual within a social group can share features with different classes. Although each group originally arises through the role it plays in economic production, other factors then intervene and help shape the individual's world view (Nemeth, 1980:87). There are two developments in class relations that are of interest to this thesis: the rise of the middle class as a political and social force (in Ontario, the middle class did not radicalize until its members began to feel the erosion of their quality of life through the policies
} 
have, however, been more extensive attempts to understand with more theoretical rigour how a successful hegemony is constituted, particularly in political systems that tend to see electoral victory as equated to hegemony. Gramsci (1971) himself sets some criteria, starting with ability to lead and prior ideological supremacy. "A social group can", he says, "and must, have already exercised 'leadership' before winning governmental power (this indeed is one of the principal conditions for the winning of such power); it subsequently becomes dominant when it exercises power, but even if it holds it firmly in its grasp, it must continue to 'lead' as well"' $(57-8)$.

Hall's (1985:17) early assessments of Thatcherism led to his posing three critical questions to determine whether a hegemonic project is successful: "Can it lead the key sectors? Can it win the strategic engagements? Can it stay in front when challenged?" Jessop et al (1988) and Gamble (1993) rejected these criteria, Jessop on the grounds that Hall was mistaking domination for hegemony. Jessop et al's (1988) sole criterion linked success to economic success: "Ultimately, the success or failure of such a hegemonic project is dependent on the capacity of the accumulation strategy to continue to provide economic growth" (180). Gamble (1993) divided hegemony into four dimensions -electoral, ideological, economic and state-and analyzed each separately, concluding that Thatcherism had not achieved hegemony except for a fleeting economic hegemony. Robinson (1996a), referring to the international uses of neo-liberalism, views neo-liberal hegemonic

of the new government); and cross-class alliances forged as a political strategy. Middle-class radicalism and cross-class alliances will be features of the Ontario-based case studies to be discussed in chapter 4. 
success as the absence of democracy: "Success is not measured only by the stabilization of consensual forms of domination. It is also measured by the extent to which projects of popular democracy were suppressed" (138).

The debate about hegemonic success is dominated by British theorists and commentators (Riddell, 1983; Hall, 1985, 1988; King, 1987; Jessop et al, 1988; Hall \& Jacques, 1984, 1989; Gamble, 1993). This may be an indication that the debate is limited to the particular historical project of Thatcherism, which was the initial large-scale neo-liberal success in an industrialized country and that revealed dramatically a radical shift in the polity. But it cannot be discounted that jurisdictions that experienced neo-liberalism later than Great Britain might some day cover the same terrain. It also reveals perhaps less about hegemony than it does about different theoretical approaches. Jessop et al's insistence on assessing changes to accumulation strategy reveals a concrete but narrow economic criterion for success (the viability of an accumulation strategy) which is reflected in the economic imperative of neo-liberalism itself. Hall, on the other hand, emphasizes changing and contested socio-cultural relations.

Jessop's (1983:104) unique contribution to understanding hegemony and its success lies in his categorization of hegemonic projects on a continuum between an expansive (or "one nation") project through various forms of "passive revolution" to an open "war of manoeuvre" (or movement). In other words, hegemonic projects take many forms along a continuum in which the state reorganizes social relations while neutralizing and containing popular initiatives from below (105). The hegemonic projects on the continuum are in dynamic 
movement between the consensual, inclusive and unified hegemonic project (at its strongest in the form of Keynesianism) at one end of the continuum and the coercive aggression of the war of movement at the other end. This thesis will consider the possibility that the Harris pre-election war of position may have lost its organic qualities and may be only a weak and transitional form of hegemony.

In Canadian scholarship, McBride (1992) takes the position that the emergent hegemonic fraction must demonstrate political and intellectual leadership. In practice, the aspiring hegemon must show it can organize and lead its allies, and it must have established an ideological base. At the level of ideas, $\mathrm{McBride}$ recognizes the need for "persuasion and organizing of consent" of subordinate groups and classes by the intellectuals as a central aspect of hegemonic rule (21-2). This meets Gramsci's criterion of intellectual leadership. At the material level, hegemonic rule takes into account and combines the interests of other groups and clasșes with its own interests, thereby meeting Gramsci's criterion of political leadership.

Finally, McBride draws attention to an important consideration regarding hegemonic success. Once a hegemony is successfully established, it "is virtually unnoticed in everyday political, cultural, and economic life" (22). In other words, a hegemony is successful when it becomes stripped of ideology and appears natural, as common sense, which returns our attention to the "ideological and symbolic state activities" (20) that are instrumental in the construction of neo-liberalism. By this consideration, and as the case studies will show, the Harris hegemonic project 
during the transitional time-frame under examination here was still immersed visibly in ideological struggle and may not yet have 'achieved' hegemony.

\section{Gramsci's Limitations}

Gramsci's theory of hegemony and his related writings have not been accepted uncritically. Harris (1992:20) contends Gramsci's work became popularized as a "congenial" Marxism, one that was "theoretically respectable, non-reductionist, and optimistically activist." Some question Gramsci's place in Marxism, believing Gramsci took it to a "critical breaking point" (Barrett, 1991:51) or rethought it entirely (S. Golding 1992:xii). Much of the criticism is related to frustration with Gramsci's coded terminology, which often resulted in confusing passages and interpretations, but there is "conceptual slippage" (Anderson, 1976:49) as well. For instance, as Anderson points out, Gramsci uses three definitions for "the state", as contrasting with, encompassing or identical with civil society (13).

More critically, Gramsci's concepts themselves have been criticized, such as "civil society", which appeared to be connected theoretically to Habermas's public sphere (Simon, 1982:92), thus seeming more of a bourgeois rather than a revolutionary concept (Harris, 1992:20). In defence of the "civil society" concept, an analysis from the Centre for Contemporary Cultural Studies, led by Hall et al (1977), suggested that this concept actually reflected Marx's early writings.

Gramsci has been sometimes charged with historicism, by virtue of basing his work on examples from history, reflecting his "preoccupation with the political, tactical and historical questions of the day", while such historical circumstances 
may no longer be relevant (Adamson, 1980:221). Harris (1992:20) suggests a reading of Gramsci as responses to specific political events rather than as general policies, a view that is shared by Anderson (1976).

Even the often-quoted passages on the balance of forces (Gramsci, 1971:179-82) have many interpretations, with Augelli and Murphy (1988), Gill (1988), S. Golding (1992) and Simon (1982) all characterizing the three levels differently. A critical issue that has arisen from interpretations of this passage is the instruction to combine interests, which begs the question of how groups can maintain ideological purity or-perhaps a lesser goal-a common conception of the world (24), if they make the compromises that Gramsci seems to be suggesting. To Jessop (1997:63), Gramsci puts too much emphasis on changing the balance, but ignores the "decisive underlying nucleus" (71), which is presumably economic. Gamble (1993:207-8) clarifies this dilemma by pointing to Gramsci's direction that the compromises should only be at the economic-corporate level (early in the process), which implies that hegemony must be economic in addition to its other aspects. Still, concerns persist that Gramsci does not advocate a revolutionary strategy so much as a reformist one, with his "war of position" not an alternative path to counter-hegemony, but to social democracy instead.

Lastly, in the critical area of group or class struggle, which is central to Gramsci's model (Harris, 1992:20), Tarrow (1998:12) charges that Gramsci has "no theory of political mobilization" and "no guide" to show how struggle is to take place. Here, Gramsci relies on organic intellectual leadership and the war of position to make his point. 
In short, Gramsci has been seen as both philistine and visionary. There is considerable frustration that his writing is fragmented, coded and all too short, yet it is doubtful that even if his work was complete, intellectual arguments would cease; perhaps that in itself signals the importance of his contribution as a critical thinker of "iconic significance for the contemporary left, both intellectual and cultural" (Barrett, 1991:51). His contribution lies in his acknowledged areas of strength: the concept of hegemony itself and its emphasis on process, the concept of civil society working as the sphere of struggles in a contest for hegemony, his focus on human agency and cultural/intellectual practice, and problematizing of common sense and crisis.

\section{Theoretical Approach}

As delineated by Mosco (1996), this thesis takes a realist approach, addressing both theoretical and interpretive considerations as "multiply determined and mutually constitutive" (Mosco, 1996:3). Its approach is inclusive and open, in that it does not assume that one theory encompasses knowledge or that it is even possible for one knowledge to be encompassed, but rather that a combination of approaches can illuminate both the constituent parts and the whole of this account of neo-liberalism. It is also guided by an approach that is critical in its understanding of the breadth and limits of a political economy approach, as well as an appreciation of a "conception of theoretical practice that sees intellectual work as a form of social intervention (praxis)" (Mosco, 1996:9). The centrality of praxis takes on particular significance for the subject of this thesis, which seeks to understand the conditions 
under which neo-liberalism has developed and explores the possibility of a socially transformative post-neo-liberal polity. A critical approach attempts "to overcome... the separation of theory and practice", it is context-bound and future-oriented (McCarthy, 1973:x-xi). This conception of theoretical practice is compatible with Gramsci's hegemonic theory, which is the approach underpinning this thesis. Further, it is also a personal aspiration that this work be accessible, in agreement with Anderson (1996:197) that "the business of scholarship... is to create meanings from which we can act."

The theoretical approach here draws on political economy as well as critical cultural studies in its examination of social relations, particularly power relations, that mutually constitute how the public sphere, the media and government relate to one another. Thus it gives weight to both the material and symbolic aspects of the neo-liberal project through critical analysis. Political economy in particular "aims to trouble and challenge conventional ways of framing issues" (Clement \& Vosko, 2003:xii), which is in keeping with this thesis's probe into alternative and oppositional meaning systems (Williams, 1977). An approach based on critical cultural studies and political economy is strong in the theoretical areas this thesis needs to address and has the necessary and sufficient explanatory power for an examination of neo-liberalism: a balance of both economic and social relations; a broad conception of power relations; recognition of the agency of social actors; ideological legitimation; and the changing role of the state. Within critical cultural studies and political economy, it will concentrate on the political and ideological dimension of neo-liberalism. 
This thesis relies on the strength of political economy in economic relations, recognizing the strength of that paradigm in analysis involving this sphere. This is not to contradict the position just expressed for not privileging one or the other of the economic or the social, but to point out that in neo-liberalism the market has iconic status, in fact "commitment to the market is the key mechanism of [its] economic and social regulation" (Held, 1986:2) and "economic policy continues to be the main feature of... influence" (Girvan, 1994:216). Using an approach that is theoretically grounded in both economic and social relations will help explain how the separation of economic from social relations is a neo-liberal construct that validates "an economic system conforming to its description in pure theory, that is a sort of logical machine that presents itself as a chain of constraint regulating economic agents" (Bourdieu, 1998:2). Critical cultural studies will come into play as an alternative vision of economic and social relations is explored, that is, that the economy is the sum total of human activity, not an external reality with a momentum of its own (Jesson, 1988).

Gramsci's position on the economic sphere of activity is that "economic aspects may provide a necessary level of determination, but they cannot provide the sufficient conditions" (Hall, 1988a:127). In other words, economic activity and crises don't produce historical events, they "simply create terrain more favourable to the dissemination of certain modes of thought, and certain ways of posing and resolving questions involving the entire subsequent development of rational life" (Gramsci, 1971:184). Changes to economic systems and other structural changes 
thus should be analyzed in the context of social forces, including interplay among different interests (Gill, 1988).

Political economy has a strong record of analyzing interests (power relations) and their interplay. By showing that interaction of social forces can help explain the historical process (Gill, 1988), Gramsci's contribution to the study of power relations is to situate power as a duality, that is, as both coercive and consensual (Simon, 1982:73). As a dialectic, the power duality implicitly acknowledges a tension among interests, which "are not given but always have to be politically and ideologically constructed" (Hall, 1988a:167). As such, power is a relation that is found not only in the coercive apparatuses of the state, as Marx theorized, but also diffused throughout civil society (Simon, 1982:27). Hegemony is thus about how power is exercised by both coercion and consent (persuasion) on the terrain of an "integral" state that encompasses civil and political society (73).

Since power implies resistance to power, power also shifts within Gramsci's balance of forces, particularly in times of crisis. Hegemonies are constructed in struggle and can lose their authority; they are "only historical constructions, which may be reproduced, changed or overturned as a result of human agency" (Jenson, 1989:75). In times of crisis of the state, power can take both material and symbolic forms: "At these moments of breakdown, there is good reason to claim... that ideas acquire extraordinary power in reorienting the course of public policy" (Bradford, 1999:17).

As will be demonstrated in chapters 2 and 3, neo-liberal restructuring will have consequences for counter-hegemonies that will have to build historic blocs 
from the many and varied sites in which power is constituted (Hall, 1988:164) and impacts on accountability of governments to citizens, as formerly public responsibilities move to the private sector.

Political economy's interest in agency was influenced by Gramsci, who linked agency and structure and reformulated them into a dialectic that includes social, ideological and cultural relations (Simon, 1982). Carroll and Coburn (2003:94) suggest that there is a "dialogical relation" between political economy and political agency, in that social movements employ the justice vocabulary of political economy that underlies counter-hegemonic politics, while political economy learns from movement activism and analysis (80). Cultural studies, also, appropriated Gramsci's views on hegemony and social relations (Mattelart \& Mattelart, 1996), which grounded agency within social structure (S. Golding, 1992). Cultural studies emphasizes interactivity amongst social actors and changing modes of representation, which allows it to explore previously static concepts such as 'class', 'ideology' and 'struggle.' All of these concepts have relevance to this thesis, as it explores how neo-liberal hegemonic projects are constructed by historic blocs or alliances of actors from different classes or social groupings, often under conditions of resistance.

Both political economy and cultural studies offer insights into how ideology is reproduced and maintained through ideological legitimation, an important aspect of Gramsci's theory. Gramsci doesn't reduce explanation to the economic level only or treat ideological dimensions either as secondary or as a single belief system, neither does he reduce ideology to one world view, but 
recognizes that ideology is multiply situated within social relations (Adamson, 1980). He "emphasizes the relationship of ideas to material interests, and examines the use of ideas to legitimize hegemonic programs" (Klein, 1996:14). This is a 'looser' view of ideology, more in keeping with Hall's (1986) definition as "the mental frameworks--the languages, the concepts, categories, imagery of thought, and the systems of representation-which different classes and social groups deploy in order to make sense of, define, figure out and render intelligible the way society works" (26).

Both political economy and critical cultural studies, but especially the latter, take a nuanced approach to ideological formation and legitimation that understands that "in order for new ideas to progress they must 'work on' interests to realign the policy goals of collective actors, and they must 'work through' organizations to transform policy-making routines and state capacities (Bradford, 1999:20). This approach recognizes that ideology is not given and unalterable, but open to reconstruction and recombination. Cultural studies also provides an extension of this work of recombination in its understanding of how discursive formations can aid in legitimation by, in the case of neo-liberalism, appropriating discourses from both moral conservatism and the Left (Davis, 1993; Phillips, 1996).

Political economy and critical cultural studies' capacity to contextualize analysis within social relations is also significant to this thesis. Conceptions of the role of the state within civil society continue to be theorized in the face of neoliberal restructuring, which challenges traditional conceptions of public and private spheres. For Gramsci, "the state is clearly absolutely central in articulating the 
different areas of contestation, the different points of antagonism, into a regime of rule" (Hall, 1998a:169).

In addition, neo-liberalism is a global phenomenon that is linked to international hegemonic strategies through intellectual and political networks of influence. Although Gramsci's theories were related to civil society at the national level, they are well-suited to application to the international level as well to explore how hegemony expands beyond the state. Just as economic globalization is ongoing, so social movements are internationalizing and it is thus important in developing viable alternatives of economic, political and cultural arrangements because any counter-hegemony must take into account the growth and power of international capital (Gill, 1988:47).

Within political economy and critical cultural studies approaches, this thesis will concentrate on the political and ideological dimensions of neo-liberalism. This allows for an amplified discussion of "how ideological transformation and political restructuring of this order are actually accomplished" (Hall, 1988a:56), and, further, locates the power to transform and restructure within civil society (Robinson, 1996). There is general recognition of the benefits of taking this approach. Beyond Hall $(1985,1988 \mathrm{a}, 1988 \mathrm{~b}, 1989)$, who first theorized it in relation to Thatcherism, Bourdieu (1998) reminds us that "the neo-liberal program draws its social power from the political and economic power of those whose interests it expresses" (2), and Ransome (1992:25) points out that "the business of dislocating the dominant group is seen as being principally located within the 
ideological and political realms." This is consistent with Gramsci's understanding of ideology as a political force, as well as a world view (Augelli \& Murphy, 1992). Moreover, a focus on the ideological-political dimension of neo-liberalism goes to the heart of its strategies, which are explicitly ideological and would require a counter-ideological strategy if there is a desire to defeat it politically: "The New Right has adopted an explicitly ideological strategy and has been successful in mobilizing at least sufficient support from a range of social groups to remain in power. Its political defeat requires an understanding of how the New Right has managed to do this, and how that process might be reversed" (Levitas, 1986:11). In particular, the concept of authoritarian populism ${ }^{13}$ - the common sense of the people that works in the interest of a particular ideological program-is one ideological strategy that helped construct a crisis that led to the Thatcher years in Great Britain and has since been applied in different jurisdictions (for instance, New Zealand, Alberta and Ontario) with local variations. Not only is authoritarian populism an important, linking thread from state to state in the current form of neoliberalism, it provides an explanation of how popular consent is manufactured. Other strategies of ideological formation include: the construction of an intellectual

\footnotetext{
13 Authoritarian populism is an "interpretive device" created by Hall (1988) to help explain the success of the Thatcher government in Great Britain: "It was popular because it drew upon popular discontent with many aspects of the social-democratic state to win support for a radical-right programme. It was authoritarian because in the implementation of its programme it further increased the central power of the state and weakened opposition to it" (Gamble, 1993:182). Hall (1988:50) recognized two streams within this populism that mirrored the two strands that comprise neoliberalism as an ideology-moral conservatism and market liberalism. He (1988:50) points out how authoritarian populism incorporates people's real and contradictory experience of living in the welfare state. Thus it is not just ideational, but has a rational core and a real material basis. To Hall, that is the moment of authoritarian populism - "simultaneously from 'above' (in the state) and 'below' (down there with the people)-with the net effect of constituting a new balance of forces" (169). Authoritarian populism is elaborated on in chapter 4.
} 
leadership; formation of a new stratum of "organic" intellectuals; and the level of organization of political ideas in certain strategic academic, research and other intellectual sites (Hall, 1988a). These strategies are also consistent with the approach used by Gramsci, which, as a theory of politics and agency, is at once political and ideological (Abercrombie et al, 1980:11).

But a singular focus on ideology can be dangerous, engendering charges of reducing ideology to an instrument of class (Simon, 1985) or to an idealist battle of ideas only (Levitas, 1986). This is one reason why any examination of ideology must take care not to de-emphasize economic and social contexts in which ideas and the interests that uphold them occur (Levitas, 1986). The 'trick' is to give sufficient emphasis to the role of ideology in the social process, but not to overstate it (Levitas, 1986). This is rendered more difficult because Gramsci does not delineate a systematic theory of ideology, instead emphasizing social struggle across social formations.

Gramsci challenges the borders of traditional notions of ideology and Marxism (Hall, 1988:130) and, in so doing, raises expectation of how to view critical theory (Gramsci would say as emancipatory) and how to engage in analysis of social relations (Gramsci would say through a theory of hegemony that encompasses and is broader than ideology). But to rely on ideology as the singular and primary explanation for an analysis of neo-liberal projects would be to invite ideologism, that is, ideological reductionism. Thus in this thesis, "new ideas are a 'necessary' condition for launching policy innovation [such as neo-liberalism] but they are not 'sufficient' in consolidating change" (Bradford, 1999:18). 
Augelli and Murphy (1988:13) contend that ideology plays a central role in Gramsci's work, as his primary focus was on reassessing superstructure in response to Marx's economism. Gramsci rejects the 'negative' view of ideology in Marx's earlier work, asserting that ideology is not an illusion or error, but has material force with both significance and real consequence. Augelli and Murphy show that Gramsci develops two adjunct (and interrelated) concepts of ideology, as worldview (idealist) and as political force (material). As a worldview, ideology appears as common sense, "fragmentary, incoherent and inconsequential" (Gramsci, 1971:419), an uncritical view of the world that must be judged within social and political contexts.

As a political force, ideology is both an instrument of liberation and domination. The philosophy of the dominant class isn't transferred into common sense wholly or directly, but instead leaves behind "stratified deposits" (Gramsci, 1971:324), thus creating a contradictory consciousness between the lived common sense of the subordinate classes and these ideological leavings. The liberating force of this worldview involves "freeing common sense from contradictory consciousness and developing and extending its sound core of 'good sense"” (Augelli \& Murphy, 1988:21), as opposed to common sense. As a dominating political force, the dominant class thwarts the development of common sense into good sense by trying to prevent the development of critical reason in the subordinate classes. This can be overcome by "the catalytic role of intellectuals" who help the subordinate classes acquire consciousness and offer alternatives to their situation 
(23). Ideology's power lies in the way the dominant class uses the material structure of ideology - the institutions and organizations that support it (24).

\section{Research Methodology}

This thesis relies on both theoretical explanation and 'theory in practice' in the form of three case studies that examine the conditions under which the neo-liberal government in Ontario constructed a war of position (prior to the 1995 election) and a hegemony.

The theoretical literature as reviewed above provides substantial theoretical material on which to base the analysis herein. This is the advantage of a thesis subject that seeks to add to a body of knowledge already in progress. The Thatcher hegemonic project in Great Britain has run its course in terms of analysis, with only the post mortems and long-term impacts remaining to be analyzed and put . into historical perspective. The British literature provides special assistance in the areas that drove analysis - the validity, character and success of a hegemonic project, class analysis and a focus on the international economy (i.e. Great Britain's place in the diplomatic sphere). New Zealand as well has sufficient distance from the actual restructuring process to be able to begin to assess future directions (as in Kelsey's more recent analysis). The New Zealand theoretical literature provides insights into the abuse of democratic process, elite dominance and debt discourse. To the extent that it is possible to draw conclusions about the character of an ongoing project, for which analysis is sometimes still in the raw form of "dispatches from the front" (Walsh, 1993:189) the focus of research and analysis in Ontario 
tends to be sectorally based. Although therefore piecemeal in nature, some work has been done that is useful here.

The three case studies rely on both primary and secondary research. The primary research involves both quantitative and qualitative research. The quantitative research is in the form of media analysis. The media analysis addresses Bruck's (1992) criticism that "[m]ost critical media theories are... inadequate in their treatment of empirical developments, namely, by failing to account for the often contradictory operation of the news media" (139). The empirical analysis in chapter 4 identifies such contradictions by examining how and suggesting why media coverage varied from or coincided with expectations based on other media analysis of the government communications campaign and citizen contestation found in Deacon and Golding (1994), media response to government legislation in Knight (1998) and oppositional resistance in Hansen and Murdock (1985). The media analysis assesses primary definition and accredited access (Hall et al, 1978). Hall et el suggest that some powerful and credible actors have "structured preference" to media because of their powerful or privileged institutional positions in society. Their systematic over-access to the media allows them to offer their opinions about controversial subjects and to have them accepted, that is, they provide the primary definition of an issue. Journalists circulate these definitions or preferred interpretations in their news accounts, thus internalizing the dominant power structure and reproducing symbolically its values for the public. While oppositional viewpoints appear in the media, they are represented in relation to primary definers and primary definition. Because of their structured relationship to 
power, the media as secondary definers are conduits of power or carriers of dominant ideology. In this way, the media "construct a particular image of society which represents particular class interests as the interests of all members of society" (59). Thus the focus of the media analysis is to provide more nuance to ideological closure, accepting that ideological closure is an expectation or a given within a dominant meaning system, but going beyond it to construct the conditions under which such closure takes place (Bruck, 1992:140).

The tables accompanying the analysis note each instance when social actors gain access to media accounts, which gives an idea of their proportional presence in a story. Messages are categorized by theme and by category of social actor (government/dominant, alternative or oppositional). The analysis also tests inclusion/exclusion in media accounts during different phases in the policy process (Deacon \& Golding, 1994) and in the bureaucratic and normative phases of media accounts (Fishman, 1980:ch.3). This is referenced against news releases from key government/dominant, alternative and oppositional social actors to attempt to verify the level of access accorded these actors (Deacon, 1996). In other words, the analysis examines "points where... movements and means intersected" (Raboy, 1984:16) or absences where a presence might have been expected. There are limitations to this method. Non-governmental actors, especially under-resourced groups, are often not able to supply complete sets of news releases or other documentation or to keep records of their group's media contacts. The analysis has been designed to provide information and insights into agenda-setting and framing, two main analytical tools of media analysis. 
The media analysis is supplemented by interviews with key actors from activist groups. This does not wholly solve the problem of incomplete records, nor is it intended to. The interviews were intended to probe communications strategies, level and adequacy of resources, proximity to government, opportunities for inclusion (media and non-media), and aims and main focus of the group (Deacon, 1996:185). Other interviews outside the circle of actors who might appear in media accounts were sought, notably with the vice-president of the main public opinion firm used by the government. This part of the project was indeed qualitative, as there was insufficient material to provide any more than a characterization or an insight into a particular event, but which in itself was useful.

In addition to the primary research through media analysis and interviews, government documentation was accessed and analyzed, including: requests under Ontario's Freedom of Information and Protection of Privacy Act for government communications strategies, issue sheets, messages and public opinion research; research and analysis of all Standing Committee hearings conducted by the Legislature of Ontario with the public; and analysis of forms of legislation in historical perspective with the record of previous governments. Research was limited by the lack of electronic holdings of the legislature, which meant that research had to be conducted from the original documents, and the lack of analysis conducted by the legislature itself — for instance, the numbers and dates of omnibus bills (a contentious form of legislation) had never been recorded separately.

The research was supplemented by the compilation of figures and tables of information from information found in the theoretical accounts (see list of tables). 
This information includes: electoral results by date, party and popular vote over the time period in question; economic and social indicators over the same time period, and selected public opinion research accounts showing public attitudes towards the government and specific government initiatives. Chronologies of relevant events, mainly from 1995 to 1997 , appear with each case study. Other research included accessing publicly available government documents from the government archives and the Ontario Legislative Library in order to have access to public opinion research records. In the case of the latter, considerable attention is paid to public opinion research in this thesis, despite its limitations as indicated in chapter 3. When conducting research and analysis of past events, however, public opinion research is one of the few tools available that can be used to recreate or reassemble public views.

\section{Chapter Summary}

Throughout this chapter, there have been indications of which areas of the thesis are to be found in which chapter. Here is a short overview:

The next chapter defines neo-liberalism and explains how it evolved. This is followed by a political, economic and social history of the construction of the post-war Keynesian compromise, the economic crises of the 1980s and the emergence of neo-liberal state projects in Great Britain, New Zealand and Canada. A brief look at the United States demonstrates the ideological and economic influence that country has on the others. The history of neo-liberalism in the federal Canadian context is followed by its specific application in Alberta and Ontario. The 
history demonstrates the specific conditions under which each manifestation of neoliberalism emerged, in keeping with Gramsci's theory of hegemony.

Chapter 3 addresses the strategic role of communication by examining the three spheres of political communication-government, media and public sphereand how their changing roles under neo-liberalism contribute to legitimation of the neo-liberal project in Ontario. The chapter examines Gramsci's duality of consent and coercion in the context of government restructuring, communication management and the political process; social citizenship and social movements and the tools of legitimation; and media systems, practice and commercialization. Emphasis in this chapter is on how the neo-liberal government constructs the conditions for its legitimation, both structurally and symbolically.

Three case studies are presented and analyzed in chapter 4 and the analysis continues in chapter 5 . These three cases were identified as occurring early in the mandate of the new government when the hegemony was in a transitional and vulnerable phase. Each case study demonstrates resistance to the government's restructuring, in different ways with varying success and in separate sectors. The case studies are also contextualized within broader resistance that, it is contended, held the potential of forming a Gramscian historic bloc in a war of position against the government. Chapter 5 also looks at instances in the Ontario neo-liberal project in which ideology 'failed.'

The final chapter focuses on the possibilities for Gramsci's counterhegemony in an examination of the impact of neo-liberalism on democracy, followed by an assessment of the strengths and weaknesses of the formal political 
process and social movements in achieving this task. Finally, the thesis suggests a role for communication, as communicative democracy, to contribute to a post-neoliberal polity. 


\section{CHAPTER 2: THE NEO-LIBERAL PROJECT: TRANSFORMATION OF THE POLITICAL ECONOMY}

This chapter will examine the philosophical antecedents of neo-liberalism. It will also give a history of the post World War II economic and political environment with respect to Western industrialized nations, the postwar Keynesian consensus, the growth of elite institutions and the transition to neo-liberalism. It will examine the historical and national specificity of the political, economic and ideological conditions constructed in Great Britain, New Zealand and Canada that led to neo-liberal projects, with reference to Alberta's experience and the influence of the United States. It will conclude with a discussion of the transformation of the political economy in Ontario. Throughout the chapter, the development and success of neo-liberalism will be linked to communication as persuasive hegemonic force and strategic political practice in legitimating neoliberalism. This persuasion is not without contestation and may not be successful or complete, as will be evident here.

\section{The New Right}

The terms 'neo-liberalism', 'neo-conservatism' and 'the New Right' are used often and interchangeably, but also inaccurately, to describe very different ideological positions that broadly reflect the revived and reorganized conservatism that has come to dominate Western industrialized nations (Jesson et al, 1988:6). ${ }^{1}$

\footnotetext{
'European nations favour "neo-liberalism", Great Britain and the United States "the New Right", and Canada uses both "neo-liberalism" and "neo-conservatism", although Quebec tends to use "neoconservatism."
} 
This renewed conservatism is both a reaction to the radicalism of the $60 \mathrm{~s}$ and 70s and a rejection of Keynesian economic and social reformism. Its economic credo is that the state has extended beyond its 'natural' limits into the sphere of the market, whose beneficial effects it has smothered; its social credo is that traditional moral virtues are declining and being replaced by the inevitable dependency and lack of selfreliance caused by the overextended and intrusive state.

It is simultaneously situated within a growing globalism that both weakens the state and plays off the weakened state. As an internationalized ideology, it supports "global capital accumulation along neo-liberal principles" economically and "challenges democratic assumptions about the sovereignty of states and national citizenry" socially (Parkland Institute, 2000:1). In its global forms, neo-liberal globalism is also called by a number of other names: Structural Adjustment Programs, the Washington consensus, ${ }^{2}$ the Wall Street-Treasury complex, Liberal Productivism and the New World Order (1).

It is not sufficient, however, merely to be aware of the different names by which the ideology of neo-liberalism is known. One of the points that will be emphasized in this thesis is the historic and national specificity of current manifestations of neoliberalism. This requires a more specific understanding of its philosophical beginnings. In addition, an understanding of the historical roots of neo-liberalism helps us not to overstate the influence of and support for neo-liberalism by revealing its contradictions. In turn, deconstructing its character can help in (re)constructing alternatives to it.

According to Jesson et al (1988), there are three main strands in the libertarian right: classic liberalism; new liberalism; and the Austrian economic school. In the

\footnotetext{
${ }^{2}$ John Williamson of the Institute for International Economics, who coined the term "Washington consensus", now prefers the less obvious term, "universal convergence" (Williamson, 1994:17).
} 
classic liberalism of the 19th century, the state was the main threat to the individual and the rights of the individual became the main focus and preoccupation of political life. The impact of individual rights on society was felt in social reform such as suffrage. Classic liberalism developed as a response to governing in the increasingly complex industrialized society of the 19th century (Isin, 1998:170). In new liberalism, the individual was still the subject, but the view of the state had changed. It was now needed to establish and ensure individual rights. The third strand, the Austrian school, had its beginnings in 1946 with the publication of Friedrich Hayek's The Road to Serfdom. Hayek's philosophy of individual and market freedom with an emphasis on the money supply and on inflation control gained prominence slowly while the post-war welfare state developed and then declined. ${ }^{3}$ Hayek's world-view emphasized "classical economic virtues of free markets, unhindered trade, fiscal prudence, price stability, low taxes, and a much reduced role for the state" (De Mont \& Lang, 1999:21).

As neo-liberalism, the economic-focused libertarian right is combined with an authoritarian right that focuses on social issues of morality and identity. It is this latter thread that has reacted to the changes in public morality and the social movements of the 1960 s and 70 s. For some, particularly in the United States, there is a religious motivation that emanates from the strong evangelical movement in that country. Overall, to the authoritarian right, re-establishing discipline and moral order in public life is paramount and the role of the state is to provide it.

${ }^{3}$ Hayek and fellow free marketer Milton Friedman won Nobel Prizes for economics in 1974 and 1976 respectively, after the cracks in Keynesianism began to manifest themselves. The Parkland Institute notes that recent Nobel Prizes in economics may be an early sign of a paradigm shift once again-1996 and 1998 prizes show "a return to the economics of fairness and ethics" (Parkland, 2000:4). 
Belsey (1986:173) illustrates the contradictions between the libertarian right (neo-liberalism) and the authoritative right (neo-conservatism) by signifying each with five major characteristics:

Neo-liberalism
the individual
freedom of choice
market society
laissez-faire
minimal government
Neo-conservatism strong government social authoritarianism disciplined society hierarchy and subordination the nation

While these pairs of characteristics seem to be opposites, when a characteristic from one list is matched with a characteristic from the other list, in New Right political practice, "there is much cross-over and no clear separation can be made. It is a mistake to ignore either side and their intermingling in practice" (Belsey, 1986:173). Ontario's economic policy is neo-liberal in nature, while its social policy derives from neo-conservatism.

On the one hand, this tells us that there are indeed obvious and seemingly irreconcilable contradictions between the two ideologies. To De Mont and Lang (1999), the New Right wants it both ways: "the evisceration of the welfare state and a sharply reduced role for government in the economy at the same time as expanded public dabbling through toughness on crime, restrictions or outright prohibitions on abortion, tight immigration policies, and some religious-based laws, particularly in the area of sexual orientation" (20). As Gamble (1993) points out, it is a contradiction that pits the traditional liberal free economy against the traditional conservative strong state:

The state is to be simultaneously rolled back and rolled forward. Noninterventionist and decentralized in some areas the state is to be highly interventionist and centralized in others. The New Right can appear by turns libertarian and authoritarian, popular and elitist (36). 
Belsey's analysis also implies that there is more than one right-wing ideology at play and thus contestation among them for pre-eminence. This is both a positive and negative force for the New Right. The many ideological and social formations made possible by regrouping competing ideologies and the groups that represent them can also mean that consensus among them for policy development may be difficult to achieve — or they could "enable the New Right to switch the grounds of its legitimation at will" (Levitas, 1986:11).

Yet, on the other hand, as Levitas (1986) also points out, there is often no policy difference in their application as the reconstructed ideology of the New Right. In addition, neo-liberalism and neo-conservatism as applied throughout the West have significant themes in common, such as nationalism, anti-feminism, surveillance and suppression of dissent, which can give the Right both more ideological and more economic explanatory power $(6,21)$.

The contradictions in the New Right ideologies should lead to caution in overstating the support for them as they have emerged in different states and jurisdictions over the past 20 or 25 years. There is related discussion surrounding their 'newness', in attempts to understand how the New Right seemed to replace the post-war consensus so quickly and, it seems, decisively. The conclusion reached by most ${ }^{4}$ is that the New Right ideologies represent a dormant or incipient liberalism that is situated within conditions that once again, after a long gap in time, are sufficiently supportive

\footnotetext{
4 Much of this discussion was stimulated by the work of Stuart Hall on Thatcherism, particularly the concept of "authoritarian populism" which was examined in Chapter 1. Note that The Ideology of the New Right (Levitas, ed.) was published in 1986, when the phenomenon that was Thatcherism was sparking considerable initial analysis by the left in Britain. Some of those who entered the discussion at various times were: Gamble, 1983; Hall \& Jacques, 1983; Williams, 1983; King, 1987; Jesson et al 1988; Jessop et al 1988; and Kavanagh, 1989.
} 
for it to become an electoral, and possibly hegemonic, force. These conducive conditions for success are joined not by new ideas, but by old ideas that have been "welded together into a new ideological synthesis" (5). But there is still reservation about the depth of support for the ideology and the politics behind the electoral successes. This will be discussed later in this thesis.

As a social force, the New Right is more influential in the United States than elsewhere due to the strong influence of the religious right. As an economic force, the New Right has enjoyed success in Great Britain, New Zealand and Canada. Due to its economic influence in Canada and the focus of this thesis on Ontario, the term "neoliberalism" will be employed in this thesis, although it will be understood to be an amalgam of the authoritarian right and the libertarian left, as delineated here.

\section{The Post-WWII Political and Economic Environment}

Before there was neo-liberalism, there was Keynesianism. Keynes's The General Theory of Employment was published in 1936 and quickly became the dominant economic position of the Western industrial nations. The key to the success of Keynes lies both in "identifying areas of market failure in capitalist monetary economies, and in prescribing policies that could remedy these failures without overturning the market system itself" (Roper \& Judd, 1993:28).

The test of economic theory, Bertram (1993) suggests, lies less in scientific discovery than in its success or failure as an economic policy experiment conducted by governments: "Macroeconomic models stand or fall, in the public domain, on the robustness of government failures based on them" (30). By this political and 
ideological yardstick, Keynesianism achieved sufficient intellectual ascendancy to construct the post-World War II world order. Keynesianism interventionist strategy 'dampened' if not controlled the economic cycles of the accumulation strategy known as Fordism, "the scientific management of work in large factories" (Warnock, 1988:29).

The actual strength of the post-war consensus attributed to Keynesianism has been questioned. Some have argued that there wasn't a consensus-and certainly not a socialist one-in response to neo-liberal claims of the death of socialism (Tiranti in Levitas, 1986:13-14). ${ }^{5}$ More clearly, the argument is that there was not a break between the pre-war consensus and the post-war consensus because an alternative system to capitalist accumulation was not put forward. But whatever the considerable inadequacies of the post-war period, this cannot be equated to a lack of consensus, which does not require "that all of the people are convinced all of the time, only enough of the people enough of the time" (17). The break with neo-classical liberalism may not have been as complete as many would have wished, but there were significant differences between it and Keynesianism in critical economic areas, such as inflation control, employment levels and exchange rates.

The Keynesian post-war consensus had an impact on social as well as economic relations. Changing social relations were characterized by a broadening of the conception of citizenship. The new social citizenship was an incomplete project of inclusion, which, despite its inadequacies, has been called "one of the defining features of the welfare state" (Sears, 1999:93). In different forms across Western industrialized nations, state policies standardized the population by establishing programs and benefits

\footnotetext{
5 Also, Panitch and Miliband (1992:3) write that "the implication of a new post-Keynesian world order implies that the old world order had been achieved."
} 
with minimum levels for social benefits such as income, housing, health and education. These minimum standards were enforced, so that at least partially, social reproduction was in effect "maintained and replenished" by the state (92).

The post-war consensus itself, often referred to as the 'compromise' (which was negotiated between economic and social interests in a social contract), was secured as a means for nations to secure their legitimacy after the turmoil of World War II:

"Capitalism required an environment conducive to profitability, while people demanded policies of redistribution and welfare to mitigate the harshest effects of capitalism, and democratic participation in determining those policies" (Kelsey, 1999:5). To some, the compromise was also compromising, in that it allowed an international reserve and a strong military and defence to co-exist with the commitment to full employment and other welfare state development, thus revealing "the hybrid and contradictory character of the post-war settlement and the limits of social democratic hegemony therein" (Jessop et al,1984:39).

An important reason for the immediate post-war economic strength and general societal stability is attributed by Warnock (1988:29) to the dominant and unchallenged position of the United States as the economic leader of the West. This dominance was exercised politically through military alliances, primarily to contain socialism and communism. It was exercised economically through the Bretton Woods agreements of 1944, which created the International Bank for Reconstruction and Development (World Bank) and the International Monetary Fund. The group of five agencies known 
collectively as the World Bank ${ }^{6}$ is "the world's leading development agency" and the largest multi-national agency for lending and development in the majority world (usually known as the Third World) (Halifax Initiative, n.d.:1) and the IMF, which oversees the international monetary system, monitors the economic policies of the member countries, maintains short-term currency stability and provides policy advice, together are owned by governments in the West and in the majority world and are run by a board of governors comprising each member country's Minister of Finance or the governor of its national bank. The top five contributing countries ${ }^{7}$ each have an individual executive director and vote. Other countries share their vote.

Although the Bretton Woods institutions were a stabilizing force for Western member nations, they also created "tension between [their] sovereign authority to set... national priorities and the requirements of international capital" (Kelsey, 1999:6). In addition, these institutions were structured to have substantial influence on the international economic environment, with the top contributors, including the United States, had the most influence. Thus the price of stability included allowing the United States to emerge as a dominant world power.

Thus the Western world entered the "golden age of Western capitalism" of the 1950s and 60s under conditions of stability and economic growth that seemed to "made plausible the claim and belief that capitalism had finally overcome its crisis-ridden nature" (Panitch \& Miliband, 1992:10). This encouraged the impression that growth would continue endlessly through the stages of capitalism and "shifted the ideological

\footnotetext{
6 The five institutions are: the International Bank for Reconstruction and Development, the International Development Association, the International Finance Corporation, the Multilateral Investment Guarantee Agency and the International Centre for Settlement of Investment Disputes (Kelsey, 1999:92).

7 In 1997, the five countries were: Britain, France, Germany, Japan and the US (The Halifax Initiative, 1997:1).
} 
rationale for... reformism towards a humane management of capitalism", (10) but the special conditions changed and the contradictions in the post-war compromise started to become problematic.

\section{Cracks in the Politics of Equilibrium}

The beginning of the 1960s was characterized by the "politics of equilibrium" (Girvan, 1994:190), that is, a state of balance that leaned toward stability and with no overt threat to the political or economic system on the horizon.

Against a backdrop of continuing increases in social welfare benefits and increased government taxation, there was sustained growth in the economy and a gradual rise in the standard of living (Warnock, 1988; Panitch \& Miliband, 1992; Girvan, 1994). The 1960s were also marked by the rise of Europe and Japan in economic importance and in increased competition to US business interests abroad. At the same time, and into the 1970 s, productivity declined, commodity prices rose, profit and investment rates declined (Warnock, 1988:32).

An unexpected challenge to the politics of equilibrium was on the social front in the form of the rise of new social movements. The challenge had both positive and negative aspects. New social movements, notable for their specialized "themes", 8 spoke to the strength of participatory democracy and the politics of inclusion practised in social democratic countries, and particularly in Canada (Dobbin, 1998:38). As Kelsey (1999:6) says, "[f]or most Western industrialized countries, the Keynesian era... fostered a deep integration of economic, social and political life." But their campaigns

8 "Theme" movements included: women, minorities, ecology, anti-war/disarmament, gay and lesbian, disabled and seniors (Wallerstein, 1990:41). 
to extend the state and be included in the consensus also constituted an organic crisis by fostering "New Right-wing responses (of both the libertarian and authoritarian kind)" (Spoonley, Jesson \& Ryan, 1988:26).

Although there were several declines in the economic cycle in the post-war years, the first major post-war recession took place in 1974-75. By this time, most countries were experiencing the effects of what was later understood to be a major crisis, but which at the time was hidden by preoccupation with inflation as the most serious problem facing capitalism (Warnock, 1988:33). "Debt" and "deficit" entered the public discourse as public and private debt increased, debt payments rose and economic growth declined. As a result of high inflation, most Western nations raised interest rates substantially and began to cut back on government spending.

In the 1930s the insurmountable economic problem was unemployment. In the 1970s, it was now inflation, but this time, against Keynesian economic orthodoxy, unemployment was rising along with it. This unprecedented "stagflation", for which Keynesianism did not have an answer, provided space for market economist Milton Friedman ${ }^{9}$ and his monetarist solution: restrict the growth of the money supply and remove governments from intervening in fiscal and monetary policy. The 1980s began with a second, deeper world recession. In effect, "the accord between labour and capital had collapsed" (Warnock, 1988:34); while capital was experiencing declining profits and looking to slash costs, labour wanted wage settlements that matched the high inflation rate.

9 Friedman and other monetarist economists at the University of Chicago rose to prominence as advisors to the Pinochet government in Chile in 1973. On their advice, Chile's inflation came under control, but unemployment rose from $7 \%$ to $30 \%$ (Warnock, 1988:34). 
Canada's response to the crisis was not unlike that of other countries, such as Great Britain, Germany and France. Wage and price controls (or income policies) were imposed (Bradford, 1999:34) and, by 1975, the governor of the Bank of Canada had begun to gradually introduce a policy of monetarism, to control inflation through increases in the prime interest rate. This "interlude between governing paradigms" (Bradford, 1999:37) also saw budgetary deficits became cumulative and interest began to absorb budgets and threaten social programs (Albo, 1995). Canada was not alone in its largely unsuccessful attempts to mitigate the growing crisis: then, and later "through the course of the 1980s[,] not a single welfare state remained immune from severe measures of fiscal austerity and regressive changes in taxation" (Panitch \& Miliband, 1992:12).

During this time of the gradual shift away from welfare state fiscal policy, labour-government relations in Canada began to deteriorate (Panitch \& Swartz, 1988). The wage and price controls of 1975 , widely accepted to have controlled workers' wages but not consumer prices, coincided with the Bank of Canada's turn to a monetarist interest rate policy.

A further stress on the Canadian economy was the internationalization of production, which freed up multinational corporations to move production out of Canada in search of cheap labour, deindustrializing Ontario in particular with major job losses and developing "capital's institutional capacity to operate on a world scale" (Leys, 1992:26).

Girvan (1994:207) asserts that the recession provided a trigger for the political, economic and ideological shift that followed, as the "growing confrontation between 
left and right... was increasingly defined in terms of ideological polarization." Responses to the recession reasserted a classic policy cleavage, with conservatives looking for solutions in anti-inflationary strategies and the Left defending full employment policies; the state's decisive response with anti-inflationary measures gave conservatives an initial political and ideological success (207).

\section{The Growth and Influence of Elite Corporate Institutions}

The questioning of the welfare state was fanned by elite institutions, both national and international, and elite forums that either already existed or were formulated or grew to prominence in the space between the breaking down of Keynesianism and the shift to neo-liberalism. These elite institutions are part of "intellectual-material networks" (Gill, 1988:231) that have occupied many overlapping spheres of influence over the halfcentury since World War II and have taken many forms:

The then-named ${ }^{10} G 7$ summit of Western industrialized countries was organized in 1975 to promote the economic interests of those countries. Panitch and Miliband (1992:12) say summits, which started informally and have now been regularized annually, represent the internationalization of the state that (mostly) took place after the 1992 recession. Such meetings lend legitimacy to institutions like the International Monetary Fund (IMF) and the General Agreement on Tariffs and Trade (GATT) ${ }^{11}$-the latter now superceded by the World Trade Organization—and the economic agendas of

\footnotetext{
10 Russia has entered the G7, which is now called the G8. There are other such international forums for heads of state and their lead economic ministers, such as the G23 of Western finance ministers (which met in Ottawa in November 2001).

11 In 1947, Canada and 23 other countries signed the General Agreement on Tariffs and Trade. Member countries had the status of "most favoured nation", which meant if a member country reduced tariffs on commodities for one other member country, it would automatically extend to the others. Membership gradually increased to 120 signatories (Dobbin, 1988:91).
} 
the G7 have become increasingly integrated with the IMF and GATT/WTO. The summit plays two roles. It creates a consensual discourse (so that all speak the same language) and capitalist solidarity (so that they mutually reinforce each other) (Panitch \& Miliband, 1992:12-13).

The Bretton Woods institutions-the World Bank and its component institutions, along with the International Monetary Fund-have played increasingly important roles in the development of both industrialized and majority world countries. As Ellwood (2001) says, the purpose of the Bretton Woods institutions "was not to bury capitalism but to save it" (27). Their work benefited the economies and stability of its capitalist member nations. In return for the loans to majority world countries at low interest rates, ${ }^{12}$ the WB and IMF imposed conditions, known as structural adjustment policies, that dictate market-oriented economic and social policies within the debtor countries (Dobbin, 1998:91). As of the late 1990s, the WB sees the need for a restricted state that complements and serves a competitive market economy — but its approved strategies are still consistent with structural adjustment policies (Kelsey, 1999:97-99). Williamson (1995:3) says that the "authoritative summary of the market-friendly view" can be found in the WB's report, World Development Report 1991: The Challenge of Development. $^{13}$

Created in 1995, the World Trade Organization has "profound implications for national sovereignty" (Dobbin, 1998:99). The WTO now extends to trade in services, which has the potential to globalize and harmonize national policies in an estimated 160

\footnotetext{
12 The low rates were intended to and succeeded at discouraging the majority world countries from forming their own self-owned and led international institutions (Ellwood, 2001:31).

${ }_{13}$ Chapter 7 of Williamson (1994), "Rethinking the State", provides details on how to reform the public sector as well as a staged planning matrix on moving to a market economy.
} 
areas, including telecommunications, health and education, banking and the environment, especially through its dispute settlement body, which has legal authority to approve trade sanctions for breaking WTO rules (Kelsey, 1999:246; Ellwood, 2001:32, 34). Dobbin (1998) explains that "the IMF and the WB policies established corporate rights throughout the less developed countries of the world. With the WTO, it [wa]s now the turn of the industrialized countries to turn over their decision-making authority to global corporations" (100).

The Trilateral Commission (TC) is another elite organization that has influenced the international and national policy environment. Funded initially by US corporations, ${ }^{14}$ the TC was created in 1973 to build consensus in the three world regions that it represents: North America, Europe and Japan. ${ }^{15}$ It commissioned a report, published as The Crisis of Democracy, which said industrialized nations were experiencing a breakdown of democracy from within caused by uncontrolled demands from the popular sector that needed to be limited by reconstituting democracy to prevent instability (Crozier, Huntingdon \& Watanuki, 1975). The recommended action for governments was, in effect, less democracy and more "deception" (93) and "coercion" (113) of the public, both at home and abroad.

The 'free' trade agreements Canada-US Free Trade Agreement (1989), North American Free Trade Agreement (1994) and Free Trade Agreement of the Americas

14 These included General Motors, Exxon, Coke, Time and CBS. Dobbin, pp. 159-160; The TC's first director was Zbiegniew Brzezinski, later national security advisor to Jimmy Carter (Crozier, Huntington \& Watanuki, 1975).

15 Membership numbers have varied over the years, but cumulatively from 1973 to 1985 they divided as follows: North America - $34 \%$, Europe - $41 \%$ and Japan - $25 \%$ of members. Canada held $6 \%$ of members in that time period compared to the US's $29 \%$. By occupation, members represent: business $28.6 \%$, politics $-24 \%$, banking $-7.6 \%$ and academia $-5.6 \%$ of members. (Calculations made from information in Gill, 1988:232.) 
(target date: 2004) have also extended economic integration or, less euphemistically, market liberalization. The agreements restrict governments from interfering in market freedom that transcends borders. Critics of these agreements believe they have boosted the power of corporations to the point that they have been called "a charter of rights for transnational corporations" (Dobbin, 1998:xx) and "an external... constitution for Canada" (Clarkson, 2003:7).

These elite institutions are linked by their interests of monopoly capital to enhance and legitimate the emerging neo-liberal hegemony. ${ }^{16}$ In Gramscian terms, acting as intellectuals and organizers of hegemony, they developed their consciousness and solidarity in these international organizations and forums and formed coalitions based on shared interests on how the world should be run (Gill, 1988:50). These institutions and their members had sufficient authority and influence to form a fluid transnational historic bloc to anticipate and respond to the economic challenges of stagnation, recession and currency crisis. As The Crisis in Democracy demonstrated, there was also a perceived need to manage the challenges posed by participatory democratic movements.

In Canada, the proliferation of elite organizations also took different forms, such as taxpayers' coalitions, research institutes ('think tanks') and business lobbies, but as an emerging "hegemonic fraction" (Langille, 1987:46), their common purpose was clear: The corporate interests they represented

\footnotetext{
16 There are, of course, other international institutions, as well as national forums, with the same aim of consensus building for the promotion of market liberalization and other interests of capital, but the organizations mentioned here are representative. These other organizations include: the Bilderburg forum, the Organization for Economic Development and Cooperation (OECD) and the World Economic Forum (Dobbin, 1998: ch. 5).
} 
could no longer afford to make the concessions or compromises entailed in a democratic, pluralist system... [N]either the state executive nor the bureaucratic apparatus appeared capable of adequately representing the interest of monopoly capital, or of organizing the compromises that would maintain the latter's hegemony. Therefore the hegemonic fraction itself had to step in and perform this role. Faced with an economic crisis which the state had contributed to but so far had failed to resolve, the hegemonic fraction organized the power bloc so as to exert a direct influence over the state (46-47).

Ernst (1992:110) says changes in state policies can be monitored through the history and policy discourse of policy and research institutes, which, as leading fractions of capital, have been important in providing the ideological framework for the restructuring of the global economy. This, he says, is clearly seen in the shift in the policy discourse of the C.D. Howe Institute, which moved away from a politically Liberal orientation to neo-liberalism in the early 1980s (Klein, 1996:55).

Think tanks define problems, shape public opinion and help set the policy agenda (Pershek in Ernst, 1986:112). They have varying priorities (usually either policy research or political advocacy) which determine where they enter into the policy cycle (at the issue articulation, policy formulation or policy implementation stage) (Abelson, 2002:57, 167). They are "active agents linked to power blocs and policy currents, reflecting and, in turn, shaping ideological shifts and political regroupings in a time of momentous economic transformation" (Pershek in Ernst, 1986:112). This is reflected in the proliferation of neo-liberal-focused research institutes in the US in the early 1970 s during that country's economic crisis. ${ }^{17}$ It also coincides with the same period of growth of think tanks in Canada to more than 100 today (Abelson, 1999:94;

\footnotetext{
17 The prominent right-wing US think tanks, the American Heritage Enterprise and the Heritage Foundation, both emerged at that time (Emst, 1992:112).
} 
2002:17), many of them linked ideologically and economically to powerful structures, such as large corporations (Ernst, 1992:114).

The Fraser Institute (FI) was founded in 1974 by the chair of Noranda Corporation and "other key executives of transnational corporations" (Dobbin, 1998:183) as the business response to perceived failures in the welfare state and its ability to handle the economy. Its creation was also a response to welfare state successes and the "heyday of economic nationalism and social democratic thought" (Ernst, 1992:121-122). As Canada's largest, privately funded research institute, its budget is upwards to $\$ 3$ million, all from its 2,500 individual and corporate members (Abelson, 2002:30; T. Clarke, 1997:251). The FI has worked to counter the ideas of the Left and bring the neo-liberal perspective into Canadian policy making in a manner that has been described as "openly ideological" (Klein, 1996:55; Dobbin, 1998:185). It concentrates much of its activity on education and communication to promote its message of the new business agenda of tax freedom and debt reduction.

The C.D. Howe Institute (formed in 1958, but reconstituted in 1973) is a research-oriented institute. Member corporations and individuals provide its estimated $\$ 3$ million budget (Abelson, 2002:30). Its justification for its shift throughout the 1980s from Keynesianism to neo-liberalism was a "there is no alternative" rationale of the perceived need for adjustment and flexibility, given the move to freer markets internationally (127-128).

Established in 1976 by the chairs of Imperial Oil and Noranda Corporation (Dobbin, 1998:166), the Business Council on National Issues (BCNI) represents more than 150 chief executive officers representing the largest Canadian industries with 
combined assets of $\$ 1.5$ trillion (T. Clarke, 1998:249). The aim of the BCNI, as stated by its then-president, Thomas D'Aquino, is "to be the most influential voice of business in the national public policy arena, to try to change some of their values as well as the policies, of our society while respecting the fundamental aspects of the market economy" (Langille, 1987:84). With many of its member companies foreign-owned (Bradford, 1999:37), BCNI "organized the power bloc" to influence federal free trade policy, wrote the government's competition legislation, was involved in a new energy accord that saw more profits going to oil companies and campaigned against a proposed interventionist industrial strategy (Langille, 1987:47, 52; Workman, 1999:63). ${ }^{18}$

Other elite institutions ${ }^{19}$ that have influenced neo-liberal policy making in Canada through what Carroll and Coburn (2003:83) have called "business activism", include the National Citizen's Coalition, which was founded by a business person with connections to former Alberta premier Ernest Manning (Dobbin, 1998:183), and which has had success in ensuring freedom for third-party advertising in federal elections (NCC, 2002a) and has fought against labour rights (Clarke, 1997:252; Dobbin, 1998:197-198, 203, 205). NCC's former chief executive officer was Stephen Harper, now leader of the federal Canadian Alliance, formerly Reform, party.

This short history of the elite institutions that have influenced the shift from Keynesianism to neo-liberalism reinforces Ernst's hypothesis that these forums are stronger in regime shifts (1992:114). An important role that they may have played through their advocacy in the 1980s and early 90 s was in pre-conditioning policy

\footnotetext{
${ }^{18}$ Dobbin (1998:93) reports that 33 of BCNI's member corporation had a net loss of 188,000 jobs between 1988 and 1996, while their combined revenue increased by more than $\$ 40$ billion. 19 Some other such organizations include: the Canadian Taxpayers' Federation, the Economic Council of Canada (until 1992) and the Public Policy Forum (Abelson, 2002:193; Clarke, 1997:251-252).
} 
makers and the public for the ideological offensives that came later in Alberta (1992) and Ontario (1995) (Langille, 1987:75). ${ }^{20}$ The work of elite institutions has contributed to the construction of a public policy environment within which "policymakers are turning increasingly to think tanks to provide expertise and to stimulate informed debate on a range of issues" (Abelson 2002:165). An example of this (and how elite organizations can globalize their work) is in the new World Bank efforts to have think tanks "help build policy networks between researchers and policymakers both within and across countries" (168).

At the same time, one must be careful about overestimating their influence, which is difficult to pin down (169). To do so would be to imply that there are no conflicts or contestation within these institutions or that they stand alone as the factor that determines public policy, when in fact there are many open entry points into that process, including consultations and hearings (McCormick, 1989:9-10), and many elements in the process of embedding hegemony (Bradford, 1999:25). As Kelsey (1999) says, think tanks "cannot, by themselves, construct a new orthodoxy. Whether their ideas take root will depend on the extent to which they cross-fertilize with other intellectual, political, social and economic conditions" (67). Instead, these institutions work towards hegemony, understanding that their work takes place from a position of power and that it "is not simply something which happens... It is, in large part, the result of a permanent and persuasive effort, conducted through a multiplicity of

\footnotetext{
${ }^{20}$ Langille was writing in 1987 . His concern at that time was that even though the advocacy was for a neo-liberal policy environment (characterized by free market individualism), neo-conservatism (whose emphasis is on traditional values and social control) would arrive "through the back door" instead. He did not mention Alberta and Ontario specifically (44).
} 
'superstructural' agencies and instances" (Robinson, 1996a:24). That persuasive role of elite institutions will be discussed in chapter 3 .

\section{The Attack on Keynesianism and the Transition to Neo-Liberalism}

In times of uncertainty or crisis, conservatism represents order, normalcy and certainty, a return to key values, whereas the post-war consensus implied continuous change and improvement to a better quality of life (195). The post-war consensus was an uncomfortable fit for many conservatives, as its emphasis on welfare state provisions and social citizenship was defined more by the centre-left: "Neither convergence nor corporatism [Keynesianism] seemed to benefit conservatism in electoral terms, nor did it provide a means to regenerate the economy during the recession" (207).

Interest and support for monetarism had been growing in response to the stagflation crisis, especially to solutions proposed by Milton Friedman. In 1977, the OECD published a study that viewed monetarism positively and did much to give it respectability (Warnock, 1988:37). The study questioned post-war economic policies and promoted Friedman's monetarist strategy to "halt the inflationary spiral and restore profitability to the capitalist system" (37). Although the motivation for the change in economic direction was ostensibly to cure stagflation, declining profitability meant that new strategies of accumulation needed to be explored. Neo-liberal policy reforms such as a tight monetary policy, government restraint and social service cutbacks, and freedom from full employment policies held the promise of higher profits.

In 1980, the Liberals, who had ruled since the early 1960s but had lost power briefly in 1979, won the federal election in Canada. Although they did not ask the 
electorate for a mandate to implement an alternative to Keynesianism, they nevertheless appointed the Macdonald Commission to explore the future of the Canadian economy (Bradford, 1999:39). By the time the Macdonald Commission reported in 1984, after extensive hearings across the country, the Bank of Canada's monetary policy saw the prime interest rate rise to $17 \%$ (the commercial rate was $22 \%$ ), inflation declined to 5.8\% and unemployment peaked at 13.9 percent (Warnock, 1988).

Bradford (1999:48) has said that royal commissions are "decisive institutional areas where idea generators and social interests converge to redraw the road maps for the Canadian state and polity." In the case of the Macdonald Commission, however, there was no convergence; instead, the commission listened to conservative business and academics, who provided "an alternative model that directly addressed (economic) conditions and imperatives" (Klein, 1996:66), backed up by theory and extensive research. In contrast, popular sector groups addressing the commission hearings "dealt with issues of social justice, but not with those of economic growth and efficiency" (66). Ultimately, the Macdonald Commission report rejected forms of the welfare state in favour of monetarism and other market liberal policies, including liberalized trade (Warnock, 1988:48). In short, "the commissioners judged neo-liberalism superior in almost every way" (Bradford, 1999:40).

After the recession of 1982, a different Canada was beginning to emerge. The attack on labour widened into an encroachment on the universality of social benefits and other welfare state provisions. Unemployment remained high throughout the decade, while unemployment insurance benefits began a downward spiral of more and more limited benefits. At the same time, the 1980 s was a time of retrenchment for 
corporate interests as they sought to protect their interests and maintain prosperity (this was made easier by the containment of organized labour). It was the beginning of policy making that no longer benefited all members of Canadian society (Girvan, 1994:207).

Other international events were also influencing policy direction. The crash of the stock market in 1987 and the fall of the Soviet Union created an environment of uncertainty for both labour and capital. This was followed by another world economic crisis-the North American and European recession of 1993, heralded by a deeply troubled US economy, which was "even deeper and more stubborn" (Panitch \& Miliband, 1992:7) than the one in the early 1980s. The system of fixed foreign exchange rates collapsed, which was a breakdown in the Bretton Woods system, and by 1993, all currencies were floated on the international market. bringing with it the "fluctuations, greater instability and financial insecurity" of the free market (Girvan, 1994:216). The restoration of economic order, both at home and abroad, became an important factor in the renewed development of conservatism. That, and the long domestic and international economic crisis, turned business interests towards trade liberalization, beginning with the 1988 bilateral agreement with the US (Warnock, 1988:27).

Even if Keynesianism had not been fully realized and was therefore not able to reach its full potential, it had made a substantial impact on the role of the state in the post-WWII world order-a role that was now being questioned by both the Right and 
the Left (Held \& Keane in Levitas, 1986:12-13): ${ }^{21}$ "In questioning the role of the state, the New Right were tapping an important groundswell of feeling that the state was too large and cumbersome. Many people felt that the state has intruded upon the privacy of its citizens and that the power of the state ought to be curbed" (Jesson et al, 1988:14)

Robinson (1996a) believes that the time of transition from one epoch to another such as the one marking the transition from Keynesianism to neo-liberalism is "a great historic crossroad" and "a particularly strategic moment for humankind" (3). ${ }^{22}$ In this strategic moment of transition, "the profound changes underway, and the correlation of forces that emerges in this period, will determine the contours of the emergent twentyfirst century global society" (3), but its direction and outcome are still unknown.

The "correlation of forces" Robinson refers to is a historic bloc under construction within what Gill (1992) calls "patterned disorder: movement towards the attempt to consolidate a new form of hegemony within the core of the system (157)." Although the conditions that will determine contours of the new polity are not pre-set, neither do they develop on neutral ground. The delegitimation of Keynesianism already encompassed the failure to control inflation (blamed on loose monetary policy) and high unemployment (blamed on workers pricing themselves out of jobs); now it needed to restructure and 'roll back the state' by getting rid of the regulations and controls that prevented the market from stabilizing the economy.

21 Particularly in the pre-Thatcher days in Great Britain, the Labour Party and others expressed reservations about the weight of the welfare state. When in 1976 the Labour government accepted IMF conditions on a loan, one left analyst later wrote that Denis Healey "became Britain's first monetarist Chancellor, a step which... heralded the era of Thatcherism..." (Gill, 1992:160).

${ }^{22}$ Robinson says this is the beginning of the fourth epoch in the modern world, the other three being 1492 , "when the world system was born" (3), the 18th century bourgeois revolutions and the Soviet Revolution of 1917 with created a socialist-capitalist tension. 
Neo-liberalism, and the simplistic explanations it provided, was "a relief to politicians and other social actors who get to be part of the decision making process. The new classical [policy] package was simple, clearcut, and very attractive to beleaguered politicians... [It] gave politicians the chance to abdicate, with a clear conscience, many of the responsibilities which the State had assumed in the preceding decades" (Bertram, 1993:36). In addition, minimal responsibility for government other than for monetary policy and balancing budgets provided an "alibi" for politicians; they no longer needed to fulfill the expectations of the public, as that was up to the market (37). Although the new construction was a political and ideological choice, it was presented as 'natural' and, further, as if there was no possible alternative. ${ }^{23}$

\section{The Construction of Neo-Liberalism in Great Britain}

What has been universally called the "crisis of the British state" (Hall \& Jacques, 1988:123) and referred to by Gramscians as "the organic crisis" (Hall \& Jacques, 1984:42-43), is the conjuncture of specific historical, economic and political conditions in Britain which created space for a new polity to develop. Post-war industrialization had faltered (Jessop, 1989:269) and slow economic growth was a preoccupation of British governments that fostered the sense of a problem that needed to be fixed (Skidelsky, 1988:3-4). The 1970s was dominated by "crisis management and containment strategies dovetailed through an increasingly interventionist state" (Hall \& Jacques, 1988:43). Economic instability and decline led to a political crisis, what Jessop et al (1988:166-167) called "the dual crisis of the state" as Labour governments

\footnotetext{
${ }^{23}$ This would come to be the rallying cry of Thatcherism and has been derided by critics under the acronym "TINA" - there is no alternative (Kelsey, 1995 and others).
} 
failed and the Conservatives were intellectually in flux. For the latter political party, this provided the impetus for an emerging hegemonic bloc,

an alignment of rightwing forces around a political project to roll back the economic and social gains of the working class and to impose an austerity programme in which capital and state could regain the autonomies which they had enjoyed before the postwar settlement drew them into a series of compromises and alliances whose dynamic they could not control (166).

Other political factors of importance in the 1979 election that brought the Conservatives under Margaret Thatcher to power included the diffusion of politics across a third political party and the changing social base of support for the two main parties. ${ }^{24}$ Thus Thatcherism arose out of political struggle and economic crisis at home and abroad (particularly as a result of the fall in US economic domination), the political failures of previous British governments and changes in the social bases of party support (Gamble, 1993:15-16; Skidelsky, 1988:2).

The Conservative Party won the 1979 election, owing much to the simplified election platform "manifesto" (Stephenson, 1980:17; Riddell, 1983:138) that, like the campaign messages crafted for the campaign by one of the world's largest advertising firms, Saatchi \& Saatchi, resonated with voters. ${ }^{25}$ With that firm's expertise, the Conservatives had also conducted a pre-election campaign in 1978 under the slogan "Labour Isn't Working" (Thatcher, 1995:411). For the election, Thatcher positioned the Conservatives as the last chance to halt Britain's decline and emphasized that there was no other way and no other party to that was committed to this unpleasant job.

\footnotetext{
24 This was an ongoing process that saw moves in party allegiance by the new middle-class from Labour to Conservative and the skilled working class from Labour to third parties (Skidelsky, 1988:18; Leys, 1985:7).

25 The manifesto has been described as "long on general statements of principle... [and] unusually short on specific commitments" (Stephenson, 1980:17).
} 
Communication played an important role in the emergent hegemony in other ways, by helping the government both to win electorally and to maintain power. In gaining power, the British popular press endorsed Conservative positions on many issues and helped communicate Thatcherite policies to the public favourably (Jesson et al, 1988:55). The Conservative party also spent large sums of money on television advertising, public opinion research and professional consultants versed in new campaign technologies (Ginsberg, 1986:173). Once elected, the Prime Minister's Office introduced centralized control of government public relations and communications activities (Ingham, 1991), including media briefings and strategic "leaks" (Hetherington, 1989:294). Subsequently, the government built up its communicationsrelated activities on an "unprecedented" scale and with an emphasis on "public relations minders" (Golding, 1995:35-6). Between 1975 (the government came to power in 1979) and 1988, government communications budgets rose from 20 million pounds to 200 million (from $\$ 460$ million to $\$ 4.6$ billion Canadian), much of it on promoting privatization projects (Golding, 1991:507).

Media systems also underwent changes during the Thatcher governments that had an impact on the ability of the government to communicate its policies successfully. By $1991,88 \%$ of national newspaper circulation was controlled by three media chains, "each of them significant media corporations" (Deacon \& Golding, 1991:291). The rightward lean in the main national popular press was countered by a strong local and regional press, with 900 small newspapers across the United Kingdom, with "formidable power... for local agenda-setting" (this was a factor in the failure of the poll tax campaign) (Deacon \& Golding, 1991:292). Public broadcasting was slated for 
privatization during the Thatcher administration, but was prevented due to public protest (Bagdikian, 1997:250).

Thatcher's initial success owed much to her ability "to associate the worst aspects of the state with the Labour Party whereas she identified with 'the people' in opposition to the state" (Jesson et al, 1988:15). This she was able to do by couching her economic beliefs and policy prescriptions "in the language of common sense, moral imperatives and experience" (Hall, 1983:28). Underneath the populist discourse lay a neo-liberal (market-oriented) economic strategy, which promised greater economic freedom, but which was laced with a reactionary and authoritarian populism that promised an interventionist state role on social and moral issues (Levitas, 1986:2).

Although British voters gave the Conservatives an electoral majority, this was not so much a vote for the Thatcher platform as a vote against the failures of the previous government. ${ }^{26}$ There have been suggestions, notably by Hall $(1984,1988$, 1989), that the 1979 election represented a popular revolt, but the evidence points to a less sturdy endorsement than ideological acceptance of a new paradigm. But, driven by the highest unemployment in 40 years and huge price increases, aided by the changing social base of party support and the emergence of third political parties, and with a Conservative party not united internally, there were perhaps more pragmatic political and structural reasons for the victory than evidence of a fundamental ideological shift (Butler \& Kavanagh, 1980:344; Stephenson, 1980:27; Riddell, 1983:40; Edgell \& Duke, 1991:71). What the election revealed was the openness of the British electorate to populist proposals put forward by the Conservatives (Riddell, 1983:40) and their

26 Even with the majority, the Conservatives still received less of the popular vote than in most of the post-war elections except 1974 (Riddell, 1983:39). 
willingness to take an electoral chance despite their views (Butler $\&$ Kavanagh, 1980:340; Crewe, 1988). The importance of the first Thatcher victory in the context of the dual crisis of the state lay in the opportunity it gave the new prime minister "to consolidate her position despite initial unpopularity and resistance" (Jessop et al, 1988:166).

Nevertheless, like most political parties, the new government interpreted its electoral success as a mandate to carry out the policies of deficit and inflation control in its manifesto (Edgell \& Duke, 1991:70). Although its 1983 election manifesto hinted at "difficult choices ahead" (Riddell, 1983:240), the Conservatives were returned to office with an increased majority. Again, there were many reasons for this second victory, ${ }^{27}$ but one dominated: the 'Falkland factor.' Britain, with the support of the US, was victorious against Argentina in the short Falklands-Malvinas war of June 1982 which moved Thatcher's personal popularity from a low of $25 \%$ satisfaction in December 1991 to a high of $54 \%$ in the months after the war (MORI, 2002:16). These satisfaction ratings held for the next year until the general election. Gamble's (1982) analysis of the election results concludes that the Conservatives showed they could mobilize votes, implying an ability to forge the strategic alliances necessary to a consensus, but they had not yet shown that they could halt the economic decline (14).

The period after the second election continued the process of consolidation of the Thatcher project into a new consensus. The significance of the election result was not that the Thatcherite consensus had been achieved, but instead that "the New Right...

\footnotetext{
${ }^{27}$ Labour electoral support continued to erode, part of a long-term trend, and the split between factions on the Left continued (Gamble, 1982:8-9). Most remaining Labour votes were from traditional sectors of support, while the Conservatives captured support in sectors of society where there was growth (Massey, 1983:16-17).
} 
won the battle to shape the new consensus" $(8,13) .^{28}$ The shaping of the consensus was not a foregone conclusion, despite the two election victories. Public opinion research continued to show that, while they voted for the Conservatives, the British continued to reject one of the government's major policies, tax cuts, and showed even less support for the supposed inevitability ('there is no alternative') of such cuts (Edgell \& Duke, 1991:73-74). Research also showed that ordinary voters agreed with pro-market stances, but were not anti-state, seeming to find the two positions complementary, rather than in conflict (R. Rose, 1983:14).

By the time she was voted out of office by her party in 1990, Thatcher had incrementally and steadily undermined corporatism and replaced it with a strong and centralized minimalist state. Decisions were made in Cabinet and bypassed traditional "consociational consensus", especially labour and local government (Girvan, 1994:211). Thatcher's gradualist style, becoming more radical as time passed (Riddell, 1993:243), and her focus on the long-term slowly undermined the welfare state. ${ }^{29}$

Thatcher, along with her successor, John Major, under whom the Conservatives had a subsequent electoral majority, is widely considered to have successfully established a new consensus in Britain (Girvan, 1994:211) and, indeed, a new Conservative hegemony. But hegemony requires more than a coherent project. Gamble (1993:249) suggests that economic hegemony was within Thatcher's grasp in 1987, but that it evaporated with subsequent economic recessions. As Jessop (1988:180) agrees, the "economic nucleus of hegemony or the structural forces of power" must be

\footnotetext{
28 Italics added.

29 This ability to set sights on long-term objectives and not be deterred was remarked on by her press secretary (Ingham, 1991). Put differently, Thatcher was also widely said to have a vision, but no strategy for implementing it (Riddell, 1983:165).
} 
examined, as success or failure of a hegemonic project is "dependent on the capacity of the accumulation strategy to continue to provide economic growth" or the long-term transformation of the state. The ideological dimension of Thatcherism deserves more scrutiny. As important as the economic aspects of hegemony are, for they must provide the necessary structural supports, Gramsci emphasizes the permeation of ideology through civil society. Thatcher's ideological success owes much to her ability to reconcile the different strands and concerns of the new Right into an amalgam of organic Toryism and revived neo-liberalism (Hall, 1983:29), and translating that populist and theoretical mix into popular idiom (Spoonley, Jesson \& Ryan, 1988:23). Thatcherite populism contained organic elements that had already been secured in earlier times and through lived experience (Hall, 1988:48). The promulgation of the ideology took place at the intellectual level and then found resonance at the political and civil levels.

Two influential Conservative think tanks that led the changes in the intellectual climate are the Centre for Policy Studies (CPS), which Thatcher co-founded, and the Institute of Economic Affairs (IEA). According to Thatcher (1995:253), the CPS developed "the drive to expose the follies and self-defeating consequences of government intervention. It continued to engage the political argument in open debate at the highest intellectual level." On its part, since 1957 the IEA had been promoting New Right arguments against the social democratic orthodoxy (King, 1987:68; Thatcher, 1995:254) and was credited by Thatcher for providing "inspiration for many of the policies which our Conservative government has put into practice" (254). A further New Right think tank, the Adam Smith Institute, joined the others in promoting 
and disseminating the political and economic ideas of free marketism to politicians and bureaucrats (King, 1987:68).

One of the contradictions in Thatcherism was the strong ideological force of its beliefs that nevertheless often dissolved into political pragmatism. Thatcher herself insisted that she always chose "the economic", as she put it, over the political and would not backtrack, but this was only true when she could achieve both ends. ${ }^{30}$ The evidence suggests that despite the rhetoric, Thatcher often was inconsistent, "zigzag[ging] towards her goals" (Skidelsky, 1988:1) pragmatic in her means of achieving them (King, 1987:113-116) and changing her short-term strategic vision (Jessop, 1988:811; Stephenson, 1980:112-113). The mixed conservative-libertarian antecedents of her ideology might also have played a role in undermining the cohesiveness of her political practice; three of the five main proposals in the party election manifesto of 1979 were libertarian in nature, while the other two were conservative. $^{31}$

Thus questions remain about the substance and durability of the ideological dimension of Thatcher's hegemonic project:

The establishment of a durable hegemony requires the emergence of a consensus both on the desirable shape of society and on the policy priorities of government. True hegemony comes about when there is no longer serious conflict over the fundamentals of social organization (Gamble, 1993:10).

30 This was true, for instance, of her first budget in 1979, in which political expediency forced her to raise taxes instead of providing a promised tax cut, in order to proceed with her other economic commitments. Given that the preference of much of the electorate was not for tax cuts, this was a 'no lose' situation (Thatcher, 1995:169).

31 The five were: control of inflation and trade union power; restoration of incentives; upholding Parliament and the rule of law; supporting family life by a more efficient provision of welfare services; and strengthening defence (Butler \& Kavanagh, 1980:156; Thatcher, 1995:447). The contradictions inherent in the neo-liberal-neo-conservative mix will be addressed throughout this thesis, but particularly in chapter 6. 
Yet, public opinion research showed that, after a decade of Thatcherism, the population was in fact moving in the other direction, away from the values of Thatcherism (Crewe,1988, 1989). Crewe (1988) analyzed the attitudes of the British on core Thatcherite values as represented by policy initiatives and found that "the public has not been converted to Thatcherism - not to its priorities, nor to its economic reasoning, nor to its social values" (35). Crewe himself acknowledges, as do other analysts, that the "Thatcher governments have undoubtedly transformed the British political economy, overturned the political agenda, and permanently altered the social structure", but "this has been done without a cultural counter-revolution in the thinking of ordinary people" (241). Referring to Crewe's research, Jessop et al (1990:94) confirm that "changes in social and political values would seem a particularly weak dimension of Thatcher's revolution." But they go further and emphasize that popular reaction to Thatcherism, although it generally has not met with great success, must "not exclude shifts in everyday practices and routines with major ideological implications" (94). Jessop's view suggests a nuanced and ongoing ideological effect, that, when coupled with the diffusion of sites of power wrought by neo-liberal restructuring, will make it more difficult for the opposition to unravel (94-95).

\section{The Influence of the American New Right}

The course of the Thatcherite project in Great Britain owed much of its successes as well as its debacles to the changing global economy, which was dominated by the United States. The US was undergoing its own shift to neo-liberalism, which came into clear focus with the election of Ronald Reagan as president in 1980. The New Right 
political project in the US in itself is not an example that is easily transferred to other societies, because of the unique political strength of its religious Right, but the dominance of US hegemony in all spheres, particularly economic, has significance for both its international defence and diplomatic partner, Britain, and for peripheral countries, such as Canada and New Zealand (Jesson et al, 1988:18).

The global dominance of American hegemony depended on and was justified by its defensive role in containing expansion of countries with governments such as the Soviet government that did not share its interests, but "the underlying reason for the American-led military alliance system was the preservation of the capitalist market economy" (Warnock, 1988:57). The US bolstered its hegemony through economic and political power (such as the Marshall Plan) and military and economic assistance to developing world (as in the Korean War). This was made possible by the continued strength of the US economy, which began to falter only in the 1970s (but still outperformed other industrialized countries until the mid-80s) (59).

Beginning at this time, there was a distinct rightward shift in most liberal democracies, as economic instability became endemic (Girvan, 1994:215) ${ }^{32}$ Law and order, taxation and the economy were the common areas for state scrutiny, but there was also concern with foreign policy $(212,214) .{ }^{33}$ Reagan's pledge to restore America's standing in the world began a new phase of increased military spending, in stark contrast to his cuts in other areas of government spending (Warnock, 1988:59; King, 187:144).

\footnotetext{
32 Girvan makes reference to Ireland, France and the Netherlands to back up this point.

33 In the US, one historic signpost in this trend was the grass-roots movement in California that succeeded in passing Proposition 13, which limited that state's ability to tax citizens (Savoie, 1994:87).
} 
Reagan campaigned as an outsider running against the Washington establishment and big government, which he pinpointed as a central cause of the US's poor economic performance (Savoie, 1994:91). He was thus able to position the incumbent Democrats as the party of "state expansion and public spending" (91-93; King, 1989:140). He advocated a "new federalism" within a minimal state with some responsibilities off-loaded to local levels (King, 187:139), deregulation of the economy and contracting out to the private sector (Savoie, 1994:153). "Reaganomics" was a mixture of liberal and conservative economic theory, much the same as Thatcher's economic policy, with the exception of Reagan's reliance on supply-side economics as a guide for the American economy, while Thatcher relied on monetarism (King, 1989:141, 147) ${ }^{34}$ Supply-side economics argues that if government taxes are "excessive", then "reducing taxes will increase output without damaging the level of tax revenues accruing to the state" (143). It thus concentrates on the level of taxes as the monetary incentive that drives the economy. Government regulation of industry and social service benefits are also considered harmful to the economy (143).

Reagan began to implement his economic policy quickly, cutting non-defence public spending by $20 \%$ in his first budget and increasing the defence budget significantly over the years of his presidency (151-152). New deregulation policies allowed interlocking directorships of competing corporations, removed oil price controls, created guidelines that made it easier to merge corporations, weakened enforcement on worker health and safety, and substantially reducing environmental

${ }^{34}$ The main difference between the two policies, according to King, is that monetarism is followed by a short-run recession, while Reagan's policy of tight money supply was thought not to produce even a short-run recession. 
protection budgets (156-157). Over the first two years of Reagan's presidency, the US was in a recession, with negative GDP and double-digit inflation. As inflation dipped in 1982 and 1983, unemployment levels grew (148).

The intellectual framework for the New Right in the US was provided by the ideas of Friedrich Hayek, as promulgated through like-minded Republican politicians, such as Congressman Jack Kemp, and conservative economists, such as Arthur Laffer and Milton Friedman (142-144), and think tanks, such as the Heritage Foundation (Savoie, 1994:101; Stan, 1995:5). Reagan also looked to the private sector for ideas, advice and direction, and highlighted the role it could play in leading initiatives that would come its way as a result of minimalizing state interventionalism (Savoie, 1994:116). He emphasized the perspective of business as the role model for government operations; this became a feature of the conservative politics of both Thatcher and Mulroney $(123,125,145)$.

Reagan's presidency was a product of a general shift to conservatism in the 1980 election that brought him to power. This saw a swing to the Republican Party in Congress and an unusually strong Republican majority in the Senate (138, 140-141). Both were important to the coherence and unity of the Reagan project, conditions that eluded Thatcher before her election and during her first term of office. The Republicanled political institutions also played a large role in Reagan's re-election in 1984, as did the president's own personal popularity. Throughout this time, the Democrats remained weak in presidential campaigns; a contributing factor in their losses was the acceptance of conservative values by the American electorate, particularly in the area of economic policy, which left the Democrats without a differentiated platform (Girvan, 1994:214). 
As in the case of Great Britain, partisan identification was weakening and voters were swayed more easily by the election campaigns themselves.

The New Right project in the US was further strengthened when Bush succeeded Reagan as president, giving it three electoral mandates in a row for the Republicans. Bush continued to emphasize the New Right's salient issues: the economy, foreign policy and no tax increase. But the campaign was also fought on ideological values: Bush portrayed Democratic candidate Michael Dukakis as a liberal and un-American, juxtaposing moral liberalism against conservative moral norms (214215). Bush failed to be re-elected because his party was blamed for the poor economic conditions the country was experiencing, although a strong third-party candidate also cut into his support (216).

One of the reasons that Reagan's successes are hard to duplicate elsewhere is the prevalence in the US of a religious Right, which is a social, economic and structural force in American life and politics. Both the religious Right, which is estimated as including at least $25 \%$ of American adults (Jesson et al, 1988:19), and the co-existing libertarian Right are populist movements "built on economic distress" into a political force in the 1970s and 80s (Stan, 1995:5), "their politics aggressively offered in the public arena" (Jesson et al, 1988:19). Organized political action by the religious Right has been encouraged by its leaders and, by 1995, it had substantial control over Republican party constituencies in 31 states, as well as a voter-turnout strategy in a country where only $39 \%$ of registered voters have turned out for congressional elections (Stan, 1995:10). In this context, it is easy to see how conservative values and libertarian economic policies have permeated American thinking. Moreover, the strength of their 
successes in mobilizing their support around conservative issues reinforces the conservative mantra that 'there is no alternative' to market capitalism (Girvan, 1994:214).

The Reagan years (1980-88) coincided with the Thatcher years (1979-1990) and the two Prime Ministers forged a strong personal and state-to-state partnership. In addition to their conservatism, the US and Britain shared a common world vision in terms of foreign policy and diplomatic relations, based on a historic vision of themselves as world powers.

The influence of American New Right conservatism was also felt in Canada. Despite economic sovereignty and advanced development, Canada is a peripheral nation, that is, "closely integrated into the U.S. and Western centred, global economic order" and thus more open to international pressures than core countries (Parkland, 2000:5). Liberalization and globalization are two pressures that have been keenly felt in Canada, particularly with the US as a major trading partner and with the 'free' trade agreements between the two countries.

There were many ideological and intellectual linkages that flowed from the US and Britain to Canada, beginning with their Hayek-Friedman-led economics. Economists trained in American universities provided "external support... in the form of intellectual help." ${ }^{35}$ An important institutional linkage was involvement by conservative parties around the world in the International Democratic Union, which was founded by Thatcher in 1983 and which meets every six months (Thatcher, 1995:252). Another set of international linkages was through the European Democratic Union

\footnotetext{
35 In developing countries, this support included foreign aid, through the IMF and WB, "which played a key role in reform efforts in the 1980s" (Willamson, \& Haggard, 1994:565).
} 
(1978) and the Pacific Democratic Union (1982), alliances formed to counter a similar

Left organization, the Socialist International. Members of the EDU and PDU "exchange information about policies, techniques, strategies and organizational structures" and meet several times a year (Gustafson, 1986:178-179). Canada's Progressive Conservative party is a member of the PDU.

Through membership in other international forums, such as NATO, the G8 and OPEC, Canada's participates at the highest political levels in the proliferation of the neo-liberal global paradigm. Outside formal channels, the "Washington consensus" finds voice in such organizations as the Institute for International Economics (IIE). The IIE's contribution to neo-liberalism is significant through its policy debates and analytical work on market-led reform, notably in The Political Economy of Policy Reform, in which it develops a framework for successful market-led reform. Authors Williamson \& Haggard (1995) states that as a group of economists, the IIEE has

gone beyond the development of policy agendas to make a conscious effort to sell the resulting ideas to the policy community...[W]e have decided that what made sense according to our own conception of the general social interest, and then tried to persuade politicians, policymakers, and the body politic that the benefits of that course of action would exceed the costs (527).

\section{The Construction of Neo-Liberalism in New Zealand}

The New Zealand model found influence among neo-liberal adherents in Canada and played a role in constructing the debt crisis that has sparked neo-liberal reform and a developing hegemonic consensus federally and in provincial jurisdictions. It is also significant because it demonstrates how New Zealand streamlined and strengthened the 
British model of neo-liberalism into a more consistent and powerful political and ideological force that was taken up by Alberta and Ontario.

As in many Western industrialized countries, the 1970s in New Zealand was a period of social change which could be said to constitute an organic crisis (Jesson et al, 1988:26). Internationally, the trend to globalization of economic and political power makes New Zealand's vulnerability as a peripheral state more pronounced (Kelsey, 1994:192; Parkland, 2000:2). Internally, there was a steady economic decline, with a wage and price regime from 1982 to 1984, failed government policies to arrest the decline, low productivity and high wage growth (Oliver, 1989:21). These seemingly irreconcilable conditions opened up a political space that allowed neo-liberalism to enter (Neilson, 1998:65-66).

Market liberalization was not new to New Zealand politics (Easton, 1989a:127), and first movement towards restructuring did not seem at first to be incompatible with Keynesianism-corporatism. ${ }^{36}$ But, by the time of the 1984 election, the prevailing orthodoxy was disintegrating, particularly under the influence of the Treasury, a ministry of the government and its pre-eminent economic advisory body, which greatly influenced the paradigm shift to the new consensus (Goldfinch \& Roper, 1993:51-52; Whitcombe, 1989:157). With the encouragement of the IMF and the World Bank (Nagel, 1998:229), it had already adopted the private sector model as a new analytical framework (Easton, 1989a:127). An important reason for the initial exploration and acceptance of market reform options by the Treasury was the lack of other views

\footnotetext{
36 Influential government reports had indicated that fiscal policy wasn't effective to cushion the economy's ups and downs, and that the public sector was overloaded. In addition, the Reserve Bank (a macro-economic research agency) called for an independent monetary policy, a self-adjusting exchange rate and deregulated interest rates (Bertram, 1993:40).
} 
expressed that might lead to other policy solutions (129); there seemed to be no credible alternative to market reform (Neilson, 1998:55; Easton, 1989b:182).

The Treasury was not the only influence on state economic policy, but was part of a "tight nucleus of change agents in power positions" (Nagel, 1998:56). These change agents included the Business Roundtable, the Reserve Bank and the Centre for Independent Studies, ${ }^{37}$ which represented "a resurgence of the intellectual right... as manifested in the burgeoning right-wing private sector think tanks" (Castles et al, 1996:9). Before the 1984 election which brought Labour to power, "a strong body of thinking had consolidated within Treasury and the Reserve Bank in favour of economic deregulation, exchange-rate flexibility and a move to a monetary policy modelled on the Thatcher government's medium-term financial strategy of the early 1980s" (Bertram, 1993:43).

Implementation of the new government's economic policy was eased by the unicameral parliamentary system in New Zealand in which cabinet has considerable independence from its organizational and social bases (Neilson, 1989:55). There was little consultation beyond key members of Cabinet even with other members of Cabinet (Easton, 1989b:172-173). The power of cabinet was supported by the two-party, 'firstpast-the-post' political system that has been called an "elective dictatorship" (Mulgan, 1992:530) because of the way it excludes completely the votes, and therefore the voices, of parties other than the government. Backed by a parliamentary majority, the legislation was able to disregard public input and the parliamentary process and

${ }^{37}$ The Business Round Table (BRT) is a self-appointed group of corporate executives representing the largest and most internationalized fraction of New Zealand-based capital (Nagel, 1998:55). The Centre for Independent Studies is a libertarian think tank which conducts research, produces publications and organizes seminars on market liberalism. The Reserve Bank's economists overlap with the Treasury and both develop monetarist and other neo-liberal policies. 
convention or were "formulated outside Parliament by the executive by way of regulations or orders in council" (Kelsey, 1994:187).

In 1987, Labour won re-election with an increased majority, owing its victory to the collapse of the third party vote, a more polarized urban-rural split, the loyalty of core Labour voters (Levine \& Roberts, 1989:443), and the "coalition of minorities" it had amassed by appealing to different sectors on different issues (Nagel, 1998:255$256) .{ }^{38}$

There was much criticism and opposition to the government's restructuring policies themselves, but also the unorthodox manner in which the government proceeded through the policy cycle. From the outset, it rejected New Zealand's traditional consultative and cooperative approach to lobbying and consensus (Cleveland, 1985:234-235; Jesson, 1992:367) and "adopted an attitude of aggressive resistance to all sectional interests" (Mulgan, 1992:526). The government, like Thatcher's before it and Ontario's after it, saw interest groups as attempting to "gain unjustified privileges", so there were few consultations on major policy proposals (Vowles, 1989:291), while lobbying activity by business increased (Du Fresne, 1989:313-314).

The government was aided in its massive restructuring efforts by the unique media system in New Zealand; it has a small market with relatively few media, making it easier to effect controls (Atkinson, 1994b:150). The government privatized both public radio and television, turning them into "state-owned enterprises for profit" and

38 These strategic alliances are unstable, but can also be reconstituted. This ability to adapt has become a feature of neo-liberal governments, and is used often in Ontario (Neilson, 1998:58). In New Zealand, as an example of such an alliance, Labour's middle-class electoral base, which was strongly in favour of progressive social policies, was appeased by its nuclear-free stance. 
media deregulation was swift (148). The introduction of new information technology into the country was the economic and political driving force behind much of the restructuring (Atkinson, 1989:85). Atkinson's (1994) study of New Zealand television after deregulation showed a tendency to "morselization" (smaller sound bites and shorter news items) and "depoliticization" (less context) in news coverage (152). Government and election communications practices also changed after 1984. Public opinion research used for political purposes is a recent development in New Zealand, starting around 1970 (Bean, 1988), but by the 1988 election, no less than 40 polls were published (Atkinson, 1989:88). In that election, both the opposition National Party and the government used American campaign expertise, the National Party in campaign techniques and technology borrowed from its Republican colleagues (93) and the government in public opinion expertise (88). Inside government, a Communication Strategic Committee was formed to coordinate and centralize communications efforts and consultations with the public became highly controlled "stakeholder seminars" (Atkinson, 1994a:199, 201).

Part of the international interest in the New Zealand 'experiment' has been the breadth of the restructuring of state and society achieved within only six years under Labour (Easton \& Gerritsen, 1996:224). The OECD called the New Zealand reforms "the most comprehensive economic reform programme undertaken by any OECD country in recent decades" (Nagel, 1998:224). The government changed the policy cycle by limiting consultations, but it also changed the legislative cycle by creating a "blitzkrieg"-a policy approach attributed to Finance Minister Roger Douglas that 
involved a policy goal radically different from the existing configuration, to be attained in a short period, following a surprise announcement and a very rapid implementation... [E]ach policy initiative was different in detail, but at its heart was the aim to transform profoundly some substantial aspect of the economic and social framework (Easton, 1994:215).

The blitzkrieg also changed government communications and had an impact on media coverage. (This will be discussed in chapter 4.) Blitzkriegs introduced a number of major policy initiatives in different sectors, including the public sector (1987), education (1988), income tax (1988), health reforms (1990) and labour contracts (1991). Douglas's strategy is detailed in his autobiography, but it can be summarized as 'hit hard, hit fast, don't blink' advice that, as we will see, was followed in Alberta and Ontario (Douglas, 1993:ch. 10).

By 1990 , public confidence in the government had eroded substantially, with only $4 \%$ of New Zealanders polled expressing confidence in it (down from $33 \%$ in 1975) (Nagel, 1998:252). ${ }^{39}$ The country's economic indicators were not showing the expected turnaround and rapid change had brought social instability $(228,230)$. In the same year, a general election brought the conservative National Party to power. The new government continued with the reform agenda. Indeed, a surprising feature of the New Zealand reforms, and one that is much commented on by both Left and Right, is that the government that instigated the reforms was led by a social democratic party. The supposition was that it would be antithetical for a social democratic party to initiate or support neo-liberal reforms.

\footnotetext{
${ }^{39}$ By $1990,41 \%$ believed the government was headed in the wrong direction (up from $20 \%$ three years previously), with a further $32 \%$ saying the direction was right, but the pace of change was too fast (Nagel, 1998:250).
} 
In his study of OECD countries undertaking the neo-liberal reform of privatization of state structures in the 1980s, Boix $(1997: 473,495)$ shows that governments at both ends of the political spectrum undergo reforms and that partisan composition, the internal structure of cabinet and other institutional arrangements shape the strategies of reform. Under social democratic or socialist governments, large privatization does not regularly occur, but can when the country is facing poor economic performance and when there is political cohesion within cabinet (492). Under conservative governments, the likelihood of a full range of privatization is high, regardless of other circumstances, and only good economic performance will limit the reforms. So, although New Zealand is the only social democratic/socialist country that privatized extensively, Sweden, with a more fragmented cabinet, underwent small privatization, and Australia and many other countries with social democratic governments undertook minor reforms (486).

Boix's analysis focused on privatization only, but Schwartz (1997) has analyzed the content and implementation of neo-liberal policy reform in general. Schwartz concludes that "left governments in general are probably more likely to pursue and succeed at the reinvention of government [public sector restructuring], while stinting fiscal balance, while right governments are more likely to achieve short-run fiscal balance at the expense of successful reinvention" (1). This is reflected in the case of New Zealand; the Labour government emphasized public sector restructuring and when the National Party continued with the reforms, it emphasized fiscal balance (2).

In addition to its streamlining of the implementation of the neo-liberal model, the significance of New Zealand's turn to neo-liberalism is that, at a time when ideology 
led political change, those embracing change avoided theoretical identification and claimed instead to espouse an eclectic position which they described in pragmatic terms (Bertram, 1993:47). Neilson (1998:51-52) has described New Zealand's response to the economic crisis as a "non-hegemonic restructuring strategy", as opposed to "active hegemony." In a non-hegemonic restructuring strategy, the state recognizes that immediate needs of capital conflict with the immediate interests of citizens and responds to the crisis by pursuing "a new institutional framework without an active hegemonic base" (52). The restructuring proceeds before a hegemonic bloc is constructed in the hope that new public understanding or hegemony will emerge from it. Thus the reforms initially require only "a ruling hegemonic nucleus" and "key change agents" (52), but an ongoing war of position is needed to legitimate and maintain it. In such a restructuring strategy, "an active hegemony only becomes a final goal of the project, rather than the mandate to pursue the project in the first place" (53). New Zealand's project over time and after heavy restructuring became hegemonic, while Thatcher's - by contrast, signaled clearly by an ideological election manifesto and campaign offering a clear alternative-proceeded as if it already had the mandate, yet did not necessarily reach its goal of active hegemony.

\section{The Rise of the Right in Canada}

Like New Zealand, Canada is a state on the periphery, variously described as a hinterland, a dependency, a go-between nation, a semi-satellitic country and a resourceexporting economy (Parkland, 2000:5). It is much more vulnerable to international pressures and changes than many other Western industrialized countries and has been 
long subjected to the influences of powerful core countries, such as the United States and Great Britain (Langille, 1987:43), but this has allowed it to develop state-centred policies aimed at achieving more autonomy, diversified development and redistribution of incomes, and thus also differentiating it from the Britain and US. In many ways-in wages, consumption patterns and class structures, for example-it is virtually the same as core countries (Parkland, 2000:5). Yet, unlike the US, it had no extensive, politicized and heavily-resourced religious Right, ${ }^{40}$ unlike Britain it had no strong and politicized trade union movement and, unlike both countries, it had a different foreign policy focus, less hegemonic and more in harmony with its domestic brokerage politics.

Canada's post-war economic strategy combined Keynesianism and continentalism, along with nationalist industrial policies (Ernst, 1992:109), and, like other capitalist countries in the late 20th century, it felt the pressure of maintaining a complex, interventionist state at a time of national and international economic instability and increased private sector activism (109; Langille, 1987:43). The emergence of the new business agenda of the 1970s was thus "linked to a capitalist offensive crystallized in the Canada-US Free Trade Agreement as a response to the profits squeeze forced on capital by relatively militant working class and a state 'which appeared to be growing beyond its control'" (Langille in Ernst, 1992:110).

This shift also revealed itself in a change of government, from the Liberals who had been in power from 1963 to 1984 (with a brief interregnum in 1979-80), to the Progressive Conservatives. Despite the move to the Right and the ideological

\footnotetext{
${ }^{40}$ In the past, Canada has had provincial political parties with strong religious overtones, such as the Aberhart and Manning governments in Alberta. Quebec politics as well has been influenced heavily in the past by the Catholic Church. Until the rise of the Reform Party in the West, religion has been latent in Canadian politics. The US's religious Right, on the other hand, is huge, increasing and politically powerful.
} 
governments in Great Britain and the United States, Brian Mulroney's Conservatives campaigned in traditional pragmatic Canadian brokerage fashion, "seeking to please everyone with vague promises, few specifics, and no meaningful policy principles" (Bradford, 1999:40). His victory was built on a coalition of Westerners alienated from both the Conservative party and the governing Liberals and gains made in Quebec, fulfilling the promise from his election as leader (Simpson, 1984:369). Brokerage politics as manifested in Canada, in fact, traditionally reflected continuity rather than change by virtue of the limited mainstream political spectrum, large social cleavages, the imperative of nation-building and a propensity in elections to "broker a coalition of supporters" (Clarke et al 1996:15-16). In such a situation, the mandate given the victorious party is not necessarily a policy mandate. In the 1984 election campaign, Mulroney did state his opposition to the Macdonald Commission, which was struck by the previous Liberal government, free trade and the welfare state. But when the Macdonald report was actually released in 1985, the Conservatives "used [its] neoliberal paradigm to devise a coherent governing agenda" (Bradford, 1999:40).

In Canada, the report of the Macdonald Commission on the economy presented its findings as "the only policy paradigm that could feasibly be implemented" (Bradford, 1999:40). Under the Canadian political system,

[a] return to markets required neither political cultivation of cross-class or interregional coalitions, nor expanded administrative capacity. To the contrary, neoliberalism's anti-political and anti-statist qualities allowed Canadian governing parties to proceed with their own brokerage variant of Mrs. Thatcher's frank claim to the British electorate that 'there is no alternative' (45). 
Yet, federal election campaigns of the period were not referenda for systemic change; instead, governments-to-be either misled voters or simply did not discuss their policy intentions (Warnock, 1988).

Writing in 1989, prior to the Klein and Harris neo-liberal governments, Jenson found the literature of post-war compromise difficult to apply to Canada. This may partially account for the lack of aggressive neo-liberalism federally while close allies and partners, Great Britain and the United States, had embraced the new paradigm. Jenson (1989:70) contends that Canada is "'different' but not 'exceptional'," that is, our regime of accumulation was Fordist, like many countries, but that our Fordism was economically and politically different. Canadian Fordism takes a regulation or stabilization approach which balances often contradictory social relations within broadbased political activity. This "permeable" Fordism "ordered collective identities around a discourse of nation-building, rather than based on a compromise wrought in partisan, ideological, class-based politics" $(72,81)$, with all three major political parties providing support. Thus, Canada developed a brokerage system of politics that was tied to the short-term and pragmatic as opposed to ideological and divisive (Clarke et al, 1996:22).

Neo-liberalism in Canada thus did not burst onto the political scene as it seemed to in Great Britain and New Zealand. Instead, the account above shows that Canada drifted towards neo-liberalism under what could be called 'stealth' politics. Although some of the preliminary battles between capital and labour had already been fought and lost by the latter under Liberal governments, it was under the Mulroney government that back-door restraint was implemented. The capital-labour battles had conditioned the 
public, as had a decade of "concerted and constant propaganda [from government and business interests] about the supposedly disastrous implications of the national debt and a host of piecemeal changes to social programs" (Browne, 2001:6).

The first reference to 'stealth' politics as a characterization of the Conservative style of restraint was in 1990. It referred to "regressive changes in the rhetoric of equity in an attempt to convince Canadians that tax increases are tax cuts and that benefit cuts are benefit increases" (Gray, 1990:20). Social policy by stealth camouflaged how one policy change worked at odds with another. Its effect, if not its purpose, was that it "confuses the electorate and so insulates itself from criticism" (17) and "imposed on Canadians without their knowledge, consent or understanding" (Caledon, 1998:2). ${ }^{41}$

But if neo-liberalism did not come suddenly to Canada, it only appeared to do so in Great Britain and New Zealand through visible changes at election time. In reality, neo-liberalism was not yet a coherent ideological or political strategy or project (Isin, 1998:174), but a transition that was taking place "in an imperceptible manner, like continental drift" (Bourdieu, 1998:5). At best, it was an amalgam of competing discourses, with its conservative authoritarian and economic libertarianism facets breaking away from the social democratic hegemonic bloc and struggling with each other to secure their own leadership (Jesson et al, 1988:26). It was not

underpinned by a coherent and elaborated political rationality that they then sought to implement, much less one that identified bureaucratic and professional power as a key problem... but gradually these diverse skirmishes were rationalized within a relatively coherent mentality of government that came to be termed neo-liberalism (N. Rose, 1996:53).

41 The Caledon Institute is one of the few research institutes that promotes progressive state social policy. 
The experiment of neo-liberalism confirms Bertram's (1993:31) thesis that economic theory is less scientific than political, gaining sufficient intellectual cohesion and ideological acceptance only as it is manifested politically over time.

The economic crisis in Canada was, to some extent, inherited from the United States in the sense that we are influenced by our largest trading partner and closest geographical ally in a world system in which Canada remains on the periphery. But, Canada's post-war history and political system are different and so our crisis took on its own form (Jenson, 1989).

Canada's crisis of the 1970s showed how vulnerable it was to the political and economic up and downturns of the US, but it also floundered "in the face of new and profoundly fragmenting collective identities based on language and region, fostered by province-building governments" (Jenson, 1989:85). Biculturalism, regionalism and nationalism, through heated constitutional debates and the institution of nationalist programs such as the National Energy Program (Clarkson, 1993), were the issues that characterized, and then fragmented, with the deepening recession as a necessary condition (Jenson, 1989:86-87). Thus, Canadian neo-liberal restructuring, when it came, did not have the ideological or partisan pattern or the strength shown in previous jurisdictions grappling with the new paradigm.

By 1988, the divisive public battle on free trade with the United States made the general election that year into a referendum on the issue. The two main parties opposing free trade - the Liberals and the NDP—captured a majority of the popular vote, but lost the election to the Conservatives. With their second majority win, the Conservatives were in a position to implement free trade and other neo-liberal policies, 
such as the destabilization of labour and the tightening of welfare state provision. The free trade battle and subsequent agreement (the FTA) was a portent of battles to come in terms of the political alignments and divisions it revealed. Free trade was supported by the major (conservative) think tanks, business groups and banks, while the agreement was opposed by popular sector groups representing labour, women, anti-poverty and the environment (Warnock, 1988:116-117) ${ }^{42}$ In addition, the Action Canada Network in particular had conducted a strong and influential cross-Canada campaign against free trade during the election, in the process positioning itself at the start of a move to coalition building in Canada (Bleyer, 1992:107).

The legitimacy of the Conservatives was helped by the upswing in the economy shortly after they took office, which by the end of the decade saw the unemployment rate drop to under $8 \%$, as compared to $11.9 \%$ in 1983 (De Mont \& Lang, 1999:27). As federal governments have done before them since the late 1960s, they continued to run deficits (Klein, 1996:34, 132). Public concern with the deficit was only low to moderate, with a 1989 Gallup poll showing $31 \%$ of Canadians very concerned, but a quantum shift took place by 1994 , when concern rose to $50 \%$, by which time "the deficit reduction agenda had now transcended political affiliation, drawing from all parties, including the NDP" (De Mont \& Lang, 1999:31-32).

Although he implemented many neo-liberal policies, Mulroney did not have a coherent Right program. His economic policies followed the conservative trend, demonstrating his own ideology and his interest in strengthening his alignment with US President Reagan. Like Reagan, Mulroney was an outsider (Simpson, 1984:361)

42 These pages in Warnock contain lengthy lists of free trade supporters and opponents. 
running against the political establishment and his policies were often a carbon copy of Reagan's agenda—a new federalism, deregulation and downsized government (Savoie, 1994:91, 103). In particular, he had a strong privatization agenda that crystallized in the 1985 budget, in which it was announced that "crown corporations with a commercial value but no ongoing public policy purpose will be sold" (Laux, 1991:289). In practice, although crown corporations, mixed enterprises and subsidiaries were sold, the level of privatization was very low compared to the concurrent privatization in Great Britain and New Zealand (306-309). ${ }^{43}$ But Mulroney was also responsible for many initiatives that were anathema to the new Right: liberalization of immigration and criminal justice systems, establishing regional agencies to encourage development with government money, and back-handed tax increases (de-indexation of personal income tax brackets and credits and establishing high income surtaxes). Most importantly, he ran among the highest deficits in Canadian history (both as an aggregate and as a percentage of GDP) (De Mont \& Lang, 1999:23).

Although Mulroney may not have fit the description of traditional conservatism in Canada—described as maintaining "the importance of balance between freedom and responsibility, for limited government but does not dismiss the importance of government and other institutions, favours broad pluralism in society, favours law and stability, but no interest in control over human nature" (Segal, 1997:3)-neither was he a neo-liberal. Instead, he kept a strategic balance, "breaking with the previous paradigm, but unharnessed and incoherent, as were all the early attempts at hegemonic change" (De Mont \& Lang, 1999:23). Clarkson (1993) says Mulroney's party label—

43 Those privatized between 1985 and 1988 included: De Havilland Aircraft of Canada Ltd., Canadair Ltd., Teleglobe Canada, Air Canada, and Canada Development Corporation. 
Progressive Conservative-defined his contradictory political position: "[H]e claimed to be committed to preserving the social programmes of the welfare state as a 'sacred trust', but he was also the spokesman for business interests impatient with the constraints imposed on them by the allegedly interventionist Liberal government" (11). The New Right found a stronger voice in the 1980s and 90s in the Reform Party, the Business Council on National Issues and the C.D. Howe Institute and provincial leaders like Alberta's Premier Ralph Klein and Ontario's Premier Mike Harris (De Mont \& Lang, 1999:22-23).

The Reform Party as constructed by then leader Preston Manning has been called "a powerful form of identity politics that challenges special interests and constructs (while championing) the 'common sense of the common people"' (Patten, 1996:96). It is an extension of New Right agenda which has been imported from the US and Great Britain, as well as finds its history in the mainly Western Canadian politics of 'niche' or regional Social Credit, Confederation of Regions and Christian Heritage (De Mont \& Lang, 1999:25). The Reform Party seeks to redefine common sense and entrench New Right politics as the Canadian mainstream. It is not only populist, but also libertarian and socially conservative (Patten, 1996:96), and as such is a truly neo-liberal movement. Reform's populism is centred in the belief that increasingly powerful interests (such as the Left and others such as the bureaucracy and minority interests that maintain the welfare state) threaten ordinary Canadians and that the welfare state itself threatens the social order and political values that are fundamental to their way of life (104-106). Reform is suspicious of the new collective 
identities that it sees as replacing the nationalist discourse and its success depends on its ability to bring people into politics as 'ordinary Canadians.' 44

Reform, like its then leader Preston Manning, comprised eclectic views, drawing from different intellectual traditions and individuals, including the religious Right (De Mont \& Lang, 1999:24), ${ }^{45}$ but party policy exhibits the potent mix of classic liberal economics and moral authority on social issues that Thatcher relied on to come to power in Great Britain. Reform policies, still maintained by its successor, the Canadian Alliance, include: tough criminal justice policies, opposition to state-run day care, shifting provision of social services from government to churches and charities, expenditure reduction, a flat tax and tax reform, guaranteed annual income, and decentralized government with unconditional federal transfers. Much like the fate of some of the New Right social policy in Britain and the US, Reform strategically downplayed its social agenda after the 1993 election, as it was seen as less supportable by Canadians $(26,29-31)$.

The question has been asked as to why the Progressive Conservatives did not fill the widening space on the political Right. Mulroney was antipathetic to big government and intended to reform the public sector (Savoie,1994:94), ${ }^{46}$ but the Conservatives were still seen to be part of the problem: "Reformers represent the former right wing of the federal Tory party who had become disillusioned with the centrism of the Mulroney government and, in particular, its failures to reduce the deficit and cut taxes... Manning

\footnotetext{
44 Interestingly, the phrase "ordinary Canadians" was used as a political message during the 1984 election by the New Democratic Party, a small but interesting illustration of the vacating of populist space by the Left since that time.

${ }_{45}$ De Mont and Lang (1999) say former Reform MP Stephen Harper, now Canadian Alliance leader, left the Reform Party because of its "ideologically impure direction under Manning" (24).

46 The day after coming to office, Mulroney announced a task force to review government programs, followed several days later by an announcement of $\$ 4.2$ billion in spending cuts.
} 
walked into a political void created by the lack of real, focused attention to [the deficit] by the established opposition parties and sitting governments" (De Mont \& Lang, 1999:25). In this political void, Reform positioned itself as the only party that had fiscal conscience and would not pander to powerful special interests, in effect, that it was the "true voice of fiscal conservatism and neo-liberalism" (1996:115).

A new, inexperienced leader (Kim Campbell), an unorganized party apparatus and the shift of the Quebec wing of the party to the Bloc Quebeçois under Lucien Bouchard spelled disaster for the Conservatives in the 1993 general election, but their larger political problem was the strength of the populist Reform Party showing in the West, which threatened base party support. Back in government, the Liberals continued and consolidated the piecemeal neo-liberal program begun by the Conservatives, reneging on campaign promises and signing NAFTA, making radical deficit reduction its single economic priority and abandoning industrial innovation and skills training (Bradford, 1999:41-42).

By 1996, under the Liberals with Paul Martin as Finance Minister, the deficit battle was effectively over, due to spending cuts in the tough 1995 budget and a booming economy. The latter effectively robbed Reform of its main platform, so it concentrated on debt reduction and tax cuts/tax reform, however, it made no new gains in the 1997 election. Lack of internal discipline and continued battles with the Conservatives have suggested that Reform has lost much of its vigour as a political force, even in its new incarnation as the Canadian Alliance.

De Mont and Lang (1999) have commented that the significance of the Reform story is that the party marked "the first time in living memory that a political party 
spelled out a clear neoconservative economic program, although such an agenda had not been road-tested by any of the federal, or for that matter provincial, parties (28)." Alberta became the first province to provide that road-test.

The Progressive Conservative Party has been in government in Alberta since 1971 with little opposition in the legislature in recent years. As virtually a one-party government during these years (Taft, 1997), it relies on "an electoral coalition of various class elements, economic interests, and regional groupings" (Brownsey, 1999:117-118) more than do some other provinces. Resource-rich, Alberta traditionally relies on oil and gas revenue as well as taxation revenue to fund the state's interests and, like most welfare state governments, has built a large state apparatus to support it. By the 1980s, however, Premier Bill Getty reduced the level of public spending when declining resource revenue and large subsidies to the private sector showed steady increases in debt. Getty's cuts put Alberta spending below the average for all provinces two years before Ralph Klein came to office (Taft, 1997:3, 27).

In late 1992, Klein was elected leader and became premier. Within weeks, he appointed an independent financial review commission, a tax reform commission and round-tables on the upcoming budget (Lisac, 1995:81-82). The first roundtable featured a showing of a CTV program on New Zealand's experience with restructuring, which said the country had "hit the debt wall", implied it could happen to Canada and said "there was no choice" but to undertake neo-liberal reform (87; Klein, 1996:81). The review commission reported two months later that Alberta had a structural deficit (in which revenues are permanently smaller than expenditures) (Lisac, 1995:88). Klein fought his first election in June 1993 as a candidate for change, change that would 
control a crisis for which the only solution was getting skyrocketing government spending under control (108; Dobbin, 1998:220-221; Adam, 2001). Although he won a majority, it was not an easy victory: There was a surge in voter turnout, the popular vote for the Conservatives was close to the Liberal popular vote, and the Liberals formed a strong opposition (Lisac, 1995:108). Klein was swift to move on his commitment to change. The tax reform commission reported that a competitive tax system in Alberta was important for global competitiveness; this was followed by a budget that cut almost $\$ 1$ billion of spending per year for four years in order to balance the budget. Two-thirds of the cuts were in the education, health and social service portfolios $(182-183,185)$. Over 18 months, cuts were announced to $20 \%$ of the health budget (Taft, 1997:27).

Klein's neo-liberalism was influenced by Thatcherism, Reaganomics and Rogernomics, through think-tanks, media reports and speech tours by market liberalization advocates such as British consultant Madsen Pirie and former New Zealand Minister of Finance Roger Douglas (Dobbin, 1998:201, 265). ${ }^{47}$ It was reinforced by Canadian advocates, such as financial journalist Diane Francis, the National Citizens' Coalition and the Fraser Institute (Lisac, 1995:17).$^{48}$ In 'road-testing' neo-liberalism, Klein took its ideology and applied it in political practice, following Douglas's strategic rules and improving on them: 'hit hard, hit fast, don't blink' incorporated the lessons learned and accelerated them. It also demonstrated that neoliberal reforms were transferable to a Canadian environment.

\footnotetext{
47 Douglas also spoke to the 1991 Reform Party convention.

48 The NCC distributed Pirie's privatization guides to Canadian legislators and Klein gave them to his caucus (Dobbin, 1998:200). The Fraser Institute awarded Klein it's annual prize for the best fiscal performance of any North American government in 1994 (Taylor, 2001:17).
} 


\section{The Construction of Neo-Liberalism in Ontario}

It was in Ontario-Canada's industrial heartland (Bradford, 1998:540)—rather than in a politically alienated province like Alberta that the ready transferability of neo-liberalism became apparent as a portent of general change. The province's history does not signal such a paradigm shift. Ontario politics was known for its bland centrism, informal links with business and cautious policy making over a long period (since 1943) of Progressive Conservative governments (543).

Bradford (1998:543) says the centrally located Ontario was the one province that did not have a regional identity and instead was tied to the nation-building goals of the federal government. Ontario's politics and prospects continue to be linked to the federal political environment. Federal spending cuts and deficit reduction by Mulroney and later by his successor, Jean Chrétien, marked a gradual change for federal-Ontario relations throughout the 1980s. Over time, federal government funding of the province's health care costs were reduced from about $50 \%$ to $11 \%$ by 1998 and federal transfers dropped from $17 \%$ to $8 \%$ in the same period. Although funding, however diminishing, was still tied to strict conditions, the cuts and the deficit crisis had undermined Ottawa's ability to influence social policy and allowed the provinces to shape their own social services and their own economic agenda (Ibbitson, 2001:157, $166,190)$. But early in the 1980 s, this shift in federal-provincial relations was only hinted at.

Ontario was further characterized by its ability to balance interests, including those inherent in Red Toryism-combining social progressiveness and economic conservatism - and forge "stable electoral coalition[s] of free-enterprise-oriented 
interests and state-centred interests" (Woolstencroft, 1997b:366). In effect, it practised the brokerage politics that worked so well in federal politics, responding to changing concerns and avoiding ideological conflict (Woolstencroft, 1997a:366). Bill Davis, premier of Ontario for 14 years until 1984, summed up Ontario politics by saying "the average Ontarian is a moderate. He is not to his left or to his right. That has been the history of Ontario. Success lies in the middle of the political spectrum" (Speirs, 1986:45). That moderation, along with order, stability and continuity, kept the Conservatives in power: ${ }^{49}$ "[T]he ethos of Tory Ontario combined deference to state authority with a predisposition against change and innovation... Its political culture "did not value decentralized policy initiative, horizontal collective action networks, or social partnership" (Bradford, 1998:543). Ontarians also had an expectation of prosperity, drawn from the affluent post-war years (Ibbitson, 2001:161), and this led them to be complacent about their society and their government (only $58 \%$ of those eligible voted in the 1981 election that was Premier Bill Davis's last) (Speirs, 1986:xviii).

In practical terms, the continuation of the Conservative hegemony in Ontario also depended on the existence of two opposition political parties (xviii). The two parties divided the opposition vote to allow the Conservatives to win, but they also had pockets of strength in different parts of the province with potential for more and could well be placed to win an election (Woolstencroft, 1997b:367).

Although it seemed that the Conservatives would reign benignly in Ontario for a good many more years, there were signs of change. The external environment had

\footnotetext{
49 Spiers (1986:xviii) also mentions the "counterweighting" tendency of as many as one-third of Ontario voters who switch their votes to the Liberal federally while voting consistently for the Conservatives federally.
} 
shifted. The federal government was opening the door to free trade and the global economy was encroaching on Ontario's economic stability. The 1985 leadership convention in Ontario to replace Davis "coincided with the acceleration of structural transformations in the global economy, which placed intense pressure on Ontario's mass production manufacturing base" (Bradford, 1999:544). Both the workforce and the economy itself were at risk in the branch plant industrial structure upon which Ontario relied.

Even before globalization began to destabilize the economy, world oil shortages had shifted economic power from Ontario to the West (Speirs, 1986:12). Internally, there were also indicators that the social stability Ontario had enjoyed was flagging. Over the 42 years the Conservatives were in power, Ontario had become an "urban, polyglot, and multiracial" society (xxi). The Conservatives, by comparison, seemed out of touch, especially when they elected a new leader, Frank Miller, from the right of the party (58). This left a vacuum in the middle of the political spectrum-where the Conservatives usually sat (77)-and in the 1985 provincial election that followed, Ontario elected more Liberals than Conservatives, but not enough to form a government. The NDP held the balance of power and, after negotiations, agreed to support the Liberals for two years in return for support for a list of policies they drew up (Speirs, 1986:ch. 5).

The 1985 election began a period of flux in Ontario politics that could be construed as an organic crisis. Although the government had not changed in 42 years, it was about to change three times in one decade. This has been interpreted as a "consistent search on the part of electors for solutions to the persistent economic 
Table 1

Ontario Provincial Election Results, 1981-1995

\begin{tabular}{|c|c|c|c|c|c|c|c|c|}
\hline \multirow[t]{2}{*}{ Year } & \multicolumn{2}{|c|}{ Conservatives } & \multicolumn{2}{|c|}{ Liberals } & \multicolumn{2}{|c|}{$\begin{array}{l}\text { New } \\
\text { Democrats }\end{array}$} & \multicolumn{2}{|l|}{ Other } \\
\hline & Seats & $\%$ Vote & Seats & $\%$ Vote & Seats & $\%$ Vote & Seats & $\%$ Vote \\
\hline $\begin{array}{l}1981 \\
1985 \\
1987 \\
1990 \\
1995\end{array}$ & $\begin{array}{l}70 \\
52 \\
16 \\
20 \\
82\end{array}$ & $\begin{array}{l}44 \\
37 \\
25 \\
24 \\
45\end{array}$ & $\begin{array}{l}34 \\
48 \\
95 \\
36 \\
30\end{array}$ & $\begin{array}{l}34 \\
38 \\
47 \\
32 \\
31\end{array}$ & $\begin{array}{l}21 \\
25 \\
19 \\
74 \\
17\end{array}$ & $\begin{array}{l}21 \\
24 \\
26 \\
38 \\
21\end{array}$ & $\begin{array}{l}- \\
- \\
- \\
1\end{array}$ & $\begin{array}{l}1 \\
1 \\
2 \\
7 \\
4\end{array}$ \\
\hline
\end{tabular}

Source: adapted from Drummond \& MacDermid (1997) and Tanguay (1997)

problems they experienced in the 1980s and 1990s" (Rachlis \& Wolfe, 1997:331). Several broad changes in electoral politics were beginning to manifest themselves in Ontario. As in Great Britain, New Zealand and other countries, electorates are more volatile than they were a generation ago. Partisan dealignment and class or group dealignment open up space in elections, so "individual citizens react to political events and movements with fewer attachments to intermediary social organizations" (Woolstencroft, 1997a:39). In addition, voters are now "oriented much more towards leaders and issues, [and] are susceptible to the parties' extensive electronic advertising campaigns" (39).

The Liberal-NDP Accord period "witnessed extensive policy innovation and government activism" (Cameron \& White, 2000:12). The accord called for reforms of the legislature, including several initiatives for government accountability to the public. 
It also laid out the government's legislative agenda, including many initiatives that strengthened rights and benefits of various sectors of the public (Speirs, 1986:164). ${ }^{50}$ The accord was significant for the Liberals because it gave them the policy platform they lacked, a legislative program and a timetable. Their first budget gave them the image they needed as "progressive but prudent" managers of the economy (179-180). In a decade when the next federal election in 1987 and voters gave the Liberals a majority government, economic growth and consumer confidence were higher than they had been (Gagnon \& Rath, 1991:39).

Immediately after the 1987 election, the New York stock market crashed, followed by the Toronto stock exchange, and an economic downturn slowly led Ontario into recession. By 1990, when the Liberals called the next election, the economic optimism was over. The Liberals were sitting at $50 \%$ in the polls when they called the election, but their lead quickly dwindled. The early election, called after only three years of a four-to-five-year mandate, became an issue, and the voters were anxious about their poor economic prospects, the inability of the Liberals to do anything about the Canada-US free trade agreement, the rote campaign of the Liberals that lacked a clear agenda for the future and a lingering political scandal $(12,45-46$; Rachlis \& Wolfe, 1997:332; Cameron \& White, 2000:12-13). Having rejected both the Liberals and the Conservatives, the voters elected the NDP with a majority. Although the NDP had only $37 \%$ of the popular vote, it gained $57 \%$ of the seats in the legislature (Rachlis $\&$ Wolfe, 1997:331).

50 The robust list of policy achievements emanating from the accord may seem to belie Boix's sense that gridlock rather than policy decisions is likely to occur in coalition governments, due to internal fragmentation and polarization within cabinet (Boix, 1997: 494). The Liberal-NDP accord, however, was not a coalition government and the NDP - the junior partner - did not play a role in Cabinet. 
The NDP came to power in Ontario with many obstacles before it, many of them of the party's own making. The party operated from a mentality of "permanent opposition", with issues reduced to 'us versus them' dynamics that suited Question Period oppositional politics, but not the demands of government. Thus, they had never addressed the critical questions of "priority, sequencing, or means" faced by government (333-335). At the invitation of the party prior to the election, the critical issue of economic policy underwent a critique by economist academics, but the unexpected election call left the project in limbo (Walkom, 1994:52-57). In terms of internal organization, the elected members of the party also operated in isolation from the party apparatus and broader membership. This had two serious impacts on the ability of the party to govern. First, the party underwent an economic policy review prior to the 1990 election, but did not consult the membership, which remained isolated from policies it had no part in developing. Second, the review had little impact on the party's election platform (Rachlis \& Wolfe, 1997:334). Instead, the election platform was a cobbled together set of party policies created as a pre-leaders' debate tool during the election (360). Consequently, the new government's first legislative session lacked "strategic focus and internal consistency" (338).

It was, however, the government's first budget in spring 1991 that created a critical moment in credibility, putting it "on a collision course with the province's business community and began its downward slide in the opinion polls" (339). ${ }^{51}$ The NDP never regained this support. The budget was a supply-side, Keynesian budget that

51 Government popularity went from $60 \%$ in January 1991 to $36 \%$ in September 1991, the first anniversary of the election. The budget itself (in April 1991) dropped popularity 20\% (Tanguay, 1997:23). 
sought in its own words, to fight the recession, rather than the deficit, but it was not sufficiently Keynesian to make the difference in the economy it sought (McBride, 1996:78):

The [budget] was the worst of all worlds--a budget Keynesian enough to anger business but not stimulative enough to do much good... The ferocity of the reaction against the budget took the government by surprise. By 1991, it had become "accepted wisdom" in both business circles and the media that government debt was bad. The Rae government, however, did not understand how deeply this neo-conservative orthodoxy had seeped into society (Walkom, 1994:103).

The budget showed a government "lacking in experience, self-confidence, and, most important, a clear vision of an alternative economic strategy" (McBride, 1996:78).

The failed budget experience was important for two reasons: it increased the province's debt and expenditures substantially, and it began the government's reversal in election commitments (Woolstencroft, 1997b:368). ${ }^{52}$ The lack of consultation with the party apparatus on these-long-held NDP policies and their unilateral announcement reflected the "hypercentralization of power" within a small group of senior advisers to the Premier (Tanguay, 1997:25).

The reversal in fiscal direction was made clear in the government's 1993 announcement of a deficit reduction initiative. Along with public spending cuts and raising revenue through tax and non-tax measures, the government imposed a coercive Social Contract on public service labour unions that meant the opening of previously negotiated collective agreements and subsequently the loss of income and benefits (Walkom, 1994:130-134). In his remarks to the unions, Premier Bob Rae took a classic

52 Three major reversals concerned public automobile insurance, Sunday shopping and casino gambling. 
neo-liberal TINA ('there is no alternative') position by embracing deficit reduction and attacking the public sector:

Unless we reduce operating costs... we will no longer be able to afford the level of public investment Ontario needs in jobs, training and capital to meet the economic challenges of the 1990s... [I]f we don't do anything to get government costs under control now... many, many more public service jobs will be in jeopardy because our fiscal situation is not sustainable (Rachlis \& Wolfe, 1997:354-355).

The Ontario "social contract" ${ }^{53}$ of 1993 is an interesting contrast to the reaction of the Australian Labor Party, when in government, to declining revenue and rising deficits. This underlines the possibilities of policy choices beyond the neo-liberal response taken by Ontario. Australia underwent neo-liberal reform only after having negotiated a consensual accord with trade unions (Neilson, 1998:55). ${ }^{54}$ In contrast, in an interview just prior to the 1995 election call, Rae regretted only that he didn't cut public service spending sooner (Ottawa Citizen, 1995:A4).

Yet, the point must also be made that Ontario, as a province within a federalprovincial system, was dependent to some extent on an adversarial federal government also attempting to reduce its deficit. The federal government's fiscal policies capped on transfer funding under the Canada Assistance Program and froze transfer funding under the Canada Health and Services Transfer. Ontario was also, with or without its consent, a party to the federal government's tight monetary policy, in which the Bank of Canada kept interest rates high, which lowered inflation at the expense of employment.

53 The social contract was a restraint initiative that opened up collective agreements and rolled back wages in the broader public sector by $5 \%$ to find $\$ 2$ billion in expenditure savings. When the unions left social contract negotiations, the government enacted legislation to impose the restraints (Tanguay, 1997:26-27).

54 The government earlier rejected a proposal from the Canadian Union of Public Employees for a more "modest" social contract (McBride, 1996:79; Walkom, 1994:130-1). 
Different federal policies would have raised GDP, lowered unemployment and the deficit (Rachlis \& Wolfe, 1997:342-343). It would be difficult even for committed social democratic parties to continue with Keynesianism in a "small, open and regionally differentiated economy permeated by high levels of foreign direct investment" (McBride, 1996:70).

The Rae government managed to both alienate its supporters, by not keeping its promises and imposing a social contract, and its opponents, by taking a somewhat Keynesian stance in its first budget, from which public opinion never recovered. Both supporters and detractors found themselves resisting the government, sometimes on the same side for the same initiative, as labour unions and the Ontario Hospital Association did in response to the social contract. To McBride (1996), the failed NDP government and other NDP provincial governments represent "the exhaustion and failure of social democratic economic analysis and policy" (66). Its problems emanate from "a profound gap in the party's capacity to understand the new economic circumstances it faces... Lacking a theoretically cohesive account of contemporary capitalism the party, when in office, seems doomed to replicate the policy objectives of its political rivals" (69). This tendency to take up the status quo capitalist analysis and lack of forward-looking intellectual analysis subjugates the social democratic alternative, which cannot thrive politically without legitimation.

Part of the reason for the social democratic alternative's inability to thrive lies in the post-war success of Keynesianism, which reduced differences between political parties. But these parties, in their cautious and moderate stances, have sometimes not sought to differentiate themselves from the alternative either. In a critical time of 
epochal change from one economic paradigm to another (Robinson, 1996a:3), "renewed economic crisis has been more disruptive for social democracy than for ideologies with right-wing origins" (McBride, 1996:70).

It seems obvious that the NDP government did not establish hegemony in its four years in office. It is unlikely that, given their lack of readiness for office-no coherent team or comprehensive program (Williamson \& Haggard, 1994:578-584)and the early setback from its first budget, the government even attempted seriously to build the hegemonic bloc it required for a party that was elected with only $37 \%$ of the popular vote. This seems borne out by the party's campaign during the 1995 election, in which it seemed unprepared for the election that it called (MacDermid, 1997:83, 88, 93, 100). Its re-election campaign centred on the social contract and the leadership of Premier Rae, managing both to alienate party supporters and targetted supporters (Tanguay, 1997:27-28). The NDP became "trapped in an agenda and discourse shaped entirely by others" (McBride, 1996:73). Perversely, its experience made visible the crisis in social democracy.

In contrast to the NDP, the Progressive Conservatives were a government-inwaiting. Having lost three elections in a row in 1985, 1987 and 1990 under Frank Miller, who was a traditional Conservative, and Larry Grossman, a "Red Tory" (progressive on social issues), who could not unite the party, the Conservatives began to rebuild under its new leader, Mike Harris. As part of this "strategic planning exercise", it identified four deficits that were holding the party back: intellectual (no policy making capacity), financial (deeply in debt), strategic (no sense of direction) and organizational (a weak and divided base) (Blizzard, 1995:10; Woolstencroft, 
1997b:370-371; Cameron \& White, 2000:79). The party explicitly looked to business and other organizations for information and inspiration on how they strengthened their enterprises in competitive situations (Woolstencroft, 1997b:370). An important shift in party thinking strategically, and perhaps in response to the NDP's experience in government, was to think "not just in terms of winning the next election... but also about how it would govern once in office" (373; Cameron \& White, 2000:81).

In addition to the extensive leader's tours, meetings and fundraising that eliminated the party's other deficits, the party also addressed the intellectual deficit by designing from the grass-roots up a new mission a set of policies, which it then outlined in an election platform package called the Common Sense Revolution (CSR) (371-375). In contrast to traditional, Canadian-style brokerage politics that only demand vague promises and platforms during an election, the CSR was explicit in its policies and precise in what, how and when it would implement them. It also released the election platform a full year before the expected 1995 election (Blizzard, 1996:3, 45; Cameron \& White, 2000:15), "very much contrary not only to brokerage politics but commonly held political science ideas about election behaviour" (Woolstencroft, 1997a:40-41). The Conservatives emphasized the break from the past by dropping the name "Progressive Conservative" and reinventing themselves as "Tories." ${ }^{\text {"55 }}$ Although the moral authority aspects of conservatism would remain in their policies and in their actions once in government, the new "brand label" (with matching purple to replace traditional Conservative blue) spoke to voter dislike of the old label (Blizzard, 1995, 3,

\footnotetext{
55 The party name "Progressive Conservative" was tested in focus groups during the Ontario party's renewal process and was found to remind the public negatively of their dislike for then Prime Minister Brian Mulroney, so the Ontario party is now informally known by the traditional nickname for Conservative politicians, "Tories" (Woolstencroft, 1997b:376).
} 
45; Woolstencroft, 1997b:376). The new name also spoke to the desire for change: Polling showed that $50 \%$ of Ontarians believed the province was on the wrong track and seven out of 10 believed that major change was needed to turn it around (376). The Conservatives were able to "tap into voter anger and anxiety, and portray the opposition as part of the problem", according to Rachlis \& Wolfe (1997:357), who argue that this is "the same source of NDP strength in 1990"; if so, this underlines the ongoing organic crisis faced by Ontario citizens in the 1985 to 1995 period (Ehring \& Roberts, 1993:273).

At the beginning of the 1995 election campaign, the Liberals were high in the polls and it was widely believed they would form the next government (Blizzard, 1996:116). Instead, the third-place Conservatives slowly began to rise in the polls and, soon after the televised leaders' debate, assumed the lead (116). By election day, this translated into a majority victory for the Conservatives, a "modest" victory compared to earlier Conservative majorities, but still a victory (Woolstencroft, 1997b:385) ${ }^{56}$ It marked the third shift in government in three elections.

The Conservatives owed their success in the 1995 election to the reinvention of the party. They went into the election with a renewed party structure, revived membership, carefully selected and well-prepared candidates, a resonant party platform and a leader who had experienced and led the revival. In Williamson's (1994) terms, the new government had a strong political base, a demoralized opposition, a visionary

56 The Conservatives won a parliamentary majority with 82 of 130 seats, but had less than $50 \%$ of the popular vote (44.8\%) (Tanguay, 1997:22). 
leader, a coherent team and a comprehensive program-elements critical to market policy reform which can lead to a new hegemony (Williamson, 1994:563). ${ }^{57}$

They also owed a debt to Premier Ralph Klein of Alberta and his Treasurer Jim Dinning for advice on electoral and legislative content and strategy (Ibbitson, 1997:53; Long, 1995:11), as well as linkages to the US Republican Party on election approaches and strategy (Woolstencroft, 1997a:45). Extensive public opinion research and a large and efficient advertising buy enhanced the ability of the Conservatives to get their message out to Ontarians (this will be discussed in chapter 4).

The Conservatives also signalled through their abandonment of brokerage politics that they had not only broken away from the old Conservative party, but from the old politics as well. There would be no more balancing of societal interests, evolving consensuses or avoidance of ideological conflict; instead, the new government was willing to pit interests against each other, take ideological positions and reverse the consensus of the previous decade (939). In fact, 'consensus' appeared to be doubleedged for the Conservatives. A measure of consensus was needed to win elections, but it would not prevent the Conservatives from forming new strategic alliances when needed between elections.

Federally, core Conservative support was too low ever to gain power without relying on a "coalition of interests", an uphill battle, given that there was seldom the opportunity to enlarge the core vote through evidence of "wise governing" (Simpson, 1984:xi, 62) and there was a constant need to reinforce support. Provincially in postwar Ontario, Conservatives had no trouble getting elected, but this was by virtue of

57 It is interesting that Tom Long, campaign chair for the Conservatives, used Williamson's language when he described his party's "cohesive, coherent, comprehensive blueprint for change" (Long, 1995:7). 
appeals that went beyond partisan status to create a stable majority through brokerage politics tempered by the inclusive compromise politics of Keynesianism. Although Ontarians generally voted Liberal federally and Conservative provincially, there was no sense of a divide between what they wanted from a federal government and what they wanted from a provincial one.

The 1995 election was important both ideologically and politically. Ideologically, the election represented "a fundamental shift in the balance of power between the state on the one hand and the private sector and the individual citizen on the other", according to senior Conservative advisor, Tom Long (7). Politically, it redefined Conservatism and in so doing prevented the encroachment of the Reform Party in Ontario (Woolstencroft, 1997a:41). In moving to the right, Ontario Conservatives broke with the stable alliances and brokerage politics of the past to more strategic and short-term alliances (this will be discussed in the next chapter).

Thus the Harris Conservatives introduced a response to economic crisis that has been termed by Neilson (1989) as the pursuit of an active hegemony. Unlike the nonhegemonic restructuring response of New Zealand and Canada (and Britain-its election manifesto was not clear, although Thatcher's intentions were obvious), Harris pursued a new hegemony as a mandate rather than a goal (Neilson, 1989:51-53).

\section{Conclusion: The Transformation of the Political Economy}

In the latter part of the 20th century, a shift began to take place in the economic orthodoxy of Western industrialized nations from Keynesianism to a new paradigm that has gradually coalesced around the name "neo-liberalism" (N. Rose, 1996:53; Isin, 
1998:174). Neo-liberalism is an amalgam of moral conservatism and classic liberalism, and, in its current incarnation, often potent in its populist appeal. The shift to neoliberalism was a response to a crisis in capitalist accumulation precipitated by globalization of national economies and the realization that the economic crises of late capitalism were not responding to Keynesian economic theory. In addition to economic instability, "the old balance of forces that exercised hegemony was disintegrating" (Jesson et al, 1988:26). The consensus that had underpinned Western states faltered as new political responses to changing economic circumstances struggled for preeminence. Together the social and economic instability constituted an organic crisis of state and civil society.

The hallmarks of neo-liberalism are liberalization, privatization, restructuring and commercialization. The aim of neo-liberalism is to transform, but not eliminate, the state by allowing the market to lead the economy. The most common political strategies that support neo-liberalism are reducing deficits, cutting public expenditure and opening up markets to competition (such as free trade).

Attempts to establish a new neo-liberal hegemony have met with varied success. Hegemonic projects are highly contingent. They are historically situated and thus influenced by a full range of ideological, political, economic, social and cultural influences within their own national histories. Such projects are also constructed in struggle, not imposed by a group or class (Simon, 1982:63).

The account of Thatcherism in Great Britain demonstrates how the strong ideology of an intended hegemonic project (telegraphed in advance and pursued as an electoral mandate) is not sufficient on its own to ensure success of a hegemonic project. 
Great Britain's project was tempered by pragmatic politics, aided by historical conjuncture and resisted strongly by the political opposition (including governing party dissidents) and social movements. The result is an as-yet incomplete project that may gain strength with time, as much of the project has not been reversed after a change in government (this will be discussed in chapter 4). Under Neilson's (1998:51-53) theory, Thatcherism is a "non-hegemonic restructuring" response to a crisis.

The experience of New Zealand, on the other hand, illustrates how an unintended hegemonic project (not telegraphed but pursued as a goal) can, through political resoluteness, institutional structure and political culture, become an hegemonic project-Neilson's (1989:51-53) "active hegemonic" response to a crisis--but not a necessarily a durable one (Gamble, 1993:10), as it was not constructed organically. In Gramscian terms, the projects in Great Britain and New Zealand had not sufficiently constructed the conditions for a change in the balance of forces (Gramsci, 1971:180); that is, in McBride's (1992:20) terms, ideology was still visible.

In Canada, the response to the same global forces and national economic crisis as the other countries, was similar to that of Great Britain, but based on its own unique economic and political structure, history and culture. Canada demonstrated how an unintended hegemonic project could falter from lack of political commitment and a particular political culture that valued brokerage-style decision and policy making, but nonetheless moved gradually towards achieving its goal. ${ }^{58}$ The federal lack of success may have been due to the bifurcated federal-provincial system, which meant its success

58 In this regard, I differ from McBride (1992) and others who see the battle between Keynesianism and monetarism in Canada as having been won by the neo-liberals by the time the Conservatives came to power in 1984. If so, then the endgame has been long. In keeping with Gramsci, I see the winning of hegemony as a gradual process and would argue that in Canada, the process (including the struggle against it) continues. 
was not as evident as it would have been in other jurisdictions without strong provincial powers. Yet it is possible that the federal experience of 'incomplete' neo-liberalism can be considered more durable, since it transformed existing ideologies and yet has continuity with the past. It may also have provided a conditioning framework for later provincial reform. In terms of an 'intended' or 'unintended' hegemonic project, Ontario followed the path taken by New Zealand and Alberta, with an intended project that benefited from volatile political conditions and continues to move towards a new hegemony ${ }^{59}$ Similarly, Great Britain, New Zealand, Canada and Ontario took on market reform, but applied it differently and with varying success. For instance, privatization under neo-liberal governments was not pervasive in most OECD countries, but New Zealand was an exception with exceptionally high privatization, followed by Great Britain (Boix, 1997:476). ${ }^{60}$ Canada's privatization is judged to be only slightly more than the status quo and in Ontario, there was very little privatization in the government's first term (476).

The 'success' of the neo-liberal projects in these countries, whether hegemonic or non-hegemonic, also benefited from social and economic conditions that manifested themselves in electoral behaviour: partisan dealignment, class or group dealignment, voter apathy and voter volatility (Edgell \& Duke, 1991; Clarke et al, 1996).

\footnotetext{
59 Although Canada's project was strongly influenced by the United States intellectually and materially, the latter's 'project' does not fit the pattern described in this thesis. For instance, although the US has national social programs such as social assistance, it does not have the entrenched and (at the time) universal social programs that have proved to be obstacles to the implementation of neo-liberalism. It also has a different political system than the Westminster system used by the other jurisdictions mentioned in this thesis. In addition, conservatism, not to mention the religious Right, have always been strong in that country, unlike in Great Britain, New Zealand and Canada.

${ }_{60}$ The United States, also a member of OECD, was not included in Boix's research.
} 
There is no tried-and-true formula for how to implement neo-liberal reforms, although Williamson's "Manual for Technopols" comes close to achieving its purpose. Williamson provides many useful insights into the various elements that comprise a 'successful' neo-liberal market reform package, and many of these have been referred to in this chapter. Similarly, Kelsey's "Manual for Counter-technopols" cannot promise exits from neo-liberalism, although it offers points to consider for resisting neoliberalism that can help identify conditions that may promote a culture that supports market-driven reform (Kelsey, 1995:372-376). Williamson's taxonomy serves to point out that the tendencies cannot be seen as prescriptions because of the endless conjunctures that can mediate a country's situation at the point of entry of neo-liberal ideology and policies. This thesis argues that the point of entry itself, the conditions that exist and that it creates (the threat of crisis with no alternative) is a contested and highly volatile moment of hegemonic transition.

As a promotion of neo-liberalism that emanates from an elite Washington institution (the Institute for International Economics), Williamson's manual also serves as a reminder of the power behind neo-liberalism to restructure at will: "Neoliberal discourse is not just one discourse among many but aided by elites: It is so strong and so hard to combat only because it has on its side all of the forces of a world of relations of forces, a world that it contributes to making what it is" (Bourdieu, 1998:2).

The emphasis in this chapter has been on the "political and ideological conditions of crisis" under which reforming governments came to power (Hall 1988:124). This helps to clarify the nature of hegemonic projects and consensus. Throughout this chapter there has been an emphasis on the economic, both as structure 
and sphere of influence. This may seem to fall into the "trap" posed by Hall (1988:170) of "the old mechanical economism and belie[f] that if you can only get hold of the economy, you can move the rest of life." This is not intended either to privilege the economic falsely or to demonize it. The point must be made that it figured prominently in all accounts of the shift to neo-liberalism emanating from both the Left and the Right, and in many accounts was accorded the status of most significant condition in shaping the shift to neo-liberalism, in recognition that it is based in capital's need for accumulation strategies that increase profit and profit-making capacity and will continue to do so: "Ultimately, the success or failure of such a hegemonic project is dependent on the capacity of the accumulation strategy to continue to provide economic growth" (Jessop et al, 1988, 180). Obviously, it is in the best interests of capitalism to maintain this narrow framing of neo-liberalism as economic-to the neo-liberals, success is measured in GDP growth, after all (Cameron, 1990:437)-and we have seen in this chapter the lengths to which the elites go to pre-condition the environment to support neo-liberalism. But neither can the economic imperative of neo-liberalism, with its economic roots in individualism, be denied.

The separation of economic and social spheres encountered in neo-liberal practice is related also to the liberal thread in this philosophy and runs counter to Gramsci's (1971:263) emphasis on the state as including both civil and political society. Yet, literally on another level, that of superstructure, the Right is cognizant that a hegemonic project requires both "material infrastructures... and intellectual superstructure" in order to win hegemony (George, 1997:263). Unlike neo-liberal practice, which prioritizes the economic sphere and expects social and moral order to 
follow, neo-liberalism also works dialectically on both levels to construct conditions for hegemonic success-a nuanced and ongoing ideological effect that emanates from "shifts in everyday practices and routines with major ideological implications" (Jessop et al, 1990:94).

This chapter, however, has also emphasized how New Right thinking was predisposed to respond in economic terms to a 'crisis' that its adherents determined existed. In reference to neo-liberal privatization strategies, Boix (1997:476) points out that economic crisis in the 1980s provided the wedge to begin chipping away at the welfare state, but privatization strategies taken in response are predicated less on economic performance (although that was a necessary element) than on the partisan composition of the government and the internal structure of the Cabinet: "[T]he privatization movement was mainly driven by the political actors in power at the time, constrained by the institutional settings in which they operated." This implies that ideological choices exist and reflect a combination of agency (actors in their social settings) and structure (institutional settings), which is borne out by the accounts in this chapter. The choices made by governments and government-in-waiting were different, but they demonstrate a clear ideological framework at play; in the "permanent trade-off between stability and change, and between consensus and responsiveness", most Rightleaning governments choose change and responsiveness, while most Left-leaning governments choose stability and consensus (496). This finding is emphasized by the New Zealand example which began under a Left government with public sector restructuring, drawing criticism from the Right (Williamson, 1995:580), and continued its reforms under a Right government, which focused on the deficit (Schwartz, 1997:1). 
The emphasis on dissecting the components of neo-liberalism and how they are applied in specific political situations helps illustrate the continued lack of consensus within the restructured state. To the extent that electoral formulations are able to mirror the public's views (and we have seen how electoral systems have a differentiated capacity to do this), there are openings within neo-liberalism for contestation. Beyond electoral formulations, the response of social movements to neo-liberalism demonstrates that oppositional space exists at both national and international levels and is widening as it becomes clear that "neo-liberal regimes have resulted in extensive market freedom, but little economic or social stability" (Albo, 1995:107-108).

With that in mind, in chapter 4 this thesis will examine the social aspects of neo-liberalism in acknowledgment of the changes to the public sphere and conceptions of democracy as well as the public discontent that has characterized the last two decades. This will require a tugging away from the unintended economism in this chapter and back towards social relations. This acknowledges that neo-liberalism creates a social and democratic deficit while solving the 'problem' of the economic deficit. 'Success' cannot be measured only by the extent of economic-corporate domination, but also in the extent of suppression of democracy (Robinson 1996a:338). In keeping with Gramsci, neo-liberalism must also be examined on the terrain of social relations in civil society, as it is "the sphere of class struggles and of popular democratic struggles" (Simon, 1982:26) and the location of "the processes of social reproduction and social change" (Ransome, 1992:7). The thesis thus also examines the contestation that emerges when "the state fails to maintain a balance between ensuring the conditions 
for the accumulation of capital and protecting the collective well-being of citizens" (Harder, 1996:39), and the government's use of legitimating resources to counter this. This chapter has also introduced the use of communication in shifting neoliberalism from the periphery of modern political thinking to become a major restructuring force. As has been argued in this chapter, the pursuit of hegemony is historically situated and highly contingent. While there are many commonalities, each manifestation of neo-liberalism is particularized. The common thread in these accounts that is central to this thesis is communication and the role it plays in the construction of neo-liberalism.

Communication is a vital, determining element in the successful construction of the neo-liberal project and concomitant new political realities. Hegemony must be constructed and won in both the state and civil society. Communication is both persuasive ideological force and strategic political practice, and it is used by the state to gain consensus in what can be a coercive process. A neo-liberal project employs communications processes intentionally and selectively to communicate policies persuasively that privilege political elites and their ideological objectives at the expense of democratic communication and a healthy public sphere. In addition to its impact on the public sphere, the communication of neo-liberalism also contributes to the reconstruction of the state. Modern politics also requires the collaboration of both paid (public relations) and unpaid (traditional 'democratic') media to construct a neo-liberal hegemony. The next chapter will thus focus on the political communication of neoliberalism in the context of building an 'historic bloc' in Ontario. 


\section{CHAPTER 3: POLITICAL COMMUNICATION: LEGITIMATION AND CONSENT FOR THE NEO-LIBERAL PROJECT}

\section{Introduction: Communication as Legitimation}

The previous chapter demonstrated the development of a paradigm associated with the New Right under conditions of economic crisis as a reaction to the social and economic inclusion of the post-war Keynesian compromise. It also demonstrated the impact of neo-liberalism in establishing itself as the mainstream political and economic paradigm in Western industrialized countries. It also briefly examined the growth of elite institutions both nationally and internationally that help to strengthen neo-liberalism and extend it to countries of the majority world (Third World). By summarizing the experience of neo-liberalism in different jurisdictions, this thesis has sought to demonstrate the specific conditions under which neo-liberal projects develop, as well as their ideological, social and economic commonalities. A further area of examination has been the ongoing public resistance to the new paradigm.

This thesis contends that these neo-liberal projects are hegemonic in nature, as they seek to establish a new paradigm, and have varying degrees of success. In this, the Gramscian theory of hegemony offers possibilities for exploring the constitutive elements of such projects and their intersections, including civil society, the state, political society and the superstructural elements that play a legitimating role in winning public consent for these projects. There are instances when public consent is either not won or is viewed to be too difficult to achieve and examples of this in the Ontario context will be examined in chapter 5 . This chapter will concentrate on the legitimation 
and consent for neo-liberal projects, positioning communication as playing a central role. It will look at the components of political communication—government, media and public sphere-and how their changing roles under neo-liberalism contribute to both short-term and more durable legitimation.

As we have seen from an examination of Gramsci's theory of hegemony and from many of his key concepts, consent comprises a duality, including both consensual and coercive elements. The coercive form of consent has been referred to as "manufacturing consent" (Herman \& Chomsky, 1988)-the systemic and systematic government and media 'propaganda' in the guise of objectivity and other filtering that appears so natural that the public's apparent acceptance, or consent, is not problematic. This is a stark rendering of the coercive process to gain consent put forward most notably by Herman and Chomsky (1988), but it serves to demonstrate how coercion and consent work together. Other like-minded theorists nonetheless take care to explain that true propaganda is isolated and manifested at specific historic times such as during wartime and not in regular government-media-public communication (Blumler \& Gurevitch, 1991; Perloff 1998).

State coercion is usually invisible, but times of crisis or paradigm change create conflict and competition until the new regime is able to legitimate itself (McBride, 1992:12). Much of legitimation under Keynesianism took the form of concessions and benefits that came to characterize the Keynesian consensus; this and other paradigms thus have policy consequences, which the new regime must justify, or for which it must gain consent (McBride, 1992:13, 18). If the policies are a significant change from those under the old paradigm with consequences that will radically change society, the task of 
legitimation becomes more important and more challenging. State actions to ensure legitimation increase and may become more visible and aggressive.

Legitimation is a complex concept that examines "ways in which meaning may be mobilized in the social world" (Thompson, 1990:61). Gramsci provides the basic concept of the ability of a social group through its intellectual and moral leadership to organize and maintain consent. Quoting Weber, Thompson (1990) provides specifics on how this can be accomplished. The claims to legitimacy implied in dominant social relations are based on rational, traditional or charismatic grounds (61). They can be expressed typically by strategies such as rationalization (a chain of reasoning developed to defend or justify the claim); universalization (in which the interests of some are presented as the interests of all); and narrativization (where the past is presented as cherished tradition) (61-62). ${ }^{1}$ These strategies allow the persuader to create meanings which resonate with the receivers of the messages. Thompson notes that these and other strategies are not intrinsically ideological, but that they have the capacity to be so depending on "whether the symbolic form [the message] so constructed is serving, in these circumstances, to sustain or subvert, to establish or undermine, relations of dominance" (61). Thompson (like Weber and Gramsci) thus goes beyond notions of coercion to understand more precisely how dominant groups gain and maintain their hegemonic position. McBride (1992:21) emphasizes how these and other strategies for consent operate at both the level of ideas and on a material basis, using as an example the legitimation strategy identified by Thompson of how a ruling social group combines its interests with that of others and presents it universally. He also points out how, once

1 Thompson also details other "modes of operation of ideology," but the legitimation mode is of central interest here. 
established, a hegemonic project can go beyond symbolic strategies and utilize the many instruments of the state to maintain its position of dominance through persuasion. These include budget and throne speeches, royal commissions and task-forces, public consultations, advertising and changes to program (106-116).

The use of strategies of legitimation and consent by neo-liberal governments represents a new and virtually unexplored form of political communication. Political communication is a formal area of communications research that offers a point of departure for setting an initial framework for an examination of Ontario's experience with the neo-liberal project. A traditional understanding of political communication is "the process by which a nation's leadership, media, and citizenry exchange and confer meaning upon messages that relate to the conduct of public policy" (Perloff, 1998:8). While this correctly identifies the main actors, it does not adequately account for the material and symbolic conditions in which policy action evolves, particularly the contestation and negotiating power involved in privileging issues and bringing them to public attention (Deacon \& Golding, 1994:17-8).

Concern with the limits of the term 'political communication' leads this thesis to attempt to broaden and deepen the traditional concept. Consequently, this thesis hopes to demonstrate the value of refocusing political communication to hegemonic communication in order to incorporate Gramsci's theory of hegemony. Instead of the traditional short-term and narrow focus of political communication on elections, electoral mandates or policy cycles, this thesis extends the concept to incorporate longterm, project-wide and paradigm-changing implications. It will move beyond media practice to include communications institutions and processes and, ultimately in the 
conclusion of this thesis, lead to a discussion on communicative democracy, instead of the less inclusive category of media democracy. Moving from political communication to hegemonic communication is useful in thinking about hegemonic projects as it centres the ruling social group's interests within relations of power without either neglecting (as traditional political communications does) or assuming ideological inevitability or exclusivity. It also keeps in mind the goal of such a project, which is hegemonic (long-term and durable) rather than electoral success (as in a short-term political mandate). Although examining each of the three spheres of political communication separately, this thesis will also place them within the context of constitutive parts of a social totality, played out in Gramsci's civil and political society. Importantly, hegemonic communication carries with it the struggle and agency integral to Gramsci's approach and therefore includes counter-hegemony with its implication of transformation. This reflects Gramsci's openness to ideological and hegemonic struggle instead of a 'crude' determinism. It also speaks to the hegemonic role for media in legitimating neo-liberal projects: the usual means to secure consent, such as corporatist structures, party and parliament, are no longer effective, so the media are "increasingly relied on to provide the consent for policies that was obtainable from no other source" (Gamble, 1993:204). It is in their hegemonic role that the media are caught up in the ideological offensives (Golding, 1991), beginning with the manufacturing or emphasizing of crisis (Hall et al, 1978; Hall 1988), that mark the form of political communication used by hegemonic, neo-liberal governments in "structuring understanding and winning the popular consent that is at the heart of hegemony" (Knight, 1998:96). 
The term 'hegemonic communication' is put forward tentatively, but nonetheless with an underlying strong belief that political communication does not have the explanatory power to illuminate ideologically charged conjunctures and crises that lead to the societal transformation of a new paradigm. For instance, Deacon and Golding (1994:10) point out that traditional political communication is limited by an obsession with elections, close (partisan) framing of issues and a national focus. Clearly, this thesis intends to move beyond these traditional parameters.

For the sake of clarity, however, since the literature on political communications uses the term 'political communication,' this thesis will continue to use it as well, but the context will be sufficiently clear to establish how the term is being used.

\section{The State: Restructuring and Governmentality under Neo-Liberalism}

The corporatist tendency that underpinned the Keynesian post-war compromise was, as the term 'compromise' implies, built on a consensual agreement between capital and labour which would lead to a negotiated economic settlement (Oliver, 1989:37). The implication was that this consensus would in itself foster national unity and common purpose-in effect, it would be self-legitimating. Neo-liberal politics takes a different approach. As neo-liberalism restructures the state, its goal is not a day-to-day negotiation with labour and other social forces, but the pursuit of "a more lasting consensus around an apparently apolitical and minimalist notion of the state" (Harder, 1996:59). Many of these hegemonic views that comprised the "common sense currency of everyday life"- the free elections, free markets, free press, free flow of information (Mosco, 1996:243)-are being challenged or de-privileged as the state itself is 
restructured. (As is not unusual, alternative and marginalized interests such as UNESCO's MacBride Commission took up these issues and positions long before the mainstream of modern society felt their impact.)

Jessop et al (1988:176) identify three trends in restructuring the state that emanate from Great Britain's experience: neo-liberalism weakens the state, increases the appointive state and centralizes power. These may seem to be contradictory or counter-intuitive - a weakened state is unlikely to be a centralized or strong state- but Jessop et al's trends speak to a central dichotomy in neo-liberal restructuring and state policy. Neo-liberalism does not abandon government; instead

it maintains the view that failure of government to achieve its objectives is to be overcome by inventing new strategies of government that will succeed.... They seek techniques of government that create a distance between the decisions of formal political institutions and other social actors, conceive of these actors in new ways as subjects of responsibility, autonomy and choice, and seek to act upon them through shaping and utilizing their freedom (Rose, 1996:53-54).

Neo-liberalism has problematized the state, questioning both its form and its limits (Held, 1986:6). It has shifted focus to rationalization and techniques of government that privilege extra-governmental expertise and non-governmental sites of power, including renewed power of the citizen as a client or customer (Isin, 1998:174). The result is "governance without government"- there may be fewer government institutions, but there are more government practices (174). Isin suggests that examination of neoliberal governments in Britain, US, Europe and Canada show they require more legislation, regulation and state resources than corporatist governments. ${ }^{2}$

2 The claim that neo-liberal governments require more state intervention is intriguing, but would be an extensive and hard-to-prove project. An attempt to interrogate this claim in a limited way was carried out through an examination of the first sessions of the legislature in Ontario for the current Ontario neoliberal government and the social democratic government preceding it. The findings are discussed later in this chapter. 
The 'appointive state' is a way of referring to institutions that have been created to take over privatized government operations. These parastatal and non-government institutions range in size, constitution, importance and mandate (Deacon \& Monk, 2000). The institutions themselves, created through arbitrary state authority, are sites of symbolic struggle between consent and coercion. Unlike their previous state incarnations, they provide little or no accountability to the public, represent an extension of market policy into the state (Sears, 1999:104) and demonstrate how private enterprise can be used as a model for government (Easton, 1989a:115).

Even when not off-loaded to the private sector, state restructuring can have a serious impact on remaining state activities and services. Armstrong (2001) explains how cutbacks and downsizing have a ripple effect on health care services in Ontario under what she calls "cascading privatization"-a steady weakening over time (Armstrong in Browne, 2001:16). It also emphasizes that restructuring such as privatization is not "a one-off event, or even a number of isolated interests, but a process" (6). Other downloading shifts state activity and power to municipal levels of government, such as the overhaul of Ontario's property and education tax systems under the 'megaweek' announcements of 1997 (to be discussed in chapters 4 and 5).

These patterns of privatization and other restructuring are not new in Canadian or Ontario politics. Royal commissions, notably the Macdonald commission on the economy, have "mobilized business-technocratic alliances behind new paradigms that in their breadth and detail amounted to fundamental reformulations of the received policy orthodoxy" (Bradford, 1999:48). This is also an example of Canada's politics by stealth (49), a "virtual displacement of policy innovation from the party system" to 
"arenas constitutionally isolated from electoral politics" (Clarke et al, 1996:17, 20). What is new is their breadth and their implicit rejection of the accepted modes of gaining consensus, such as electoral competition, corporatist bargaining and intergovernmental negotiation (Bradford, 1999:49).

International agreements (such as NAFTA) and the institutions that support them (such as the WTO) are also under scrutiny for what has been called the "new constitutionalism"--the legal and constitutional practices that create rights for corporations and remove them from citizen accountability (Parkland, 2000; Gill in Panitch \& Miliband, 1992:14). Dobbin (1998:92-3), Kelsey (1999:246) and Clarkson $(2002: 1,6)$ point out that this is accomplished without changes to national constitutions; it jeopardizes national sovereignty and creates a dual economy, one domestic with citizen input and the other international that is not accountable to state citizens (Dobbin, 1997:93).

While neo-liberal policies and projects are partially predicated on the idea of huge government and its apparatuses that must be brought under control, the impulse to restructure may have practical and ideological limits. Practically, for neo-liberals, a strong and centralized state—what Golding (1991:513) calls a "centripetal" state-is necessary for a number of reasons: a certain degree of state support and infrastructure is needed to discipline labour (by lowering wages, restraining inflation and reducing deficits), to compete and negotiate internationally (for access to American markets and export of resources) and to defend the system (by ideological, political and military means) (Langille, 1987:71, 77-78). In this regard, the World Bank has repositioned itself in terms of its endorsement of market-oriented policy reform abroad and 
acknowledges the need of some state infrastructure to manage and support the market (Kelsey, 1999:97-9). Gamble (1993:41-3) raises the point that the state may not only be in the business of rolling back its operations, but may at some point may need in a limited way to roll it forward. There is the risk of public resistance if the public and the political opposition become aware of and mobilize against their exclusion from input into these processes.

Ideologically, centralization of information and decision processes within the state apparatus are actually deepening state forms (Ratner, 1993:236), in effect 'embedding' communications processes into the system. In Ontario, Cabinet Officewhich plays the coordinating role taken on federally by the Privy Council Officerenamed the coordinating committee of cabinet to include its new communications responsibilities. The new Policy, Priorities and Communications Board requires a communication plan to accompany all policy proposals. The plan must have messages related to the policies in the Common Sense Revolution and are often accompanied by public opinion research findings on key publics that support the government (Fletcher, 2003). ${ }^{3}$ This is a reflection of the key role communication plays in government operations, linking it directly to legitimation by targeting audiences to whom the policy can be sold. ${ }^{4}$

Thus, "the nature of state intervention has changed, but the role of the state has not necessarily been diminished"' (Panitch \& Miliband, 1992:12). It is not so much a

\footnotetext{
3 Public opinion research received under the Freedom of Information Act of Ontario confirms the government's segmentation of different publics by sector, union status, support for the government and by region in addition to more traditional targeting by gender, age, occupation and income.

${ }_{4}$ This centralization of government communication decision making also took place in Great Britain under Thatcher and in New Zealand during its reforms (Ingham, 1991; Bruce, 1992; Atkinson, 1994a; Palmer, 2002).
} 
case of less or more government, but a fundamental rethinking (King, 1987:191, 195) within a "dialectic of integration-disintegration" (Gill, 1992:158). Changing the role of government has not limited and may have increased state power, moving towards both a free economy and a strong state (Gamble, 1993:35, 39). In this way, the state remains the primary source of its own legitimacy.

\section{The State: Government Information and Communication Management}

Golding (1994) draws attention to the growth in the "public relations state," or the realm of government information management (Blumler calls it "the modern publicity process" (1990:101), contending that the centripetal state is an information machine of increasing power, which is a threat to the free flow of information:

Where the institutions of public information are expressly intended to act as a check and balance on the undue concentration of power in the state, then the growth of that state as itself an information machine of formidable power is bound to pose a threat to the free and diverse distribution of information (Golding, 1994:13).

Golding's concern here is to go beyond the often narrow focus of communications research to examine the information environment as a whole. He notes that growth in the public relations state takes place concurrently with the decline of the public sector and increasingly unequal access to information through privatized communications systems (1994:13).

Keane (1991:94-95) in The Media and Democracy contends that it is the state that hinders the flow of information and opinion by its use of time-honoured state powers and the new techniques of official information management that he labels "political censorship," furthered by the spread of corporatism within the bureaucracy 
and unaccountable supra-government institutions. Keane thus rightly draws attention to a problem in the analysis of forms of neo-liberalism: the separation of trends that may be symptomatic of neo-liberalism and its policies from those which can be attributed more directly to neo-liberalism itself. This is not an easy problem to resolve, but there are areas where the evidence is clearer than others. Keane suggests different spheres in which he believes democracy has become obstructed through the political censorship of government information management, several of which have relevance to policies and actions taken specifically and identifiably by neo-liberal governments, including Ontario. They are: access to information; and public relations/marketing and advertising. ${ }^{5}$ To these can be added election and funding management; public input and legislative business and government communications management. Although this is a discussion that is critical to understanding how the public sphere can be changed under neo-liberal governments, these areas of government information management must be situated within changes in the practices of rule.

Access to information laws are being undermined by the restructuring of the state and the relocation of authority to different types of institutions (Roberts, 2001:244). Where once it was relatively straight-forward to determine which institutions should be subject to such laws, there are now many sites of governmentrelated activity, including crown corporations, quasi-governmental organizations, contractors and the private sector. When public functions are transferred to the private sector, statutes such as the Environmental Bill of Rights, Freedom of Information and

\footnotetext{
5 In total, Keane identifies five areas as follows: emergency powers (secrecy and access to information); armed secrecy (for national security); lying (government public relations); state advertising; and corporatism (elitism within government), pp. 95-109.
} 
Protection of Privacy Act, the Ombudsman Act and accountability mechanisms such as the provincial auditor do not apply to them (Winfield \& Jenish, 1998:140). As Atkinson (1989:101) notes, privatization increases private control of information that was formerly considered public and public sector downsizing can mean that some information is now longer being collected, either by government or privatized institutions.

In Ontario, the Freedom of Information and Privacy Act (FOIPPA) was amended in 1995 under the Conservative government. A study by Roberts (1999:422) concludes that public-sector restructuring undermined Ontarians' right of access to government information. A restrictive fee schedule, intended as a cost-recovery exercise, instead discouraged potential users and led to a dramatic reduction in FOIPPA requests ( $35 \%$ over four years), noticed particularly in the decline of requests for personal information (down 47\%). Roberts (199:429) notes that businesses seem the least affected by the fee hikes. The Ontario government also amended the FOIPPA in the Labour Relations Act of 1995, prior to the strike by Ontario public employees so that all records related to collective bargaining are now exempt from the law. ${ }^{6}$

Public relations, marketing and advertising have become an important aspect of government information and communication management. Professionalization of government communications and the higher profile that goes along with it has meant an increase in the number of communications workers, as well as workers with different kinds of communications-related experience, a result of movement back and forth

\footnotetext{
6 As I learned when requesting information under the Act, this is interpreted broadly. For instance, I was unable to obtain the government's "Strike Response Communication Guide" related to the public sector strike of 1996, even though it had already been leaked to the union and was to all intents and purposes a public document. Neither was I able to obtain costs related to the government advertising during the strike.
} 
between the public and private sectors (Atkinson, 1989; Savoie, 1994; MacDermid, 1997:79). Public relations, marketing and other "mass persuasion" experts and advisors form the "new elites," replacing "old elites that used to represent real communities of interest, and those public bureaucracies originally built as bulwarks of the poor and weak against the rich and powerful" (Atkinson, 1989:107).

Commercial marketing is "a social and managerial process," a "combination of activities by businesses to promote awareness of their products" (CSU, 2003:1). Within marketing, social marketing is "the use of marketing to influence social behaviour or bring about social change using ... commercial advertising" (SMI, 2003:1). A example of social marketing, which is prevalent in government, is an anti-smoking campaign. Another form of marketing is political marketing, which is the use of marketing for political activity. Within commercial marketing, there are many strategies: advertising, personal selling, sponsorships, public relations. In government, unlike in commercial marketing, advertising is intended to provide information about programs and services offered by government for its citizens. Government advertising campaigns, however, tend to leak beyond program information and into image-making and promotion, that is, legitimation for the purpose of gaining public consent, reflecting the ongoing tension between image and substance in the realm of politics (Palmer, 2002). For instance, increased frequency of government advertising can give a government a high profile and recognition for its policies, thus blurring the difference between government advertising (as information which promotes substance) and marketing (as communication which promotes image). A recent example is the Ontario government's householder program (see footnote 16), the frequency of which in Spring 2003 took on 
the aura of pre-election advertising even though householder content was strictly informational.

This new trend of marketing government activities (as opposed to government advertising) extends to marketing the state itself. This is evident in Great Britain's "Cool Britannia" promotions in the 1990s, Canada's embedding of state promotion in the Canada Information Office (J. Rose, 2000:101) and the City of Ottawa's recent selfbranding exercise (Mosco \& Mazepa, 2001). The key question that binds together all forms of these promotional efforts is "can the public sphere be shaped in the interests of the powerful by the pervasive presence of professional communication?" (Pieszka \& Schlesinger, 2002:200) A look at the marketing and communications efforts of the Ontario Progressive Conservatives, both before they came to power and in the 19951997 period, demonstrates the benefits of professional communication to becoming a hegemonic force.

In Ontario, the Progressive Conservative Party used advertising to promote its party platform before it came to government. In 1994, a year before the provincial election, the party spent $\$ 1$ million on a political marketing campaign that included a news conference by satellite, extensive advertising, a 1-800 number, a province-wide bus tour, wide distribution of the platform document and extensive briefings of media and the business and financial sector (Woolstencroft, 1997b:378). Although at the time there were many views about this unusual pre-election strategy, some party insiders felt it was important to make the point that the Conservatives were "committed to their proposals and were not just interested in winning the election" (379). 
For the 1995 election, the Conservative advertising strategy matched the overall campaign strategy (Drummond \& MacDermid, 1997:210). The strategy was disciplined and focused, with simple messages repeated over time. Echoing tactics used by the US Republicans (Fletcher, 2003:1-2), the campaign was heavily researched through polling and built around 'hot-button' issues that resonated particularly with middle and skilled working-class Ontarians (Woolstencroft, 1997a:42): “The... Conservative campaign... managed not only to pick the issues that were most disturbing the electorate but also to sell these in a way that their solutions were credible and that they could be trusted to carry them out" (Drummond \& MacDermid, 1997:210). The media 'buy' to place political advertising was singled out by a Conservative party advisor as critical to the campaign's success (209). The buy was weighted to television and saturation of its largest audiences, in keeping with the Conservatives' belief in the importance of television and its ability to reach audiences "unfiltered" by journalists and media processes (MacDermid, 1997:95).

Election and funding management changed dramatically under the Conservative government when it made substantial changes to these areas before the 1999 election. Their changes to the Election Finances Act have significantly raised the contribution limits (from $\$ 14,000$ to $\$ 25,000$ ); allowed the parties to spend more on central campaigns; and redefined election expenses to exclude polling and research costs and leader's tour expenses (MacDermid, 2000:1). Election financial statements show the Conservatives spent between $\$ 1.5$ and $\$ 17$ million (an Ontario record) on getting reelected, up from $\$ 2.6$ million in 1995 . This does not include contentious pre-election advertising, on which they spent $\$ 3.4$ million (2001:18). 
There are also little-known or understood aspects to the changes to election finances that benefit political parties that receive large donations and have benefits for the donors as well. For instance, although the limit that a contributor can give in any one year is $\$ 4,000$, additional contributions to the same limit can be made in the same year during a campaign period. This allows, for instance, additional contributions to be made for each by-election that is called within that year. MacDermid's (1999:9) research shows there were 14 such contribution opportunities in the period 1995-1997. MacDermid's study looked at just five of the 14 contribution opportunities in this period and found that 735 businesses donated the $\$ 4,000$ limit, compared to 58 individuals. Given that the Conservatives have always exceeded the fundraising ability of the other provincial parties and that the party is favoured in business donations (11), it follows that the Conservatives were the main beneficiaries of these opportunities. In total, the Conservatives received $\$ 4.67$ million in corporate donations from the byelections in the 1995-1997 period, while the Liberals received \$295,000 and the NDP did not receive any corporate donations (49).

Contributions to the Conservative Party not only surpass the other two major parties, but its list of donors includes wealthy individuals with connections to corporations that also contribute to the Conservatives. One-third of the top 30 corporate contributors, each donating between $\$ 27,000$ and $\$ 36,000$, are from the financial sector (27-28). The development industry, mining, food and drink sector, retail and road construction together are heavily represented on that list (29). MacDermid points out clearly that no policy change cannot in any way be attributed to a political contribution, although "in some cases... there were specific policy changes that were beneficial to a 
donor or a corporations to which that individual is related" (23). The list of contributors has "a number of coincidences or correlations that point to a pattern," and "there is still a problem of perception [of influence that can be bought] when such coincidences begin to accumulate" (23).

MacDermid (2000:3) says the figures show the "yawning gap between the financial health of the Progressive Conservative party, flush with contributions from wealthy individual and corporate supporters and the opposition..., deeply in debt. This can never be a good thing for democracy." The finance changes in the Act mark a return to high-stakes elections that only the wealthy can afford, much like the current system in the United States. ${ }^{8}$

Other revisions to election laws included changing the duration of election campaigns to 28 from 37 days. The time-frame allowed for advertising remains at three weeks; this may mean only a week of the campaign without advertising if it is flanked by pre-campaign advertising on one side and the campaign advertising itself on the other (MacDermid. 2000; 2003) in what has been termed the "extended campaign" (Fletcher, 2003:2). Not only does this commercialize most of the campaign period, but there is evidence that the length of election campaigns can have an impact on campaign outcomes. Stevenson and Vavreck (2000:233) show that short campaigns increase voter disengagement and cynicism, while longer campaigns give voters a chance to be

\footnotetext{
7 Large political donations have added incentive: they reap large tax credits for the donors. While individual donors get $75 \%$ of their donations back in the form of tax reductions, corporate contributions are $100 \%$ deductible and any unused credit can be brought forward to future tax years (Drummond $\&$ MacDermid, 1997:195; MacDermid, 1999:20).

8 In the US, election reform in 1974 led to large numbers of Political Action Committees to raise funds for election campaigns (Ginsberg 1986:160). As an example of their importance, PACs in the electronic and communications industries alone donated more than $\$ 9$ million to the 1994 US Congressional elections (Kennedy, 1996:14).
} 
exposed to and assess economic policy positions. ${ }^{9}$ Further, right-wing parties in government seem to have an advantage: "The left seems to be hurt by a bad economy, whether measured by inflation or unemployment, while the right seems actually to gain from higher unemployment, regardless of campaign length" (233).

The character of an election is changed in two important ways by the infusion of money. First, the choice by parties to spend election campaign money on television and other high-priced items is also a choice not to spend money on fostering authentic political discussion and dialogue or information on programs. In addition, when resources are scarce, "mass marketing also displaces other kinds of action, although it is not invariably the most effective response to social problems" (Atkinson, 1989:102). One-way, direct media such as television are just that—uni-directional—and do not contribute either to the broad politics or the enhanced civil society envisaged by Gramsci. Second, when campaigns are shaped by expensive advertising, it becomes easier to think of politics and political campaigns as a product, a commodity to be marketed and sold in the interest and to the advantage of the seller. As such, the Ontario election campaign of 1995 , with its massive saturation advertising, emphasizes a relationship between government and citizens as one between vendor and consumer. Media reports in early 2003 suggest that the expected Ontario provincial election was in its pre-campaign mode, with the government spending $\$ 5$ million on television advertising by May (Campbell, 2003:A9), and the Liberal opposition, having learned

9 Campaign length in Great Britain currently stands at three to four weeks, while the United States has an official campaign of two months (Semetko et al, 1991:11). Canada's campaign length has declined from almost eight weeks in the 1980 s to its current length of five weeks. 
the value of pre-election positioning, is advertising on television as well (Brennan \& Mallan, 2003:A7).

Legislative business and the way it is conducted has also been reshaped by the Conservatives. It has been widely claimed that neo-liberal governments require more legislation and regulation than non-neo-liberal governments (Isin, 1998:186). ${ }^{10}$

Since 1995, however, the government has used a different type of bill, called an 'omnibus' bill—a rarely used bill that "seeks to amend, repeal or enact several Acts, and is characterized by the fact that it has a number of related but separate parts" (Marleau \& Montpetit, 2000:615) ${ }^{11}$-more frequently than any other Ontario government. Legislation by omnibus bill is a strategy that attempts to avoid coordinated public and partisan opposition response to individual controversial elements within the bill (Drummond \& MacDermid 1997:256). The first omnibus bill, called the Savings and Restructuring Act (Bill 26) in 1996, was the "foundation of [the government's] cost-cutting, pro-business strategy, while the opposition parties were concerned that it was bringing major social change to Ontario and expanding executive power without proper debate" (256). It was introduced into the House at the same time as the government's first economic statement and several positive announcements, marking the first of many times that the government would concentrate major

${ }^{10}$ In his book on the new government, Ibbitson (1997) calls the government's first legislative session "no ordinary session... It was possibly the busiest sitting in the history of the province" (152). This is a difficult claim to prove or disprove in Ontario, given the state of record-keeping in the Ontario legislature. While my research indicates that the new government in 1995 introduced relatively the same number of bills in its first session as the previous government, this does not accord differential weight by type of bill (i.e. private members' bills vs other public bills), breadth of bill (i.e. omnibus bills) and the possible reach of their impacts. Record-keeping is further complicated by the two kinds of legislative committee, standing (ongoing) and select (ad hoc).

11 This being said, primary research shows that the government created five omnibus bills in its first mandate compared to two omnibus bills by the previous government. The Ontario legislature only records procedural objections to bills; until 1994, no procedural objection was recorded on the subject of omnibus bills, but that does not mean they were (or were not) used over the years. 
legislative and policy initiatives into a short period of time. Bill 26 itself was 2,000 pages long, amended dozens of pieces of legislation and gave the government "unprecedented powers" in multiple sectors, including health, education, parks and libraries (Mallan, 2003:H1). Despite this strategy, Bill 26 sparked strong reaction from the partisan opposition as well as national media coverage (Drummond \& MacDermid, 1997:256). The government only agreed to limited committee hearings on the bill after MPPs refused to leave the legislature until hearings were granted (Fletcher \& Sottile, 1997; Mallan, 2003:H1)

In addition, the government controls the process by regularly invoking closure to both limit and end debate at every stage of the process. ${ }^{12}$ As a tactic to limit giving voice to partisan opposition, the first upswing in the use of closure began federally under Brian Mulroney, used 7.3\% of the time between 1984 and 1988 (Brearton, 2003:6). The Harris government used closure to end debate on a bill $31 \%$ of the time between 1995 and 1999 (Mallan, 2003:H1). A major piece of legislation can become law in Ontario in as little as five to seven days (H1; Brearton, 2003:6). Other rule changes also limit debate, for example, debate times have been reduced and opposition parties are only given minimal time to respond to a formal government statement by a minister introducing a bill (Mallan, 2003:H7). These procedural rule changes directly followed a 10-day filibuster by the NDP on the Megacity bill, a case study taken up in chapter 4 .

Fletcher (2003:3) says the government has not only reduced the powers of the legislature, it has "cut back dramatically on consultations with stakeholders and on

12 This tactic is now being used more often federally as well, with its use standing at $30.5 \%$ between 1997 and 2000 (Brearton, 2003:6). 
public hearings." Consultations are now considerably fewer in number and more managed, with strict time limits, and hearings only allotted selectively when advantageous to the government's position (Mallan, 2003:H1).

Interestingly, after the massive sweep of legislative fervour in the government's first year of its mandate, the number of bills has steadily declined and the number of days that the legislature actually sits has also declined (Brearton, 2003:6). As Brearton points out, "if you don't bother recalling the legislature, you needn't worry about opposing views at all" (6). At risk are the "essential checks and balances within a parliamentary democracy" (6). As Deacon and Golding (1994) have pointed out, it is the presence of parliamentary opposition that keeps a political issue alive in media reports and thus in the public eye. In short, changes to the legislative process have changed the balance between the legislative and executive arms of government, with more power being concentrated within the executive (cabinet), endangering the relevance of the legislature itself.

Government communications management has also been transformed and, along with the use of omnibus bills and legislative changes, is part of a 'move fast, hit hard' political strategy (Douglas, 1993:215-238) ${ }^{13}$ that is common to later neo-liberal governments such as New Zealand and Ontario. As discussed earlier in this chapter the locus of authority (from public to private) and the personnel (from private to public) in neo-liberal government communications have changed or intermingled. Fletcher (2003:1) contends that the communications strategies used so effectively by the Conservatives in their election campaigns-"centralized control of a simple messages,

13 Thatcher's government in Great Britain did not use the 'swift attack' approach, one of the factors in the defeat of the poll tax initiative which will be discussed in chapter 4 . 
extensive pre-writ campaigning, heavy reliance on targeted television advertising, the use of 'hot button' or wedge issues to polarize the electorate"- - have now carried over into communications policies and processes structured inside the government's communications operations. Indeed, this has been demonstrated through centrallydirected decision-making in matters of media relations and other communications activities, in the pre-election television advertising in the run-up to the 2003 election and in the communications strategies undertaken by the government. There is another impact of the politicization and centralization of communications in government: it intensifies the blurring of the responsibility of public employees (is to the public or to the government in power?) that is problematic, yet under-theorized, as it concerns the public service under neo-liberal governments. ${ }^{14}$

In following the strategic blueprint laid out in opposition, the government made use of two significant tactics that have come to characterize neo-liberal communications, both of which are still salient: the crisis construction and the communications offensive.

As discussed in chapter 1 , a crisis is a "critical juncture in a country's history when consensus collapses" (Bradford, 1999:21). The economic and social upheaval experienced by Western industrialized nations in the 1970s and 80 s was an opportunity for the New Right to launch a war of position against the prevailing Keynesian paradigm. Critical to this war of position was the co-optation of crisis from a specific national situation to a universalized and endemic problem that threatened stability. Even when there is no crisis, one can be constructed (Hall et al, 1978; Williamson

14 This is an important area for further research that has not been pursued in this thesis. 
1994). In Canada, the spectre of crisis found expression in the discursive strategy of what can be called "deficitism" (Weinroth, 1997:54) or simply "the debt debate" (Klein, 1996:3). It was supported by the publicity and legitimating efforts of elite neoliberal interests in the United Kingdom, the United States and New Zealand who shared their experiences and offered advice (Douglas, 1993; Kelsey, 1995; Thatcher, 1995; Klein, 1996; Dobbin, 1998). This intersected with "popular discussion in the media and in business circles of government 'debt walls', citizen 'tax backlash', 'welfare cheats', and the like" (Bradford, 1999:21). In Ontario, the Conservatives used the preconditioned environment of deficit crisis as a catalyst to restructure and redefine the province economically and socially (Weinroth, 1997:55). The pretext of crisis was also used to formulate communications strategies and messages that relied on the discourse of debt to convey the seriousness of the crisis, fix it as "truth" and frame it as a debt issue (Workman, 1999:65). The authoritativeness of this discourse structured a simple, coherent and often repeated message, borrowed from Thatcherism, of 'there is no alternative' to widespread economic and social reform —and no need for one.

The 'crisis' was the pretext that allowed for ideological communications offensives to ensure the necessary disciplining - -harsh medicine, as it were—of the state and public. These offensives, which have also been called "blitzkriegs" (Easton, 1994:171) and "seismic legislation" (Isin, 1998:179), represent a particular form of political communication at the beginning of the formal policy cycle (presentation of the policy). A normal policy cycle goes through several stages in sequence, including hearings that allow the public to enter into the process, and ending when legislation associated with the policy comes into effect. In contrast, blitzkriegs are "a rapid thrust 
across a broad front, deep into reform territory" (Easton, 1989b:171). They also have the sense of speed and surprise and are understood to be ideologically-based (Easton, 1989; Golding, 1991; Scott, 1997). A blitzkrieg is not a single, stand-alone initiative, but a package of policies integral to the government's agenda. The metaphor itself captures the sense, "not of public communication at all, but virtually an act of war with associated propaganda" (Atkinson, 1994a:195). A blitzkrieg is a trade-off between successful, short-term manipulation of the public and setbacks in the implementation and possible reversal of policies in the long-term (Atkinson, 1994a:212). When blitzkriegs falter or fail-which of course they can do, as Deacon ND Golding (1994) and Scott (1997) clearly show-it is often only a temporary setback. ${ }^{15}$ After the blitzkriegs are over, the economic and ideological direction they set is broadly followed, regardless of a change in lead actor or government (Easton, 1989; Schwartz, 1997).

In keeping with the focus on hegemonic rather than political communication, the impact of blitzkriegs on legitimation needs to be examined. Blitzkriegs seem to run counter-productive to a government attempting to gain and maintain consent. On the positive side for the government, blitzkriegs do not allow the media sufficient time to evaluate complex proposals or the public to organize effective resistance (Easton, 1994). Both of these will have a significant impact on how government initiatives are shaped and perceived through agenda-setting and framing. Kelsey (99:104) suggests there is a long-term negative impact of blitzkriegs on political legitimacy, as in New Zealand where pressure from the public eventually led to two referenda and a more

\footnotetext{
is The fallback strategy of a blitzkrieg failure can be incrementalism. Health reform failure in both the UK and New Zealand (the latter after a blitzkrieg) may point to the difficulty in using the blitzkrieg strategy in entrenched sectors (Atkinson, 1994a:232). Canada's "cascading privatization" of health confirms this (Armstrong in Browne, 2001).
} 
democratic form of government representation. Similarly, Atkinson (1994a:212) believes the cost of blitzkrieg policy-making is likely to be paid later in setbacks in the implementation process and policy reversals that arise from insufficient consultation.

There are two reasons why blitzkriegs work well for neo-liberal governments. First, a pre-conditioned environment, such as existed in Ontario, carries with it a considerable measure of elite legitimacy, in other words, consent for the Ontario neoliberal project was already won in the spheres where it mattered most: the federal financial and business sectors and the rest of the corporate elite. The Conservatives' own pre-election strategy also served to recruit consent. Second, blitzkriegs are a tactic to gain not consensus but sufficient consent to gain a 'toe-hold' and continue the neoliberal project. They act as the initial offensive-vitally important, but within the context of the larger neo-liberal project: "The most difficult part of a reform program is not introducing the reforms but sustaining them until they have a chance to bear fruit and thus generate political support from the potential beneficiaries" (Williamson, 1994:20). In other words, all that is needed is a favourable balance of forces in the short-term to render the reform more plausible in the medium-term (Jessop, 1989:2901).

The experience of Ontario with neo-liberalism is a good example of the specific tactics and strategies, such as blitzkriegs, transferred from neo-liberal, hegemonic projects in other jurisdictions. More broadly, it is an example of Gramsci's theory of hegemony in action, starting with the war of position, the "gradual, sophisticated strategy" (Ransome, 1992:27) waged by the Progressive Conservatives prior to taking power. 


\section{The State: The Media and the Political Process}

Governments are both dependent on and dominate the social production of news in a mutually reinforcing relationship with the media. A novice government such as that in Ontario in 1995 that seeks to shape a new economic and social reality must rely heavily on news making processes. In recent years, the government's ability to dominate media agendas has arisen largely out of the spectacular growth in resources and people dedicated to public relations (Bennett, 1988). This enables governments to present their views through the media to the public in an attempt to influence perceptions of political events through the media (Blumler, 1990).

Controlling political images is a primary goal of politics and may mean the difference between success and failure. As Tiffen (1989:3) writes, "politics is the only sphere where publicity is the sine qua non of successful role performance." This intensifies the interdependence of media and government: journalists depend on official news sources for their political messages and politicians construct the messages that appeal to journalists (Blumler, 1990). This takes place against a backdrop of institutionalized access, wherein the government makes it easy for the media by providing them with "institutional accommodation" (Tiffen, 1988:33). Thus, the media logic is "the dominant force to which other institutions conform, including the entire political process, which is not inextricably tied to the logic of media work and has been transformed by it into an extension of media production... The media actively help to constitute reality, even if it is only by helping to make 'real' the ways that dominant social institutions structure social and political processes" (Alheide \& Snow in Hackett \& Zhao, 1998:120-121). 
Yet, there is another emerging logic that also constructs government-media relations, and that is the logic of populism and direct democracy. While government sophistication in media and public relations techniques allows it to use the media for purposes of persuasion (Keane, 1991:106), neo-liberal governments increasingly bypass the media production process, which allows reporters and editors more autonomy to frame the issue, and attempt to persuade citizens directly (Underwood, 1998:185-6). Direct democracy in its traditional populist forms can take the form of referenda, town hall meetings or talk radio; in its more technologically advanced forms, it can include political advertising (because it bypasses news media processes) and two-way, Internetbased communication (186). The Ontario government bypasses news media processes through advertising, as has been discussed in this chapter, and through mass-distributed 'householders' on various issues that provide updates on the issues and positions that it wishes to highlight, while also promoting the government. ${ }^{16}$ These householders supply a passive form of populist feedback. In a recent development that is outside the 19951997 time-frame of this thesis but difficult to ignore as an example, the government also bypassed the legislature by announcing its 2003-04 budget via television at a facility donated by a private company. It was the first time in Ontario history that a government budget was presented outside the legislature. ${ }^{17}$ Unmediated government-

\footnotetext{
16 Householders since the government came to power in 1995 include: an update on education issues ("Report to Parents"); a report on social assistance ("Making Welfare Work"); a survey on health care ("We want to hear from You"); and an ongoing magazine-format newsletter on various issues ("On"). Three householders, two health and one budget-related, were distributed across Ontario in a one-month period leading up to what was expected to be a spring election call in April 2003. Most householders include a tear-off reply card asking for feedback and providing more information. Such 'fulfillment pieces' are a standard device used by marketers to build consumer data bases and have been used by this government to 'inform' respondents about later government initiatives.

17 The company, Magna International, and its affiliates donated $\$ 175,300$ to Conservative candidates, including Premier Ernie Eves, in his leadership race in 2002 (McKay, 2003:A9). Former Premier Mike
} 
to-public communication allows for a more clearly ideological message unhampered by interpretation-again, formerly an attribute of partisan politics rather than government communication-which has changed the political discourse in Ontario to a more polarized rather than consensual discourse (Fletcher, 2003:1,3). The Speaker of the Ontario Legislature (himself a Conservative) subsequently ruled that in so doing, the government "undermined parliament and subverted democracy" (Benzie, 2003:A1). He also called the off-site presentation a "one-sided public relations event" that diminished respect for parliament (A1). This example shows clearly the limits of communications tactics to gain hegemonic consent.

\section{The Public Sphere: Social Citizenship and Neo-Liberalism}

Changes made by the centripetal state to access to information laws, election financing, legislative practices and consultations, and government communications have provided a systemic basis for a redefinition of 'citizenship' by controlling information flows and other common sense understandings of how everyday life functions (Mosco, 1996:243).

Citizenship is a good starting point to discuss the public sphere, the site in which and the processes whereby citizens exercise their citizenship. Citizenship assumes equality rights both before the law and in practice, and should be flexible enough to incorporate difference (Reilly, 1996:28-9). According to Hall and Held (1989:175), 'issues around 'membership'-who does and who does not belong-is where the politics of citizenship begins." Social movements expanded claims to rights and entitlements, and in so doing, repoliticized citizenship and its membership (Hall \&

Harris is on the Magna board of directors, while former Premier Bill Davis was a board member for almost 20 years until recently retiring (Carr, 2003:E2). 
Held, 1989:176). Over time, different groups have benefited from the inclusion and exclusion of other groups as 'members.' The public sphere is where these and other debates about politics and society take place (Reilly, 1996:29).

Under neo-liberal governments, citizenship and the rights it embodies are once again being transformed. Membership and commodification are two issues that constitute the new politics of citizenship. Membership as the first of these two issues is replaced by marginalization of segments of society that formerly comprised the recipients of welfare state benefits: the poor, refugees and immigrants, and vulnerable people with particular needs (Sears, 1999:101). Ontario government policies targeting cutbacks to social assistance recipients was a 'hot button' issue in the Common Sense Revolution election campaign document (CSR, 1994:11). As Moscovitch (1997:83-4) points out, the document implied that generous benefits rather than the recession or unemployment were the principle reason for the rapid increase in social assistance cases and accompanying costs. The CSR also promised to guarantee continued assistance to disabled people and senior citizens, implying that these groups were deserving recipients, unlike the others (Moscovitch, 1997:84). This set the tone and boundaries for subsequent government announcements of cutbacks that divided the 'deserving' from the 'undeserving.'

The second issue in the new politics of citizenship is commodification: "The increased importance of market consumption has created new... forms of inclusion in capitalist society that have to some extent superceded social citizenship" (Sears, 1998:103). Citizenship is redefined in a narrowing circle from citizen to consumer, and consumers are the useful, contributing, 'deserving' members of society. Golding 
(1994:15) calls the substitution of consumption for citizenship "inherently a denial of membership of a public realm." From cost-recovery on access to information requests to privatization of Ontario Hydro, the Ontario government upholds a market orientation to the 'business' of government. The "shift from consensus-based politics to a polarized discourse" (Fletcher, 2003:1) in Ontario confers the right of inclusion through ability to consume - to pay one's way-since a consumer is also likely to be a taxpayer. This is juxtaposed against exclusion, the price of non-contribution. This changes the boundaries of government responsibility; the government makes itself accountable to consumer-taxpayers, but not to the 'undeserving.'

The selectivity of inclusion/exclusion is also demonstrated in the strategic alliances neo-liberal governments form in order to create a balance of forces sufficient to create a consensus for their policies. A 'strategic alliance' is a corporate term that is essentially a partnering strategy of mutual benefit between partners. It is really a 'contracting-out' strategy for business that encapsulates the market approach to government: "[T] here is a trend in big business to stick to core competence and let outsiders help in the areas that are not a core strength... One of the best reasons to build a strategic alliance is to allow your business to concentrate on what it knows rather than what it doesn't" (Rigsbee, 2000:187). Unlike the ongoing and long-term concessions or benefits negotiated between governments and sectors under the Keynesian post-war compromise, strategic alliances offer reduced, more narrowly defined and 'one-off' benefits that carry an element of contingency (McBride, 1992:22). A strategic alliance is negotiated as needed between or among equal partners. This concept is superficially similar to Gramsci's relation of political forces; it builds solidarity among groups and, 
eventually, creates a historic bloc. But while Gramsci's concept is organic and intended to build a historic bloc, the government has the power to arbitrarily choose the component partners in its alliances, partners with whom it shares short-term interests. The ideology of strategic alliances is that there is no ideology; each alliance is separately constituted and possesses only its immediate context. These are the kinds of ever-fluctuating alliances-also called "alliance capitalism" (George, 2001:187) or "electoral coalitions" (Woolstencroft, 1997b:50)-that the Ontario neo-liberal government puts together to gain sufficient consent for its policies: "In the era of the limited state and increasing individualism, parties will avoid being caught in the interest group arena as they seek to build successful electoral coalitions by appealing to individual citizens" (50). Such strategic alliances are a radical change from the "coalitions of interests" (Simpson, 1984:xi) that have been used by Canadian Conservatives in the past in order to build beyond their core support and form governments. Unlike the alliances used by the Harris government, those alliances were constructed within brokerage politics that were intended to both secure and maintain a government throughout its term. The current use of strategic alliances as a strategy points out how even negotiated consent is double-edged for the Conservatives. By using such alliances, they signal they can achieve their goals regardless of other circumstances. In effect, the consent they receive is also coercive.

At the same time as the government forges strategic alliances, its selectivity does not include what the Ontario government calls 'special interests.' This kind of sectional interest-whether union or interest group -is believed to want "unjustified privileges" (Mulgan, 1992:256) and is rejected in favour of the 'public interest.' 
Business interests, however, are not seen as 'special interests,' but neutral voices. ${ }^{18}$

This effectively marginalizes organized alternative voices, some of whom once were included in policy formulation under previous governments. Jacek $(1997: 308,325)$ contends that in response some interest groups in Ontario have changed their focus from lobbying to become more like a social movement, as seen, for instance, in the Days of Action that took place throughout Ontario between 1996 and 1998.

\section{The Public Sphere: Social Movements and Resistance}

Hall and Held (1989:177) have said that "citizenship rights establish as legitimate sphere for all individuals to pursue their actions and activities without risk or arbitrary or unjust political interference." This right to citizenship guaranteed by the state is also "a guarantee against the exercise of state power" (177). The restructuring of the state in Ontario has fostered the contentious collective action at the base of social movements (Tarrow, 1998:2) that rejects the narrow redefinition of citizenship of the neo-liberal government. Not every citizen-based confrontation is a part of a social movement and many challenges to the Ontario government have been short-lived, limited expressions of discontent. Collective action becomes contentious when "it is used by people who lack regular access to institutions, who act in the name of new or unaccepted claims, and who behave in ways that fundamentally challenge others or authorities... When backed up by dense social networks and galvanized by culturally resonant, action-

18 It should be noted, however, that the Ontario government's distrust of special interests extends to 'pure' lobbying from all sources (Jacek 1997:308, 325, 326). But "privileged business interest associations, such as the Ontario Chamber of Commerce" are not considered lobbyists. It appears to be a matter of definition. Business interests participate in government business in different ways, taking on formerly government-based administrative functions in a role Jacek calls "private-interest governments" (310). 
oriented symbols, contentious politics leads to sustained interaction with opponents" (Tarrow, 1998:2-3).

Such active social networks are important because, as Golding (1991:519) writes, a "substantial, powerful and articulate social sector" can significantly limit "hegemonic triumph." This puts into perspective the Trilateral Commission's 1975 report that said governments were being overloaded by citizen demands that took the form of increasing participation in political activity, the development of new groups, a diversification in tactics by groups, the increasing expectation that government is responsible for meeting their needs and an escalation of what those needs are (Crozier, Huntingdon \& Watanuki, 1975:162-163). In other words, the commission was concerned about 'too much' democracy. Seen in this light, the deregulation and other restructuring undertaken by neo-liberal governments are a response to the 'threat' and potential conflict from burgeoning demands of a strengthening social sector. ${ }^{19}$ The 'divide-and-conquer' and 'inclusion-exclusion' 'strategic-alliance' approach of neoliberal governments in effect "delegitimizes virtually all claims-makers whose objectives are not directly linked to the accumulation of capital" (Harder, 1996:42).

Gramsci's theory of hegemony resonates with the struggles of social movements to open up or reclaim space in civil society. In the Gramscian paradigm, there is an explicit understanding that a tension co-exists between the rights and freedoms granted by the modern state and the other inequalities in industrial societies (Carroll, 1992:9). Power and the consent to wield power are organized and exercised in state apparatuses

19 Citing the case of deregulation in the United States, Mosco (1998) says this response to the success of non-dominant groups in applying pressure to implement public interest values is "one way the state reforms itself to eliminate an arena of potential class conflict" (Jakubowicz, 1993:41-42). 
and throughout other institutions of civil society. Thus, consent is won in ideological struggle in an ongoing process of constructing and maintaining hegemony, which gives it the sense of both the existing dominant hegemony and, importantly, a transformative counter-hegemony (Carroll, 1992:9, 11).

Carroll and Coburn (2003:90) point to a pattern of development in critical social movements, developed by Magnussen and Walker (1988), that complements (but is not equivalent to) Gramsci's levels or moments in the relations of political forces (1971:180). Movements originate in struggles of specificity that are local and singleissue based (Gramsci's economic-corporate phase in which people stand together but with a sense of obligation rather than solidarity). If the issue persists, these struggles become struggles of connection in which connectedness with other groups is explored (corresponding to Gramsci's second level in which people feel solidarity with their own group). Struggle may then lead to struggles of imagination in which people rethink the meaning of terms, identities and social relations (akin to Gramsci's third level in which people become aware of the interests behind relations and bring about economic, political, intellectual and moral unity). Magnussen and Walter's conceptualization thus seems to stress a Gramscian approach to social movements that provides insights into how movements can create the conditions conducive to building a historic bloc, which is critical to transforming a movement into a political and hegemonic force that can challenge an existing construction of social relations. Gramsci's war of position then comes into play as a strategy of transformation. Since the role and goal of social movements is to challenge such existing social relations, they can be viewed as counterhegemonic or 'oppositional' in the sense of opposing the existing order (Carroll, 
1992:10). In addition, and importantly for the purposes of this thesis, social movements can illuminate "oppositional practices in media and communication" (Mosco, 1996:97).

Gitlin (1980:254) positions the cultural industry as one of the foremost institutions in the "production, relaying, and regearing of hegemonic ideology." The hegemonic role of the media lies in its ongoing capacity and ability in "absorbing and domesticating conflicting values, definitions of reality, and demands on it" (256). Cassidy (1992) contends that the problem encountered by social movements in using the media to promote their claims is that they "seek to challenge the dominant ideology through an institution that plays a vital role in the dissemination of that same ideology" (160). Yet, at the same time, hegemony is not airtight; if it were, social movements would never be able to challenge the worldview presented by the media (160). At stake in this active contest between social movements and the dominant hegemony is the right to shape meaning (Tarrow, 1998:21-2).

Social movements themselves are formed in struggle, both internally and between movements (Bleyer, 1992:115) and there is no single counter-hegemonic meaning system, as each struggle has its own historical and national context (Klandermans \& Tarrow, 1988:23). As laid out in chapter 1, Williams (1977) distinguishes among dominant, alternative and oppositional meaning systems. While the dominant meaning system holds hegemonic sway, "it has continually to be renewed, recreated, defended, and modified" (112). At the same time, the dominant meaning system is "continually resisted, limited, altered, challenged" by "alternative" forces, which struggle with the dominant meaning system within the hegemony, and "oppositional" or counter-hegemonic forces, which struggle outside the hegemony 
(112-114). This is a useful way of grouping the social actors in their struggle that helps to explain the contestation among non-dominant challengers to the social order and, possibly, some of their 'failures' to achieve their goals (this will be discussed in chapter 4).

In one important way, the new social movements and their politics have changed since the wave of movements prior to the $1960 \mathrm{~s}$ and $70 \mathrm{~s}$. Where formerly social movements were "conducted in areas of material reproduction,... the new politics are in areas of cultural reproduction... and involve issues of quality of life, equality, individual self-realization, participation and human rights" (Habermas, 1981:33). Although the new social movements do not necessarily reject class-based or classdriven positions, they insist on a politics with a broader social base (Leys, 1992:4-5). Offe (1985a) agrees that the new movements lack a specific class character, but instead. are tolerant of a wide variety of beliefs. Neither do they believe there is only one field of struggle or one way to change history (Leys, 1992:12-13).

But the new social movements often lack a coherent ideological project or ideological principles (Offe, 1985b:817) at a historical conjuncture where the prevailing paradigm, neo-liberalism, is staunchly ideological and operating both nationally and transnationally. Conway's (2000) analysis of the Metro Network of Social Justice (MNSJ) underlines how an educational and political project backed by 250 member organizations in a coalition loosely bound by "a broad and vague commitment to social justice and a recognition that new times were requiring new approaches to their historic concerns" (45) within an effective war of position could still flounder in the struggle against neo-liberalism in Ontario. Although the MNSJ's problems were complex, they 
revolved around conflicts between a perceived need for action against a perceived need for education, roughly equivalent to a conflict between pursuing a war of movement (manoeuvre) and a war of position. An underlying problem to some, however, was the lack of coherent ideological (or perhaps hegemonic) vision at a critical conjuncture (developing a post-Days of Action strategy for the coalition).

\section{The Public Sphere: Constructing Legitimation and Consent}

The state's task of constructing consent relies on the institutions and practices of civil and political society. Gitlin (1980), like many others, points to the mass media as a leading force in maintaining hegemony. Alternative and oppositional voices look to the mass media as well for propagation of their claims, but, as has been demonstrated in this chapter, the state has at its disposal many powerful structures and practices of legitimation, making the battle for consent an unequal one. The transformation of the state that is the neo-liberal project has had an impact on the public sphere, specifically through changes to the practices of government structured into the state. It also faces encroachments from other sources that are inexorably connected to the state's legitimation processes: communications technology has an impact on political mobilization; the use of public opinion research changes how government consults the public; elite advice to governments creates a different form of democratic participation; and neo-liberal discourse literally changes the meaning of government communication with the public.

Communications technology has changed how political and election campaigns relate to the public. Campaigns of the past depended on mobilization by forces of 
volunteers, some of whom used telephones to persuade voters, but mostly by large numbers of 'foot soldiers' who went door-to-door. In Ontario, the NDP maintained a large organization to focus on door-to-door mobilization and its higher organizational expenses reflect that focus (MacDermid, 1997:78). This way of voter identification favoured the Left, which relied for its success on a superior knowledge of public opinion gained from personal contact, rather than the force of donations (Ginsberg, 1986:150, 168). The new campaigns use technology, which is heavily capital intensive, and makes it difficult for small, less-financed campaigns of any political stripe to purchase and maintain (Atkinson, 1998:94). Although many factors contribute to an electoral victory or failure, technology has made it easier to reach masses of potential voters and its use as a factor in campaign success cannot be ignored: "The supercession of organization by the new technology may prove to be the functional equivalent of a critical electoral realignment, substantially redistributing power and profoundly transforming political possibilities" (Ginsberg, 1986:151). Changes to the Elections Expenses Act that lifted restrictions on political donations subsequently revealed a wide gap in donations to the three main parties in Ontario. In 1999, the first election since the changes, the Conservatives raised more than $\$ 4.9$ million for their reelection campaign. In comparison, the Liberals raised almost $\$ 1.3$ million and the NDP only $\$ 409,000$ (MacDermid, 2003:1).

A capital-intensive campaign environment also changes decision-making. The old, labour-intensive campaigns were run by interest group leaders, political party and trade union officials, local politicians and others, while the new-style campaigns are run by communications professionals, such as media advisors, public opinion researchers 
and mass marketers (Atkinson, 1989:106). Again, the Conservatives' election expenditures on new campaign technologies such as direct mail and public opinion research show a large gap between the party and its partisan political opposition (MacDermid, 2003).

Much of the impetus for using mass communications technology in campaigns emanated from the United States, where the religious Right used television to develop the "electronic church" (television station ownership and programming) and the use of sophisticated direct-mail technology in order to reach targeted conservative audiences (Edgar 1986:65; Jesson et al, 1988:20). The 1979 formation of the Moral Majority, an activist Christian coalition, brought the electronic church and direct mail together "with an emphasis on broader conservative issues, thus transforming a conservative religious movement into an important political movement" (Jesson et al, 1988:22). These directmail techniques were first used widely in Canada by the federal Conservatives in the 1980s (Drummond \& MacDermid, 1997:203). The use of communications technology to 'mobilize' support in campaigns reduces political contact between citizens and politicians. Although politicians may be better informed about the electorate and better able to make decisions regarding targeting groups of voters to be able to construct strategic alliances, they are also distanced from them.

Public opinion research (polling), another important device used by governments and in election campaigns to gain consent, contributes to this distancing by offering advanced techniques for collecting and assessing what it claims to be 'public' opinion. The public opinion extracted from such research is thus a commodity used "to purchase data in hopes of gaining power, attention, or profit" (Herbst, 
1993:153). It is acquired by governments and election campaigns for a short-term political and ideological purpose- - to secure a bloc of votes or support-rather than for democratic policy making. Polls find out "how various issues 'play' with the electorate ('hot buttons'), and...devise policies to fit existing patterns of evaluation" (Palmer, 2002:353) not create new, democratically-based policy directions. They are a blunt instrument, conducted with the questioner in mind, not the questioned (Atkinson, 1989:91) and more concerned with misinformed or uninformed 'top-of-mind' responses than informed public judgement (Yankelovitch, 1991 :xii; Atkinson, 1994a:214-5). The opinion collected may in fact be social or mass opinion: social opinion reproduces the existing social formations, "thus maintaining legitimacy and power" (Mosco \& Mahoney, 1985:xviii) and mass opinion is opinion "unmediated by group discussion of common interests" (Young, 1985:263). In contrast, authentically 'public' opinionopinion compiled through various democratic processes (such as government-led consultations, task forces, Royal Commissions, town hall meetings, MPs' meetings, etc.) for the purposes of policy development-has the potential power to subvert legitimacy gained through use of social or mass opinion (262).

Public opinion research is not inherently knowing or powerful, but takes its meaning and power from the ideological environment and historical context in which it is used (Herbst, 1993:159). Research findings are used by politicians as "'objective' evidence of the public will" emanating from a "confidential, scientifically conducted survey" $(153,172)$. Polling results are presented as neutral and non-ideological, much the same way as the journalistic paradigm of objectivity underlies journalistic practice, and they have become absorbed into media norms as an authoritative, expert 
information source fitting news values (Frankovic, 1998:150). The integration of news and polling (either polling by private companies supplied to the media as informational subsidies or polls conducted by media in partnership with such companies) gives polling "a special dominance in politics and the coverage of politics" (158). Polls increasingly influence political strategies and often are an organizing framework of campaigns (Craik, 1987:81). This was true of the 1995 election campaign strategy of the Ontario Conservatives, whose pre-election polling and focus groups identified issues which then were incorporated into political advertisements and also underpinned the organization and discourse of the election campaign itself. In fact, the planning that came out of their extensive public opinion research allowed the Conservatives to predict the course of the election campaign itself (Woolstencroft, 1997a:42). ${ }^{20}$ The 1997 election finance act changes then allowed the new government to raise substantially more funds, with which they conducted public opinion research to craft messages in 1999 and then, during that year's election campaign, expensive nightly tracking polls to ensure the messages continued to resonate with the public (MacDermid, 2003:2).

The widespread use of public opinion research to replace the public discussion of participatory democracy merely captures a context-free 'snapshot' of opinion expressed in numbers. As it is currently used for political purposes, it is value-free, context-free, unidirectional information-mass opinion, instead of public opinion. Despite this major shortcoming, nightly or other opinion tracking is of benefit to politicians because it identifies changes and trends that are related to the baseline poll,

\footnotetext{
20 This is confirmed by Ipsos-Reid polling, which shows that much of the changes in voters' allegiances occurred during the election campaign; $39 \%$ of voters said their impression of the Conservatives had improved during the campaign, compared to only $12 \%$ improvement for the Liberals (Ipsos-Reid, 1995a:60).
} 
however inadequate the baseline tracking poll may be in representing true public opinion.

As in the 'blitzkrieg' approach to public communication, neo-liberal governments do not see the need to construct deep, long-term public support in a participatory dialogue offering a range of policy options for discussion, or even a limited set of options, as was common under corporatism. Instead, the favoured strategy of forming strategic alliances requires only the right numbers and voter profiles. In these circumstances, it does not matter if the values of citizens remain static, are on loan or able to be purchased. The puzzlement expressed by analysts (Crewe, 1988, 1989; Edgell \& Duke, 1991) in Great Britain about the lack of change in values after years of Thatcherism may be misplaced: values may not change as long as votes do. In Ontario, public opinion research consistently shows that Ontarians value public health care and public education (Ipsos-Reid surveys, 1995-ongoing), so the values that underlie these state-run institutions-the bedrock of Canadian social programs-seem rock-solid. Yet Ontarians have elected a government whose aim is to restructure if not privatize these institutions and which contends that in so doing a strong economy will result. This dichotomy of opinion will be examined in the case studies in chapter 4.

Elite advice is a contrast to the quantified, uninformed views offered as public opinion in polling. According to Abelson (2002:165), policy makers are increasingly turning to elite advice in the form of think tank-type research organizations for 
"informed debate." Think tanks or research institutes ${ }^{21}$ are composed of elite citizens who replace ordinary citizens at large in policy and decision making (McCormick, 1989:13). The influence of think tanks on policy is difficult to ascertain, but some of these organizations themselves, particularly the Fraser Institute, are convinced of their "central role in most public policy developments over the last decade" (Abelson, $2002: 83,86)$ and indeed their mission is to produce and promote their expertise among policymakers" (Rich \&.Weaver, 2000:81). The work of the MacDonald Commission on the economy in the 1980s is an important benchmark in the influence of elite interests on policy, according to Bradford (1999), who contends that neo-liberal think tank interests "went well beyond parameter setting to take an active role, not simply in ideologically structuring the commission's deliberations and research work, but in directly presenting sophisticated policy blueprints of a new reality" (50). Langille (1987) takes the Business Council on National Issues (BCNI) as an example of the successes an aggressive organization can have. Motivated by a perceived need to increase competition internationally without the profit-limiting concessions and compromises of corporatism, BCNI "organized the power bloc" to influence policy direction on a new competition agreement and on free trade (Langille, 1987:45, 47). The C.D. Howe Institute also played a critical role in "reinforcing and advancing the federal free trade agenda during the 1980s" (Abelson, 2002:193). The National Citizens' Coalition continues its campaign to force changes to the third-party advertising provision in federal election expenses legislation (NCC, 2003).

\footnotetext{
21 As mentioned in chapter 2, this thesis takes a broad definition of think tanks and research institutions to include such corporate groups as the Business Council on National Issues and the National Citizens' Coalition within the corporate circle or hegemonic bloc that also research and promote their views in a away that can also be construed as lobbying.
} 
In fact, the "business activism" of these think tanks has been viewed as "the most important movement" in the late 80s and, further, it was "not a popular-democratic protest, but a top-down initiative, spearheaded by key organizations of the capitalist class and its organic intellectuals" (Carroll \& Coburn, 2003:83-84).

Think tanks have different sites of possible influence. Some opportunities are situated in parliamentary hearings and consultations within the traditional policy cycle. Except in official transcripts, this is a relatively unreported and low-key approach to policy inclusion. In addition to direct participation in the policy, think tanks turn to the media, believing that media exposure is equated with policy influence (Abelson. 2002:83): "Without a public constituency backing their efforts, the influence of expertise-providing organizations often depends on the visibility their research obtains" (Rich \& Weaver, 2000:81). Media visibility still reaches policy makers, who are also media consumers and pay attention to issues mentioned in media coverage (180).

A case study by Abelson (2000) shows the differential access to the media experienced by major Canadian think tanks. Abelson's study covers 15 years (1985-99) of media citations in selected major newspapers, in $\mathrm{CBC}$ radio, and on $\mathrm{CBC}$ and CTV news coverage. Overall, the top five think tanks cited (Conference Board of Canada, Fraser Institute, C.D. Howe Institute, Economic Council of Canada and Canadian Tax Foundation) shared $45.8 \%$ of the citations. The only centre or Left-leaning think tanks in the study (Canadian Council on Social Development, Canadian Centre for Policy Alternatives and Caledon Institute) had $7.3 \%$ of citations among them. ${ }^{22}$ Rankings held across different media, with some regional differences in newspaper coverage.

22 Note that the ideological status of the think tanks in the study was not assigned by Abelson, but added here for the purposes of this thesis. 
Television news differed between the two channels, with CTV significantly less likely than $\mathrm{CBC}$ to cite think tanks and both networks relying on a smaller circle of them. CTV cited the top five think tanks $77.6 \%$ of the time and the centre/Left think tanks only $3.8 \%{ }^{23} \mathrm{CBC}$ cited the top five $63.9 \%$ and the progressive/Left think tanks $10.2 \%$ of the time.

These findings do not take into consideration many factors that might shift perceptions of the coverage, such as length and prominence of quotes and clips, the context in which the citation is situated or, importantly, the efforts made by the think tanks to gain access to the media. There is also the issue, unresolved to date in thinktank research, of separating think tank influence from other influences. In terms of the general public environment, media citations of think tanks have been steadily decreasing since 1991 and 1992, the period when national unity debates and economic issues were prominent in the Canadian public environment (Klein, 1996). Despite the absence of a more in-depth study of think tanks, it is clear that government-sponsored or Right-leaning private think tanks dominate in media coverage, with those private organizations that have made the most claims about their policy input (such as the Fraser Institute) or whose successes in setting the agenda have been noted by others (Langille, 1987, Workman, 1999, Abelson, 2002), in fact, being cited the most. Abelson (2002:97) also demonstrates in his study that the success of think tanks in accessing the media is dependent on the overall budget of the research institute, wherein for the most part larger budgets equal higher media visibility. Of the nongovernment sponsored organizations, the Fraser Institute (FI) and the C.D. Howe

23 The top five cited in television news varied in one respect from the print coverage: The Canadian Tax Foundation was replaced by the Canadian Institute for Strategic Studies (Abelson, 2002: 104-5). 
Institute each have an annual budget of $\$ 3$ million and they are also among the top-cited think tanks in the media. The Caledon Institute has a budget of $\$ 2$ million and CCPA's budget is $\$ 1.5$ million; both are at the lowest end of the cited think tanks (Abelson, 1999, 2002). More Right-wing think tanks tend to allocate more resources to public affairs and promotion (Rich \& Weaver, 2000:85). An example of the Fraser Institute's interest in media visibility is its National Media Archive, established in 1987. The archive is a research unit dedicated to content analysis of media reports, which, according to Hackett and Zhao (1998:103-5), tends to consistently interpret Left bias in the media. The institute also has a comprehensive communications and promotion plan that goes beyond media access. It includes broadening circulation of its journal, Fraser Forum, developing a database of journalists, expanding distribution of material, actively collaborating with press liaison people in other institutes around the world, hosting an international symposium and establishing a seminar program for university students (Fraser Institute, 1996:171-18). The FI has links to the US-based, New Right-oriented Heritage Foundation through its "Economic Freedom" initiatives, which include the promotion of "tax freedom day" (Kelsey, 1999:61).

The work of the Business Council on National Issues and others in the 1980s and early 1990s may have "pre-conditioned policy makers and the public for the neoconservative onslaught" (Langille, 1987:72) in Ralph Klein's Alberta and Mike Harris's Ontario. Positive references to the Harris government abound in think tank literature, and Harris is currently a senior research fellow at the Fraser Institute (Bailey, 2002:A8). Among other pro-neo-liberal articles, Fraser Forum has published accounts by Tom Long, a senior advisor to Harris, and Ruth Richardson, former finance minister in New 
Zealand (Long, 1995; Richardson, 1995). It also dedicated its June 1993 issue to the New Zealand Finance Minister who initiated reforms in that country, Roger Douglas, describing him as a "heroic figure" (Kelsey, 1999:61). As premier, Harris gave speeches to FI (receiving an award at one event) and at NCC gatherings. ${ }^{24}$

In the case of the large, Right-wing Canadian think tanks, the power to construct and legitimate is grounded in material power. The large, well-financed Canadian think tanks have contributed to the strength of the neo-liberal project in Canada and in Ontario through the promotion of neo-liberal ideas and research. As partners in the neo-liberal hegemonic bloc, they have helped the project, already a force through its structural power and financial resources, to "solidly unite... around a coherent program" (Klein, 2996:53).

Neo-liberal discourse also contributes to the legitimation of neo-liberalism. In Gramsci's theory of hegemony, all groups participate in negotiation over meaning. These continuing social and ideological struggles leave "multiple contradictory fragments" in the common sense of the people that emerge as discourse and discursive dominance (Bruck, 1992:152; Phillips, 1996:214). Such emergent meaning systems are in constant movement, uneven and incomplete (Williams, 1977:124), but the "conceptions which organize the mass of the people are worth struggling over, [as] social subjects can be 'won' to a new conception of themselves and society" (Hall, 1988:10).

24 This close relationship does not keep neo-liberal groups from criticizing the Harris government on occasion, usually for not moving ahead fast enough with market reform promises.. In August 2002, for instance, the NCC criticized current Ontario premier Ernie Eves for not proceeding with a promised tax cut (NCC, 2002). 
Hall $(1985,1988)$ has used the concept of "authoritarian populism" to illuminate the different discourses that are condensed into the contradictory formation of neoliberalism. That discursive formation contains the two threads of neo-liberalism: liberal free-marketism (incorporating themes of freedom and choice) and organic conservativism (incorporating themes of tradition, patriarchy and order), which are "purged of their links to particular interests and power blocs and presented as a straightforward matter of common sense" (Hansen \& Murdock, 1985:231).

The moral conservative strand of neo-liberalism underlies this hybrid discourse and is the understated, but powerful, ideological element that resonates with people. The role of the free market is "to chastise the feckless," making it "an instrument not of liberation, but of discipline" (Edgar, 1986:75). State-based moral discipline suppresses permissiveness and deviance through strict "law and order" policies, such as banning 'squeegee kids' from the streets of Ontario (Foster, 2002:37), and directs fears and insecurities in the public into marginalizing portions of the population (Sears, 1999:105), through policies such as dividing the poor into deserving and undeserving in cutbacks to social assistance (Moscovitch, 1997:84). The construction of 'disorderly people' is a central aspect of Ontario neo-liberal restructuring: "Disorder and the people constructed as embodying disorder have become a central resource of political power in Ontario, one that is produced and managed as an essential feature of neo-conservatism across a wide range of government activities" (Hermer \& Mosher, 2002:16). The disorderly include those classed as "squeegee kids, welfare cheats, coddled prisoners, violent youth, aggressive beggars" (16). The government's first expenditure cuts in 1995 included a cut of $21.6 \%$ to welfare assistance and the setting up of a provincial 
fraud line (Ralph et al, 1997:21). The discourse of moral discipline, fanned by government, entices the public to look for culprits on whom they can lay blame for social disorder (Patten, 1996:114). Its very choice of targets for restructuring reflects the politics of exclusion - what Jessop et al (1988) have referred to as the "two nations" manifestation of neo-liberalism.

The disciplinary nature of neo-liberal discourse is also reflected in the freemarket discourse of debt or deficitism that has played a crucial role in constructing stealth neo-liberalism in Canada. Public opinion research in Canada and in Ontario demonstrates the force of debt discourse. In 1997, a majority of Canadians (55\%) felt the federal government was causing "too much pain" in reducing the deficit but $65 \%$ conceded that they would be personally better off when the deficit was eliminated (Ipsos-Reid, 1997f:34). In Ontario, custom polling conducted for the government early in its first mandate revealed that $59 \%$ of Ontarians believed that the spending reductions in the government's first economic statement would help "put Ontario on the right track" at the same time as they agreed (54\%) that balancing the budget would occur "at the expense of those least able to afford it" (34).

The debt discourse contends that the debt is reaching crisis levels and the country will hit the 'debt wall,' unless it is reduced to protect living standards, the private sector is left free of government interference to undertake investment and taxes are cut to stimulate growth (Klein, 1996:60-1; Dobbin, 1998:222). Critical to the debt discourse is the refrain that "there is no alternative" to this prescription:

The logical policy conclusions of the debt discourse-cutback, trim, streamline, dump, etc.-in accordance with notions of fiscal frugality are perfectly consistent with the contours of neo-liberalism... The discourse of fiscal crisis 
allows neo-liberal policies to be implemented with considerable levels of support from all social classes. It has the effect of cultivating a consensual base for the implementation of neo-liberal policies... The consent-creating capacity of the debt discourse derives from its consonance with common sense or popular understanding or shared wisdom... (Workman, 1999:64-65).

Counter-discourses then seem "blatantly ideological, the product of groups with axes to grind who are out of touch with the people and trying to impose their mistaken... ideas on everyone else" (Hansen \& Murdock, 1985:231). Opposition ${ }^{25}$ then tends to stay within the terms of the dominant discourse (Phillips, 1994:217); its rights-based and 'self-interested' attempts at inclusion remain distant from substantive economic questions (Knight,1998:118).

Neo-liberalism appears to have considerable discursive resonance and success in the jurisdictions where it has been encountered (Phillips, 1994:210, 236; Atkinson, 1994b:147). It is common, for instance, for political commentators and media reports to speak in the language of debt and tax reduction, as seen in the reaction to the 2003-04 budget in Ontario. Ontario government announcements generally emphasize market choice in their presentation of new policies and initiatives. In addition, as Phillips (1994:217) points out, oppositional (here the meaning is 'alternative') discourse tends to mimic neo-liberal discourse.

This discursive success is a vital element in the validation and legitimation of neo-liberalism as a new paradigm, however, it may not be matched in the values and beliefs of the Ontario public. The continuing issue of the depth, extent and durability (Gamble, 1993) of the neo-liberal projects that relied on swift 'attack' tactics can be

\footnotetext{
25 As noted in chapter 1, this thesis uses the term 'alternative' to describe contestation that is acceptable in a society, while 'oppositional' describes opposition that is deemed to lie beyond acceptable limits (Williams, 1977). When describing parliamentary opposition, the term 'partisan opposition' will be used. When the term 'opposition' is used by itself, it means general opposition, as does the term 'challenger.'
} 
counterposed against the lengthy and deliberate pre-conditioning of the discursive terrain and its clearer success here. This speaks to the structuring power of language and may help in understanding the various interconnecting spheres that comprise a neoliberal project and the possibilities that they progress towards a new hegemony not only under different conditions, but at different speeds and in different symbolic locations.

\section{The Mass Media: Media Practice and the Construction of Neo-Liberal Hegemony} As conceived by Gramsci, hegemony requires both coercion from above and consent from below. The state maintains its hegemony through its major social institutions, which reproduce the "whole system of values, attitudes and beliefs—ideology—that... supports the established order and [its] social interest" (Hackett et al, 1996:259). The mass media form one of the most influential social institutions of ideological domination. The power of the media lies less in its role as provider of information and more in its capacity to shape perceptions in a way that seems natural and neutral to its audience. Like public opinion research, the 'facts' of media neutrality have the force of 'neutral science' behind them, although both practices are socially and economically constructed.

Media 'objectivity' is an "ensemble of ideals, assumptions, practices, and institutions" (Hackett \& Zhao, 1998:1) that comprises the prime strategic tool of media institutions to ensure this seeming neutrality and thus appear to media audiences as disinterested observation. The impartiality or neutrality of media practice developed historically to "compensate for the loss of multiple viewpoints" as media ownership became less local and opinionated (Atkinson, 1994b:146). In a post-modern world of 
became less local and opinionated (Atkinson, 1994b:146). In a post-modern world of media conglomeration and control, however, the regime of objectivity gives the media "powerful leverage over the language, agenda and perspectives capable of getting a hearing" (146). Rather than reflecting multiple viewpoints, it reinforces dominant definitions of social reality that people accept as common sense and it maintains the fiction of freely given, conscious consent: thus, "the hegemonic function of the media is achieved through the active participation of the audience" (Hackett et al, 269), in the sense that even when audience members negotiate and challenge media accounts, which they actively do, there is often an implicit acceptance of the representativeness or shaping of public life by the media (269) and the challenge is thus not to the right of the media to so shape public life, but difficulties with the specific account itself. In other words, "arguments against 'this' interpretations... begin from this framework of interpretation as their starting point" (Hall et al, 1978:58).

A challenge to the media in the form of a charge of media 'bias' does not expose a failure of objectivity, as this would suggest "a position of objective neutrality from which someone deliberately imparts a deviation" (Golding, 1995). It is the successes of the regime of objectivity that reveal its strength and power to shape public life and create meaning; its failures only make the dominant hegemony visible: "adherence to the norms of objectivity is precisely the means by which the media retain the consent of audiences" (Hackett et al, 1996:168-169). Further, echoing Hall et al, this implicit acceptance "establishes the conditions under which dissent can be voiced" (269).

Although they help to shape, reflect and maintain the dominant hegemony, media operations are not without conflict or contradiction that can create openings for 
non-dominant ideological reproduction, that is, the voicing of dissent (Bruck, 1992:140). The bureaucratic organization of news reinforces objectivity and dominant views at the same time as journalistic norms require that the media "permit-indeed, may insist on - the entry of challenging social movements into the public ideological space" (Gitlin, 1980:259). Thus dominant ideological closure in the media is not absolute and ideological failures do occur (Deacon \& Golding, 1991:311), emphasizing that media are not all powerful, but a powerful player.

Although dissent may enter into the media discourse, it does not necessarily receive the same treatment as authoritative, dominant sources. As politics is normally defined electorally in a democracy, the non-electorally-based work of dissenters and social movements is considered "theatrical, irrelevant, or even irrational and illegitimate" (Hackett \& Zhao, 1998:149). An aspect of dissent under neo-liberal governments is the use of an authoritarian or 'law and order' discourse that, when present in media accounts, serves to depoliticize and remove dissent from its context within its structuring political, economic and social conditions (Mosco \& Mahoney, 1985:xvii).

Framing and agenda-setting are two explanatory concepts for understanding how the media fulfill their hegemonic role of legitimation and consent. Framing refers to the way the reporting of an issue or event is shaped that directs to a particular interpretation or preferred reading of a situation or object (Perloff, 1998:237; Jasperson et al, 1998: 206). In other words, "events have to be made to mean by being placed in a context considered appropriate" (Hackett \& Zhao, 1998:119). Analysis of media frames shows that they are not objective and neutral extensions of the objectivity ethos, 
but contain "reality judgments and normative values [that] unavoidably intrude upon the selection of events, language, and interpretive context" (120).

An example of how framing can reveal influences is a case study on television news coverage of poverty in the US between 1981 and 1986 during the Reagan presidency (Iyengar, 1997:280). The study found that when the media framed poverty in a broad context (a thematic frame), an audience attributed responsibility for poverty solutions to government. When the media framed poverty as an individual story (episodic frame), the audience blamed the individuals. In political terms, this initial experimental study suggests that a focus on individualism can contribute to a construction of self-reliance that relieves the state of responsibility for broad social problems. This would be of interest to neo-liberal governments in their communications efforts to promote policies that reduce citizen reliance on the state. In the Iyengar study, for instance, evaluations of President Reagan were significantly lowered among participants who tested as having a stronger sense of social responsibility (277-278).

Agenda-setting is a process in which the media assign prominence to certain issues in the information environment (Perloff, 1998:208; Jasperson et al, 1998:205). The media do not necessarily set agendas on their own, but "build on pre-existing agendas that... have already been mapped out by other political and social agencies" (Perloff, 1998:226). Agenda-setting thus acts in multiple sites and can be driven by the public, the media or government at different times. ${ }^{26}$ The role of the media in setting

\footnotetext{
26 In Canada, governments have extensive agenda-setting power, due to the institutional structure of the parliamentary system. Policy 'windows' may open and close in accordance with institutional, electoral and political cycles in which political events tend to drive policy cycles (Howlett, 1997:27-28).
} 
agendas is laid out in the classic proposition that the media may not tell us what to think, but they tell us what to think about (Cohen in Deacon \& Golding, 1994:197). In other words, the media don't lead public opinion, they reinforce it. For instance, the media can set the agenda when public opinion converges—both dominant and challenger opinion-against a government initiative. This leads the media to doubt and rethink dominant framing (Negrine, 1996:180). When this occurs, government political communication efforts may not be sufficient to ensure hegemonic reproduction and the media have more agenda-setting influence (Deacon \& Golding, 1994:199-200).

Hegemony is constantly being contested by alternative and oppositional meaning systems. As part of the hegemonic apparatus of society, the media help to reproduce the dominant values and meanings, but are also subject to the continuous struggle for meaning from non-dominant sources, as hegemony by definition is always dominant, but never total or exclusive (Williams, 1977:113; Mercer, 1980:105). These non-dominant elements of society — the alternative and the oppositional — are always present and the dominant hegemony needs to be continually responsive to them (Williams, 1977:113).

The division of meaning systems into dominant, alternative and oppositional is useful for examining the nature of their relationship to the media. The concepts of primary definition and accredited access elucidate the differences. Accredited access refers to the structured preference that powerful and credible actors have to the mainstream mass media because of their powerful or privileged institutional positions in society (Hall et al, 1978:58). Their systemic over-access to the media allows them to offer their opinions, thus providing the "primary definition" of an issue (58). According 
to the primary definition hypothesis, journalists generally circulate these definitions or preferred interpretations of issues in their news accounts, thus internalizing the dominant power structure and reproducing symbolically its values for the public. While alternative viewpoints appear in the media, they are generally represented in relation to primary definers and primary definition. Because of their structured relationship to power, the mainstream media as "secondary definers" are conduits of power or carriers of dominant ideologies. In this way, the media "construct a particular image of society which represents particular class interests as the interests of all members of society" (59). ${ }^{27}$ Primary definition is not without contestation within the dominant power structure and should not be taken as uncontested within the groups struggling for access. It is less a characteristic of elites than a process, albeit one played on an uneven field (Deacon \& Golding, 1994:9).

Within the narrow circle of powerful actors with over-access to the media, official or government sources account for a majority of reporter-source interactions (Ryan, 1991:128; Schudson, 1991:148). In her study, Tuchman (1978:81) observed journalists seeking out centralized sources, politicians and bureaucrats, but never leaders of social movements or grass-roots organizations, at the same time as they created a "web of facticity" that framed their work as objective. Gans (1979:126) noted the media tended to draw on "a small and narrow aggregate of sources dominated by regular contact." In short, it is axiomatic that the news represents authority, which divides the "authorized knowers" from the excluded (Ericson, Baranek \& Chan, 1989: 3-4). Thus, officials hear "echoes of their own voices and reflections of their own

\footnotetext{
27 Among those who have refined and extended these concepts are: Schlesinger (1990), Glasgow University Media Group (1993), McNair (1994) and Negrine (1996).
} 
images" in news accounts (Sigal, 1973: 187). This clearly points to the mass media as legitimating the dominant hegemony, positioning them as an important adjunct to government and other established authorities.

Under these conditions of structured access, official sources are holders of considerable power, with the most powerful in a position to reciprocally manage and control the media. Alternative and oppositional organizations, on the other hand, must continually struggle for representation and legitimacy. As Hall (1986) has said,

Some things, people, events, relationships always get represented: always centre-stage, always in the position to define, to set the agenda, to establish the terms of the conversation. Some others sometimes get represented-but always at the margin, always responding to a question whose terms and conditions have been defined elsewhere: never 'centred.' Still others are always 'represented;' only by their eloquent absence, their silences: or refracted through the glance or the gaze of others (9).

In addition to the limitations of their non-dominant structural and ideological position, the ability of non-official sources (either alternative or oppositional) to gain access to the media depend on a number of practical factors, such as geographic proximity, budget, human resources and communications investment (Deacon, 1996:184). There is a close link between economic power (budget) and media prominence (191). Alternative groups will have considerably more access to and visibility in the media than oppositional actors, due to the non-threatening nature of their claims and the acceptable expression their opposition takes. Examples of such groups include the challenger groups from the case studies in this thesis. During their respective struggles against the government, Citizens for Local Democracy and People for Education routinely received media coverage. Oppositional groups, on the other hand, have less success in gaining routine, sustained and positive media visibility, partly because many 
such groups to do not work within socially negotiated frameworks (that is, they do not necessarily use news releases or hold news conferences, as would alternative groups) and their tactics often include "direct action casework" (Clarke, 2003:1), as in taking over unoccupied houses to draw attention to homelessness. An example of an oppositional group is the Ontario Coalition against Poverty (OCAP), which usually receives media coverage that promotes an image of violence and disorder, such as the recent trial of three OCAP members for allegedly inciting a riot at a Queen's Park protest against the government.

Media practice - -the bureaucratic organization of the media and its journalistic norms - is also influenced by the organization of media institutions as "commercial enterprises governed by the logic of capital... and profit accumulation" (Bruck, 1992:139). Audience maximization thus overdetermines operating factors and puts pressure on "the imperatives that justify and legitimate programming, corporate plans, and resource allocation" (139).

The US experience, echoed in Canada in recent years, shows that corporate takeovers have a detrimental impact on news departments (Hackett \& Zhao, 1998:65; Underwood, 1998:171). Television public affairs coverage has given way to 'soft,' ratings-driven content and reporting staff have been downsized, as have bureau operations and public affairs documentaries in order to make room for programming with more entertainment value, such as government scandal (Underwood, 1998:172-3). Newspapers show more of a focus on lifestyles at the expense of news about government (175). A recent phenomenon is market research conducted within the news 
industry to gauge reader/listener preferences (176). The new, corporate newsrooms are also likely to be run by "manager-technocrats" (176).

In Canada, recent signs of more corporate, centralized media operations can be demonstrated through the changes to CanWest Global after its most recent acquisitions. CanWest Global includes 29 television stations, 187 newspapers and other publications and 7 Internet operations (CPBF, 2002:5-8). Its original and continued major holding is Global TV, based in Ontario. This includes major holdings in most large Canadian cities. CanWest Global centralized its operations in Winnipeg, including the assignment and editing of editorials (Mills, 2003:B11). In December 2001, when the new editorial policy went into effect, Montreal Gazette reporters in an open letter called the move "an attempt to centralize opinion to serve the corporate interests of CanWest" (ONG, 2002). In March 2002, at the Regina Leader-Post, a story critical of CanWest was altered by Winnipeg, and CanWest reporters across the country received a letter warning them not to make "unfounded and inaccurate comments about the company" (ONG, 2002:1). Several other incidents of journalistic 'chill' in the CanWest operations have also been reported (4), although negative publicity, led by journalists, has quelled their incidence.

In addition to the tension between local and centralized news making, economic restraints and new technologies have had an impact on news labour. With the media under corporate ownership, in technologically modern newsrooms, run under business strategies established centrally and working to "cross-chain, bottom-line figures," studies in Canada and the US show that news workers who still have jobs are now serving the needs of profit rather than communities (McKercher, 2002:31-32): 
"Newspapers are owned by corporations whose loyalties and responsibilities lie with their stockholders rather than with local readers.... Increasingly, they see readers as customers or consumers, rather than as neighbours and fellow citizens" (33).

Objectivity, framing and agenda-setting, primary definition and accredited access, the managed newsroom-all demonstrate the influence of dominant elements in society offering official definitions of social reality which privilege and legitimate their own interests. This leaves little room or desire for alternative or oppositional views of reality, "unless the organizations stage photogenic or disruptive protests. And although it sells newspapers (and advertising), protest that goes beyond what the media present as responsible, serious, and legitimate politics is almost automatically discredited" (Hackett et al, 1996:267).

\section{The Mass Media: Media Systems and Commercialization}

In Canada, despite the continued importance of public broadcasting, most mass media are privately-owned, profit-oriented, advertising-based corporations (Hackett \& Zhao, 1998:64). The mass media thus constitute a corporate elite that provides media content as a business cost, rather than as cultural and political expression in the public interest (Hackett et al, 1996:65, 260).

Canada's mass media are among the most highly-concentrated in Western industrialized nations and have very large media conglomerates, which have holdings in different industries (Hackett et al, 1996:261; McKercher, 2002:5). The example of CanWest Global shows how media concentration has intensified and diversified to 
include different media within one corporation or conglomerate. Across Canada, there are now only 51 owners of media corporations, 16 of them in Ontario (CPBF, 2002).

The growth of concentrated ownership is fuelled by the financial gain that usually comes from a monopoly market (Hackett \& Zhao, 1998:63). Other businessoriented reasons for pursuing acquisitions and mergers are also strategic-protecting one's interests in a market, seeking larger audiences, reducing risk and downturns from business cycles, demonstrating growth to financiers-but all are intended to lead to higher profit (Picard, 1998:197-200).

The commercial logic of mass media concentration has an impact on media content. Abuse of power by owners directing editorial content is an issue, from Rupert Murdoch's press campaign to elect Margaret Thatcher (Ginsberg, 1986) to CanWest owner Israel Asper's centralized editorials promoting his view on Israel-Palestine relations (Mills, 2003:B11). The economies of scale possible from media concentration-such as common editorial policy and common, centrally located staff (Hackett \& Zhao, 1998:66) —also tend to homogenize content, as much of news and information originates from the same sources and stories that are repackaged and reused (Picard, 1998:210). Homogenization also promotes a depoliticized 'generic' point of view, with "political values expressed... increasingly... implicit and hegemonic (dominant and consensual), rather than explicit, abrasive, and partisan" (Hackett \& Zhao, 1998:67). Another aspect of homogenization is the emphasis on mainstream voices and the marginalization of diversity and dissent in the pursuit of controversyfree, consumer-oriented content that will not offend (Picard, 1998:210). Content that doesn't offend is a step away from content that pleases advertisers, who supply the 
revenue that makes the business of news possible: "[T]he result is further blurring of the lines between news, entertainment and promotion" (CPBF, 2002:2) or "news that sells" (Picard, 1998:211).

Objectivity is the ideology that, although articulated differently in 'quality' newspapers like The Globe and Mail (where 'expert' and authoritative opinion are heavily used) from populist newspapers like The Ottawa Sun (in which 'the people' or readers are the experts) allows them to speak from "the universalizing perspective of common sense" (Hackett \& Zhao, 1998:69). This common sense of commercialism, however, continues to under-represent diversity and non-mainstream viewpoints, as was once pointed out by the Kent Commission on Newspapers (Hackett \& Zhao, 1998:69).

New corporate media manifestations like convergence and fragmentation exacerbate issues of media content. Convergence is the merging of technologies, corporations and cultures (Taras, 2001:61) for capitalist accumulation, represented by more profit and control over the relations of production, reproduction and consumption (McKercher, 2002:3). It extends the 'horizontal' control of ownership and concentration to the 'vertical' control of cross-media ownership (Taras, 2001:71) and beyond, to the 'diagonal' control of integrating media forms and products (McKercher, 2002:4). Fragmentation is the splintering of audiences into customized and targeted consumer niches for the purposes of commodification (Taras, 2001:61-2). It provides media access to tailored audiences, but not necessarily media choice, as media content (including advertising) is repeated throughout media forms (Taras, 2001:115).

Making mass media institutions more complex does not change their underlying economic imperative; it is an extension of existing economic relations within the latest 
phase in capitalism (Lyon, 1988:58; Garnham, 1992:84). The same issues of media content that arise in mass media ownership-cost-optimization, homogenization of content, marginalization of diversity and dissent, non-controversial viewpoints to attract advertisers, commercialization—are present in media conglomerates. Media globalization replicates the same issues; in fact, Herman and McChesney (1997) contend that the primary effect of globalization itself as the manifestation of global power is "the implementation of the commercial model of communication, its extension to broadcasting and the 'new media,' and its gradual intensification under the force of competition and bottom-line pressures." (Herman \& McChesney, 1997:9).

Changes to mass media systems within the commercial model of communication may give a boost to political ideologies like neo-liberalism that discredit the state and redefine and relocate the public sphere. As Taras (2001:116) speculates, Canada may be unusually susceptible to challenges to its nationhood. As a diverse country in religion, language and culture, and with the political and economic strength of Ontario and other regions, it has few institutions other than communications that bind it together. The dismantling and disaggregating force of new communications forms like fragmentation, along with the homogenizing effects of media content (much of it produced outside the country) may make it more difficult to "maintain significant public spaces, the central public squares that are crucial to the functioning of democracy, in the media society of the future" (116). A more passive, depoliticized citizenry, conditioned by neo-liberal discourses of a bloated, out-of-control state and the promotion of individualism and self-reliance, may find the commercialization of the 2003 Ontario budget speech—what one detractor has called the "budgemercial" (Doucet, 2003:C4)— 
to be democratically acceptable. And if, as this recent example showed, this is not yet the case, is there a point at which "the institutions and agencies of civil society cease to be "vibrant and effective"'? (Golding, 1992:520). Changes to media practice within the commercial model may promote greater reliance on the institutional accommodation that governments provide to media, as evidenced in the televised Ontario budget-a not-to-be-missed media opportunity. A pseudo-event of this nature both reinforces the role of citizen as spectator and consumer and diminishes the role of news worker.

A public service model of communications which produces quality programming in the public interest may seem a welcome antidote, yet such a model as it currently exists is problematic. Support for public broadcasting remains high in Great Britain, the United States and Canada (Bagdikian, 1997:250), despite significant loss of public funding. ${ }^{28}$ In Canada, this has meant a growing reliance (one-fifth of its budget) on advertising and a tendency to compete with other broadcasters for audiences (Hackett et al, 1996:264; Vipond, 2002:138). The need to produce the right audiences for advertising dollars does not serve the public interest, just the interest of the affluent, a preferred audience for their buying power (Ginsberg, 1986:136). Other pressures faced by public broadcasters echo those of private media enterprises, such as loss of audience share and rising production costs, along with the unique pressures faced by a government-funded entity, such as neo-liberal governments inclined to privatization and deregulation (Golding, 1994:9-11).

Ontario, as a province within a nation state, is constrained by federal operations and policies on communication, such as the Broadcasting Act of 1991 and CRTC

\footnotetext{
28 After a series of cutbacks in the 1990 s, the CBC's allocation from the federal government was $\$ 750$ million, about one-half of its budget in the 1980s (Vipond, 2000:139).
} 
decisions, over which it has no jurisdiction. $\mathrm{CBC}$ radio and television is thus broadcast throughout Ontario, along with private broadcasters, including the one-time Ontarioonly Global television. The province at one time owned a radio station, $\mathrm{CJRT},{ }^{29}$ and continues to own TVOntario, which restructured its operations when its government allocation was cut back. Under the Conservative government, TVO was not privatized as promised in the 1995 Common Sense Revolution campaign document, due to a strong campaign launched by TVO's unions to protect it as a publicly-owned station (Kozolanka, 2001:56-9). ${ }^{30}$ The Ontario government subsequently re-focussed TVO's mandate, "enhancing the emphasis on partnerships with the private sector (60). TVO's reporting relationship was switched from the culture ministry to the Ministry of Education and Training, "which emphasized the link to [the government's] newly revised school curricula" (60). As the TVO example shows, when the Ontario government does have jurisdiction over cultural industries, it chooses commercial options-unless political conditions encourage it to act strategically rather than ideologically. In addition, the linkage between the new TVO and the province's school curricula raises questions about the politicization of the legitimating institution of public education.

In the Ontario media environment, however, TVO is more symbolic than influential. CanWest Global has a strong television presence and has demonstrated its political influence over media content in its editorial decisions. Radio ownership in Ontario as of 2002 is still held mostly by three corporations (CHUM, Corus and

29 CJRT, a station with a multicultural focus, lost its provincial allocation completely to the first widespread budget cuts in Ontario in 1992.

${ }_{30}$ The TVO example will be expanded on in chapter 5 as an instance of the limits to hegemonic struggle. 
Standard Broadcasting). These media corporations also broadcast the political talk radio shows that have a conservatizing influence—-the Rush Limbaugh effect—on their audience (Barker \& Knight, 2000:168; Bagdikian, 1997:xxix).

\section{Conclusion: Political Communication and Consent}

Communication plays a strategic role in the selling of neo-liberalism. Traditionally, political communication, the triangulation of government, media and public sphere, is narrowly confined to policy studies and does not allow for the complexities and breadth of a hegemonic regime change such as occurred in Ontario in 1995 and in other jurisdictions where neo-liberal governments have come to power. Hegemonic communication, on the other hand, changes the parameters of political communication in order to include the terrain of struggle that comprises an emergent hegemony. In the often quoted words of Gramsci, this struggle takes place at a transitional time of crisis of authority when "the old is dying and the new cannot be born" (Gramsci, 1971:276). This is a crucial time for an emergent hegemony, in which the "armour of coercion" (263) that surrounds the state may be unusually porous and transparent.

This chapter examined the important elements in the restructuring agenda of the neo-liberal government in Ontario. The dichotomy between the "free market" and the "strong state"' (Gamble, 1993) is played out here as elsewhere where neo-liberalism encounters the state, with the centralizing tendencies of the Ontario government creating a more powerful, centripetal state that is required to maintain and advance hegemony, while public service downsizing moves public functions into the private sector. Communications operations within government have echoed this pattern, 
centralizing legitimating functions while downsizing and relying on private professional public relations and other consultants to provide expertise in marketing government policies.

The Ontario government changed how information flow is structured and managed. Changes to the Freedom of Information and Privacy Act make it more difficult to access government information. Heavy reliance on public relations and advertising have changed how the government communicates with citizens, with huge budgets devoted to promoting the government's policies, rather than the traditional use of government advertising to promote programs. Changes to the Election Finances Act have allowed political parties, such as the governing Conservatives, that can amass large corporate donations, clearly benefiting from the changes. Changes to how legislative business is conducted demonstrate a more restrictive view of government consultations with citizens.

The government has also approached communications management more aggressively, using the spectre of economic crisis to launch communications offensives that supercede traditional, more leisurely and more inclusive legislative and policy paths. The government also frequently bypasses normal channels of consultations to provide unmediated but (costly to taxpayers) information on government activities and policies directly to Ontario citizens.

This chapter also examined how restructuring and government practices of rule have helped to redefine citizenship and the public sphere. The Ontario government's politics of exclusion, which marginalizes different populations such as social assistance recipients, has divided citizens into the 'deserving' and the 'undeserving. By basing 
much of its interaction with Ontario citizens on their role as taxpayers, the government has further divided citizens into 'consumers' and 'non-consumers.' It uses the strategy of strategic alliances to formulate and reformulate groups of citizens and interests as needed to provide support (consent) for policies and initiatives, rather than the ongoing and stable negotiations with sectors that characterized the old corporatist consensus. In contrast to the government's individualizing policies, citizens organized into the 'special interest' groups rejected by the government are seeking renewed inclusion in the polity through collective action against the government.

Against citizen resistance to its policies, the Ontario government has made use of the instruments of legitimation available to government in order to strengthen its hegemony. Communications technologies that enable direct mail and data bases, pioneered by the New Right, have changed how citizens are mobilized, as has the increasing use of public opinion research as a tool that replaces consultation with citizens. Elite advice from the initial hegemonic bloc (think tanks, lobbying groups and international institutional connections) that promoted neo-liberalism in Canada continues to guide this government, as it did for the Conservatives before they came to power in 1995. Powerful neo-liberal discourses of debt crisis, consumer choice and moral discipline combine to support an authoritarian populism that naturalizes the new common sense of neo-liberalism.

Changes to media practices and media systems have also been useful to neoliberal governments that promote the market and privatized communications. The ethos of objectivity continues to privilege dominant interpretations of social reality and mask the exclusion or marginalization of non-dominant views. Although the media are a field 
of continual conflict in the struggle for legitimacy, their conceptual tools of framing and agenda-setting, along with primary definition and accredited access for preferred sources, shape media content in ways that promote homogeneity and harmony of views instead of controversy, which may cost valuable advertising revenues. Mass media institutions are being transformed into corporate conglomerates that are oriented towards profit, rather than the public interest. Their economic logic values bottom-line business values that result in streamlined news making operations and increasing reliance on the institutional accommodation provided by government. The public service model of broadcasting in North America and Europe, intended to operate in the public interest, has faced financial pressures (mostly from neo-liberal governments) that move it closer to a commercial model.

The post-war Keynesian compromise was a period of "deep integration of economic, social and political life that was followed by a period of economic and social uncertainty" (Kelsey, 1999:7). Trends that were symptomatic of a breakdown in social cohesion across Western industrialized nations include: voter apathy (McCormick, 1989:9), low voter turnout (Yankelovitch, 1991:3; Taras, 2001:39), cynicism about politicians and politics (Taras, 2001:39), lack of trust in social and political institutions (Wright, 2003), decline in membership in service and religious institutions (Taras, 2001:39) and decline in party and class identification (Dunleavy \& Husbands, 1985; Clarke et al, 1996). The new paradigm of neo-liberalism did not initiate or arrest these trends, however, they have continued. One new trend in this "inattentive public" (McCormick, 1989:8) is the increasing homogeneity of values across these countries 
over the last 20 years concurrent with the rise of neo-liberalism and the emergence or convergence of a common 'international' culture (Taras, 2001:87-8).

The economic and market focus of neo-liberalism as experienced in Ontario has worked to disengage the Keynesian integration by its tendency to "assign everything a commercial value, and reduce all aspects of society to economics" (Jesson et al, 1988:118-119). Citizens as well are valued as consumers or marginalized or disciplined by their social status (Hermer \& Mosher, 2002:13). Rather than assigned membership and incorporated into society, the excluded are 'managed' through 'law and order' solutions to social problems (Parkland, 2000:10). This privileging of the economic over the social produces confirms the belief, critiques by Hall (1988), that "if you can only get hold of the economy, you can move the rest of life" (170) and in so doing creates "a major conflict between equity and efficiency" (Jesson, 1988:18).

The Ontario government appears to choose the 'thin' democracy of professionalized public relations and communications offensives over the consultative approach of 'deep,' participatory democracy, which is more sustainable over time. It is supported by media systems and practices that legitimate dominant values and messages. Thus, the government faces continued democratic pressures from challenges in the form of alternative and oppositional social movements, a reminder that, in Hall's words, hegemony is not a "state of grace which is installed forever" (1988:170). Instead, the Ontario government, like all social groups attempting to establish a new hegemony, has to work to "sustain supremacy by exercising intellectual and moral leadership based on hegemonic consent" (McBride, 1992:21). 
Pieszka and Schlesinger's (2002:200) question-“can the public sphere be shaped in the interests of the powerful?"-must be seen in the light of the struggle for meaning and the right to shape society. Under neo-liberal governments, which espouse market freedom, "the market is created and directed by powerful groups who get to exercise greater influence on their own behalf' (Jesson et al, 1988:119). This chapter has demonstrated a construction of neo-liberalism in Ontario that is compatible with the legitimating influences of a government rooted in the market ideology, and the next chapter will examine this construction in practice through three cases in which the Ontario government, supported by communication and media, sought to consolidate and maintain its hegemonic neo-liberal project in the face of considerable public resistance. Chapter 5 will continue the discussion by addressing the limits of ideology in an instance where the Ontario government failed to construct consent. 


\section{CHAPTER 4: CONSTRUCTING AND COMMUNICATING NEO-LIBERALISM IN ONTARIO: THE CASE STUDIES I}

\section{Introduction}

The experience of Ontario with neo-liberalism provides a good example of the specific hegemonic communications practices, such as the crisis construction and communications offensives, that have been transferred from neo-liberal, hegemonic projects in other jurisdictions. To these, as with every nation-specific and historyspecific manifestation of neo-liberalism, Ontario neo-liberalism adds its own blueprint. More broadly, it is an example of Gramsci's theory of hegemony in action, starting with the war of position previously waged by the Progressive Conservatives prior to taking power, undertaking a "gradual, sophisticated strategy" (Ransome, 1992:27) that included a pre-campaign internal restructuring of the party, formulation and release of a comprehensive party platform and a strategy during the election campaign itself. As we shall see, however, once in power, the Conservatives did not build on and expand this organic economic-corporate foundation in their internal party structure, but shifted away from it to a form of passive revolution, which occurs "whenever relatively farreaching modifications are made to a country's social and economic structure from above, through the agency of the state, and without relying on the active participation of the people" (Simon, 1982:24-25).

While the preceding chapter of this thesis examined how neo-liberal governments, and this neo-liberal government in particular, work to legitimate and construct consent, this chapter examines the practices used in specific case studies. 
These case studies will attempt to amplify and make visible the "messy actualities" of a specific neo-liberal project and its "historically contingent and internally contradictory aspects, rather than its coherence" (Larner, 2000:14-15). This 'on the ground' approach will help to reveal the "contradictions, complexities and inconsistencies" of this (as with other) neo-liberal projects, as well as the hegemonic communications that support them (16). It will also stress that emerging political projects are

always in competition with one another, producing unintended outcomes and unexpected alignments. Moreover, [it] is never a complete rupture with what has gone before, but rather is part of an ongoing process involving the recomposition of political rationalities, programmes and identities" (14).

This approach must therefore go beyond authoritative accounts and discourses (and the tensions within them) and examine contested and competing alternative and oppositional accounts. This is congruent with the agency that Gramsci assigns to social actors in active hegemonic struggle. It also demonstrates how neo-liberalism, as with any hegemonic project, is not monolithic or undefeatable and, in reaction to the forcefulness in the implementation of the neo-liberal project, how easy it can be to give it undeserved credence, thus preventing effective analysis and action (Williams, 1983:9).

The case studies also demonstrate how times of transition to a new political paradigm or system are critical moments that can reveal more openly the coercive power of the state in attempting to maintain legitimacy. Even in a transitional situation where a government is anti-interventionist, it uses the mechanisms of state legitimacy in order to retain order and power. State strategies that coerce in the effort to maintain legitimacy_-increasingly elitist politics, erosion of formal parliamentary democracy, 
destruction of trade unions, stratification of the population, fomenting of internal divisions within society" (Kelsey, 1994:185)-can be undertaken at the same time as a government is in the process of restructuring the very institutions and practices from which legitimacy can be derived. This is the contradictory situation in which the new Ontario government, citizens and the media found themselves in 1995.

Using empirical and qualitative evidence as support, the case studies in this and the following chapter will examine the "conditions under which a major ideological offensive via the media in a centralized capitalist state comes to grief or is significantly deflected" (Golding, 1991:514)—or, alternatively, wins. One aspect of this, as in Golding (1991) and Deacon and Golding $(1991,1994)$, is to "supplant a simplistic theory of strong or weak media effects with a more elaborate comprehension of the media-society complex" (Golding, 1991:520). As in Gramsci (1971), this approach accepts the importance of civil society as the sphere of social relations in which and through which struggles take place and public consent is won.

In addition to the three case studies that demonstrate varying levels of success for government ideological offensives, the Ontario government faced strategic decisions as it implemented the Common Sense Revolution. With its massive restructuring agenda, decisions involved choosing priorities from the CSR that could be implemented quickly while minimizing the potential for failures. The case studies here demonstrate the success of the government in face of continuing and mounting resistance, while the next chapter will examine an example of how an ideological offensive in a key area, privatization, can be deflected. 
While each case study has its own specificity, anchored in a particular moment in the development and consolidation of the new hegemony, similarities among the cases as well as their differences will be probed. The cases provide terrain for developing an understanding of changing social relations in Ontario that relate to class interests, definitions of democracy, locations of power and the nature of consent. They also demonstrate how changing relations of communications systems and practices interrelated with the growth and sophistication in government communications have an impact on ideological offensives.

Two cases, one in Great Britain and the other in New Zealand, will first illustrate both the success and failure of such offensives. In 1986, the Conservative government of Margaret Thatcher in Great Britain announced a reform of local government finance, called the community charge but known as the "poll tax". The government positioned the refigured charge, which also centralized levying ability, as “good for local democracy" (Deacon \& Golding, 1991:295). Significantly, local government also held a strong Labour base of support which the poll tax would minimize (Edgell \& Duke 1991:86). ${ }^{1}$ As with many of the policy initiatives conducted by the Thatcher governments, the poll tax was supported by "a substantial public relations exercise to explain and promote the new system" (Deacon \& Golding, 1991:295). The public relations campaign included a direct campaign to citizens through a series of booklets, leaflets and ads, and an indirect campaign through the media. The cost of the ads and one leaflet came to 98 million pounds (\$11.1 million

1 Edgell and Duke estimate that the Conservative government created more than 60 bills affecting (Labour-dominated) local governments through cuts in spending and centralizing control between 1979 and $1989(86)$. 
current Canadian). Despite these campaigns of persuasion, partisan opposition, public resistance and negative media reports were substantial and the government was forced to withdraw the poll tax legislation in 1990. Deacon and Golding's (311-2) analysis concluded that the government showed a lack of political and ideological cohesion and that an organized and resourced opposition influenced local media frames, consistent with Negrine (1996:180) that "[p]ublic protest aided and abetted by a doubting media can have an impact". It also showed that media conglomeration and state centralization "create the conditions for an unprecedented concentration of power over political communication" (Deacon \& Golding, 1991:312). Although the Thatcher government launched an ideological offensive to promote the initiative, with the power and resources of the legitimating functions of government behind it, 'ideology failed', as Deacon and Golding put it. ${ }^{2}$

Scott (1997) compares the poll tax defeat with a successful initiative of the New Zealand government, the Employment Contracts Act (ECA), a bill that reduced the role of the state in collective bargaining. Scott notes that a determining factor in the success of the ECA campaign was the use of the blitzkrieg communications offensive that was a common strategy in neo-liberal politics in New Zealand. Other important factors included: elite and government consensus; extensive use of institutional accommodation and primary definition (these concepts were discussed in the previous chapter); division in partisan opposition ranks; the truncated time-frame for the bill to pass through the legislative cycle (six months, compared to six years for the poll tax); and the low-key strategy of the government in not promoting the Act, one among many government

2 The other consequence of the poll tax debacle was the Conservative Party's successful removal of the Prime Minister from that office because of her refusal to back down (Bruce, 1992:86). 
initiatives at the time, until opposition activity grew (Scott, 1997:196-7). It also helped that the media framed the main opposition - the trade unions - and the government as "political game-playing" (195) and relied strongly on authoritative sources and press association news copy (Scott, 1997:195). In addition, as in Great Britain and elsewhere, changing media systems reinforced the increasing power of government communications to shape political realities.

The lessons from these two jurisdictions, with their different outcomes, were not lost on subsequent neo-liberal governments, particularly when the architects of New Zealand neo-liberalism, with the help of the Fraser Institute, promoted their successes in Canada (Kelsey, 1995:34; Dobbin, 1998:264-5).

\section{Ontario, Neo-Liberalism and the Global Economy}

The regional and provincial levels of government are "where much of Canada's political life takes place" (Hackett et al, 1996:262). Ontario, in particular, with its 11.6 million people is home to nearly $38 \%$ of Canada's population of 30.6 million (Ibbitson, 1997:243). At 7 million people, Toronto is Canada's largest city, its outskirts extending from Oshawa in the east to Burlington in the west (243).

In recent years, globalization and free trade agreements have put "intense pressure" on the province's industrial manufacturing base, creating a dilemma also felt in other industrialized countries with similar pressures: "how to sustain post-war provincial living standards and income distribution in the conditions of the new global competition" (Bradford, 1998:544). On the positive side for the province, Toronto is the country's centre for international finance and business, its "undisputed financial and 
commercial services centre" (Todd, 1995:196). Forty-two of 56 foreign banks, half of Canada's largest insurers and half of the largest Canadian corporations have head offices in the city. It is also the home of Canada's largest stock exchange, and financial and money market activities are concentrated there: "In essence, Canadian capital has organized itself around Toronto and sees little reason to change" (198). Toronto is also the hub for other massive economic activity that has linkages beyond the finance sector; for instance, cultural industries alone contributed $\$ 8.4$ billion to the GDP of the greater Toronto area in 1994 (Ross \& Renzetti, 1997:C1).

At the same time, Kipfer (1988:153) points out that the political economy of Toronto is changing in other ways. The middle-class is employed in the service sector, while increasing non-European immigration is concentrated in low-income marginal sweat-shop employment. Urban middle-class communities are 'gentrifying', while new immigrants are settling in the suburbs. These trends and divides are "exacerbated by depressionary circumstances and austerity politics" (173). As will become evident in the Megacity debates, Citizens for Local Democracy, which formed to 'defend' democracy against the Harris government's proposed amalgamation of Toronto, was defending the 'old' Toronto—a "progressive, urban, middle-class regime that evolved over the years through the work of people like those active in C4LD. It was a regime prioritizing universal health care and quality education, public services and redistribution" (Boudreau, 2000:116). It was also focused on centrality and "opposition to suburban life" (116), positioning the two Torontos as polarized opposites, "preclude[ing] the possibility of viewing the region as a whole, in all its diversity" (116). 
Thus Toronto is strategic terrain through which Ontario is linked to the global economy as well as the seat of provincial government in a dialectical relationshiphave/have not, centre/periphery, urban/suburban/exurban, working/middle/upper middle class, old ('white')/new ('black'), liberal/conservative-within itself and with the rest of the province. In addition, because of its connectedness to the relations of international capital, the historic bloc that came to government in Ontario in 1995 was a composite of interests that originated, not just outside the province, but outside the country. ${ }^{3}$

The election platform document of the Progressive Conservative Party, the Common Sense Revolution (CSR), signalled significant change in the operations of government that was predicated on the claim of a crisis in the polity that needed to be addressed. ${ }^{4}$ Within months of its coming to power, the Ontario government acted on the platform and

negated much of what previous governments had accomplished, especially the New Democrats in their five years in office, but they had proceeded in a manner far removed from the style of government provided by previous Tory governments. Ontario, noted for the generally moderate and measured character of its political life, suddenly echoed with right-wing rhetoric; a province that for most of its history had avoided political extremes now bristled with heated political debate and, seemingly, had replaced Alberta as the leading voice of neo-conservatism (Woolstencroft, 1997b:385-386).

\footnotetext{
3 More recently, a sign of Ontario's continued vision and positioning of the province in the global economy is the creation of a new ministry. As of April 15, 2002, James Flaherty became the first Minister of Enterprise, Opportunity and Innovation. As described on the Ontario government web site, "this newly created ministry brings together economic development, trade, innovation, science and technology into a single Ministry. Its mandate is to secure Ontario's position on the leading edge of the global economy by advancing innovation and excellence in all industries throughout the province and promoting Ontario's economic development achievements worldwide" (www.ontariocanada.com/ontcan/en/home.jsp). At least one of the functions of the new ministrytrade-is formerly a federal government responsibility only.

4 Walkom (1997:406-408) has shown that the two major claims implicit in the CSR-that Ontario was worse off, particularly in the areas of spending and taxation [and] that it had slipped behind other provinces and states"-were not true.
} 
Following the advice of the Alberta government to move quickly, and also to keep the opposition off-balance, the government began by making extensive cuts to the public sector and "shoehorned more than a generation's worth of reforms and restructuring into two and a half years of unremitting action" (Ibbitson, 2001:148). The "remaking of common sense", as Hall (1988:8) said about Thatcherism, was now in its implementation phase.

\section{Introduction to the Case Studies}

The three case studies undertaken in this thesis are situated within the first half of the government's first mandate, between June 1995 and December 1997. As a period of transition between the old order of consensual, brokerage politics and neo-liberalism, the case studies are well-suited to demonstrate the conditions under which the new paradigm took hold in Ontario. As delineated in chapter 3, the new government was different in substance and style from traditional Ontario governments. The processes of legitimation used by the new government relied heavily on the hegemonic role played by communications in helping to structure understanding and win popular consent (Knight, 1996:96). 'Mapping' (100) the media coverage and public opinion of the three cases will demonstrate: the use, extent and impact of primary definition, preferred readings and institutional access; the connection between phases of the cases and the formal policy cycle; the extent of challenges to the emerging paradigm; and the agenda setting and agenda-building force of the government. As will become clear, this was a period of dynamic interaction and contestation for power among the actors that constitute the main spheres of influence in political communication (or, rather, 
hegemonic communication, as was put forward in chapter 3): state/government, the public and media/communication. In particular, the analysis will go beyond dominant actors to focus on the communications strategies of alternative and oppositional actors in order to give a more complete picture of the hegemonic struggle on the nascent terrain of neo-liberalism in the province.

The media mapping concentrates on the three main Toronto newspapers, The Globe and Mail, The Toronto Star and The Toronto Sun. The choice to focus only on these Toronto-based media outlets reflects the importance of the greater Toronto area to the Conservative neo-liberal project, by virtue of population concentration, geographic proximity to international centres of power, the concentration of the national financial and business apparatus in the city and the importance of Toronto electorally. The exclusion of other media, particularly those based beyond Toronto, places a limitation on the conclusions that can be drawn from this mapping exercise, however, the chosen focus should be seen to reflect the priorities of the government and its actions. The analysis also refers to the main business media, national television broadcasts and media reports, both from other Ontario localities and Canada-wide, as necessary. As the case studies unfold, the communication efforts of the challenger groups will be shown to include efforts such as newsletters, e-mail information, speeches and efforts that contribute alternative and oppositional viewpoints to the media sphere.

The three Toronto-based newspapers have an added advantage for analysts. In these days of media concentration and conglomeration, Toronto constitutes one of the very few media markets in Canada where three newspapers with different ownership and focus co-exist. They thus can provide a comparison of approaches to the business 
of news. At the time of these case studies, Thomson Corp. wholly owned The Globe and Mail, considered Canada's newspaper of record, the authoritative account of the Canadian polity: "Long considered the voice of the Canadian establishment, the Globe's positions are reliably conservative" (Taras, 2001:217). Its detractors use it to establish the issues against which they will react. Although it covers local issues, the Globe is not known for extensive coverage of Toronto-based news (CHC, 2003:3). Torstar Corporation owned The Toronto Star, along with several other Ontario dailies. The Star is acknowledged as the print media outlet that is heavily focused on Toronto news. Its reputation in the 1970s and 1980s for more progressive views and coverage has declined in recent years. Sun Media Corporation owned The Toronto Sun and five other dailies (3). ${ }^{5}$ The Sun is a tabloid in which opinion, photographs and sports coverage are prominent, but that eschews features and other in-depth coverage. Taras (2001:217) writes that the Sun and its other like-named newspapers in different cities in Canada are known for "their unabashed civic boosterism, their appeal to male working class values, and their 'little guy on the street or in the subway car' suspicion of Ottawa politicians".

It is acknowledged that, regardless of the importance of Toronto to these case studies, the approach is nonetheless Toronto-centric and undoubtedly misses the perspectives that may have emerged in regional media coverage. In addition, by not including analysis of tapes of television broadcasting, the images in that coverage were not part of this analysis.

${ }^{5}$ Currently the three newspapers are owned as follows: Through its ownership of Bell GlobeMedia, Bell Canada Enterprises controls $70 \%$ of The Globe \& Mail, while Thomson Corp. retains ownership of 30\%; Torstar still owns The Toronto Star; and Quebecor Inc., through its ownership of SunMedia Corporation, owns The Toronto Sun (CBPF, 2002). 
The form of the media analysis will follow Hansen and Murdock (1985), Golding (1990, 1991), Deacon and Golding (1991, 1994) and Knight (1998). Using riots in cities in the United Kingdom in 1981 as a case study, Hansen and Murdock (1985) examine how the right-wing discourse of authoritarian populism set the terms for popular debate and its reconstruction in the media coverage of the riots. Deacon and Golding $(1991,1994)$ use the poll tax initiative in Great Britain as a case study to demonstrate how ideological initiatives emanating from majority governments can fail and they offer their understanding of the conditions under which this failure can take place. Knight (1998) compares the media coverage of newspapers in reporting two different pieces of strike-breaking reform legislation, Ontario's Bill 40 in 1992 and Quebec's Bill 45 in 1977 . To the extent possible and relevant, this thesis will replicate these examinations of actors and messages in its case studies.

The media mapping exercise also includes personal interviews with various actors prominent or knowledgeable about the cases, particularly non-authoritarian or challenger actors. The intent of conducting such interviews is to develop a more complete picture of challenger strategies in order to compare their efforts with mainstream media accounts.

The remainder of the chapter is divided into three parts, one for each of the three case studies: the public service strike and the Days of Action; the amalgamation of Toronto and Megaweek; and the Education Quality Improvement Act and the teachers' walkout. The three parts of the chapter are linked by analysis throughout and are followed by a separate chapter that contextualizes resistance within the labour and social justice group-organized Days of Action. The latter chapter also looks at instances 
where the Ontario government was not able to achieve consent for initiatives in its neoliberal hegemonic project. 


\section{Case Study 1: The Public Service Strike and the Days of Action}

\section{Introduction}

The first ever strike by Ontario provincial government employees followed months of upheaval resulting from a quick series of legislative and policy actions undertaken by the new government. These included a total of $\$ 5.5$ billion in reductions in government spending before the end of the fiscal year, including cuts to health, education, social assistance, labour and housing. The strike followed on the heels of two major pieces of legislation that removed labour rights.

Bill 7, the Labour Relations Employment Statutes Law Amendment Act: an Act to restore Balance and Stability to Labour Relations and to promote Economic Prosperity, was introduced in the Ontario legislature on October 4, 1995 (Legislative Assembly of Ontario web site). Three weeks later, it had passed through all three readings in the House without public hearings. Bill 7 effectively repealed a bill passed by the previous government. The new law was a significant blow to labour: it had provisions to allow replacement workers ('scabs') during strikes, removed successor rights, ${ }^{6}$ made it easier to decertify a union and required a vote before certification (Glasbeek, 1996:A13; Rapaport, 1999:38, 47).

On November 29, 1995, the government introduced Bill 26, the Omnibus Savings and Restructuring Act. Amongst a great many other sections dealing with

6 Successor rights allow a union in a workplace that comes under new management to retain the union and its collective agreement. Under neo-liberal restructuring, which encourages the provision of formerly government services by the private sector, "the abolition of successor rights makes the purchase of government services cheaper" (Glasbeek, 1996:A13) because the private sector purchaser does not have to pay higher unionized wages and benefits. 
Figure 2

\section{Chronology: Ontario Public Employee (OPSEU) Strike}

June 8, 1995

July 6,1995

July 21,1995

July 1995

September 27, 1995

October 4, 1995

November 22, 1995

November 29, 1995

December 11, 1995

December 18, 1995

January 29, 1996

February 4, 1996

February 15, 1996

February 23-24, 1996

February 25, 1996

February 26, 1996

March 18, 1996

March 29, 1996

April 19, 1996

June 24, 1996
Progressive Conservative government is elected in Ontario

Minister of Education John Snobelen tells his ministry that he will invent a crisis in education in order to gain public support for overhauling the education system

Government announces $\$ 2$ billion in cuts to social assistance rates and program and social services agency cuts

OPSEU begins strike preparations and conducts first poll of its membership to test attitudes on collective bargaining and a strike

Speech from the Throne as protestors rally outside the legislature

Bill 7, Labour Relations Employment Statutes Law Amendment Act, which rescinds the previous government's labour laws, is introduced

Government unexpectedly applies for conciliation in negotiations with OPSEU, indicating it is moving towards a strike

Bill 26, Omnibus Savings and Restructuring Act, is introduced on the same day as the government's first fiscal and economic statement, which announces an additional $\$ 3.5$ billion in restructuring cuts

London Day of Action

Two weeks of hearings on Bill 26 begin

Three days after hearings end, Bill 26 is passed into law

OPSEU asks the government for its "best offer", ending conciliation

OPSEU takes a successful strike vote on the best offer

Hamilton Days of Action

Premier's Office leak to media that government will bring in replacement workers ('scabs')

55,000 OPSEU members go on strike (a further 12,000 are essential service suppliers)

Ontario Provincial Police actions spark violence at Queen's Park during daily picket on the first day of the spring session of the legislature

OPSEU strike ends

Kitchener-Waterloo Day of Action

Peterborough Day of Action 
different sectors in the 211-page bill, it weakened pension rights and diluted the power of arbitration for those Ontario public sector workers who didn't have the right to strike and who had instead relied on that mechanism to negotiate contracts (Glasbeek, 1996:A13; Rapaport, 1999:39). The Ontario Public Sector Employees Union (OPSEU) had only recently received a limited right to strike under the previous government.

Bill 7 had only targetted labour, and its passage into law was swift and almost unseen, but Bill 26 affected many sectors, centralized powers in the hands of the government over matters that had previously been handled in the legislature and became a catalyst for the growing opposition to the new government. On the same day that Bill 26 was introduced, the government brought down its first economic statement, in which it announced severe reductions in ministry budgets and public sector jobs. This was its second such announcement in five months.

During this time, OPSEU was bargaining with the government for a new contract. It was clear that the government was not interested in bargaining, but instead wanted to force the union to make a decision against a strike quickly so that layoffs could begin and it could meet its expenditure targets (Ibbitson, 1997:158-159). ${ }^{7}$ Given the general history of public sector unionism in Canada (white-collar workers who had a distaste for job actions) and the history of OPSEU itself (it had never been on strike), the government was expecting a quick victory so that it could get on quickly with its agenda (Walkom, 1996:A1; Ibbitson ,1997:149). In addition, the government, which was also the employer, passed Bills 7 and 26 limiting labour rights during bargaining

7 The government applied for conciliation before both sides had finished outlining their positions (Ibbitson, 1997:159). 
(Watson, 1997:139). According to the suggested order of neo-liberal structuring from the Washington Institute for International Economics (Williamson, 1994) and the experiences of other neo-liberal governments analyzed by Savoie (1994) and Schwartz (1997), one of the first neo-liberal government targets is public sector unions. A pared-back public service simultaneously would provide the government with budget savings, the appearance of action and a warning to other 'interest groups'.

Integral to the OPSEU strike was the growing public opposition by various groups, sectors and individuals to the Harris government agenda. In particular, the strategy by organized labour to hold Days of Action in cities around the province contributed to an environment of protest. In all, 11 such actions were held throughout the province over a period of three years. The actions drew crowds of up to 100,000 and closed down to different degrees the day-to-day operations of the city chosen for the action (Turk, 1997). Opposition was broadened beyond labour symbolically when labour began to co-chair each protest day with a member of a local Coalition for Social Justice group. The second Day(s) of Action was held in Hamilton February 24 and 25, 1996 on the weekend before OPSEU went on strike. Thus OPSEU's own mobilization efforts were bolstered by the perception of approval of a broader cross-section of labour and social justice groups (Rapaport, 1999:85). It is possible that OPSEU would not have ended conciliation if it had not believed the strike would take place within a supportive environment, but the union was also facing 13,000 layoffs from the government restructuring and it was strategically difficult to merely accept the government's plan without action (Ibbitson, 1997:177). 
The union negotiating position was mostly related to job security. It wanted the government to reinstate the successor rights removed in Bill 7 (which would ensure continued pay and benefits at the current level), bumping rights (which would delay the inevitable layoffs $)^{8}$ and retraining guarantees $(154,159)$. The union did not ask for a wage increase, although wages were still at 1991 levels (159). The government's offer called for no successor rights, quicker layoffs and reduced government contributions to the union's pension plan.

The turning point in the five-week strike was a violent altercation at Queen's Park on March 18, the opening of the spring session at the legislature, when the Ontario Provincial Police (OPP) riot squad clubbed and pepper sprayed peaceful strikers and other protesters. This was caught on camera and televised across the country. The impetus for the OPP actions was providing an escort for government cabinet ministers and MPPs who wanted to enter Queen's Park. The government, perhaps in realization that "a negative image was being created both at home and abroad of a government unable to manage its own workforce, of a government dominated by labour unrest" (Walkom, 1996:A1) went back to the bargaining table. The strike ended March 31, 1996, after five weeks.

\section{Government Communication Strategy}

The government's strike strategy ${ }^{9}$ was to emphasize the futility of the strike while promoting strike replacement workers in an effort to weaken the strikers' morale and

\footnotetext{
8 Bumping rights are seniority provisions which give employees with longer service who may be laid off the right to replace an employee with less service.

9 The government's strategy has been reconstructed from media reports, interviews and other published accounts of the strike. A request under the Ontario Freedom of Information and Privacy Act was denied,
} 
end the strike quickly (Rapaport, 1999:119). It was focused on meeting its target for expenditure reductions before the end of March (Ibbitson, 1997:159). This was reinforced by a leak from the Premier's Office just before the strike started which showed the government was ready to bring in replacement workers (163). The government's strategy was not to communicate with the union and to limit media access to staged opportunities-institutional accommodation (Tiffen, 1988:33) — which would channel and concentrate the government's messages more directly to the public. A media blackout on bargaining, although not unusual, meant no media coverage to convey information or progress on negotiations to the public, so the public relied for information on the accommodation which emphasized the government's point of view (FitzRandolph, 2002). It also gave prominence to Minister Dave Johnson, an effective spokesperson (Ibbitson, 1997:163), who was "out front" in providing managed soundbites to the media (Rosenberg, 2002).

A prominent tactic in the government strategy was to use the legal system to try to close down the strike. The government filed more than 30 applications at the Ontario Labour Relations Board (OLRB) and 82 court actions during the strike, mostly to declare more OPSEU work as essential services (thereby reducing the number and public visibility of the strikers) and limit the number of picketers and picket locations (Rapaport, 1999:181-3). The OLRB almost always ruled for the union (Ibbitson, 1997:73). A further element in the government's strategy was its 'divide and conquer' tactic. During the strike, the government successfully and quietly negotiated a

due to legislative changes made by the government in its first months in office that excluded from the Act "records relating to labour relations and employment-related matters. The effect of this provision is to deny a right of access to many records related to collective bargaining..." (Roberts, 1999: 447). 
collective agreement with a second, smaller public sector union (Ibbitson, 1997:175; Rapaport, 1999:129), which reinforced its desired image as 'fair and reasonable' (see Table 10). At any point in the strike, the government could have used its majority in the Legislature to order the strikers back to work, but it chose strategically not to use that heavy-handed tool in order to maintain its positioning as reasonable-rather than “desperate and dictatorial" (Girard, 1996:175).

The messages used by the government echoed the findings from its custom polling, conducted by Ipsos-Reid (1996a, 1996b, 1997c). In the three tracking surveys, support for the government's handling of the strike remained constant (between 58\% and $61 \%$ ), which was the major finding in the surveys for the government (Bricker, 2002). In the three polls, the government was able to 'push' responses into support by preceding questions with a preamble characterizing both its and the union's position. In this way, it moved support for its position from $66 \%$ to $84 \%$ (although not in itself a credible way to ask a question, it serves to identify what will move opinion, therefore contributing to the message-set used by the government). Despite the leading preamble, which tells respondents that the union's position will be bad for the economy, $52 \%$ still say the government's offer is just "a public relations tool" (Ipsos-Reid, 1996a:108).

The government's ideological message to the strikers and the public was encapsulated in the remarks of Premier Harris to a party policy convention prior to the strike during the Days of Action in Hamilton: "We promised to deliver the Common Sense Revolution. No special-interest group or lobby will stop us. No union-leader-led demonstration will deter us" (Ibbitson, 1997:214). 


\section{Challenger Communication Strategy}

The union's main strategy developed from a workshop in January 1996 that began the planning process to develop ideas and shape a communications and advertising plan for the upcoming strike (OPSEU, 1996b), although the first work on strategizing started right after the June 1995 election (Rooney, 2002). The strategy was based on two core assumptions. First, the union assumed Ontarians would want to give the new government a chance to do the job it was elected to do, so it needed to avoid relaying a 'who's running the province' message. Second, the union realized that OPSEU members did not have a public face. Unlike most unions, OPSEU members held a variety of different positions spread across different sectors and job sites and were not easily recognized as either union members or OPSEU members. The union's strategy was to make the services performed by OPSEU more visible and make its approach more reasonable than the government's (Rooney, 2002).

The union's pre-strike focus was to build credibility with its members and the public. Custom polling conducted in summer and fall of 1995 showed slight increases in support as the members received information from union headquarters, but the highest indicator of support came after "the fear factor had set in", as members realized they were being targeted for layoffs (Rooney, 2002; Rapaport, 1999:89, 223-4). The polling also helped to refine the strategy; for instance, as a result of the polling, 12,000 Toronto members were phoned to shore up support. The union also organized administratively and politically to be able to handle the fast pace of a strike, forming seven coordinating groups to match its seven regions (Rapaport, 1999:110). The union used the "newsletter culture" it had developed over the years to reach members and, 
through them, the public (56; FitzRandolph, 2002). It also built morale by encouraging its members to participate in the London and Hamilton Days of Action in order to feel part of a broader anti-Harris opposition and feed into its "culture of resistance" (Rapaport, 1999:56). By the time OPSEU members went on strike, there was a growing sense that they were acting on behalf of Ontarians with a large element of public opinion behind them.

Both the government and union strategies concentrated their efforts on the picket lines themselves. The government, through its injunction strategy, attempted to minimize the pickets' numbers and venues, while the union saw the pickets as public space_-as small "communities" (FitzRandolph, 2002) — and did everything it could do maintain them (Rapaport, 1999:116-7). To the union, picket lines constituted visible communities of opposition supported by the broader communities (117).

The union strategy also planned to use government mistakes, which the union felt were inevitable for a government that was both "new and ideological" (Rooney, 2002). The union counts as one government mistake "the huge amount of energy" that Minister Johnson devoted to union members by aiming his daily scrums at them, often in a 'divide and conquer' strategy of revealing the increasing total of strikers who crossed the picket lines and returned to work. ${ }^{10}$ This had the contrary effect of strengthening the union's resolve (Rooney, 2002). In the union's view, the altercation at Queen's Park was the government's second mistake. Rooney says the cross-country media coverage of strikers being clubbed by the OPP had a huge impact and reinforced

10 At the time, there were about 67,000 OPSEU members, of whom 12,000 were considered essential service workers. Of the 50,000 on strike, about 30,000 members walked the picket lines, 20,000 members stayed home and 6,000 either stayed on the job or crossed the picket lines and returned to work during the strike (Rapaport, 1999:102, 163). 
the message that the union was acting reasonably. ${ }^{11}$ (The government's custom polling showed, in fact, that opinion was split on the cause of the violence (Ipsos-Reid, 1996c:47). ${ }^{12}$

The union's messages were developed in the acknowledgement that they "needed to be adapted to fit the neo-liberal framework while challenging it" (Rooney, 2002). Radio ads prepared for the union used the voices of OPSEU members to deliver the message: "We know the deficit is a problem. We know that changes have to be made. We know our services need to be more effective. We want to work with the government to find solutions now to protect the services everyone counts on. For information on the public service workers' 30 -point plan to cut costs, please call 1800..." (OPSEU, 1996c). The emphasis was on the 'alternative' message of fairness, not as opposing the entire government agenda, but instead "tapping into... nascent public doubts" about where the new government was heading (Smith, 1996:B1). This framed the messaging and opposing the style and direction of the government's actions, but not their substance.

\section{Media Coverage}

The media initially showed little interest in the impending strike until it actually started (Rapaport, 1999:107). The strike was covered as a political rather than a labour story in the media (FitzRandolph, 2002) and stories appeared prominently on news pages.

\footnotetext{
11 A later inquiry into the violence apportioned blame to all parties, but primarily to the Speaker of the legislature, Conservative Al McLean, who had ordered in the OPP, and the Queen's Park OPP unit itself (Ibbitson, 1997:173).

12 The wording of the question twice mentioned "picket-line violence" and "violence", and two of the four responses provided targeted the union as responsible ( $32 \%$ and $23 \%$ agreement), one the government $(10 \%)$ and one the police (24\%). No connection was made in the question to a possible linkage between the police and the government.
} 
Media coverage appeared consistently across the three main Toronto newspapers which together provided 338 items in the 33 days that the strike lasted. Media interest in the strike reinforced the union's morale (Rapaport, 1999:117).

Once the strike began, coverage was set within the traditional frame of labour unrest as self-interested, "motivated by a narrow-minded concern for [its] own sectional interest, while the government is presented as being motivated, in a non-sectarian way, by concern for the "national interest"' (Morley, 1976:250-251). A second prominent frame in media coverage of strikes is disruption and disorder. For the state, which is entrusted with keeping public order, there is a general assumption of a shared understanding of what is socially normal (non-disruptive and in the shared societal interest) and what is socially harmful (disruptive and not in the shared interest of society). For the media, disruption and conflict are newsworthy elements that result in coverage that stresses potentially harmful impacts to society. When applied to public sector strikes, this frame "stresses inconvenience to the public-as-consumer, exacerbated by the monopolistic character of many state services which offends the democratic ideology of the marketplace by denying alternative sources of supply" (Knight, 1982:63). The disruption and disorder frame extends to militancy and unreasonableness, which, in effect, characterizes any strike activity, since a strike in itself challenges social acceptability: “One of the most characteristic of workers' or unions' actions as presented in the news is to go on strike, and the consequences of strikes are almost always said to be negative" (Hartmann, 1975/76:17). In addition, most coverage of labour in the media is concentrated on strike activity (Hackett, 1983:11), despite the fact that the vast majority of contract negotiations end without 
such action, giving a skewed impression of labour. Unions undergoing strike activity thus face a public and media that draw on "pre-established cultural 'maps of meaning"" (Morley, 1976:247) that present a negative depiction of labour. As OPSEU Communications Director Frank Rooney (2002) said, "we knew our credibility would go down on Day 1 of the strike".

Because of the pre-established roles set out for the different actors in a labour strike, it is somewhat easier to notice when there are deviations. In the case of media coverage related to this public sector strike, it generally followed the traditional frames of self-interest and public inconvenience, while the 'riot' at Queen's Park afforded an opportunity to elaborate on 'picket-line violence', with its inference of union member causality. The Globe and Mail began its front-page story on the Queen's Park incident with "a phalanx of riot police clubbed and pushed its way through a crowd of striking civil servants yesterday to clear a path for cabinet ministers and Progressive Conservative MPPs to get into the Ontario legislature" (Mittelstaedt \& Rusk, 1996:A1) and continued with descriptions of "helmeted" members of the "riot" squad "swinging batons" and "shoving strikers out of the way". Government ministers "looked terrified" and one MPP indicated the police had instructed them to "run like heck". Deep in the lengthy story, it was noted that "[t]he legislature has always been the scene of noisy and boisterous demonstrations, but since the Tories were elected the demonstrations have had a violent undercurrent, one that is often heightened by a large police presence". A later editorial in the Globe (1996:A14) noted the "organized violence and intimidation", which it attributed to "big labour" and linked to previous, unrelated violent protests at Queen's Park. The Toronto Star's account focused on the partisan opposition's demand 
for a public inquiry into the "excessive and extreme force used by baton-swinging" police to "quell a protest by striking civil servants". Premier Harris was quoted as saying that, instead of blaming the Speaker or the police, that "it was time to start behaving... like adults". The Star also published a short story on an inside page about the striker who was hospitalized after being clubbed by a police baton. The Sun's account of the altercation focused on the larger than usual picket line, bolstered by other union members for the opening of the legislature. It quoted Solicitor-General Bob Runciman's accusation that OPSEU "brought in people who want to provoke and instigate violence" and ended its story with its only quote from OPSEU - Casselman at a later rally saying "we are your worst nightmare" (Magnish \& Ganley, 1996:2). All three Toronto newspapers treated the altercation as a parliamentary story, although one that was oddly mixed with violence and fear that is not usually associated with such accounts and would therefore have shock value. Although the Globe concentrated on the violence and fear engendered in the incident itself, thus emphasizing the affront to parliament, the Star and the Sun gave substantial play to the partisan opposition. The Star, with its side-bar on the injured striker, provided the only sustained report that used the union's 'side' of the story. ${ }^{13}$

Given the socially constructed antagonistic nature of a strike, it follows that media coverage would reflect polarized points of view from the two main actors, and this is indeed the case with this coverage. As Table 3 shows, government and union actors in leadership roles together were referenced in $51.6 \%$ of the media coverage in

13 This is one incident that would have provided powerful images in television coverage, which is outside the purview of this analysis; Ibbitson (1997:171), for instance, makes mention of the sight of MPPs stepping over "the recumbent body" of "an injured striker" in order to get into the legislature. Rapaport (1999:9) called the "forceful behaviour of striking civil servants and the violent response" by the police the strike's "lasting images". 
the Globe, $42.9 \%$ in the Star and $49.4 \%$ in the Sun. All government and union actors together were referenced in $67.0 \%$ of coverage in the Globe, $76.3 \%$ in the Star and $72.0 \%$ in the Sun. Other actors, whether alternative or oppositional (Williams 1977), did not enter into the coverage in a substantive way.

Table 4 shows the proportional presence of actors, that is, when all references to an actor in a media report are counted instead of only the first reference to that actor that we saw in Table 3 . Here the over-access and influence of the two principal actor

Table 3

\section{Political Actors in Mainstream Print Media Coverage on the OPSEU Strike (February 25-March 31, 1996)}

by media outlet by percentage

\begin{tabular}{llll}
\hline $\begin{array}{l}\text { Actors } \\
\left(1^{\text {st }} \text { reference only }\right)\end{array}$ & Globe \& Mail Toronto Star & Toronto Sun \\
\hline
\end{tabular}

\footnotetext{
Party Political Actors

Provincial government

Premier \& lead ministers Other Conservative politicians

Provincial political opposition

Provincial Speaker

\author{
Non-Party Political Actors \\ Unions \\ Union leadership \\ Other unions \\ Individual members \\ Public actors \& groups \\ Challengers \\ Supporters \\ Academics \& experts \\ Private sector/business \\ Lawyers/courts \\ Police \\ General public \\ Misc.
}

$\begin{array}{rrr}30.3 & 26.5 & 29.7 \\ 1.4 & 2.7 & 0.8 \\ 2 & 6.9 & 1.3 \\ 1.8 & 0.9 & 0.4\end{array}$

19.3
2.3
7.8

0.0
0.0
8.7
5.1
6.9
2.3
0.0
10.1

16.4

3.9

19.0

19.7

2.3

7.8

0.0

0.0

16.3

Figures relate to news items (only) which focused on the OPSEU strike.

Figures refer to the first reference to the actor in the news item. 
sets is lessened slightly (at $66.1 \%$ ), while police actors and individual union members gain in prominence. This case study is the only one of the three examined where the police had a presence. Police presence is another characteristic of strike coverage and relates to the disruption and disorder frame; clearly, there is a pre-established expectation of violence on the picket line. In this particular case study, the police presence is related to the Queen's Park violence and its aftermath, in which the Metro Police Force criticized the actions of the OPP. The same table also reflects the significance of the "institutional accommodation" (Tiffen, 1988:33) afforded dominant institutionalized actors such as the government. The almost daily "informational subsidies" (Gandy, 1982:61) provided to the media by Minister Johnson, as well as those provided by Premier Harris and OPSEU President Casselman, are easily available to the Queen's Park press gallery and reporters assigned to cover the strike and reinforce the dominant frames for coverage.

Table 4 also examines primary definition, not only by showing how dominant, elite voices influence the media agenda, but by pointing out the contestation that can exist within source categories (Schlesinger, 1990:66). Although the major government and union actors maintained coherence, both Conservative MPPs and rank-and-file union members were not as monolithic in their views. Due to the over-access of elite dominant actors, these views contributed to the volume of media coverage, but were isolated and did not have a significant impact. Academics/experts were also split in their views on the strike, with a slightly higher tendency to criticize the government's position than the union's, while many took a neutral stance. This would be a significant 


\section{Table 4}

\section{Proportional Presence and Disposition of Political Actors in Mainstream Print Media Coverage on the OPSEU Strike \\ (February 25-March 31, 1996)}

consolidated news coverage in Globe and Mail, Toronto Star and Toronto Sun by percentage

\begin{tabular}{lrrrr}
\hline $\begin{array}{l}\text { Actors } \\
\text { (all references) }\end{array}$ & $\begin{array}{l}\text { Proportional } \\
\text { Presence } \\
\text { in all news items }\end{array}$ & Crisposition of Actors & \\
& Supportive & Neutral \\
\hline Party Political Actors & & & & \\
Provincial government & & & & \\
Premier \& lead ministers & 30.0 & 12.5 & 100.0 & 0.0 \\
Other Conservative politicians & 0.9 & 87.5 & 0.0 \\
Provincial political opposition & 3.0 & 100.0 & 0.0 & 0.0 \\
Provincial Speaker & 1.1 & 63.2 & 36.8 & 0.0 \\
& & & & \\
Non-Party Political Actors & & & & \\
Unions & 16.4 & 100.0 & 0.0 & 0.0 \\
Union leadership & 3.0 & 100.0 & 0.0 & 0.0 \\
Other unions & 11.7 & 82 & 23.4 & 2.5 \\
Individual members & & & & \\
Public actors \& groups & 0.2 & 0.0 & 91.8 & 8.2 \\
Supporters & 8 & 40.7 & 23.5 & 35.8 \\
Academics \& experts & 4.3 & 0.0 & 91.8 & 8.2 \\
Private sector/business & 2.1 & 33.2 & 61.1 & 5.6 \\
Lawyers/courts & 9.4 & 66.7 & 0.0 & 33.3 \\
Police & 2.0 & 14.3 & 62.9 & 22.9 \\
General public & 8.6 & 11.6 & 25.9 & 62.6 \\
Misc. & & & & \\
\hline
\end{tabular}

Figures relate to news items (only)which focused on the OPSEU strike.

Proportional presence refers to the frequency of appearance of the actor in the news item with each reference counted.

finding if academics/experts held more of a presence in the issue, but they only had an $8 \%$ proportional presence.

In Table 5, Fishman's (1980) concept of news phase structures is enlarged on in order to further 'uncover' the media coverage of the strike. In Fishman's concept, phase structures are a scheme of interpretation that structures media stories into logical chains of events that reflect journalistic news values and the structure of bureaucratic 
events (57-58). They draw attention to the relationship between news creation and the life cycle of an issue with bureaucratic origins, such as the introduction of legislation, and can partially explain a media coverage trajectory. To an extent, they are a journalistic version of Howlett's (1997) punctuated equilibrium model of policy development, in which significant events in government (such as Speeches from the Throne or introduction of legislation) can help structure policy agendas. Phase structures are sequential, have typical time durations and exhibit continuity between phases of the story (Fishman, 1980:57). They provide journalists with a ready-made, safe and socially acceptable scheme of relevance (70). They do not consist of individual events, but a logical segment of a storyline that is divided by significant events or within which smaller events occur. Thus, "routine news stories implicitly

Table 5

Phases in Mainstream Print Media Coverage
of the OPSEU Strike)
(February 25-March 31, 1996)
by number of news items
by number of news items per day (in brackets)

Phase Globe \& Mail Toronto Star Toronto Sun

\section{Strike}

February 25-March 17, 1996

(21 days)

$32(1.5)$

$41(2.0)$

$51(2.4)$

Opening of Legislature

March 18-31, 1996

(13 days)

$11(0.9)$

$29(2.2)$

$29(2.2)$

\begin{tabular}{l}
$\begin{array}{l}\text { Total news items (items per day) } \\
\text { (34 days) }\end{array}$ \\
\hline
\end{tabular}


support the status quo by taking for granted the background factors [of agency and social conditions]" (71).

Used here more broadly than conceived by Fishman, tracking coverage by phase allows analysis to demonstrate that the dominance and coherence that may be present in overall analysis is much more subtle, with different actors leading or shaping coverage at different times in the life of a news event. It also allows a more precise understanding of how different media outlets act, react and interact with actors and events and tentatively suggests there are broader, 'common-sense' understandings to news events that may go beyond news values and reflect the character of media outlets themselves. In the case of the OPSEU strike, the blackout on negotiations leaves the media to report on Johnson's frequent tallies of strikers returning to work and standard stories of public inconvenience. The Queen's Park altercation then provides the only practical division point into phases and was indeed the subject of substantial media interest as a new and newsworthy element to the overall story of the strike.

In fact, dividing the OPSEU strike into only two phases, as shown in Table 5, is revealing as it emphasizes the lack of different actors (such as the public voice in the form of families of the strikers or those who use their services and the financial hardship from striking) and the lack of context (such as background profiles of services provided by public employees and public service restructuring as a government policy linked to similar restructuring elsewhere) that could have maintained or refreshed media interest. The Toronto Star's coverage increased slightly (when calculated by news items per day) in the second phase of the strike, but otherwise, the media coverage had little to sustain it after the coverage of the altercation and was clearly in its dénouement 
phase. A different and more complex phase pattern will be revealed in the other two case studies.

Table 6 examines the extent of any challenge to the dominant actors. Again, it is starkly obvious that the newspapers under study did not depict the general public as playing a role in the strike. The citizens of Ontario that appear in media coverage are the ordinary union members on strike (see Tables 3 and 4). Even the inconvenience-tothe-public frame was actually constructed primarily not with the public in mind but as

Table 6

Authoritative Actors and Challengers in Mainstream Print Media Coverage on the OPSEU Strike)

(February 25-March 31, 1996)

by percentage

\begin{tabular}{lcl}
\hline $\begin{array}{l}\text { Main Political Actors } \\
\text { (1t reference only) }\end{array}$ & $\begin{array}{l}\text { Phase 1: } \\
\text { Strike }\end{array}$ & $\begin{array}{l}\text { Phase 2: } \\
\text { Legislature }\end{array}$ \\
\hline Provincial Government & & \\
Globe \& Mail & 30.5 & 32.9 \\
Toronto Star & 27.9 & 31.8 \\
Toronto Sun & 26 & 42.5 \\
& & \\
Unions & 31.1 & 24.3 \\
Globe \& Mail & 46.8 & 29.1 \\
Toronto Star & 45.3 & 28.8 \\
Toronto Sun & & \\
& & 0.0 \\
Challengers & 0.0 & 0.0 \\
Globe \& Mail & 0.0 & 0.0 \\
Toronto Star & 0.6 & \\
Toronto Sun & & 0.0 \\
General Public & 0.0 & 1.4 \\
Globe \& Mail & 5.3 & 1.3 \\
Toronto Star & 3.2 & \\
Toronto Sun & & \\
\hline
\end{tabular}

Figures refer to main categories of actors only.

Columns and rows do not add up to $100 \%$.

Challengers category refers to pro-government or anti-government citizens' groups. 
inconvenience to business, altercations in prisons (corrections workers are OPSEU members) and the lack of care for institutionalized psychiatric patients. These actors for the most part do not show up in the "challengers" categories in this table, but are spread across the categories of private sector and miscellaneous (inmates) and are noted in Tables 3 and 4 . The lone challenger group composed of members of the public is a group of parents of developmentally challenged children that received media coverage in the Sun and Star when, without taking sides in the dispute, they felt that they and their children were caught in the middle of it. Twenty-six such stories $(32.5 \%$ of total news coverage) appeared in the Sun, 12 stories (27.5\%) in the Globe and 9 stories $(12.9 \%)$ in the Star.

The three newspapers approached their coverage differently, in terms of the division between news stories and editorials/commentaries (see Table 7). Editorials and commentaries were not included in the content analysis in keeping with this thesis' contention that visible cracks in the dominant meaning system are not as analytically significant or interesting as their absences (Hackett et al, 1996:268-9). In other words, it would be expected that editorials and commentaries, but especially editorials, would take ideological or political positions consistent with the overall stance of the media outlet. News stories, on the other hand, offer opportunities to examine the unexpected interruptions in the meaning system as alternative or oppositional voices appear. This being said, however, editorials and commentaries related to the three case studies have been examined and will be drawn on as needed. 
Table 7

Type of Media Coverage in Mainstream Media: OPSEU Strike (February 25-March 31, 1996)

by number of items and by percentage

\begin{tabular}{lllll}
\hline Media Outlet & News Stories & $\begin{array}{l}\text { Editorials \& } \\
\text { Commentaries }\end{array}$ & $\begin{array}{l}\text { Total } \\
\text { Items }\end{array}$ & $\begin{array}{l}\text { Total } \\
\text { Items per day }\end{array}$ \\
\hline Globe \& Mail & $43(70.6 \%)$ & $11(20.4 \%)$ & 54 & 1.6 \\
Toronto Star & $70(76.1 \%)$ & $22(23.9 \%)$ & 92 & 2.8 \\
Toronto Sun & $80(66.1 \%)$ & $41(33.9 \%)$ & 121 & 3.7 \\
\hline
\end{tabular}

Table 8

Type of Media Coverage in Business Media: OPSEU Strike

(February 25-March 31, 1996)

by number of items and by percentage

\begin{tabular}{llll}
\hline Media Outlet & News Stories & $\begin{array}{l}\text { Editorials \& } \\
\text { Commentaries }\end{array}$ & Total \\
\hline Report on Business & $1(33.3 \%)$ & $2(66.7 \%)$ & 3 \\
Financial Post & $5(55.6 \%)$ & $4(45 \%)$ & 9 \\
\hline
\end{tabular}

Table 9

Type of Media Coverage in National Broadcast Media: OPSEU Strike

(February 25-March 31, 1996)

by number of items and by percentage

\begin{tabular}{llll}
\hline Media Outlet & News Stories & Features & Total \\
\hline CBC News/Magazine & $6(100.0 \%)$ & $0(0.0 \%)$ & 6 \\
CTV News/Canada AM & $2(28.6 \%)$ & $5(71.4 \%)$ & 7 \\
\hline
\end{tabular}


In the current case study, the Sun of the three media outlets examined preferred commentaries to hard news stories. As Table 7 shows, the Sun devoted one-third (33.9\%) of its coverage to commentaries, compared to $20.4 \%$ for the Globe and $23.9 \%$ for the Star. There is a tendency for a greater number of opinion pieces when there is a volatile issue in the public environment or when a newspaper for whatever reason feels strongly about an issue. A comparison with the other two case studies later in this chapter will make this clearer.

Media mapping of the public sector strike also scanned selected business coverage (Report on Business and The Financial Post) and national television news coverage ( $C B C$ and $C T V$ ) to see if the issue had national relevance and also to verify the usual presentation of labour coverage as events or "actuality without context" (Morley, 1976:260). Both business coverage and national television news were light in numbers, which held true for the other two case studies. ${ }^{14}$ Business coverage tended to commentary (see Table 8), while national television news coverage deviated sharply between the two channels, with $C B C$ presenting only news stories and $C T V$ primarily features (see Table 9). Most of the actors in the CTV features were business representatives.

Earlier in this thesis, it was suggested that the neo-liberal project has had considerable discursive resonance and success (Phillips, 1994:210, 236; Atkinson 1994b:147). Corporate and political interests are displaced into the common sense, and counter-discourse-which in any event stays within the terms of the dominant discourse

${ }^{14}$ It would be an interesting, but here unexplored, research project to examine regional coverage across Canada for levels of interest in this public sector strike. For instance, would Alberta media, given that province's neo-liberal project, have demonstrated more interest than the media in Manitoba, a province which has a social democratic government? 
Table 10

Government Messages on the OPSEU Strike

Intended

Fair and reasonable

- our offer is fair and reasonable

Fiscal reality

- fiscal constraints limit what we can offer

- our offer is reasonable given the fiscal context

The union is irresponsible and unfair

- the union is being irresponsible and greedy

- the union is not fair and reasonable

- we are protecting taxpayers from fiscally irresponsible and greedy union

The strike is a failure

- strike is having little impact on public

- strike is not successful because many are

crossing the picket lines and going to work

Public suffering and inconvenience

- the strike is upsetting public services
Actual

Fiscal reality

- the deficit does not go on strike, the debt does not go on strike; a strike will not resolve financial realities (Min. Johnson)

- province is strapped for cash and does not have the money to improve the offer (Min. Johnson)

- on behalf of people of Ontario, I can't give in to the union's rich demands (Min. Johnson)

- we are already running huge deficits; we have to stand our ground (Min. Johnson)

- we need to downsize and restructure; successor rights would shackle the government

(Min. Johnson)

\section{Business interests}

- government will stand firm to safeguard taxpayers' interests and demonstrate to the business community its resolve to cut expenditures (Premier)

- strike is a signal that the people of Ontario are determined to have a better business climate and will not be held hostage (Premier)

Fair and reasonable

- government's position is reasonable

(Min. Johnson)

Public suffering and inconvenience

- while people want a settlement, they also want one that is affordable (Min. Johnson)

- we will take whatever measures we have to take to ensure the people of Ontario are not at risk / public safety will not be jeopardized (Min. Johnson)

Right to strike and essential services

- previous government is to blame because it gave the union the right to strike; the union is now eager to taste this forbidden candy (Premier) - back-to-work legislation is a possibility; the government will not wait forever (Min. Eves)

Job security and negotiations

- government does not intend to make major modifications to its offer (Min. Johnson)

- government can't improve its contract offer (Min. Johnson)

[after new offer tabled:]

- we have offered proposals that don't cost a lot,

Message categories are in descending order of prominence.

Sources: Ibbitson (1997); news releases, Management Board of Ontanio; Globe \& Mail, Toronto Star, Toronto Sun. but offer more job security (Min. Johnson)

[after contract negotiated:]

- the agreement gives the government the flexibility it needs to lay off staff and restructure the civil service (Min. Johnson) 


\section{Table 11 \\ Challenger Messages on the OPSEU Strike}

Intended

Cooperative and Reasonable

- we recognize the need for change

- we want to work with the government

[initial message:]

Fiscal reality

- it's not about money

Provide important services

- we are ordinary members of the community who provide the services you need

\section{Efficiency}

- we have a reasonable way to make our services more effective

\section{Actual}

\section{Inconvenience}

- to be effective, the strike must be short and to be short must have as many people on strike and cause as much pain for the employer as possible (Casselman)

- it is clear the strike is having an effect (union communications director)

Right to strike and essential services

- the employer is trying to target this group

(correctional officers) to ensure there is disruption and unsafe working conditions in the facilities (Casselman)

- union rights have been stripped away in legislation and the employer is now after the rest of their rights; union members are not prepared to let that happen (Casselman)

- if the government spent half the time at the bargaining table that it has spent on (targeting) essential services, we would have a contract by now (union communications director)

Job security and negotiations

- employer is not bargaining so strike is the only option (Casselman)

- employer is now talking new (lower) numbers of people to be laid off (Casselman)

- union wants to see that workers' jobs go with the work and that pensions are not lost

(Casselman)

- employer's decision to inform media of new offer reaffirms its lack of commitment to bargaining (Casselman)

[after new offer tabled:]

- strike has forced the government to back down; the fact that the government is now bargaining in the media indicates it is worried by lack of public support (union communications director) [after contract negotiated:]

- civil servants have won major gains; they said it (a strong strike) couldn't be done and we did it

(Casselman)

- the union showed that Harris can be taken on; it was a symbolic test of the labour movement (union regional vice-president)

Business interests

- Premier is taking a tough line to boost business confidence (Opposition leader McLeod)

Message categories are in descending order of prominence.

Sources: Ibbitson (1997); communications strategy and radio advertisements, OPSEU; Globe \& Mail, Toronto Star, Toronto Sun.
Cooperation and reasonableness

- we just want to make sure we have protection in privatization plans; we just want fair treatment (Casselman) 
(Phillips, 1994:217)—remains distant from substantive economic questions (Knight, 1998:118).

Table 10 demonstrates the agenda setting and agenda building power of the government through its discursive strategy. The intended message of the government focused on the fairness and reasonableness of their contract offer, given the economic crisis faced by the province. The government intended to position itself as protecting taxpayers from the irresponsible, unfair and greedy union. This is a standard labour frame, but with the ideological twist of protecting taxpayers instead of citizens. Actual messages appearing in the three Toronto newspapers, however, emphasized the more blatantly neo-liberal fiscal reality message, both as needing to stand ground in order to resolve the deficit problem and signaling to business that it would not succumb to union 'demands'. Messages on fairness and public inconvenience were secondary to the main ideological message of the fight against the deficit. The actual messages in effect were stronger ideologically than the government had intended. This may be due partly to the nature of the government's spokespersons. Minister Johnson, the official spokesperson, took a low-key approach (Ibbitson, 1997:161) that was still firm and political, while interventions by Premier Harris were more aggressive and sparked strong reactions (and substantial media coverage). For instance, in one Toronto Star article, Johnson is quoted as saying "we will take whatever measures we have to take... to ensure the people of Ontario are not at risk" (Toughill \&Wright, 1996:A1). In the same article, Premier Harris said the union "was given this candy, this new tool [the right to strike], and they are determined to go and use it and try it". 
The union sought to appear cooperative and reasonable. It stressed that the strike wasn't about money, but job security and better treatment. Aware that it had an image problem, either as 'fat' bureaucrats (a target for neo-liberal policies) or no discernable image at all (because of its dispersed membership in different jobs and locations), the union emphasized the important impact the work of its members had on the community. This gentle message came out clearly in the union's radio ads, but did not extend to earned media coverage. The actual union messages seemed strident in their emphasis on not backing down, while the same messages from the government seemed instead to show leadership.

The ability to communicate the message is also hampered by the "he said/she said' polarization of media coverage, which, in the absence of substance, demands strong statements from the main actors. In this way, the 'fairness' message intended by both sides got lost in symbolic posturing that takes away some of the structured advantage of institutional accommodation. The communication of messages from authoritative actors is also blocked by reliance in media texts on standard labour frames. A short story in the Toronto Sun (Fehir, 1996:3) on a rally held on International Women's Day-traditionally an upbeat event that emphasizes equality and solidarityhad the headline "OPSEU leads women's charge" (OPSEU leader Casselman was a speaker at the rally). The Sun reported that, although it was "a rowdy crowd", a police staff sergeant said "the march was orderly and there were no arrests". Although such rallies are not known for violence and arrests, the Sun added a disruption and disorder frame to the story and connected it to the strike. Neither the Globe nor the Star mentioned an OPSEU connection. 
A significant omission in media coverage by all three newspapers was the lack of context to the strike, such as situating it within contested politics, pursuing historical parallels or generally just widening the range of issues related to the strike. Although there were a large number of commentaries, they did not necessarily supply context. The Sun, for instance, used its columnists and commentaries to denigrate unions in general and the public sector in particular. Its news stories were usually short and succinct, relying on eye-catching subjects (as in the swan with possible lead poisoning that could not be confirmed because the lab that did such tests was shut down by the strike) and provocative quotes, such as Transportation Minister Al Palladini saying the union "was declaring war on the people of Ontario". The exception was the Globe, which presented the views of a number of academics and experts, both in news stories and commentaries, as what Deacon and Golding (1994:14) have called "arbiters", those who are used in media stories for expert commentary and to evaluate the "advocate" sources that represent a specific point of view.

One glaring omission in all coverage, however, was the lack of coverage of the ongoing Days of Action, which were seen by challengers as carrying the voices of an increasing opposition to the Harris government. Although one such action directly preceded the strike, and received substantial coverage on its own, coverage of this action did not extend into coverage of the strike itself, which then appeared isolated and context-free. 


\section{Public Opinion}

If the general public played a role in the strike, this was not evident either in media coverage or in public opinion research. In fact, according to the polling firm used by the government, the strike was a "non-event" that "didn't capture the public mood one way or the other" (Gray, 1996:1). At least partly, this was because the strike wasn't having an impact on the public, as agreements prior to the strike left many on the job as essential services and public services continued to function reasonably well (Ibbitson, 1997:174). In itself, this was not a positive sign for the union that 55,000 public service workers could go on strike and the impact would not be seriously felt in services to the public (Van Rijn, 1996:A4). Government polling during the strike tracked the public's support of the government's position and found that it remained relatively stable, with between $48 \%$ and $54 \%$ of those polled believing the government was "being the most reasonable and fair" and between $27 \%$ and $34 \%$ choosing the union (Ipsos-Reid, 1996a, 1996b, 1996c). According to Darrell Bricker, President and Chief Operating Officer, Public Affairs of Ipsos-Reid, the key to public opinion support was "who was causing and who was solving the problem. On the 'fair and reasonable' question, the government won. OPSEU needed to be fair and reasonable and they didn't demonstrate it” (Bricker, 2002). Since content analysis shows that neither side was successful in getting out the 'fair and reasonable' message, either in so many words or by inference, some other factor must have provided that message to the public.

Other public opinion research conducted and made public during the strike present a mixed and sometimes contradictory picture, but still offers some insight. A slight majority ( $51 \%$ ) disapproved of replacement workers ('scabs') and $38 \%$ felt the 
union was being more fair-minded than the government (35\%) (Mittelstaedt \& Abbate, 1996:A1). ${ }^{15}$ When given details of the positions taken by the two sides, however, support shifted towards the government. On the government's motivation, $62 \%$ felt the government was more interested in balancing the budget than breaking the union and $72 \%$ believed the government was forced to take tough measures due to financial realities (Nesdoly, 1996:5). ${ }^{16}$

Perhaps the most condemning public opinion from the union's point of view was that $62 \%$ felt the province's unions have too much power and that collective agreements inhibit the restructuring and layoffs needed to reduce the deficit. ${ }^{17}$ The strength of this finding suggests that public opinion was drawing on Morley's (1976:247) "preestablished cultural maps of meaning" before the strike began: "The OPSEU strike looks as though it was lost before it began, as though public opinion would never shift an already truculent government" (Gray, 1996:A1). The Ipsos-Reid survey findings then gain perspective, showing the union successfully holding the line on public support in a public environment that was generally against labour. This would seem to relate back to the question of which side was more 'fair and reasonable'. Believing the government to be acting in the interests of deficit reduction, the public had already internalized the common sense belief in the need to be frugal fiscally, which overrode what in contrast seemed the ideological option of a government intent on breaking the union.

15 The poll was conducted by Decima and commissioned by Global News.

16 These figures are from the same Decima poll.

17 This was an Ipsos-Reid poll that was conducted at the end of February, just as the strike began. 


\section{Conclusion}

It was generally accepted by the government and the media that OPSEU had not gained anything from the strike. In terms of bottom-line economics, the government was able to continue with its restructuring agenda and, by one year later, had laid off 11,500 OPSEU members (Ibbitson, 1997:178). In terms of union 'psychology', the union defended the rights of its members in a strike that it was morally obliged to call in an effort to limit the damage of member layoffs as much as possible (Gray, 1996:A1). OPSEU was able to keep its first-time strike going at full pace, mobilizing and politicizing its large membership. Practically, it was able to slow down layoffs and gain some bumping rights, better severance packages and earlier access to pensions (FitzRandolph, 2002; Ibbitson \& Poling, 1996:A1). While estimates of possible layoffs had reached 27,000 , far fewer $(11,500)$ lost their jobs after the strike. It was a first and small 'blink' in the 'hit hard, hit fast, don't blink' philosophy of Canadian neoliberalism (Watson, 1997:140).

The strike was mostly fought on symbolic ground, however, with both sides hoping to achieve strategic victories. According to Queen's University Professor of Industrial Relations Pradeep Kumar in a Globe article, the battlefield was not the bargaining table but the broader public issue of government policy (Gray, 1996:A1). A Globe editorial (1996:A14) said "this strike... has evolved into a symbolic battle between labour and Tories over the size and role of government, a contrast over competing views of society. It is ultimately a battle of public opinion...". The government could have achieved its target number of layoffs through attrition (Mittelstaedt, 1996:A1), but instead weakened the public service union through Bills 7 
and 26 and moved towards a strike option (Watson, 1997:139). The union could not allow the layoff of a huge number of its members without taking a stand. The union's implied but unspoken message was: 'We are taking a political stand for and with Ontarians against the Common Sense Revolution' (Rapaport, 1999:11, 163). The government's frank and spoken message was equally ideological: 'We are determined to have a better business climate and we have to stand our ground against special interests to reduce the deficit' (see Table 10).

In the early days of the new neo-liberal government, public opinion was divided, but both the government and the union played out their standard roles in labour conflict. There were two elements missing from this polarized set-piece: the voice of the general public and the voice of challengers/opposition. Since the Harris government had targeted its first rounds of expenditure cuts at marginalized groups, such as social assistance recipients (Ralph et al, 1997:21), the general public for the most part had not yet begun to feel the impacts of Ontario neo-liberalism. Instead, there was "an emerging sense of confusion about just what the payoff [would] be when all the pain of ... the blows to the social safety net [were] complete" (Smith, 1996:A1). Missing for the public, says Ipsos-Reid vice-president John Wright, was “a vision of what Ontario's values are going to be" (A1). Challengers had already organized through the Days of Action, which were ignored by the media as possibly linked to the strike, despite its being flanked on both sides by the successful Hamilton (February 24-25) and Kitchener-Waterloo (April 19) actions. It was not as if the new government had not already experienced resistance or that it had not been reported on; the first large demonstration of opposition took place on the day of the Speech from the Throne on 
September 27 and was well-covered by the province's media. The media, primed for the traditional frames of labour-government politics, missed the larger agenda-building of both the government and challengers. The lack of coverage linking the strike to the other resistance to the government bears this out.

This case study at first glance seems an uncomplicated and routine 'us versus them' depiction of a labour strike. Further examination shows, however, that it is situated within a larger evolving transition from one political and ideological paradigm (post-war Keynesian corporatism) to another (neo-liberalism), within which there is contestation and resistance. Through its individualizing ethos and politics, neoliberalism exacerbates the increasing distance of labour in a post-industrial society from the experience of the media and the public. When in power, neo-liberal governments such as Ontario's target public sector unions for restructuring that shifts jobs to a nonunionized private sector in its deliberate "program of the methodical destruction of collectives" (Bourdieu, 1998:2). The de-collectivization allows government and the private sector to operate more efficiently without the limitations of collective agreements; further, in the case of Toronto, it gives government and business the flexibility to promote the city as a competitive global city. In a post-industrial, serviceoriented, largely non-unionized society, in which the government constructs a constant neo-liberal message of crisis due to the self-interest and greed of groups such as strikers, there is less patience, regard or sympathy for collective union action. In this first cross-province collective action by a single such 'interest group', strong public anti-union sentiment co-exists with confusion on the direction of the province (Smith, 1996:B1). 
The disruption frame in this case study demonstrates the emerging strategy of the Ontario government in limiting opposition to its policies. The disruption frame and polarized discourse of labour strife already creates an image of strikers that locates them near the edge of the acceptable limits of society. Beginning in 1984, the federal government delegitimated and marginalized the role and contribution of labour to society, shifting it from its dual location in the dominant meaning system, as one of a community of mediators around the table in government consultations (Atkinson, 1989:105), and the alternative meaning system, as an actor testing the limits of society within a social system where labour job action is tolerated. The Ontario neo-liberal government, as it did in its first few months of office with other marginalized groups, now constructs an image of labour as working against the interests of a society in crisis, shifting it to the oppositional meaning system (as an actor not tolerated by society). In the perspective of the Ontario government, labour joins welfare mothers, young offenders and the homeless as 'unworthy'. In the next case study, the government continues to challenge the legitimacy of opposition to its emergent hegemony and further develops strategic tactics and messages to reduce the impact of opposition. 


\section{Case Study 2: The Amalgamation of Toronto and Megaweek}

\section{Introduction}

The second case study picks up 10 months after the OPSEU strike. The intervening time was characterized by a continuing policy, legislative and communications offensive by the government (Ralph et al, 1997), matched by continued public opposition and several more of the Days of Action. ${ }^{18}$

In the second week of January 1997, the Harris government announced a series of initiatives that profoundly changed the way government would function in relation to the citizens of Ontario. The "staggering list of changes to the way Ontario is governed" (Abraham, 1997:A1) included: elimination of the Landlord and Tenant Act and rent control; amalgamation of Toronto with five surrounding municipalities; reduction or elimination of some local control of public schools; elimination of citizen review of police shootings; and elimination of some environmental protections. Also facing major jurisdictional shifts and changes were social assistance, long-term health care, children's aid societies, women's shelters, ambulance services, social housing, public health programs and public transit (Ralph et al, 1997). The Megaweek ${ }^{19}$ announcements shifted funding for a wide range of jointly funded services from the provincial income tax base to the municipal property tax base. In return for the

\footnotetext{
18 These took place in Kitchener-Waterloo on April 21, Peterborough on June 24 and Toronto on October 24-25, 1997.

19 Toronto newspapers quickly took to the term "megacity", with all three using it on December 18, the day after the amalgamation announcement. "Megaweek", however, was rarely mentioned by the media and was more of a construct of the opposition to the government. It was used in a derogatory way to criticize the breadth and audacity of the initiative and was parodied further as 'megaweak' in reference to the government's perceived attack on the weak.
} 


\section{Figure 12}

\section{Chronology: Amalgamation of Toronto and Megaweek}

October 17, 1996

October 25-26, 1996

October 30, 1996

December 16, 1996

December 17, 1996

December 23, 1996

January 13-17, 1997

January 22, 1997

January 29, 1997

February 3, 1997

February 15, 1997

February 26, 1997

February 28, 1997

March 3, 1997

March 21-22

March 27, 1997

April 2, 1997
Bill 86, Better Local Government Act, which cuts down on the number of municipal politicians across the province (effective as of the fall 1997 municipal elections), is introduced

Toronto Days of Action

Premier's Office leaks Premier Mike Harris's preference for single-city amalgamation option

Government-commissioned report on amalgamation, Fresh Start, by KPMG released and Citizens for Local Democracy holds its first meeting

Bill 103, City of Toronto Act (amalgamation), is introduced

David Crombie report on 'who does what' (provincial and municipal disentanglement) is tabled

Megaweek: four days of major restructuring announcements on the disentanglement of education, social services, transportation and property assessment

The Speaker of the Ontario legislature rules that part of the government's advertising campaign on disentanglement places Municipal Affairs minister Al Leach in contempt of the legislature

Second reading, Bill 103 (amalgamation)

Five weeks of hearings on Bill 103 (amalgamation) begin

parade and demonstration sponsored by Citizens for Local Democracy down Yonge St.

Deloitte \& Touche report contradicts KPMG's assessment and says amalgamation would bring no significant savings

Ontario Court rules the government broke the law by appointing trustees to oversee amalgamation before Bill 103 was passed

Referenda on amalgamation held by the six municipalities of the Greater Toronto Area shows $76 \%$ of those who voted are against amalgamation

Sudbury Days of Action

Amendments to Bill 103 with minor reforms tabled

Liberals and NDP table 11,000 amendments to Bill 103 that keep the legislature voting continuously for 10 days 
April 21, 1997

Bill 103 passes and receives Royal Assent as Citizens for Local Democracy and other protestors demonstrate outside legislature

April 28, 1997 Thunder Bay Day of Action

July 24,1997

Ontario Court rules that Bill 103 did not violate charter rights, but criticizes the lack of consultation and says the government "exhibited mega-chutzpah in proceeding as it did"

download to municipalities, the province partially took on educational property taxes.

Not only is tax based on property more regressive than income tax, but smaller Ontario communities would not be able to fund services because of a limited property base (Financial Post, 1997:18). Thus Megaweek policy initiatives broke the fundamental operating principle of equality of programs and services that Canada traditionally had accorded its citizenry.

This case study will focus on the announcement on the amalgamation of Toronto that became known as the "Megacity bill", more formally as Bill 103, the City of Toronto Act. The bill was introduced into the Legislature on December 17, 1996, prior to Megaweek. It nonetheless became integrally connected with the massive restructuring introduced during that week and led to public confusion between the Megaweek announcements as a whole, which were part of a process known as 'disentanglement', and the merger of Toronto with five surrounding municipalities, which was 'amalgamation' (Ibbitson, 1997:252-3). The bill was voted into law April 21,1997 , but not before a campaign to oppose the bill dominated the public and media agendas in Toronto.

Although municipal restructuring was contained in the Conservatives' election platform, the Common Sense Revolution, the government nonetheless had committed itself ideologically to both balance the provincial budget and lower income taxes by 
30\% (Boudreau, 2000:5), which would not have been achievable without the savings incurred through amalgamation and disentanglement. In addition, some of the first public opinion research conducted by the new government focused on municipal changes (Environics, 1995), a sign that municipal issues were under scrutiny by the government.

Municipal restructuring was not a new debate, but part of a decades-long struggle on shaping Toronto that was intensely political. The Toronto business community, including the Toronto Board of Trade, had long supported amalgamation and the Megacity plan was thus "the consolidation of the long-standing governance and administration program of a particular urban regime" (Todd, 1998:201). Disentanglement was the subject of studies by former Toronto Mayor (and Conservative) David Crombie and president of the United Way, Anne Golden, each with his or her own blueprint of how Toronto should look, and, with the help of polling, the Conservatives were also developing their own plan.

Politically, Metro Toronto had built a progressive reputation for community interest and activism in local and neighbourhood affairs and tended to vote Liberal or New Democrat provincially. The surrounding communities-East York, Etobicoke, North York, York and Scarborough—which were known as the ' 905 belt' after their long-distance telephone code, did not have that history and tended to support the Conservatives (Boudreau, 2000:117). The political stance of metro Toronto was reflected in its city council, under Mayor Barbara Hall, which had taken high-profile public positions against the new provincial government (Ibbitson, 1997:242-3). Disentanglement and amalgamation together would put an end to Toronto city council 
and its influence. In the same way that the government removed labour rights by legislation prior to the OPSEU strike, it passed the Better Local Government Act in the fall of 1996. The Act legislated fewer municipal politicians throughout the province, effective in the 1997 municipal elections. The bill in effect removed the power of Toronto city council by rendering it obsolete, a 'lame duck' council.

\section{Government Communication Strategy}

A further sign that the new government had its own views on municipal restructuring were revealed when Municipal Affairs Minister Al Leach introduced Bill 103 for first reading on December 17, 1996, without waiting for Crombie's report on disentanglement, which was due to report. A day earlier, a KPMG report commissioned by the government said amalgamation would save the province $\$ 300$ million a year. ${ }^{20}$ Although amalgamation could also have been implemented in the municipalities outside the Greater Toronto Area, Conservative MPPs from those '905' areas did not support that extension of amalgamation to their constituencies (Ibbitson, 1997:248). Lastly but importantly, Premier Harris intended to make Toronto "politically more coherent and competitive" to become a globally competitive city-state (241-243.

The opposition to the Megacity did not gather speed until after the widespread publicity and reaction to the Megaweek announcements of mid-January. By that time the six mayors, of Toronto and the five municipalities, had produced their own report condemning the government's plan. The growth of opposition to what was seen as the end of local government was helped by a court ruling that ruled that trustees appointed

20 Minister Leach announced the new legislation at a breakfast meeting of the Toronto Board of Trade before the bill was tabled in the legislature later that day (MMAH, 1996a). 
by the government to oversee amalgamation did not have authority until the legislation was passed. The court challenge was launched by a prominent challenger group called Citizens for Local Democracy (C4LD), which had just been founded by another former Toronto mayor, John Sewell, in response to the Megacity bill. ${ }^{21}$ Another blow to the government plan was the release of a report by Deloitte $\&$ Touche that contradicted KPMG's assessment that $\$ 865$ million could be saved in the first three years after amalgamation and instead said there would be no significant savings (Ross \& Rusk, 1997:A1). David Crombie also commented negatively on the plan, as did several Conservative MPPs whose constituencies would be affected.

Other events and actions that drew attention to the Megacity issue included the intensive lobbying by Citizens for Local Democracy for hearings on Bill 103 and for speaker status at the hearings (Rykert, 2003); ${ }^{22}$ a C4LD parade on February 15 down Yonge Street with actor Eric Peterson playing William Lyon MacKenzie, first mayor of Toronto; and referenda held on March 4 by each of the five municipalities to be amalgamated with results showing $76 \%$ against the plan. ${ }^{23}$ These newsworthy events kept the Megacity issue prominent in local news.

As with Bill 26 and unlike the careful planning that went into the legitimation of the Common Sense Revolution, the government did not have an initial communications plan to support the Megacity legislation. ${ }^{24}$ The government's 'plan' was to overwhelm

21 The government responded by changing the trustees' role into an advisory capacity, which meant the three appointees could continue their work.

22 The hearings eventually heard more than 500 deputations, a majority of them opposing the Megacity. Isin (1998:180).

${ }_{23}$ Overall turnout was 30\%, which was comparable to municipal election turnout (Boudreau, 2000:15).

24 This was ascertained through a request to the Freedom of Information and Personal Privacy Act. As specific issues emerged, however, communications plans were developed to support the government's 
the public, the partisan political opposition and the media with a blitzkrieg of announcements, part of the 'divide and conquer' tactics established early in their mandate. Amalgamation and disentanglement were already confusing, but no visible attempt was made to clarify the distinction; instead the government "attacked on all fronts at once, paying whatever the political price" (Ibbitson, 1007:269). Before hearings were held, the government was clear that it would not make major changes to the Megacity bill and would continue to pursue its agenda (Rusk \& Abbate, 1997:A5; Boudreau, 2000:60). It was clear that the government's strategy was also to move quickly through the legislative process by conducting limited hearings on the issue. When intense lobbying created unprecedented demand for representation at the hearings, the government increased the hearings from two to five weeks. ${ }^{25}$ During the hearings, the legislature was not in session, which removed daily question period from the scrutiny of partisan opposition and the newsmaking apparatus of Queen's Park. At the same time, however, this focused media attention on the hearings themselves.

The government's messages concentrated on the neo-liberal issues of lowering costs, increasing efficiency and removing barriers to investment which would then enable the private sector to create jobs (MMAH news releases). The underlying message was the government's continued commitment to reduce the deficit and cut

position on the trustees and after the hearings. A set of backgrounder papers was also developed after the hearings (Ministry of Municipal Affairs and Housing documents, 1997).

25 Based on an examination of legislature documents of the current and previous government in Ontario, hearings on proposed legislation can last anywhere from one or two days to one or two months, depending on the complexity and potential impacts of the legislation. Traditionally, hearings were held throughout Ontario. While two weeks was a somewhat short period of time, signalling the government's reluctance to prolong public input into a bill to which it had already stated it would not make changes, five weeks would seem to be reasonable, although hearings were held only in Toronto (Ottawa and Hamilton, also facing future amalgamation, also had an interest in the issue). 
income taxes in response to the economic crisis facing the province (Boudreau, 2000:123).

\section{Challengers and their Communication Strategies}

The opposition to the Megacity comprised two main fronts: the municipal politicians and segments of the public as channelled through Citizens for Local Democracy. The municipal politicians had a separate voice and presence in the media. The six mayors of Toronto and the municipalities acted in common on the critical issue of referenda to be held on the Megacity, although different points of view were expressed within that loose coalition. They also had a strong presence at the hearings, but once again took different points of view within the overall umbrella of opposition The municipalities were able to use the authority and resources of their institutionalized positions to promote their points of view.

The most organized and visible opposition, however, came from C4LD, which in a short time gained prominence and influence with the public and the media. C4LD was loosely organized, with a 16-member steering committee making decisions consensually which then were endorsed at the group's well-attended Monday night meetings by a show of hands (Rykert, 2003). The organization had no membership list (Boudreau, 2000:10), but it did develop a sophisticated and successful communications system centred on initial announcements and fresh information at Monday night 
meetings and distribution of the message through broadsheet newsletters, a telephone hot-line and an extensive e-mail network. ${ }^{26}$

C4LD saw itself as a "catalyst to attract... energy and mobilize for resistance" (Boudreau, 2000:40). Liz Rykert, one of the core members who is also credited with setting up the group's extensive electronic organization, says the group tried to act as a social movement (Rykert, 2003). C4LD focused on three strategic areas: the hearings, electronic communication and the referenda. Rykert says the referenda moved the group into "campaign mode", which gave the newly involved participants something concrete to do; "foot soldiers become critical in a campaign" (2003). Rykert says the group was well-resourced, mostly from 'passing the hat' at meetings and had little problem in gaining access to most media. One person on the advisory committee looked after media relations and organized news conferences. John Sewell's contacts as former mayor and journalist brought in high-profile speakers who could be promoted in the media, which also sustained the group's profile (Rykert, 2003). An example is the parade down Yonge Street on February 15, in which actor Eric Peterson, playing the role of Alexander Mackenzie, re-enacted the rebellion of 1837. Called the "Rebellion of 97 Democracy Parade", it was well-reported in the three newspapers. Other prominent figures against amalgamation who spoke at C4LD meetings or at hearings included urban planning expert Jane Jacobs, internationally known physicist and educator Ursula Franklin, then-NDP leader Alexa McDonough and writer Margaret Atwood.

26 The group's e-mail communication system contained three separate list-serves (Boudreau, 2000). As an example of the strength of its communications efforts, 60,000 tabloid-style newsletters were distributed in the pre-referenda time period (Rykert, 2 May 2003). At the height of C4LD activity prior to the referendum, its web site was visited between 16,000 to 18,000 times per week (Gordon, 1997:A6). 
Sewell's leadership role in C4LD, along with Rykert's visibility as a coordinator, points out that these 'ordinary citizens' were also educated, middle-class, urban citizens that formed an authoritative counter-elite. Although Rykert believed C4LD had considerable reach within those parameters, she was aware that C4LD spoke for and alongside with, for the most part, a certain grouping of like-minded citizens (Ross, 1997:A3; Rykert, 2003). When 'the hat was passed' at meetings, no doubt these citizens had the personal resources to give generously.

Beyond the municipal opposition and the C4LD opposition, the partisan political opposition was also active against the Megacity. The opposition received some support from backbench Conservative MPPs, and they became a target of challenger strategies to convince the dissenters to get their leadership to back down (Ibbitson, 1997:262). The two opposition parties had different positions on the Megacity within the opposition. The Liberals wanted the legislation to be delayed for a year, while the NDP wanted the bill to be withdrawn. When the legislature reconvened and the bill was due to be passed, the NDP filibustered for 10 days by forcing votes on 12,000 amendments. When the amendments were challenged by the government, the Speaker (himself a Conservative) ruled they were in order (266).

While the municipal opposition concentrated on communications messages that decried the excessive speed of the restructuring and the government's lack of flexibility, C4LD promoted the view that amalgamation was a threat to local democracy and that the government had lost its legitimacy because it didn't consult the people who would be affected. Related messages used by C4LD and its supporters (many of which are echoed at the hearings) included: the cost of amalgamation; that it would create bigger, 
more distant government; that it was the beginning of privatization of local services; and that it would force the urban and suburban lifestyles into one jurisdiction (Boudreau, 2000:13). C4LD thus positioned itself as a democracy watchdog, defending local democracy against the government $(49,70)$.

\section{Media Coverage}

The three Toronto and area newspapers supported amalgamation editorially, but criticized disentanglement. In their daily coverage, material for news reports was constantly available; at one point it was estimated that 15 meetings were taking place nightly across the Toronto area for and against amalgamation and coverage reflected a range of opinion and coverage of events. ${ }^{27}$ The high level of media coverage may have been a mixed blessing; at one point C4LD organized a boycott of the Star because of its negative portrayals of the group (Boudreau, 2000:71). The Globe (1997:22) described C4LD members as "urban guerilleros" and the Sun (1997:10) called them "antieverything zealots", thus depicting them as radicals, instead of ordinary citizens (Boudreau, 2000:78). In one editorial (1997:E2), the Star called the rhetoric of the opposition "reckless": "No claim seems too outlandish, no hyperbole too outrageous". The purpose, according to the Star, was "not so much to inform, but foment dissent, stir up anger, confuse, befuddle, scaremonger and defeat Bill 103" (E2). Although C4LD felt it generally had good access to the media, Rykert felt it had a harder time with the Toronto newspapers because of their pro-amalgamation editorial stance (Rykert, 1997).

27 On February 19, the Toronto Star sent reporters to 19 of the 27 meetings on amalgamation held that night in Toronto. Seventeen of the meetings were organized by Conservative MPPs to support the government's message. 
Rykert suggests that the three newspapers were for amalgamation because they would be able to extend their reach to a much larger market (2 May 1997).

The Toronto media in fact, as Table 13 shows, gave considerable space to authoritative political sources, at $59.8 \%$ for the Globe, $57.2 \%$ for the Star and $73.8 \%$ for the Sun. As in the poll tax case in Great Britain, municipal involvement in the issue added a whole tier of authoritative actors which increases their number of references

Table 13

Political Actors in Mainstream Print Media Coverage

on the Megacity

(December 17, 1996-April 21, 1997)

by media outlet

by percentage

\begin{tabular}{lll}
\hline $\begin{array}{l}\text { Actors } \\
\left(1^{\text {st }} \text { reference only }\right)\end{array}$ & Globe \& Mail & Toronto Star Toronto Sun \\
\hline
\end{tabular}

Party Political Actors

Provincial government

Premier \& lead ministers

Other Conservative politicians

24.4

12.1

9.7

23.1

Provincial political opposition

28.8

Provincial Speaker

2.1

0.9

0.5

6.8

Federal politicians

1.0

29.9

29.9
1.3

6.1

Non-Party Political Actors

Public actors \& groups

Challengers (i.e. C4LD)

Supporters

Academics \& experts

16.0

0.3

3.9

3.4

Private sector/business

Lawyers/courts

General public

6.8

15.1

1.0

4.3

1.3

2.0

1.2

12.4

4.0
11.3

0.2

3.7

2.8

0.4

1.1

3.3

4.6

Figures relate to news items (only) which focused on the megacity.

Figures refer to the first reference to the actor in the news item. 
overall in media reports (Deacon \& Golding, 1991:305). While the Sun (at 29.9\%) and the Star (at 28.8\%) accord the municipal tier significant coverage, the Globe, which is not known for its 'local' coverage, gives it only secondary status (at 15.0\%), instead giving more voice to non-party, but still authoritative, actors. With such high reliance on primary definition and, presumably, institutional accommodation, opportunities for the dominant or preferred readings (Hall et al, 1978) are considerable.

As with the poll tax case, not all authoritative references supported the expected political position. Conservative politicians other than the Premier and the lead ministers often spoke out against their government's position ( $14.6 \%$ of those cited in the media coverage were critical), as Table 14 shows. Although this figure may seem low, it is unusual for government members to break caucus silence, unless the issue is controversial and/or unless there is a large number of backbenchers with little authority. This lack of cohesion extended to the municipal politicians, with $7.5 \%$ supportive of the government against the majority of their peers. Federal politicians representing Toronto and area ridings who were asked to give their opinion on amalgamation were unsure of how to evaluate the issue, as the division of opinion among the three positions (supportive, critical or neutral) shows. This is significantly different from the OPSEU case, where opinion was polarized and actors knew their parts.

Public actors such as Citizens for Local Democracy had a strong presence in the Toronto media (with a $13.9 \%$ proportional presence), as did the general public (at 7.3\%), relative to the OPSEU case in which there was to all intents and purposes no public presence. Tables 13 and 14 also show the Globe citing more non- 
Table 14

Proportional Presence and Disposition of Political Actors in Mainstream Print Media Coverage on the Megacity (December 17, 1996-April 21, 1997)

consolidated news coverage in Globe and Mail, Toronto Star and Toronto Sun by percentage

\begin{tabular}{lllll}
\hline $\begin{array}{l}\text { Actors } \\
\text { (all references) }\end{array}$ & $\begin{array}{l}\text { Proportional } \\
\text { Presence } \\
\text { in all news items }\end{array}$ & Critical & Supportive & Neutral \\
\hline
\end{tabular}

Party Political Actors

Provincial government

Premier \& lead ministers Other Conservative politicians

Provincial political opposition

Municipal political opposition

Provincial Speaker

Federal politicians

Non-Party Political Actors

Public actors \& groups

Challengers (i.e. C4LD)

Supporters

Academics \& experts

Private sector/business

Unions

Lawyers/courts

General public

Misc.

$\begin{array}{rrrr}23.6 & 0.5 & 99.5 & 0.0 \\ 7.5 & 14.6 & 78.3 & 7.1 \\ 3.8 & 100.0 & 0.0 & 0.0 \\ 26.8 & 85.6 & 7.5 & 6.9 \\ 1.7 & 7.4 & 0.0 & 92.6 \\ 1.4 & 71.4 & 16.1 & 12.5\end{array}$

$\begin{array}{rrrr}13.5 & 100.0 & 0.0 & 0.0 \\ 0.4 & 0.0 & 86.7 & 13.3 \\ 3 & 65.2 & 17.7 & 17.1 \\ 2.6 & 47.6 & 40.7 & 11.7 \\ 1.6 & 100.0 & 0.0 & 0.0 \\ 1.2 & 89 & 8.7 & 40.7 \\ 7.3 & 63.9 & 12.2 & 3.9 \\ 3.1 & 69.7 & 21.3 & 9.0\end{array}$

Figures relate to news items (only) which focused on the megacity.

Proportional presence refers to the frequency of appearance of the actor in the news item with each reference counted each reference counted.

partisan authoritative sources such as academics, the private sector and lawyers than either of the Star and the Sun. The latter, despite its populist format and circulation, gave comparatively little space to public actors and the general public. Sun commentary and editorials were strongly against the growing citizens' movement, with its liberal and collective focus on democracy, presumably because it did not reflect the individualized direct democracy of the New Right that was more in keeping with the Sun's stances. 
In terms of the different phases of the megacity story, this and the subsequent case study follow a path that is paid out by legislative phases. The first phase begins with the introduction of the bill (normally this takes place in the legislature) and lasts until the Megaweek announcements, a series of high-profile initiatives with strong potential for media coverage by being government-based, involving unprecedented change and large amounts of money, invoking negative reaction from the partisan opposition and having an impact on a large number of Ontarians. The second phase ends as the consultations on the bill begin—again, this phase has a bureaucratic point within the policy cycle with potential for the media to profile negative reaction to the proposed legislation and pursue different story angles. This third phase naturally covers the five weeks of hearings and is then followed by the amendments phase, when the action returns to the legislature and the parliamentary process.

The consultations phase of the Megacity issue was covered widely by all three media outlets (see Table 15). The Sun reserved most of its coverage (62\%) for this phase. Even when calculated at the number of news items per day in order to compensate for the different lengths of the phases, the Sun devotes considerable attention to the hearings. The Globe tended to devote more space to the official segments of the policy-legislative cycle, such as the introduction of the legislation (at $20.1 \%)$ and the Megaweek announcements $(21.9 \%$, but with a stronger presence if calculated by items per day). By volume alone, the Star devoted considerable coverage to the issue, with 219 articles, three times the Globe's coverage and almost twice the Sun's coverage. By virtue of high volume alone, the Star was signaling the importance 
Table 15

Phases in Mainstream Print Media Coverage of the Megacity

(December 17-April 22, 1997)

by number of news items

by number of news items per day (in brackets)

\begin{tabular}{|c|c|c|c|}
\hline Phase & Globe \& Mail & Toronto Star & Toronto Sun \\
\hline $\begin{array}{l}\text { Introduction of Legislation } \\
\text { December } 17 \text {-January } 12,1997 \\
\text { (26 days) }\end{array}$ & $15(0.6)$ & $38(1.5)$ & $14(0.5)$ \\
\hline $\begin{array}{l}\text { Megaweek Announcements } \\
\text { January 13-February 2, } 1997 \\
\text { (20 days) }\end{array}$ & $16(0.8)$ & $43(2.2)$ & $17(0.9)$ \\
\hline $\begin{array}{l}\text { Consultations } \\
\text { February 3-March 26, } 1997 \\
\text { (51 days) }\end{array}$ & $31(0.6)$ & $123(2.4)$ & $75(1.5)$ \\
\hline $\begin{array}{l}\text { Amendments and Passage } \\
\text { March 27-April 21, } 1997 \\
\text { (26 days) }\end{array}$ & $11(0.4)$ & $15(0.3)$ & $11(0.4)$ \\
\hline $\begin{array}{l}\text { Total news items (items per day) } \\
\text { (123 days) }\end{array}$ & $\overline{73(0.6)}$ & $219(1.8)$ & $117(1.0)$ \\
\hline
\end{tabular}

it attached to the Megacity issue; its characterization of the issue would then assume more importance for its readers. This table also reveals how the Sun was slow to see the amalgamation issue as significant, lagging behind both the Globe and the Star in terms of amount of coverage (12.0\%) in the first phase. This could have been because of its general right-wing ideological stance, or it could be that the Sun, taking its cue from the government, simply did not anticipate the eventual volatility of the issue.

Looking at the main actors and challengers involved in the megacity issue, as shown in Table 16, it becomes clear which actors and meaning systems (Williams, 
Table 16

Authoritative Actors and Challengers in Mainstream Print Media Coverage on the Megacity

(December 17-April 22, 1997)

by percentage

\begin{tabular}{|c|c|c|c|c|}
\hline $\begin{array}{l}\text { Main Political Actors } \\
\left(1^{\text {st }} \text { reference only) }\right.\end{array}$ & $\begin{array}{l}\text { Phase 1: } \\
\text { Legislation } \\
\text { (26 days) }\end{array}$ & $\begin{array}{l}\text { Phase 2: } \\
\text { Announcement } \\
\text { (20 days) }\end{array}$ & $\begin{array}{l}\text { Phase 3: } \\
\text { Consultations } \\
\text { (51 days) }\end{array}$ & $\begin{array}{l}\text { Phase 4: } \\
\text { Amendments } \\
\text { (26 days) }\end{array}$ \\
\hline \multicolumn{5}{|l|}{ Provincial Government } \\
\hline Globe \& Mail & 23.0 & 31.3 & 19.6 & 30.4 \\
\hline Toronto Star & 17.9 & 10.6 & 8.2 & 20.5 \\
\hline Toronto Sun & 22.2 & 26.2 & 21.9 & 29.4 \\
\hline \multicolumn{5}{|l|}{ Municipal Government } \\
\hline Globe \& Mail & 25.7 & 9.4 & 16.2 & 5 \\
\hline Toronto Star & 35.4 & 23.7 & 20.8 & 13.3 \\
\hline Toronto Sun & 40.0 & 19.7 & 32.3 & 21.6 \\
\hline \multicolumn{5}{|l|}{ Challengers } \\
\hline Globe \& Mail & 2.7 & 28.1 & 16.8 & 16 \\
\hline Toronto Star & 3 & 18.4 & 10.9 & 18.1 \\
\hline Toronto Sun & 6.8 & 11.5 & 8.8 & 29.4 \\
\hline \multicolumn{5}{|l|}{ General Public } \\
\hline Globe \& Mail & 9.5 & 28.1 & 6.2 & 5 \\
\hline Toronto Star & 12.7 & 23.3 & 36.7 & 1.2 \\
\hline Toronto Sun & 8.9 & 3.3 & 4.0 & 0.0 \\
\hline
\end{tabular}

Figures refer to main categories of actors only.

Columns and rows do not add up to $100 \%$.

Challengers category refers to anti-amalgamation groups and individuals.

Bolded figures indicate highest value in the phase by news outlet.

1977) held the attention of the media in the different phases of the issue cycle. In the first phase of the issues, all three media outlets highlighted municipal reaction to the government announcement. This also shows up in the OPSEU case, where the first phase of the strike gives the union slightly more profile than the government (see Table 6). In the second phase, in which the Megaweek announcements are made, the Globe 
and the Sun gave more profile to the government, but the Star maintains focus on the municipal tier. In the third phase, in which consultations take place, there was no unanimity amongst the three media outlets. The Globe was more focused on the provincial government, the Sun on the municipal government and the Star on the general public. This reinforced the lack of coherence in government and oppositional messages which became more evident during the hearings. In the last, legislative phase of the issue, all three outlets gave more prominence to the provincial government (the Sun also favouring to the same degree the general public). The Globe's storyline remained consistent, beginning with the reaction focus and returning to the authoritative actors and events that structure a policy cycle. The Star focused on the main authoritative opposition for the first two phases, provided significant coverage of general public opinion in the third phase and then returned to the provincial government for the end of the policy cycle. The Sun started with the municipal, government, as did the other media outlets, went to the provincial government for the Megacity announcements, returned to the authoritative opposition (the municipal government) for the consultations phase and then focused on the provincial government in the last, amendment phase.

A logical storyline for a policy-legislative cycle would start with an announcement and the reaction of the main opposition, follow with a focus on the hearings and return to the Legislature for final passage. In the Megacity issue, the first and fourth phases are consistent with this storyline and all three media outlets analyzed follow this path. In the middle two phases, however, there is no coherence amongst the three; the Globe sticks with authority, the Sun goes for the acceptable opposition and 
specific time-period bounded at the beginning with the announcement and at the end by the consultations, has the confusing anomaly of a second set of announcements. Again, the third phase of consultations, there is confusion where there should be clarity. Although only the Star chose the logical focus in the consultations phase (which is on those being consulted), this is a mixed blessing for the opposition, as the majority of the Star's news stories on the hearings were little more than short summaries of each presentation, presented without context or attention to the thread of the argument. Thus quantified as little more than 'pros' or 'cons' on the issue and decontextualized, the coverage, although considerable, does not reveal the actual lack of cohesive messages brought to the hearings by a wide range of citizens. Its coverage instead seemed only to pay lip service to the Star's own imperative to provide metro news.

Thus, Table 16 shows that the amalgamation story was already over as a salient issue in the last, amendment phase, as media coverage had declined, despite challenger activity. In contrast, the UK poll tax debate showed continued salience in this phase (Deacon \& Golding 1991) that contributed to a crisis in leadership and the downfall of Prime Minister Thatcher (Bruce, 1992), in addition to the failure of the initiative itself. The findings in this table are consistent with the declining media profile and efficacy of C4LD as a challenger group (Rykert, 2003).

Table 17 looks at the amount of commentary relative to the news coverage in the three media outlets. In the OPSEU case, with its set actor categories and points of view, only the Sun's news:commentary ratio was higher. Here, both the Globe (at 50.0\%) and the Sun (47.1\%) showed significantly elevated numbers of commentaries and 
Table 17

Type of Media Coverage in Mainstream Media: Megacity (December 17-April 22, 1997)

by number of items and by percentage

\begin{tabular}{lrrrr}
\hline Media Outlet & News Stories & $\begin{array}{l}\text { Editorials \& } \\
\text { Commentaries }\end{array}$ & $\begin{array}{l}\text { Total } \\
\text { Items }\end{array}$ & $\begin{array}{l}\text { Total } \\
\text { Items per day }\end{array}$ \\
\hline Globe \& Mail & $73(50.0 \%)$ & $73(50.0 \%)$ & 146 & 1.2 \\
Toronto Star & $219(76.0 \%)$ & $69(24.0 \%)$ & 288 & 2.3 \\
Toronto Sun & $117(52.9 \%)$ & $104(47.1 \%)$ & 221 & 1.8 \\
\hline
\end{tabular}

Table 18

Type of Media Coverage in Business Media: Megacity

(December 17-April 22, 1997)

by number of items and by percentage

\begin{tabular}{lllc}
\hline Media Outlet & News Stories & $\begin{array}{l}\text { Editorials \& } \\
\text { Commentaries }\end{array}$ & Total \\
\hline Report on Business & $0(0.0 \%)$ & $1(100.0 \%)$ & 1 \\
Financial Post & $1(12.5 \%)$ & $7(87.5 \%)$ & 8 \\
\hline
\end{tabular}

Table 19

Type of Media Coverage in National Broadcast Media: Megacity (December 17-April 22, 1997)

by number of items and by percentage

\begin{tabular}{lccc}
\hline Media Outlet & News Stories & Features & Total \\
\hline CBC News/Magazine & $2(66.7 \%)$ & $1(33.3 \%)$ & 3 \\
CTV News/Canada AM & $4(80.0 \%)$ & $1(20.0 \%)$ & 5 \\
\hline
\end{tabular}


editorials. The Star, although it had a much larger body of news coverage than the other two outlets, only had $24.0 \%$ commentaries and editorials, choosing to cover the story as news. Putting the Star's news orientation here together with its coverage in the consultations phase, which was significantly higher than the other two newspapers (see Table 16), it appears the Star was making a conscious effort to appear neutral while at the same time it also provided painstakingly complete coverage, including diverse points of view. Looking at the content of the editorials, however, it is clear that the Star did not support amalgamation, criticizing both the content and style of C4LD's campaign (1997:E2).

A scan of business coverage in Report on Business (ROB) and The Financial Post (FP) showed a low degree of interest in the Megacity issue (see Table 18). The single ROB story and seven of the eight FP stories were commentaries. The ROB story criticized amalgamation as "merely an exercise in central planning" and the government as appearing not "to have any genuine reform policies". (1997:B2). Financial Post stories focused on the "vested interests" (Francis, 1997:13), "self-serving elites" (Frum, 1997:24) and "self-centred hysteria" (Segal, 1997:28) of the anti-amalgamation forces. Both the $\mathrm{CBC}$ and CTV national news broadcasts covered the amalgamation story, mostly highlighting the strong opposition to the initiative (see Table 19). Both networks referenced internal government dissent from its backbenchers.

Tables 20 and 21 look at the discursive strategies of the government and opposition. The government intended to highlight amalgamation as a lesson in neo- 
Table 20

\section{Government Messages on the Megacity}

Intended

Doing better for less

- a single unified Toronto will save money

- local government will be streamlined, more

efficient

- one Toronto will reduce duplication and overlap

Good for Investment

- a single unified Toronto will remove barriers to growth and investment / cut red tape

- a single unified Toronto will create jobs residents, taxpayers and business will all benefit from one Toronto

- local government will be more accountable - one Toronto for all of us

Govermment will be more local

- people will have better access to local government

- individual neighbourhoods will remain strong and vital

[added after public hearings:]

Listening to people

- we have listened to people's concerns during the

public hearings and we are responding

- citizens will continue to have their say through public consultations
Everyone will benefit

Actual

Moving ahead

- we will not withdraw the bill / delaying the bill is

like withdrawing it (Min. Johnson)

- we will create megacity despite referendum

results; the referenda are rigged (Min. Leach)

- although not as we proposed it, the bill still has

all our principles (Premier)

- we're making the tough decisions/we're in a mess because (previous) governments didn't have the courage to make decisions (Premier)

- we've made commitments and promises and we're going to keep them (Min. Leach)

- the status quo is not an option (Min. Leach)/ opponents want to hang on to the status quo (Premier)

- this is an attack on the government's entire agenda (Min. Leach)

- the megacity is part of an inevitable evolution (Min. Leach)

Good for economic development

- it's about economic development and an Ontario that is competitive, strong and has international presence in the world market / we will build a new Toronto to propel us into the future (Min. Leach)

- it will create jobs and enhance Toronto's competitiveness (Min. Leach)

- it will protect the core of Toronto and make it stronger/it is essential for Toronto to be strong and vibrant and that it lead (Premier)

Doing better for less

- it will be a simpler, less confusing system of local government/one cost-conscious, accountable government (Min. Leach)

- we can take advantage of the best ideas in government innovation and planning (Min. Leach) - it will lead to reductions in property taxes (Premier)

\section{Turf fighting}

- the mayors are fighting for their own turf and their own jobs at the expense of taxpayers and citizens (Min. Leach)

Message categories are in descending order of prominence.

Sources: Speeches, news releases and communications plans, Ministry of Municipal Affairs and Housing (Ontario); Globe \& Mail, Toronto Star and Toronto Sun.
Listening to people

- we will have to demonstrate that we are listening to the people's concerns (Premier) - we're going to take time to get it right (Premier) 
Table 21

Challenger Messages on the Megacity

Intended

Quality of life

- megacity is a threat to our quality of life

- it forces two urban lifestyles into one jurisdiction

Threat to local govemment/democracy

- megacity is a threat to local democracy

- it creates bigger, more distant government

Bill is undemocratic

- the process is undemocratic

- the government wants to shut down public

debate

- the government has slashed democracy in all the legislation it has rushed through

Amalgamation will cost money

- amalgamation will cost more
Message categories are in descending order of prominence.

Sources: Boudreau (2000); C4LD newsletters; Globe \& Mail, Toronto Star and Toronto Sun.
Actual

Assault on democracy

- this is not in the tradition of democracy in

Ontario/it's an assault on democracy (citizens)

- government is taking away elected councils and replacing them with people who will do their bidding (Sewell)

- this is dishonourable and wicked/it is tyranny, totalitarian and dictatorial (Sewell)

Process is undemocratic

- government is being arbitrary in trying to ram through the legislation without consultation (citizen) - government has made the public the enemy (citizen)

- restore democracy in Ontario (Citizens for Local Democracy)

- the government should consult before legislation, not after (citizen)

Megacity ends local democracy

- wiping out democracy in cities isn't consistent with the spirit of the constitution (lawyer)

- we will lose our local communities (citizens)

Too much, too fast

- show flexibility and slow down (metro councillor)

- do it right because you can't turn the clock back

(Mayor Nunciata)

- the bill goes too far (Liberal leader McGuinty)

- what's the rush (citizens)

- we need more details and more time (Mayor Lastman, citizens)

Not smaller and more efficient, but larger - it will lead to higher taxes and cuts to local services and programs (McGuinty)

Need more details

- the government needs to make the case for amalgamation and hasn't (Mayor Hall)

- government has no business case, no facts, no data to support its claims (Mayor Faubert)

Amalgamation chaos and impacts

- it's a prescription for privatization and layoffs (Darcy, CUPE))

- the chaos will mean less investment (Mayor Hall)

- it will destroy Toronto (Mayor Hali)

Govemment has to listen

- the government will have to take the referendum vote into account (Mayor Hall)

- government is dismissive of those who disagree (citizen) 
liberal restructuring: a unified Toronto would be streamlined, more efficient, accountable and good for investment. The unspoken but implied message was the fiscal crisis that required immediate and decisive action by government to keep it under control. Messages as actually covered in the media tended instead to focus on government inflexibility in moving its ideological agenda forward, which indicates the strength of the counter-hegemonic messages of the opposition. The investment messaging was prominent in announcement situations where the lead minister, $\mathrm{Al}$ Leach, could deliver messages in speaking notes. The message of improving local government was lost in the challenger messages, which were directly aimed at the threat to local democracy and for which the government did not seem to have a response. After the hearings and referenda, it became clear to the public and, through it, in the media that the hard-line message of moving ahead without taking the opinion of the public into account reflected the government's actual ideological position. Premier Harris, for instance, when commenting prior to the referenda about their possible outcome, said “it doesn't matter really" (Spears, 1997:A1). Only after this discounting of public opinion became an issue did the government add a "we're listening" message (MMAH, 1997e; 1997g). As in the OPSEU strike, Premier Harris communicated a more aggressive message, but this time there was no Dave Johnson to mitigate it; Minister Leach's quotes indicated just as strong a message as the Premier's. Just prior to the referendum, Premier Harris said "we're in a mess because we had governments for the last period of time that didn't have the courage to make decisions" (Ruryk \& Wallace, 1997:4). 
The challenger messages (see Table 21) focused on the threat to local democracy posed by amalgamation, particularly the undemocratic process that marginalized public input and moved swiftly to a pre-ordained goal. The actual messages as reported in the media were more diverse and less cohesive. They reflected two complicating factors in the substantial and growing opposition. First, the democracy message was broad, elusive and required interpretation by its messengers, which resulted in many different and personalized messages. The profusion of messages added another layer of complexity to an already complicated issue. No less than 15 citizens' groups were formed to fight amalgamation, each with messages that relied on those of the major oppositional actors and many with their own personalized point of view. ${ }^{28}$ Once, the rhetoric of C4LD's John Sewell became a target in media accounts. At times, Sewell said he believed Minister Leach was "setting up a dictatorial regime" (Blizzard, 1997:2). Another time, he suggested that Toronto should secede from Ontario if the government did not respect the outcome of the referenda (Ross \& Abbate, 1997:A3). Yet his speeches drew huge crowds to C4LD's Monday night's meeting week after week. Clearly, there was a disconnect between those citizens who looked to Sewell for leadership and those who were either deciding public policy or reporting on it. At one point late in the Megacity story, Minister Leach called Sewell a "paranoid" who "looks for deep plots in everything" (Wright, 1997:A9).

\footnotetext{
28 Some groups, such as Young C4LD and York Citizens for Local Democracy, had obvious antecedents and could draw on messages and other resources. Others had a different focus entirely, such as Artists Action Coalition and Architects for Urban Values. One group, Citizens' Legal Challenge to the Megacity, focused on the legal aspects of the issue. Still other groups, such as Save Our Scarborough, Etobicoke Takes A Stand and Save Our City Committee, had a more localized and contingent quality to their efforts. All these groups received media coverage in at least one of the three Toronto newspapers. Only one pro-amalgamation group, Alliance for Amalgamation, was formed late in the evolution of the issue.
} 
Second, authoritative challenger actors such as the mayors and influential oppositional public actors such as C4LD had different messaging, the mayors concentrating more practically on the lack of details and the speed of the initiative (Josey, 1997:SC1; Girard, 1997:A8), and C4LD focusing on democracy and the democratic process (DeMara, 1997:A10). As reported in the media, the two message sets were not integrated and cohesive. This brings Table 16 into focus, as the media coverage reflected the lack of cohesion in following a story that had many potential focal points and many actors. As C4LD and other challengers became more prominent actors, the media frame also adjusted, but at different speeds and in different ways, depending on the media outlet. When Table 21 is examined together with Table 14, a picture of an issue with multiple authoritative actors, both dominant and alternative, emerges. Although some of the editorializing in the Star and Sun seemed to indicate that C4LD had reached beyond the limits of social acceptability, no truly oppositional (as opposed to alternative) actors are cited in any of these stories. The lone possible exception-provided without context or explanation-is two references in the Sun to "a small group carrying a banner" which "disrupted" a speech by Minister Leach (Benzie, 1997:18; Ruryk, 1997:4). The second reference names the group (Toronto Coalition against Homelessness) and describes the disrupters as "anti-poverty activists" (4).

\section{Public Opinion}

Public opinion research was conducted on municipal restructuring by the government prior to the Megacity announcement but after the Premier's Office leaked the preferred reform option to the media (Ibbitson, 1997:248). The survey showed high awareness of 
the issue, but divided support (Ipsos-Reid, 1996f). Almost two-thirds (63\%) of those polled thought the current system of government was "just fine and should be left as is" (1996f). After the poll provided more information, it was able to 'push' opinion so that $58 \%$ (instead of $37 \%$ ) eventually agreed that amalgamation was supportable. The tenuousness of this result was amply illustrated after amalgamation was announced and support quickly declined. By the end of February, between $59 \%$ and $68 \%$ opposed the initiative, depending on which of three polls were cited (Benzie, 1997:2; Spiers, 1997:A1; Wanagas, 1997:7). Many of those polled believed the Megacity was the single most important issue facing the region (Moloney, 1997:A9). The surveys themselves were sponsored by the Sun/CFRB, the Star and the municipalities. ${ }^{29}$ The Star poll identified the possibility of increased taxation as the driver of antiamalgamation opinion (Spiers, 1997:A1), while the Sun poll cited the speed and the lack of consultation (Benzie, 1997:2). This is a reversal of the traditional perception of the Star as the 'progressive' paper representing the 'metro' perspective and the Sun as the paper normally concerned with issues affecting the taxpayer. Again contributing to the lack of cohesion in the opposition to the Megacity that was also reflected in the media, the poll sponsored by the municipalities cited other factors in anti-amalgamation opinion, such as a lack of accessibility to politicians and less protection for neighbourhoods (Moloney, 1997:A9). On the eve of the referenda, 80\% of those polled by the Sun said there needed to be more time to consult and study the changes (Benzie, 1997:2).

\footnotetext{
29 Ipsos-Reid conducted the Sun/CFRB poll, while The Strategic Counsel conducted the Star poll and Environics conducted the poll commissioned by the municipalities. All three are major Canadian public opinion research firms and Ipsos-Reid conducted much of the government's polling during the 1995-1997 period.
} 
Given the rise of media coverage during the consultations phase in which the referenda took place and the perception within coverage of a concomitant rise in activity surrounding the issue in the public sphere, it would be expected that there would be a continued rise in the polls in opinion against the Megacity. When taken together, the gap in opposition shown in the three polls is larger than the margins of error cited for them and the highest anti-Megacity results were followed by two separate polls which showed lower results. ${ }^{30}$ This leads-cautiously, since this is a limited content analysis - to the conclusion that the amalgamation issue peaked in late February and was already losing salience with the public before the referenda took place. Despite this signal early in the consultation phase, a high level of media coverage continued. This in turn suggests that the media drove coverage in this phase. Although the government continued to commission surveys (Bricker, 2002), no polls were published after the referenda to provide a comparison and to test this conclusion. It does, however, provide another explanation for diminishing media coverage in the final phase of the issue (see Table 15), despite the newsworthy filibuster conducted by the partisan political opposition. Together with the expected lower coverage in the amendment phase of a policy/legislative cycle and a focus on partisan actors, which is confirmed in this case study, the issue had lost salience with the public.

\footnotetext{
30 The results of the polls were reported differently than examined here, due to differences in reporting on public opinion research. The Environics poll sponsored by the municipalities and cited in both the Star and the Sun on 27 February did not report undecided respondents, while the other polls did. This inflated the anti-Megacity finding in the Environics poll to $68 \%$. In order to compare the polls, the results all had to be recalculated to exclude the undecided. Thus, Star readers actually read that anti-Megacity opinion moved from $68 \%$ to $48 \%$ (instead of from $68 \%$ to $58 \%$ ) and the Sun's readers read that opposition opinion went from $68 \%$ to $59 \%$ (instead of from $68 \%$ to $62 \%$ ). As reported, this suggests a sharper drop in opposition relayed to readers just prior to the vote. The Globe only reported the $68 \%$ figure (Globe, 27 February 1997) and followed it with a report on a poll commissioned by the Toronto Board of Trade of its members that showed 65\% support for amalgamation (Globe, 3 March 1997).
} 
Liz Rykert confirms that the campaign against amalgamation lost steam when it became clear that the struggle to change the government's direction had failed (Rykert, 2003): "People weren't being believed or listened to. We lost. People felt that. We knew we didn't have influence". After the referenda, there was "no tolerance" for a fight to reverse amalgamation (Rykert, 2002).

\section{Conclusion}

Amalgamation had both political and ideological benefits for the government. Politically, it was a strategy to minimize vocal opposition to the government by reducing its locus of influence-municipal politics (Ibbitson, 1997:257). Amalgamation as a specific option to ameliorate local government was not a recommendation in any of the many government-commissioned reports on local government and Toronto-related issues over the previous 30 years, but was chosen by this government at this time to fulfill its political needs (Boudreau, 2000:7). The "taming" of Toronto liberal-left politics created space for economic development to proceed (169) while allowing the government to demonstrate that it could keep its election promise of rationalizing government operations. Ideologically, amalgamation signaled to business interests led by the Toronto Board of Trade (Todd, 1998:206-7) that it was committed to its neo-liberal agenda. It also enabled the government to remove jurisdictional barriers preventing Toronto from becoming a global city on the leading edge of globalization (211; Boudreau, 2000:3).

Like the OPSEU strike, the Megacity issue is another symbolic battle- 
a story of the old paradigm confronting the new. But where the OPSEU strike invoked stereotypes of labour conflict in both the old and new worlds, the emerging paradigm led by the government showed itself to be unprepared for debate and opposition conducted on unfamiliar terrain — public space—and on an unfamiliar themedemocracy. Government messages, both intended and actual, show that the government did not initially identify the potential or later acknowledge the actual strength of the public discourse surrounding democracy (see Table 21). Only a weak "we're listening" message emerged, perhaps as much a response to the concerns of Conservative backbenchers as it was directed at the public, ${ }^{31}$ but the message was dissonant with the government's actions of moving ahead on its agenda.

The lack of message coherence was not unique to the government side of the legislature. The two other partisan actors, the Liberals and the NDP, took different stands on the issue. Although both parties were against the Megacity, the Liberals favoured a one-year delay in the implementation of the bill, while the NDP wanted the bill withdrawn (Ibbitson, 1997:267). The media tended to report both partisan oppositional positions briefly, which emphasized division between them instead of their mutual opposition to government. Successes of other challenger efforts were also dissipated by their lack of coherence. Although the C4LD position of a threatened local democracy was clearly evident in the media, so was the more scattered message set of the municipalities, which focused on excessive government speed and insufficient consultation. As has been suggested in the content analysis, media coverage reflected this confusion of messages, particularly in the consultations phase of the issue.

31 Those Conservative backbenchers who had indicated they might vote with the Liberals and New Democrats against the government in the end did not (Urquhart, 1997a:A25). 
Although primary definition by authoritative actors (both for and against amalgamation) in the media coverage is clearly established, its benefits are muted by the profusion of actors and their mixed, if not contradictory, positions.

At the root of the lack of challenger coherence lies a conflict between alternative and oppositional meaning systems (Williams, 1977). Boudreau (2000:58) writes that C4LD's tactics comprised both radical actions and traditional lobbying in a "tension" that was "a major strength of the movement". Describing this interrelationship also as existing between "insurgent" and "institutional politics" (126), Boudreau is also describing oppositional and alternative meaning systems. The tension between the two was a creative feature of C4LD's success while in campaign mode against amalgamation, but it can also partially account for its later failure to extend and build its movement after the bill was passed. Insurgency as oppositional politics is by definition unpredictable, anti-systemic and, often, unsustainable. Its tactics and messages thus are concerned with changing or removing a hegemony, not reforming or influencing one, as an alternative challenge might. Despite the creative interruption of its tactics, C4LD's goal was not disruption of the hegemony. Boudreau (2000) points out that C4LD's "Values Statement" highlights compassion, faimess, respect and accessibility, placing "its strong emphasis on action by political pressures in order to influence public policy, rather than calling for alternative lifestyle, civil disobedience, metropolitan strikes, or communal solidarity" (57).

Municipal challengers, not surprisingly as representatives of a tier of government, similarly espoused alternative positions. They urged the provincial government to allow more time and to give more detail of their plan for the Megacity, 
but they did not reject the plan outright or question the government's legitimacy. Those municipal representatives who disagreed with the position taken to oppose the Megacity did not do so in order to engage in more radical politics, but to agree with the dominant position put forth by the provincial government.

Once the 'campaign' to stop the Megacity was over, C4LD faced internal struggle and debate about its future direction (Boudreau, 2000:18, 28). Noel (1997) writes that C4LD's "all or nothing strategy" was aimed at "political surrender" of the government, which failed (6). As Rykert said, supporters keenly felt they had lost, most went back to their daily lives and C4LD ultimately disbanded (Rykert, 2003). A protracted debate on whether to endorse candidates in the fall 1997 municipal election was divisive (Boudreau, 2000:69); as often happens in issue-based organizations with mixed alternative and oppositional membership, state elections - the key element in a parliamentary process that "drags parties away from movements" (Bleyer, 1992:113114)-make visible the fundamental cleavage between two irreconcilable perspectives on the 'system' (Robinson, 1996:65).

C4LD's way of handling the division between those who rejected the label "radical", as they were sometimes characterized by the government and the media, and who identified themselves as "citizens" was to encourage supporters "to operate at a level they felt comfortable at" (Sewell in Boudreau, 2000:59). This openness was disadvantageous, however, when C4LD attempted to expand its movement beyond Toronto. Its lack of hierarchy and informality worked successfully when in campaign mode, but it had not developed the "connective structure" (Tarrow, 1998:23) internally or with other movements that it needed to continue and develop. As with many of the 
new movements, C4LD was tolerant of a wide variety of beliefs, but lacked a coherent ideological project or ideological principles that might have allowed it to move forward more cohesively (Offe, 1985b:817).

Others have discussed the limited nature and appeal of the anti-democracy movement in terms of class analysis. The "action space" referred to by Boudreau (2000:57) is also understood by her to be middle-class action space. Keil (1998) contends that C4LD failed to extend its base to working class and visible minority populations: "The middle-class discourse of citizenship and local democracy has its own characteristic blind spots: social justice and difference... It has not made the leap to an urban social movement capable of changing the meaning of the city" (161). Antiamalgamation forces, which comprised mainly "the voice of the self-interested professional class in the inner city" (Isin, 1998:182), did not bridge the ideological distance between themselves and their suburban middle class counterparts. ${ }^{32}$ The government did not need to conduct a 'divide and conquer' strategy within the Toronto area, as citizens were already divided. C4LD's "liberal grammar of politics that invoked 'democracy', 'due process', 'citizenship' and 'public good”' did not appeal to a suburban middle class whose real wages had declined in the previous decade (184, 186). As the referenda results show, participation was highest in the downtown and urban areas (ranging between $38.6 \%$ and $41.1 \%$ ) and lowest in the suburbs (between $18.5 \%$ and 19.4\%) (Boudreau, 2000:15). It becomes clear that the 'public' in media coverage is drawn from a more narrow stratum of Toronto society-not just middle class, but the white urban middle class-and that their message sets and tactics

\footnotetext{
32 Isin profiles the citizens in the suburban belt around Toronto as "groups made up of immigrants, refugees, the working poor, non-unionized and low-income service workers and tradesmen (184).
} 
reflected, in effect, "an old style of politics for newly emerging realities" (Isin, 1998:186).

Citizens for Local Democracy mounted one of "the most effective and large scale political mobilizing campaigns in the recent history of Toronto" (Keil, 1998:160). Through its extensive and sophisticated electronic communication systems in particular, it "explored new forms of resistance and political organization" (Schmid, 1998:146). For a time, it "swept to the background concerns about competitiveness, streamlining, and global city formation" (Boudreau, 2000:58). This discursive success challenged the government's high-level efficiency rhetoric through the force of lived experience, with the urban middle class bringing its own common sense to bear on the Common Sense Revolution.

Although it did not meet its goal of influencing policy on the issue of amalgamation, it did meet its other goal of influencing civil society (Boudreau, 2000:59), although only temporarily. It mobilized the non-political middle class in an "alternative social project at the local-regional level that connects multiple scales of social interaction" (Schmid, 1998:146), but then, as Rykert has said, supporters returned to their daily lives. The dissipation of the movement could only have reinforced the government's belief (and messaging) that such challenges to their policies were conducted in the self-interest of those involved.

In the Megacity debate, the government continued to follow its undiluted neoliberal agenda, despite the contestation and resistance it faced in the first 18 months of its mandate. Although the government's lack of coherence on a complicated issue contributed to the strength of the resistance against it, the complex matrix of challengers 
similarly did not speak with one voice. By choosing an amalgamation option over the recommendations on regional governance from the many reports at its disposal and by not listening to public concerns about the content and process of its initiative, the government signalled its political and ideological commitment to its agenda: "That the government felt compelled to act against the wishes of the huge majority of the voters in a local referendum and did not address the regional governance concerns identified in [the Golden report]--suggests that the downsizing of public government was what drove the agenda" (Todd, 1998:213). The government also demonstrated, as it had throughout its time in office, that it was not interested in the gaining of consensus that had concerned previous governments grappling with municipal reform (Ibbitson, 1997:246). The making of the Common Sense Revolution platform gave the government its issue and message set and the election gave it its mandate. From its lack of preparedness for resistance, the government demonstrated that the implementation phase of its neo-liberal agenda relied mainly on a blitzkrieg strategy of a quick policy thrust on several fronts simultaneously (Easton 1989b) and did not include a full communications strategy.

The citizens' movement represented by $\mathrm{C} 4 \mathrm{LD}$, although working separately from other opposition to the government, reinforced and intensified the 16 months of resistance that led up to the amalgamation battle. As with the OPSEU strike, labour and social justice group-led Days of Action bookended the Megacity debate with actions taking place on October 25-26 in Toronto and on April 28 in Thunder Bay. The growth and proliferation of these actions illustrate the tenuous nature of the fledgling project as it emerged, although it was debatable how far the actions had penetrated into the 
broader public beyond opposition that was already organized. Media coverage still tended to be localized to the venue and time of the action, and little context or connection was made between actions, although by this time the actions (now numbering six) were seen to be building towards an eventual Ontario-wide action (Munro, 1997). 
Case Study 3: The Education Quality Improvement Act and the Teachers' Strike

\section{Introduction}

The third case study picks up five months after the passage of Bill 103 on amalgamation. The post-Megacity public environment was busy for both the government, with a continued slate of legislative initiatives that included more restrictive labour legislation, and organized resistance, with an additional Day of Action organized in April in Thunder Bay and another action scheduled for North Bay in September.

Two surveys conducted by Ipsos-Reid for the government during this time show a continued public concern for the quick pace at which the government was reducing the provincial deficit (1997c:7). Despite a belief that the government's spring 1997 budget would improve the economy, there was significant concern about the future of health care and education $(3,8)$. When asked about their feelings on the possibility of a strike- both public sector workers and teachers were mentioned as possible strikersthe public was cautious and divided. They also responded less positively to messaging the government had used in its previous strike encounter with OPSEU (3-5)!

Bill 160, the Education Quality of Improvement Act, received first reading in the legislature on September 22, 1997. Although education was not listed for cutbacks in the Common Sense Revolution, the government signalled early in its mandate that it planned to restructure the Ontario school system. From the government's first round of expenditure cuts just after it came to power, education governance and funding were the 
Figure 22

Chronology: The Education Quality Improvement Act (Bill 160)

September 11, 1997 Education Improvement Commission's first formal report, The Road Ahead: a report on learning time, class size and staffing, is released

September 22, 1997 Bill 160, The Education Quality Improvement Act, is introduced

September 26-27, 1997 North Bay Days of Action

October 6, 1997 Teachers hold mass rally at Maple Leaf Gardens in Toronto

October 10, 1997 Premier Mike Harris shuffles his cabinet and replaces John Snobelen with Dave Johnson as Minister of Education and Training

October 17, $1997 \quad$ Windsor Day of Action

October 21, 1997 NDP releases leaks document showing the government's intent to make more cuts to education

October 22, 1997 Premier Harris makes television address to Ontarians on the first of six days of Ontario-wide hearings on Bill 160 to say that the government is going to honour its commitment to improve the education system and put Ontario's children first

October $271997 \quad$ Teachers begin walkout

October 31, 1997 Minister Johnson receives the first benchmark standardized testing results from its Education and Accountability Office and indicates that a lot of improvement is required because not enough students are meeting the standards

November 3, 1997 Ontario Court decision on the government's injunction rules that no irreparable harm has been caused and speaks well of the teachers' motives

November 5, 1997 Bill 160 amendments are tabled

November 10, 1997 Teachers go back to work on Ontario municipal election day

November 13, 1997 Minister of Education tables amendment to Bill 160 that removes principals and vice-principals from the bargaining unit

December 1, 1997 Bill 160 passes and receives Royal Assent

January 1, $1998 \quad$ Amalgamation comes into effect

May 1-October 25,1998 Days of Action continue in St. Catharine's, Kingston and Ottawa

June 6, $1999 \quad$ Progressive Conservative government re-elected 
object of government moving "at warp speed... attacking on all fronts in rapid succession" (Paquette, 1998:13). This included: cuts to the Ministry of Education budget, reduced transfers to school boards, a 'savings strategy' for school boards, repeal of the Employment Equity Act which had an impact on school board hiring, phased-in abolition of Grade 13, creation of a College of Teachers to regulate, certify and test teachers, creation of the Education Quality and Accountability Office with responsibility for standardized provincial testing, overhaul of secondary education, announcement of a complete new curriculum for all students (kindergarten to Grade 13), and introduction of a standardized report card (3-16).

All this activity was initiated before Megaweek in January 1997, at which point the government announced the first part of its restructuring of education finance and governance in a reform package that included Bill 104, the Fewer School Boards Act. Although teacher unions, school boards and parents organized against Bill 104, particularly at the hearings, and expected the bill would be amended, it was part of a deal by all three parties to allow the government to pass it without a single amendment in return for concessions on amendments to the Megacity bill. ${ }^{33}$

As with the OPSEU response to public sector restructuring, the reaction to Bill 160 involved a strike; as with the Megacity issue, it involved a controversial piece of neo-liberal legislation. The Bill 160 case brings together the blitzkrieg campaign

${ }^{33}$ Concerns about the bill included criticism of the large size, both geographically and in number of students, of the new district school boards and of the government's contention that fewer school boards would result in higher education standards (MEdT, 1997e; Flynn-Turner, 1997:D5). Concerns were also expressed at the "unprecedented powers... something close to the exercise of unscrutinized dictatorial powers" allowed the Education Improvement Commission, established in Bill 104 to oversee educational restructuring (Paquette, 1998: 19). A later Charter challenge by school boards of Bill 104 was not upheld, although the Ontario Court of Justice expressed deep concern at the use of executive authority in a clause that placed regulation above statutes (Dickinson, 1998:434). 
approach and the crisis construction, the latter in a more visible and clearly stated way than used previously by the government when Education Minister John Snobelen said six times in a speech to a meeting of education ministry senior employees that education reform would be predicated on an artificial crisis in public confidence in the education system to be created by the government (Cohen \& Greaves, 2001:131):

Creating a useful crisis is part of what this will be about. So the first communications that the public might hear might be more negative than I would be inclined to talk about (otherwise)... Yeah, we need to invent a crisis, and that's not an act of courage, there's some skill involved (Brennan, 1997:A3).

(The Minister's comments were leaked to the Star.) Like the deficit before neoliberalism focused the public's attention on an artificially constructed crisis, the state of public education was not a public issue prior to the government's coming to power. Regular biennial surveys conducted by the Ontario Institute for Studies in Education showed Ontarians were increasingly satisfied with the quality of education. ${ }^{34}$

The main thrust of Bill 160 was to discipline labour and education finance. It revised the Education Act to include teacher work conditions formerly decided in teacher-school board contract negotiations and it removed principals and vice-principals from the bargaining unit (Paquette, 1998:23-4). It centralized control of the major cost and spending elements in education and removed the ability of school boards to raise local taxes to fund budgets, which needed to go to the newly formed Education Improvement Commission for approval. The bill also gave Cabinet the right to make

34 Satisfaction with public education dropped only in the 1998 survey, after the Bill 104 and Bill 160 restructuring (OISE, 1996; OISE, 1998). 
decisions concerning education through unilateral regulation rather than through democratic legislative processes.

\section{Government Communication Strategy}

The government's strategy for Bill 160 was more refined and detailed than in the previous two case studies. Prior to the announcement, it had made concessions on several different issues to 'clear the deck' in order to minimize other opposition and concentrate on education reform. ${ }^{35}$ Despite the breadth of the bill, the government announced only six days of hearings. In contrast to the five weeks of hearings on the Megacity, which allowed opposition to build against the initiative, the government thus revealed that its strategy was to control opposition comment.

The government's strategy for Bill 160 relied heavily on the self-interest frame usually employed in media coverage of industrial disputes (Knight, 1982; Ryan, 1991). The media echoed the self-interest frame used by the government to frame the teachers' walkout. The government tried to create a picture of big labour opposed to change and compromise, while the government was working in the interest of all Ontarians by keeping costs (and the deficit) under control: "We all have to put our own personal interests aside for the sake of our students" (MEdT, 1997d).

It also positioned itself as the defender of quality education in its strategy to "focus communications on the government quality agenda, which includes curriculum, standards and testing" in order to "achieve its goal of providing the highest level of

35 The Globe \& Mail reports this as "a sharp shift in strategy" and ties the concessions to preparation for the next election. Among other issues, concessions were made on the timing of closing hospitals and on proposed limits to the right to strike (Mackie, 1997: A1). 
student achievement in the most cost-effective manner" (MEdT, 1997c:1). The goal of quality education as put forward by the government is clearly limited by the amount of funding available. In addition, the government signaled its commitment to ideological coherence against any anticipated opposition through its repeated message:

“Government is flexible about reaching its objectives, but will not compromise its goals" (MEdT, 1997c).

The government's strategy included using institutionalized sources to provide credibility for its position through third-party testimony. The first report by the Education Improvement Commission (EIC), created by the government though Bill 104 earlier in the year to study and make recommendations on education reform, was released 11 days before the introduction of Bill 160. "We will be looking closely at the recommendations... I look forward to hearing more about the many good ideas that are in this report", said Minister Snobelen in a press release (MEdT, 1997f). Many of the EIC's recommendations were included in the bill. In fact, the government's communications strategy for Bill 160 formulated tactics based on "proposed recommendations expected from the EIC report" (MEdT, 1997c). The Ontario Parent Council (OPC), established by the previous government to provide a parent voice to the government and comprising $50 \%$ government appointees, was cited by the government as supportive of its position to remove principals and vice-principals from union membership (MEdT, 1997d:2). The Education Quality and Accountability Office (EQAO), a 'quango'36 formed by the government to develop and implement its

\footnotetext{
${ }^{36}$ A quango is a "quasi-autonomous non-governmental organization", which is a type of organization promoted by neo-liberal governments, often to undertake work previously conducted within the public sector (Paquette, 1998:14; Deacon \& Monk, 2000:45). The EIC, ironically, is a non-accountable body formed by the government to enhance perceptions of accountability.
} 
standardized testing programs, made its first report during the teacher walkout. The report, which stated that not enough Ontario students were meeting the standards set by the EQAO a year previously, was intended to bolster the government's claim that the quality of education in Ontario needed radical improvement.

The government showed once again that it would use the courts to keep its agenda moving forward in the face of labour or public intransigence. Two days after the teachers began what they called a "political protest", the government called an "illegal strike" and the media for the most part referred to simply as a "strike", the government requested an injunction to have the teachers return to work, citing irreparable harm to students. Unlike in the OPSEU strike, where it did not want to appear to be using force unreasonably to end the conflict, the government was clear that it would use 'back-to-work' legislation if necessary (Harder, 1997:4).

A further strategy was to be available to the media, but also to reach the public more directly through a televised message from the Premier (MEdT, 1997a:1-2). In a development not seen in the previous case studies, the government developed a 'communications support team' to ensure coordinated actions and consistent messages (MEdT, 1997a). ${ }^{37}$

\section{Challengers and their Communication Strategies}

Formal partisan opposition to the bill by the Liberals and the New Democratic Party was slow to formulate. Deacon and Golding (1994) have written that the parliamentary

\footnotetext{
37 It is not possible to know for certain what the government's internal plans were for the OPSEU strike, due to the exemption of this material from FOIPPA legislation, but all reports point to the government's lack of preparedness for sustained opposition, much like the other case studies.
} 
process leads media coverage, thereby providing public information. They further write that "if an issue is marginalized by the main political parties, it is highly unlikely to attract consistent attention in the media" (182). The partisan opposition, particularly the New Democratic Party, ended up playing a key role. Unlike the Megacity debates, the legislature was in session during the Bill 160 issue, giving the partisan opposition more visibility and scope to develop.

Beyond the political parties, the five Ontario teachers' unions mobilized quickly against the bill, under their umbrella organization, the Ontario Teachers' Federation $(\mathrm{OTF}){ }^{38}$ The OTF had anticipated restructuring in the educational sector under the new government and had been strategizing since January 1996. Their polling confirmed that their greatest communications advantage was teachers themselves and they built a strategy around that finding (OTF, 1998). The OTF strategy entailed getting the support of its membership, a group of 126,000 teachers not used to thinking of themselves as part of organized labour. ${ }^{39}$ The OTF communications strategy countered the expected government and media framing in two ways. First, when the government attacked union bosses, "we gave them Eileen Lennon, everyone's grade 3 teacher". ${ }^{40}$ Second, the OTF tried to shift the media frame from the self-interest frame to the alternative labour frame of justice (Ryan, 1991) with the message that "teachers are fighting to protect publicly funded education for our students" (OTF, 1998).

\footnotetext{
${ }^{38}$ The five teachers' federations are: Ontario Secondary School Teachers' Federation, Federation of Women Teachers' Associations of Ontario, Ontario English Catholic Teachers Association, Ontario Public School Teachers Federation and Association des Enseignant/e/s de l'Ontario.

${ }_{39}$ As white-collar professionals, teachers' unions were slow to join 'the house of labour', the Canadian Labour Congress, with its record of industrial militancy, only doing so in 1999.

${ }_{40}$ Eileen Lennon, an elementary school teacher, was OTF president at the time of the walkout.
} 
Key messages in the plan also challenged the usual self-interest frame (Ryan, 1991) and inconvenience/effects frame (Knight, 1982) used in industrial conflicts and emphasized that "this is about students in the classroom". Their print advertising campaign highlighted the "crisis in the classroom" and their belief that the government was "moving too far, too fast". The strategy further targeted Minister Snobelen personally. Television advertising featured an out-of-control car and the personalized message: “Where are you taking us, Mr. Snobelen?" (OTF, 1998).

As with the Megacity debate, a public tier of organized opposition to the government emerged to counter education restructuring. Because the government had long signaled its intent to restructure, two main groups representing the two major positions taken by parents/public had already been in operation for a year and had been active in opposing Bill 104. People for Education (P4E) is a Toronto-based parents' group that formed in late 1996 to oppose cuts to education funding and the Ontario Education Alliance (OEA) is similarly Toronto-based and formed early in the government's mandate. ${ }^{41}$ In the alternative and oppositional meaning systems put forward by Williams (1977), P4E is an alternative group; it seeks change or reform, but within the system. The OEA is an oppositional movement, its ultimate aim to create a new vision for education to lead to a new polity in Ontario (OEA, 1996). Its long-term goals include progressive educational reform, an electoral strategy to defeat the government and the repeal of Bill 160. Over time, P4E has become more institutionalized and authoritative as the 'voice of parents', providing commentary to

\footnotetext{
41 As with the Megacity opposition, many local groups formed to oppose the government's education restructuring. They included: Metro Parents Network, Stop Bill 160 Committee (Guelph), People Against Cuts to Education (Kitchener-Waterloo), Public Education Rights Coalition (London), Mothers and Fathers for Education (Thunder Bay), Simcoe Parents' Information Group, Coalition for Public Education (Ottawa) and at least 13 other groups across Ontario.
} 
media and appearing at (and organizing) education conferences for parents, while the OEA operates passively and has a presence in academic and progressive spheres. The two groups provide a contrast in style and substance that reflected the division among parents and the public on the position to take to respond to the restructuring-either that the government was going 'too far, too fast' and only needed to slow down, or that it was destroying public education and needed to be stopped. This difference becomes significant at the end of the Bill 160 story, when decisions were made as to how or if to continue opposing the government.

As an alternative group attempting to again access to the media, People for Education has had considerable success. Annie Kidder, one of P4E's founders, felt the novelty of parents organizing made their work appealing to the media, even though they sometimes had to use "stunts" to ensure coverage, recognizing the conundrum of also wanting to be taken seriously (Kidder, 2003). Kidder told the Globe: "We spend all our time staging little dramas for the press so we'll get a chance to explain to them afterward what we're worried about. It's a weird game" (Salutin, 1997:C1). With experience and a growing body of research, says Kidder, the media know they can rely on P4E for informed comment- "our facts are really solid"- and they have no need to resort to the 'concerned mom' images that brought them coverage previously (2003). The Ontario Education Alliance's approach to media coverage was less traditional. As an oppositional group, it tended to "insert itself into the action", relying less on news releases and more on distributing flyers and showing up at government-sponsored hearings and demanding to be heard (Latter, 1998). Both groups were successful in obtaining media coverage, although sometimes the coverage was not credited to their 
organization but individualized to the person representing the group. Both groups tended to ad hoc communications strategies, as their resources were limited, and they often reacted to a government story rather than initiating their own news.

In terms of successfully organizing and accessing media, a strength in each group, and in another active challenger group, the Ottawa-based Coalition for Public Education, lay in their spokespersons. Kidder was an actor with strong connections in the cultural industries, an active sector politically against the government. Jacqueline Latter of the Ontario Education Alliance was appointed the first chair of the Ontario Parent Council by the previous NDP government. John Crump of the Coalition for Public Education was a policy and research analyst with a background in journalism. Each brought a strong and authoritative voice to their spokesperson roles that was based in knowledge and experience of politics and media. Credibility was allotted to them by journalists who shared the same schemes of understanding: middle class, little labour consciousness, well-educated and reflecting the same political orientation. As Ginsberg $(1986: 142,144)$ has said, the political views of mainstream journalists tend to reflect the views of their dominant, mainstream audiences and these views shift over time as audience views shift.

The teachers' campaign was reinforced by well-reported strategic errors by the government. Four days after the teachers held a mass rally attended by 20,000 in Toronto, Premier Harris shuffled his cabinet, removing John Snobelen, who was widely seen by media and public to have mishandled his education portfolio. It was characterized as a 'blink' in the government's 'hit hard, hit fast, don't blink' overall strategic direction. It was also seen by the union and the media as a victory for the 
teachers, whose ad campaign had been criticized for not capitalizing on their public standing instead of targeting Snobelen (OTF, 1998; Delacourt,1997:A1). Harris replaced Snobelen with Dave Johnson, who had been an effective spokesperson in the OPSEU strike.

Just before the teacher walkout, the New Democratic Party leaked government documents to the media that confirmed what the teachers had been saying and the government denying - that Bill 160 was about cuts to education, not the quality of education. The documents showed that $\$ 667$ million more cuts to education would take place. The leak weakened public trust in the government (Small, 1997a:A1) and played to its fears that the executive authority the government had given itself in Bill 160 was not well-placed or in the public interest. A day later, the government followed its plan and televised an address by Premier Harris that was intended to demonstrate the government's control of the agenda. Although the address was well-received and reported in the media, the leak began a slide in public opinion—an Ipsos-Reid public opinion poll confirmed that education was gaining strength daily as the most important issue facing Ontario (Delacourt, 1997:A1). A Toronto Star editorial (1997:E2) was headlined "Tory credibility on schools is shattered".

When the Ontario Court ruled against the government and did not grant the injunction to get the teachers back into the classroom, Mr. Justice James MacPherson also made a connection between the teachers' motives and the public interest: "The teachers have never engaged in a province-wide strike... They are deeply committed to the education of their students and they have behaved in an entirely peaceful fashion... When they point to the serious problems of Bill 160 they do so in the public interest" 
(Ontario Court, General Division, 1997). The leak, the court decision and the ensuing high-profile media coverage allowed the public to confirm the teachers' motives as advocating justice and helped the media to shift away from the industrial frame of selfinterest (Ryan, 1991). It also strengthened parent opposition: "Before the injunction decision, parents were divided about the walkout. They were somewhat sympathetic to the teachers, although they didn't quite understand what it was about", says John Crump, who was spokesperson for an Ottawa-based parents' group Coalition for Public Education. "After the denial [of the injunction], parents and school councils came out of the woodwork begging for information on Bill 160 and asking us, as fellow parents, to come and speak to them" (Crump, 1998). Jacqueline Latter of the Ontario Education Alliance also credits the injunction decision with contributing to a more supportive public environment: "As soon as the decision was brought down, the phone calls started" (Latter, 1998). Latter points out that parents and the public also played a role in the decision itself, through affidavits they submitted to the court and to which Mr. Justice MacPherson referred in his opening remarks and his judgement (1998).

\section{Media Coverage}

Media coverage of Bill 160 does not reflect the burgeoning public opposition. As Table 23 shows, the general public was not an important actor in overall media coverage. If the public is narrowed to only include those public actors and groups who have a stake in the teachers' strike, such as individual students and parents' groups, there is a range of coverage from $10.3 \%$ (in the Sun) to $17.2 \%$ (in the Star). In this regard, the Bill 160 coverage is similar to the Megacity coverage, in which segments of the public also had 
Table 23

\section{Political Actors in Mainstream Print Media Coverage \\ on Bill 160 (Education) \\ (September 22-December 2, 1997)}

by media outlet

by percentage

\begin{tabular}{lccc}
\hline $\begin{array}{l}\text { Actors } \\
\text { (1st reference only) }\end{array}$ & Globe \& Mail & Toronto Star & Toronto Sun \\
\hline & & & \\
\hline Party Political Actors & & & \\
Provincial government & & & \\
Premier \& lead ministers & 37.1 & 28.9 & 38.9 \\
Other Conservative politicians & 1.5 & 7 & 2.7 \\
Provincial political opposition & 5.9 & 7.5 & 6.2 \\
Provincial Speaker & 1.2 & 1.3 & 0.9 \\
Federal politicians & 0.0 & 0.6 & 0.0 \\
& & & \\
Non-Party Political Actors & & & \\
Unions & & & \\
Union leadership & 17.7 & 20.6 & 18.1 \\
Other unions & 1.5 & 1.5 & 2.2 \\
Individual teachers & 5.0 & 11.4 & 7.1 \\
Public actors \& groups & & & \\
Challengers (i.e. P4E) & 1.2 & 2.7 & 1.8 \\
Supporters & 0.0 & 1.0 & 1.8 \\
Individual parents & 5.6 & 7.3 & 2.7 \\
Individual students & 1.8 & 6.2 & 4.0 \\
Academics \& experts & 2 & 1.0 & 3.5 \\
Private sector/business & 0.9 & 0.0 & 0.0 \\
Lawyers/courts & 5 & 1.3 & 3.5 \\
General public/Misc. & 12.4 & 4.2 & 6.6 \\
& & & \\
\hline & & & \\
\hline Figus rolate to nows & & & \\
\hline
\end{tabular}

Figures relate to news items (only) which focused on Bill 160.

Figures refer to the first reference to the actor in the news item.

a strong voice, and dissimilar from the other labour dispute in these case studies, the

OPSEU strike, in which the general public did not have a voice. This inclusion of other points of view and other actors suggests that the more rigid and polarized frames and coverage usually found in strike coverage did not hold sway in this labour dispute involving teachers. This confirms the impression that the standard media frame of union self-interest faltered because it was not clear that teachers were either self- 
interested or unionists. Also different from the OPSEU coverage is the lack of police presence. Clearly, there was little expectation that teachers would resort to violence, further differentiating them from the standard perception of unionists on strike.

Table 24 shows that institutional party actors had a strong proportional presence in Bill 160 coverage (that is, when all references to an actor are counted rather

Table 24

Proportional Presence and Disposition of Political Actors in Mainstream Print Media Coverage on Bill 160 (Education) (September 22-December 1, 1997)

consolidated news coverage in Globe and Mail, Toronto Star and Toronto Sun by percentage

\begin{tabular}{llll}
\hline $\begin{array}{l}\text { Actors } \\
\text { (all references) }\end{array}$ & $\begin{array}{l}\text { Proportional } \\
\text { Presence } \\
\text { in all news items }\end{array}$ & Critical & Supportive
\end{tabular}

Party Political Actors

Provincial government

Premier \& lead ministers

Other Conservative politicians

Provincial political opposition

Provincial Speaker

Federal politicians

$\begin{array}{rrrr}45.2 & 0.0 & 100.0 & 0.0 \\ 2.5 & 35.6 & 49.2 & 15.3 \\ 9 & 100.0 & 0.0 & 0.0 \\ 1.3 & 0.0 & 0.0 & 100.0 \\ 0.3 & 16.7 & 83.3 & 0.0\end{array}$

\section{Non-Party Political Actors}

Unions

Union leadership

Other unions

18.1

0.9

99.1

100.0

0.9

0.0

Individual teachers

\section{9}

89.4

10.6

0.0

Public actors \& groups

Challengers (i.e. P4E)

1.5

0.8

100.0

66.7

0.0

0.0

Supporters
Individual parents

Individual students

3.8

61.5

27.8

0.0

3.3

65.4

15.4

Academics \& experts

Private sector/business

0.1

42.6

Figures relate to news items (only) which focused on Bill 160.

Proportional presence refers to the frequency of appearance of the actor in the news item with each reference counted. 
than the first reference only), with $52 \%$ of overall coverage. Once again, the pattern of which actors are present is different here than from the OPSEU case; here, party political actors have a stronger presence and the union a lesser presence, but public actors are present as well (9.4\%). Other Conservative politicians have less visibility in this case study than in the Megacity case, but more than one-third (35.6\%) of those who are cited are critical of their government. Eventually, two Conservative backbenchers would vote against their party on the bill (Girard, 1997:A1; Mackie, 1997:A8). Of the three case studies, the Megacity debate seems to have been the one that was the most internally problematic for the government. Public actors and groups also expressed a range of attitudes towards Bill 160 , but between $61.5 \%$ and $65.4 \%$ of those actor categories with mixed opinions (individual parents and students) were critical of the government's initiative. (Of those few groups that supported the government- $0.8 \%$ overall—much of their media citations actually could be interpreted as criticism of the government.)

As this case study includes a piece of legislation, it follows a more clearly defined phase pattern based on the policy cycle, as seen in Table 25. As with the phases in the Megacity case (see Table 15), the legislative process guides the phases: the first phase comprises the introduction of the legislation and the leak and ends with the beginning of the teachers' job action. The consultations occurred during the walkout, as does Justice MacPherson's ruling. The final phase returns to the legislature for amendments and passage of the bill. Media coverage for all three media outlets peaks in the middle phase, understandably since it contains, simultaneously, the consultations and the teachers' job action within it. The amount of coverage does not drop off as 
Table 25

\title{
Phases in Mainstream Print Media Coverage of Bill 160 (Education)
}

(September 22-December 2, 1997)

\author{
by media outlet \\ by number of news items \\ by number of news items per day (in brackets)
}

\begin{tabular}{lccc}
\hline Phase & Globe \& Mail & Toronto Star & Toronto Sun \\
\hline $\begin{array}{l}\text { Introduction of Legislation } \\
\text { September 22-October 26, 1997 } \\
\text { (34 days) }\end{array}$ & $19(0.6)$ & $26(0.8)$ & $21(0.6)$ \\
$\begin{array}{l}\text { Consultation \& Job Action (Strike) } \\
\text { October 27-November 9, 1997 } \\
\text { (13 days) }\end{array}$ & $18(1.4)$ & $30(2.3)$ & $16(1.2)$ \\
$\begin{array}{l}\text { Amendments \& Passage } \\
\text { November 10-December 2, 1997 } \\
\text { (22 days) }\end{array}$ & $11(0.5)$ & $20(0.9)$ & $11(0.5)$ \\
$\begin{array}{l}\text { Total items (items per day) } \\
\text { (69 days) }\end{array}$ & $48(0.7)$ & $76(1.1)$ & $48(0.7)$ \\
\hline
\end{tabular}

Percentages in each column may not add up to $100 \%$ due to rounding.

quickly as it did for the Megacity case, suggesting that the amendment phase, which is usually focused on the legislature, either was considered newsworthy in itself or that the issue retained its salience; the latter would be bad political news for the government.

As established by Fishman (1980) and as is evident in these case studies, there are logical phase patterns that are linked to everyday events. Deviance from the pattern can supply reinforcement for contentions that particular issues have public or media salience. It is often said that if political issues are not 'closed down' quickly, then the issue is lost. Sustained media interest in an issue is one indication of a 'hot' issue, but high coverage can also be normal for an issue in a particular phase of its storyline, such as a phase that includes public consultations. An issue that is enduring would have 
continued high media coverage in its last phase, rather than losing salience, as in these case studies. A last phase can be identified by the passage of a piece of legislation or a logical conclusion such as an agreement between actors and challengers. A last phase can also be signaled by the introduction of a different issue that is intended to draw media and public attention a way from the enduring issue. The phases in these three case studies, although arbitrarily decided, also reflect Fishman's (1980) phase structures and common logical understandings of how a story is constructed. The usually large disparities in numbers and percentages of media coverage from one phase to the next in these case studies (see Tables 5, 15 and 25) confirm these decisions as logical choices.

Each of the three case studies shows a different phase pattern. If the OPSEU phase pattern of media coalescence around the opposition in the first phase as a reaction to a government action and the Megacity phase pattern of coalescence around the government actors in the final phase can be used as the standard, then deviation from the pattern, as takes place here, may be important. The Megacity phase pattern started with the same reaction/opposition pattern, but did not have coherence in the middle phases and showed a slight variation at the end. This is consistent with the complexity of the issue, the large number of actors and the government's internal incoherence. In Table 26, however, all three phases of the Bill 160 story as reported in the media show the dominance of provincial government actors with only a slight variation. Media reliance not only on authoritative actors but government actors shows the strength of primary definition and, by extension, institutional accommodation that is consistent throughout all three phases. Despite the entry of new public actors that challenge the dominant meaning system, the government was able to establish preferred 
Table 26

\begin{abstract}
Authoritative Actors and Challengers in Mainstream Print Media Coverage on Bill 160 (Education)

(September 22-December 2, 1997)
\end{abstract}

by percentage

\begin{tabular}{lccc}
\hline $\begin{array}{l}\text { Main Political Actors } \\
\text { (1t reference only) }\end{array}$ & $\begin{array}{l}\text { Phase 1: } \\
\text { Legislation }\end{array}$ & $\begin{array}{l}\text { Phase 2: } \\
\text { Consultation/ } \\
\text { Strike }\end{array}$ & $\begin{array}{l}\text { Phase 3: } \\
\text { Amendments }\end{array}$ \\
\hline Provincial Government & & & \\
Globe \& Mail & 48.4 & 34.3 & 31.9 \\
Toronto Star & 34.8 & 49.2 & 24.6 \\
Toronto Sun & 27.3 & 33.7 & 56.7 \\
Unions & & & \\
Globe \& Mail & 19.9 & 27.5 & 25.0 \\
Toronto Star & 34.2 & 36.4 & 18.0 \\
Toronto Sun & 29.1 & 27.7 & \\
& & & 18.5 \\
Challengers & 13.5 & 10.8 & 23.5 \\
Globe \& Mail & 21.2 & 34.3 & 29.2 \\
Toronto Star & 6.6 & 20.4 & \\
Toronto Sun & & & 9.2 \\
& 13.5 & 18.9 & 0.0 \\
General Public & 7.6 & 3.5 & 3.6 \\
Globe \& Mail & 6.7 & 8.4 & \\
Toronto Star & & & \\
Toronto Sun & & & \\
\hline
\end{tabular}

Figures refer to main categories of actors only.

Columns and rows do not add up to $100 \%$.

Challengers category refers to individual parents, students and pro-government and antigovernment citizens' groups.

reading on its education reforms at the beginning of the policy cycle that would inevitably lead to media dismissal of the issue after the bill passed into law.

Using these three case studies and their different phase patterns as examples, it seems that the critical phases in a complex issue are both the first and the final phases. If a political issue is to succeed for a government, it must establish the dominant frame in the first phase. If coherence cannot be maintained or re-established in the final phase, this represents an unresolved issue with political repercussions. In the poll tax 
case in Great Britain, a piece of legislation that the majority government withdrew, there was a continued high level of media coverage and public opposition in this last phase (Deacon \& Golding, 1994).

Importantly, whether their paths are messy or consistent throughout the phases of their stories, all three cases lose media salience in their final phases. The Megacity phase pattern, with its several inconsistencies, can be seen to demonstrate the potential for an issue to endure-yet, resistance tapers off, the bill passes and the media lose interest. Despite its event-studded storyline that provides entry points for challengers and despite the commonly-held belief of challenger groups that the public had turned against the government (Latter, 1998; Crump, 1998), the Bill 160 phase pattern never fragments and never deviates from the phase pattern that a less controversial issue might have. Similar to the megacity story, Bill 160 becomes a non-issue after it passes into law. Interestingly, Ontario Teachers' Federation President Eileen Lennon said in a post-Bill 160 speech that OTF polling showed that support for the teachers remained consistent throughout the walkout. Media reports, as has been mentioned, spoke about the "battle for public opinion". The phase pattern goes against the grain not only of public opinion, but of media opinion, yet the amount and type of media coverage in the last phase does not reflect this. As the next chapter will show, even the government saw the Bill 160 fight as part of a resistance effort that had blown it off-course.

As was shown in the Bill 160 phase structure, the government set the agenda for the media throughout the life of the issue, from the introduction of the bill to its passing three months later. The phases also show, however, that media coverage remained elevated in the last phases (compared, for instance, to the Megacity final phase), an 
indication that the issue retained a level of salience even after the strike was over. As John Kervin, professor of Industrial relations at University of Toronto's Centre for Industrial Relations, told the Globe at the time of the OPSEU strike, that in public sector strikes, "if the inconvenience is sufficient, there is a big initial outcry against the union. Then, as the strike continues, there comes a turning point in which the anger is directed against the employer". In strikes involving teachers, the "swing usually occurs about the two-week mark" (Mittelstaedt, 1996:A2). Given perceptions that the teachers "won the PR war" only to "fracture at the moment of their triumph" (Walkom, 1997:A6), would the outcome for the government have been different if the strike had continued, instead of coming to a "disastrous end to a series of stunning political victories"? (A6). In this case study, the government's perceptions correctly gauged the tenor of the fight. The consistency of the phase structures may be linked to the government's growing sophistication and control of its neo-liberal agenda and the communications strategies that supported it.

Compared to the previous tables from the other two case studies on the type of media coverage (Tables 7 and 17), the Toronto Star and Sun both increased the percentage of coverage devoted to editorials and commentary (see Table 27). Increased commentary is seen often as an issue moves from a hard news phase into an interpretive stage, so it would be reasonable for both the Sun and the Star to examine the continued opposition to the Harris government in a cumulative way; a scan of commentary, however, shows little sustained interpretation arising from a cumulative analysis of the government's agenda or contextualizing within the Days of Action. In fact, 
Table 27

Type of Media Coverage in Mainstream Media: Bill 160 (Education)

(Soptember 22-December 2, 1997)

by number of items and by percentage

\begin{tabular}{lcccc}
\hline Media Outlet & News Stories & $\begin{array}{l}\text { Editorials \& } \\
\text { Commentaries }\end{array}$ & $\begin{array}{l}\text { Total } \\
\text { Items }\end{array}$ & $\begin{array}{l}\text { Total } \\
\text { Items per day }\end{array}$ \\
\hline Globe \& Mail & $48(69.6 \%)$ & $21(30.4 \%)$ & 69 & 1.0 \\
Toronto Star & $76(46.1 \%)$ & $89(54.0 \%)$ & 165 & 2.4 \\
Toronto Sun & $48(46.2 \%)$ & $56(53.9 \%)$ & 104 & 3.4 \\
\hline
\end{tabular}

Table 28

Type of Media Coverage in Business Media: Bill 160 (Education)

(September 22-December 2, 1997)

by number of items and by percentage

\begin{tabular}{lllc}
\hline Media Outlet & News Stories & $\begin{array}{l}\text { Editorials \& } \\
\text { Commentaries }\end{array}$ & Total \\
\hline Report on Business & $0(0.0 \%)$ & $2(100.0 \%)$ & 2 \\
Financial Post & $1(16.7 \%)$ & $5(83.3 \%)$ & 6 \\
\hline
\end{tabular}

Table 29

Type of Media Coverage in National Broadcast Media: Bill 160 (Education) (September 22-December 2, 1997)

by number of items and by percentage

\begin{tabular}{lccc}
\hline Media Outlet & News Stories & Features & Total \\
\hline CBC News/Magazine & $11(73.3 \%)$ & $4(26.7 \%)$ & 15 \\
CTV News/Canada AM & $18(75.0 \%)$ & $6(25.0 \%)$ & 24 \\
\hline
\end{tabular}


the Globe \& Mail sharply decreased the percentage of coverage it gave to editorials and commentary, as compared to the Megacity. Instead, commentaries follow a pattern of referring briefly to the government's overall problems and then concentrate on the specific issue at hand. The Days of Action are not mentioned. An exception is a column by Carol Goar in the Star (1997:E2) that called for "fairness and decency" in federal and provincial government policy. The sole story that mentions the Days of Action is on the elections of the Ontario Federation of Labour. The story focuses on the "bitter" division between the pro and anti-Days of Action factions (Urquhart, 1997b:E5). In this story, however, there is little mention of Harris's agenda and none on the purpose of the actions. Labour is thus once again isolated and decontextualized. Although business media (see Table 28) did not deviate from the other case studies in terms of the small amount of coverage, the national broadcast media showed an elevated interest in the Bill 160 story, compared to the other two issues examined here (see Table 29). Both teachers and parents were mentioned prominently in the 39 stories that CBC and CTV broadcast between them. In comparison, the other case study involving a strike, the OPSEU strike, fostered only 13 stories and the other case study involving public opposition, the Megacity story, fostered only eight stories. Clearly, the news value of grass-roots struggle to defend public education was greater than the value of a strike on its own or strong public opposition on its own. The higher national coverage of the education bill over the OPSEU strike or the amalgamation issue shows a perception and image of struggle that was greater than the actual amount of media coverage reveals. 
Table 30 and Table 31 examine the intended and actual messages of the government and its challengers. The government's intended message-set is richer in scope and language than the messages used in the OPSEU strike, but still relies on traditional notions of labour. Here, the government has the added tool of the 'illegal' strike. In the intended Megacity messages, the government melds the fiscal responsibility message with the policy goal, but either did not express the message in the same way to the media or it was not reported. In the case of Bill 160 messages, the government's actual message strongly made use of a melded policy (quality education) and fiscal responsibility (we can do better with less) message. On different occasions, however, new messages were introduced into the debate by the Premier and the provincial treasurer, making for a confusion of spokespersons that may have diluted the message. Just as in the previous two cases, the Premier's media quotes were more aggressive and ideological, hitting the intended messages but with more force. Minister Johnson, once again, provided a gentler contrast, but he seldom expressed the intended messages. For instance, while Premier Harris said, "no union sets policy in this province. The government is elected to do so and we'll continue to do that"' (Rusk, 1997:A3) and "don't let your union leaders push you into an illegal situation" (Mackie, 1997:A1), Johnson said in the same article "there are prospects this could go on for some period of time". Although the government's communications strategy called for coordinated messaging, this was not evident in the execution (MEdT, 1997b).

Challenger messages were designed to hit the main points the teachers wanted to make of protecting public education against a government bent on cutting its funding and taking control away from communities (see Table 31). OTF spokesperson Eileen 
Table 30

Government Messages on Bill 160 (Education)

Intended

Fair and reasonable

- we are being fair and reasonable

- we have already responded to the key concerns

of classroom teachers

- we want to sit down with the teachers and have a meaningful discussion but instead we get an illegal strike

We will not compromise our goals

- we are flexible about meeting our goals, but will not compromise our goals

- we are committed to ensuring the continuity of learning to the fullest extent possible

Personal interests vs students' interests - we all have to put our personal interests aside for the sake of the students

- students should not be used as pawns in the unions' dispute with government

Quality of education

- the quality of education is far too important to be held hostage by the teachers' illegal action - Ontario pays more per student than other provinces and gets worse results

The strike is illegal and a threat to student safety - students' education is too important to be held hostage by the teachers' illegal strike

- we will take action to minimize the disruption to the lives of parents and students

- our goal is to ensure the safety and security of Ontario's students
Actual

Cutting education costs

- the direction of the government is to improve the quality of education and keep cutting taxes (Premier)

- we are not getting value for money/we can do better with less (Premier)

- the CSR said there's a lot of waste, a lot of duplication, too many trustees, too many bureaucrats, too much fat (Premier)

- we have not taken $\$ 1$ billion out of the education system (Min. of Finance)

Quality of education

- we made a promise to improve the education system (Premier)

- school boards and unions are not to be trusted to deliver public education/are to be blamed for the erosion in standards (Premier)

Investment and education

- Bill 160 is an essential part of the government's program to boost the province's economy (Premier)

- business is telling us that quality education is the No. 1 factor in investment decisions, in creating jobs, in creating growth (Premier) - Ontario's future lies in turning our education system into a competitive advantage for Ontario against the rest of the world (Premier)

Personal interests vs students' interests

- they (unions) are using pupils as pawns (Premier)/our young people are caught in the middle (Min. Johnson)

- this is the day we tell all the special interests who put their agendas ahead of our students that enough is enough (Premier)

- the teachers' strike could create lasting damage in the school system (Min. Johnson) - let's put our children first (Premier)

The strike is illegal and a threat to student safety - we live in a law-abiding society where breaking the law is not the right example (Premier)

- do not let you union leaders push you into an

illegal situation (Premier)

- it punishes only parents and their children (Premier)

- I'm calling on the teachers not to follow through with their illegal strike. I don't want to see any child hurt (Min. Johnson)

Unions vs govemment

- the government not the unions will run the education system (Premier)
Message categories are in descending onder of prominence.

Sources: News releases and communications plans, Ministry of Education and Training; Globe \& Mail, Toronto Star, Toronto Sun. 
Table 31

Challenger Messages on Bill 160 (Education)

Intended

Cuts to education

Bill 160 is a power and money grab

Centralizes control

The bill takes control of education away from local communities

It centralizes control of education at Queen's Park

Protecting public education

Teachers are fighting to protect publicly funded education for our students

Speed of change

The government is moving too fast
Actual

Quality of education

- Bill 160 has nothing to do with quality education; it provides the tools to take 10,000 teachers out of the system (Lennon, OTF)

- we forced the government to reveal its true intentions - to cut funding and lay off teachers (Chenier, AEEO)

- we are protecting the quality of education from government cuts (Lennon, OTF)

- what they want is central control, shut out local input and to take millions out of education

(Lennon, OTF)

- it's all about cost cutting (McLeod, Liberal MPP)

- Bill 160 will not improve education, it is a power grab by the government (Lennon, OTF)

- you can't make cuts in education and improve quality at the same time (Nyberg, School Board Chair)

Protecting public education

- the fight is not for salaries and prep time but for preserving the education system (Lennon, OTF)

- teachers are defending publicly funded education (Lennon, OTF)

- public education in this province is in danger. (Lennon, OTF)

[after walkout:]

- we are returning to work for the good of our students (FWTAO, OPSTF, AEEFO)

Kill the bill

- kill Bill 160 or get ready for a long strike

(Lennon, OTF)

- we are determined to continue to fight as long as it takes (Lennon, OTF)

- we're not giving up (Sadem-Thompson, FWTAO)

Unions vs govemment

- the government is bullying teachers by seeking an injunction (Sadem-Thompson, FWTAO)

- removing principals and vice-principals from the bargaining unit is another example of the punitive nature of the government (Manners, OSSTF)

Message categories are in descending order of - [removing the principals and vice-principals] is nothing short of union-busting (Lennon, OTF)

- we have undermined the credibility of the government (Manners, OSSTF)

- the government denied that Bill 160 was to take money out of education. We were right (OPSTF) 
Lennon tended to stick to the script, which was stark and repetitive, but increasingly believable as the government's intention to cut more education spending was revealed. The five teacher unions had their own spokespersons, who also used the messages, which gave their political campaign against Bill 160 a coordinated and united appearance. Unlike the Megacity debate, in which the multitude of actors and messages created confusion, it is clear from the public actors that Bill 160 was a battle for the future of public education. The messages only showed dissonance in how to achieve that goal.

\section{Public Opinion}

The union messaging in itself may have been resonant with the public, but another factor-credibility of spokespersons - may also have been at play here. It is clear that the government and media frame of self-interested unionists faltered in the Bill 160 debate and this has been attributed to the reputation of teachers. In surveys testing credibility, unionists and government generally rate low, while teachers are among the highest rated (Ipsos-Reid, 1996a; 2003). This is a significant advantage in conveying a message.

Like teacher credibility, the subject matter of the debate is also a factor in the ability of teacher and other challenger messages to gain access to the media. Health and education continue to be the top issues affecting Ontarians, according to public opinion research. ${ }^{42}$ The concern of the public for education is seen in tracking polls that see

\footnotetext{
42 Ipsos-Reid syndicated polling during the Bill 160 campaign shows that education (at 55 percent) displaced health (at 28 percent) as both the top concern and the top driver of Ontario voter disapproval. Ipsos-Reid, 23 February 1998.
} 
education overtake health as the top issue during the Bill 160 debate (Ipsos-Reid, 1998). An Environics poll conducted for the OTF during the walkout showed high levels of parent concern, as well as support for teacher positions (Mackie, Lewington \& Claridge, 1997:A1). A poll taken after the walkout and the leak said that $46 \%$ of Torontonians felt the teachers were fair and reasonable, compared to $31 \%$ who supported the government (Ipsos-Reid, 1997a). A CTV report on the fifth day of the walkout showed "public support quickly shifting from the province to the teachers" (CTV, 1997). As (1997e) polling showed, by the time Bill 160 was passed, public faith that the government was "on the right track" had dropped to the lowest point recorded.

The public opinion research findings and the content analysis together demonstrate that the three Toronto newspapers lagged behind public opinion. The media allowed the government to frame the Bill 160 debate and only deviated when the frame became visibly inaccurate as the government's true fiscal agenda was exposed through the leak and as the injunction ruling framed the teachers and their motives differently. A scan of Toronto Star editorials shows that the newspaper took a decided stance in support of the government's position and only declared after the leak that "Tory credibility on schools [was] shattered" (Toronto Star, 1997:E2). It is only later, however, that the Star's last editorial during the walkout makes reference to the teachers having won the "battle of public opinion" and that their "protest has galvanized public opinion" against the government (Star, 1997:A26). The newspaper's final editorial on Bill 160 refers to widespread opposition: "[W]e all owe a debt of gratitude to the hundreds of thousands of Ontarians who created a public debate through a grassroots 
movement unique in modern history, one that spanned political parties, geography and religion to oppose Bill 160" (Star, 1997:A18).

The original frame constructed by the government (as primary definer) and picked up by a media (as secondary definer) routinely used to characterizing labour action as self-interested faltered because it was not clear to the public that teachers, as white-collar workers, were self-interested unionists. The teachers weren't asking for anything that was recognizable as pertinent to an industrial conflict, but instead, were questioning government control over education and demanding democratic representation. As the OTF communications strategy points out, the government was surprised at the recognition factor and resonance of the teachers' messages (OTF, 1998).

In keeping with Deacon and Golding's (1994) findings of mutual reinforcement between public and media, the public discourse now reflected a different, contested dynamic. Although the self-interest frame was still in play (parents asked to hear from other parents, not from teachers), the change was that parents and media questioned their previous understandings of the issues at hand. For Annie Kidder of People for Education, the public began to pay attention only when the teachers walked out. When they paid attention, they realized that the bill's centralization powers and reduced education funding "threatened their communities and their way of life. Teachers and parents' groups handed out good information and the more [the public] read about it, the more they were on side. [The walkout] forced people to act who had never acted before" (Kidder, 2003). Despite this increased public interest, media coverage declined as the bill faced passage, although as late as November 21, front page coverage in the 
Star began "They're organizing petitions, holding meetings and writing to their MPPs. Momentum is building among parents" (Small, 1997b:A1).

\section{Conclusion}

At this mid-way point in the government's mandate, sectors of the public were still strongly resistant to neo-liberalism, as this case study shows. Although the activist campaign against the Harris government was showing signs of fatigue after two and a half years of Days of Action and trying to fight on the many fronts in the government's 'divide and conquer' strategy, the neo-liberal project had not sufficiently entered into public consciousness for the education bill to pass without contestation.

The government's educational restructuring initiative is situated within the context of its overall legislative and communications offensive to implement its neoliberal project. It relied on the pattern it had used previously and successfully based on similar neo-liberal campaigns in other jurisdictions. Its strategy, however, was hampered by its own errors and its lack of depth. In this case, it constructed a narrow frame that was reinforced by the media. Toronto Star columnist John Ibbitson (1998) suggested in a post-mortem column on Bill 160 that the government had a "thin strategy" that relied on the injunction. When that was denied, although it had communications plans, it had no backup plan or worst-case strategy at a critical point in the campaign. ${ }^{43}$ It further held the interest of the media by limiting public consultations

\footnotetext{
${ }^{43}$ Ministry communications plans obtained under Freedom of Information legislation show that the government had an issues management plan in case of a teacher walkout, but it related only to ensuring that ministry communications work continued in the event that teachers blocked access to government buildings. The document, "Contingency Plan: Communications Support Team", does not address changing the policy path (MEdT, 1997b). It should also be noted that even a good communications plan is only as good as its implementation. If it is not followed, it cannot be effective.
} 
that would have demonstrated opposition and by reiterating its message directly to the public through the Premier's television address. Although the passage of the bill was never in doubt because of the government's majority, the errors made by the government cost it the trust of the public and permitted resistance. Education stakeholders, both official sources (teachers unions) and unofficial sources (parents' groups), were able to interrupt the neo-liberal policy path and prevent the government from undemocratically excluding the public, although only temporarily.

Through its own destabilizing, the government created a crisis in the public education system which it then set out to fix. As we have seen in these case studies and in chapter 2's history of neo-liberal projects, this is a standard tactic of neo-liberal governments that seek to challenge the status quo (Williamson, 1994). In the previous case studies, however, the perceived crisis was defined, communicated and understood by the social actors broadly as the imperative to reduce the deficit and bring government under control; here, the solutions to the crisis constructed by the government were understood locally and specifically as affecting the future of every family in the province. In Ontario, the public's understandings about the quality of public education were strong and positive until the government began its restructuring.

The government was able to regain control of the agenda by the force of its majority mandate, and, as media content analysis shows (see Table 26), it authoritatively carried the issue in Toronto print media reports regardless of the resistance. Even with the resources that large organizations such as the OTF can bring to political protest, the blitzkrieg strategy, with all the legitimating resources of government behind it, can prevent or minimize opposition and the crisis construction 
carries with it the powerful discourse of authoritarian populism that is difficult to dislodge.

Despite this, the shift in public opinion during the Bill 160 debate was undeniable. The question for the government and for the voice of opposition was how sustainable or cumulative such contestation could become. Disappointingly for the opposition, public opinion research showed that although it managed to shake up the government temporarily, the government regained lost support (Ipsos-Reid, 1998). Although OTF vowed it would keep Bill 160 in the public eye, very little was heard from teachers or challengers publicly after the passage of the bill. If activity took place—and certainly some grassroots groups such as People for Education have developed institutionally over time-it was not reported in the media.

Similarly, the ongoing Days of Action continued to receive little media coverage, unless related to a specific action in a specific city on a specific day. Media reports on actions did not intersect with reports on resistance to Bill 160, although two such actions took place during the Bill 160 debate. The three cases themselves prompted media coverage that contextualized them within general resistance to the new government (usually in commentaries), but the resistance organized by the labour and social justice coalition had little profile in these reports. To the media, once the bill was passed, there was no new phase structure to keep the story going.

One aspect of the government's education restructuring plan received little notice or comment. Although these messages were not in its communications plans, the government clearly stated that it viewed education as an investment and had consulted with business on its needs from the Ontario education system (see Table 30). Even the 
name given the education ministry by the new government reflected its neo-liberal orientation: The Ministry of Education and Training. The government also connected education more closely with business by underfunding it, which would lead to more private sector partnering, and by contracting out portions of the new curriculum, traditionally developed within the ministry, to the private sector for the first time (Paquette, 1998:16). The government's orientation to education, give[s] priority to the economic role of individual learners as future producers rather than their political role as future citizens. In current policy analysis and political rhetoric, the traditional goal of public education for democratic citizenship is given formal consideration; in practice the education of democratic citizens has been subordinated to the demand for competitive workers" (Manzer, 1999:162).

Once again, the government erred in underestimating the possible resistance that existed or would emerge to counter its neo-liberal agenda. As in the other cases, it relied on and did not move beyond ideological messages that suggested that it believed the Common Sense Revolution and a legislative majority gave it the mandate to implement its platform policies: "We made a promise" and "the CSR said there's too much waste", in the words of Premier Harris. Instead, it may have been dealing with the effect of a new and unfamiliar discourse on a public which was instead highly receptive to the teachers' messages of a government not listening to the people and moving too quickly. One sign that this may be so lies in the messaging espoused independently by parents' groups. While some groups such as the oppositional Ontario Education Alliance were telling the government to withdraw Bill 160, what resonated the most with parent audiences was the alternative message that the government was going too far, too fast (Crump, 1998). This is confirmed by Ipsos-Reid polling (1997e), 
which found in the days following passage of Bill 160 that $68 \%$ of Ontarians believed that "in the past few years, the provincial government has acted too quickly in making its changes... more than half of this group ( $37 \%$ overall) says the government is moving 'much too quickly"'.

Despite the many challengers, the Bill 160 debate took place within the dominant discourse. Similar to Deacon and Golding's findings on the poll tax debate, the contestation showed that neo-liberal ideology had not spread sufficiently or widely to contain any challenge posed within it (Phillips, 1996). As with the Megacity debate, however, the main opposition to the bill was not ideological, monolithic or cohesive. Oppositional voices that called for the repeal of the proposed legislation, such as the OEA, were marginal. Alternative voices, which comprised the teachers' federations, People for Education and most grass-roots parents' groups, espoused a message ("too far, too fast") that did not challenge the central force behind the restructuring.

The government's strategy of not backing down neglected a political interest that was stronger than its ideological interest: "Even if the government is convinced of its own rightness, there may be a stronger political interest in conciliation, to avoid a continuing parade of allegations, the creation of confusion on complex issues and the accumulation of determined enemies" (Tiffen, 1989:190). The message from the opposition that the government was moving too fast seemed clear enough, but it was ignored as the government moved forward to fulfill its agenda. In all three cases, the government had tight time lines to meet: in the OPSEU strike, it had to have a negotiated agreement before the end of the 1995-96 fiscal year in order to meet its reduced expenditure targets (Ibbitson, 1997:159); in the Megacity case, it had to pass 
the legislation quickly in order to allow sufficient time for the fall municipal elections to be organized under the new regime (253); here, it had to ensure its own expenditure restraints were in effect before the previous government's 'social contract' expired and contracts and collective bargaining arrangements returned to their previous levels (Paquette, 1998:3).

The blitzkrieg communication strategy was thus critical to the government's ability to deliver on its promises, especially after it had alerted the public earlier in the year through Bill 104 that there was more restructuring to come. This advance notice ignored the lessons of neo-liberal policy implementation from New Zealand, in which the neo-liberal government's communications strategy on the Employment Contracts Act was to minimize the policy and not release the details of the legislation until it was introduced into parliament (Scott, 1997:188-9). The blitzkrieg allowed the government to push forward and avoid the prolonged and unsuccessful legislative process that had defeated Great Britain's poll tax initiative. Learning from the lessons of both jurisdictions, Bill 160 took only 10 weeks from announcement to third reading.

Despite the power of the blitzkrieg, the government's march forward was detoured by strategic errors that cost it public trust. The teachers gained the visible confidence of the public when the Ontario Court rejected the government's attempt to get an injunction against the teachers. Parents' groups, by virtue of their geographical dispersion, voluntary status, limited resources and varying degrees of media savvy (Deacon, 1996), were organized and worked against Bill 160 mostly at the grass-roots level. Their credibility was enhanced by the reaction of the general public to the court injunction. When the government's request for an injunction was denied, this gave the 
public a reason to reject the government and media's frame of teachers as self-interested strikers and for public opinion to coalesce around a mutual concern for democratic process.

The condition of the discursive terrain in Ontario at the time also may have been a factor specific to this campaign. The Bill 160 story occurred when the discursive field of neo-liberalism in Ontario was early in its development and the government had yet to achieve discursive authority. Bill 160 ended a year of upheaval that began with Megaweek, repositioned Ontario state-citizen relations and arguably was the initiative that forced individual people across the province to come face to face with the everyday meaning of neo-liberalism through their proximity to the educational system. Neoliberalism challenged their direct and long-held understandings of how the system worked and was thus confusing to the public.

This and errors it made in managing the communications campaign to sell its educational restructuring initiative created conditions that allowed parents and the public to interrupt and resist the government discourse at an emergent moment in its reproduction.

The next chapter will continue to focus on the case studies. It will compare and contrast them, and will contextualize them within the ongoing organized resistance to the government as exemplified in the Days of Action. An instance in which the government did not pursue a central plank of its election platform that is integral to neoliberalism-privatization-will also be examined. Based on the three studies, it will also attempt to make conclusions about ideological reproduction under conditions of the emergent hegemony in Ontario. 


\section{CHAPTER 5: CONSTRUCTING AND COMMUNICATING NEO-LIBERALISM IN ONTARIO: THE CASE STUDIES II}

\section{Introduction}

Deacon and Golding (1994:195) write of a dynamic interaction that can take place in government policy debates, public perceptions and media representations of issues. The three case studies in this thesis demonstrate how space for opposition and resistance can develop under the right conditions to foster this interaction: a government pressing forward with its massive and controversial restructuring agenda; issues that mobilize resourced and educated citizens to act; authoritative actors in conflict with each other; resource-poor media covering fast-paced, complicated and newsworthy stories—all within an emergent hegemony that strikes at traditional notions of what government does for citizens and what citizens need from government. Under these limitations and contested conditions, the Ontario government also faced decisions whether to proceed with an important aspect of its neo-liberal restructuring agenda--privatization. This chapter continues with the analysis of the case studies, but also examines the government's privatization agenda as an unfulfilled promise in the Common Sense Revolution and a rare pragmatic response by the Ontario government to resistance.

In addition, these case studies deliberately go beyond the dominant meaning system to examine the hegemonic struggle in the first two years of the mandate of the new Ontario government in attempting to implement its neo-liberal policy agenda. They provide details of the contested and competing communications 
strategies of alternative and oppositional actors—Larner's (2000:14) "messy actualities"- to demonstrate more completely the social, political and economic complexity of this neo-liberal government's communications campaigns to gain consent and legitimate its policies. Unlike other analysis, this approach interrogates the idea of ideological coherence as determined in a linear and reciprocated manner (Deacon \& Golding, 1994:195). As these case studies show, these communications campaigns, in fact, are rife with "contradictions, complexities and inconsistencies" (16) and their outcomes are not always predictable. Interruptions do occur in the process of transition from one paradigm to another and can reveal more clearly than a narrower examination of the dominant meaning system how ideological reproduction can take place. In addition, the tables relating to the three case studies show communication's key role in structuring understanding and winning popular consent for the emergent hegemony.

\section{Hegemonic 'Failure'}

The three case studies in this and the previous chapter have emphasized both the resistance to the Harris government at the beginning of its mandate and its successes in realizing its restructuring agenda. There were, however, areas of its agenda that did not live up to its promise in the Common Sense Revolution election platform of the Conservatives. In it, the Conservatives promised to "actively explore the sale of assets, including TVOntario" (CSR, 1994:17). Ontario Hydro and the Liquor Control Board of Ontario (LCBO) were also targeted. Although privatization was and is a major aspect of neo-liberal projects, each of these institutions provides a 
story of attempted privatization by the government that failed and can help "construct the conditions under which a major ideological initiative comes to grief or is significantly deflected"' (Golding, 1992:514). This possibility of failure is significant, given the widespread perception that the persuasive efforts of neoliberal governments, embodied in "communication offensives", are "unprecedentedly successful in the business of winning hearts and minds, this being both the source of their rise to power and a major feature of their political strategy" (507). The case of the provincially funded educational broadcaster, TVOntario (known as TVO), is a good example of the early failure of such offensives as it falls almost completely within the transitional time-frame covered by this thesis. Not only is it cited specifically in the CSR, but Premier Harris made reference to it in the weeks following his election: "How can we get the best quality service at the best price, that's the objective of the government. If privatizing TVO can accomplish that, then we're prepared to privatize TVO" (McCann, 1995:C9). Harris followed up on this by mentioning TVO in his government's first Speech from the Throne in September 1995. It was made even clearer that the new government intended for privatization to form a central part of the agenda for its first mandate when it created the province's first Office of Privatization with a Minister without Portfolio with Responsibility for Privatization (Rob Sampson).

TVO was a good candidate for privatization, as there was a widely-held belief that the network was bloated and needed an overhaul (Toronto Life, July 1996). What was misunderstood politically or ignored ideologically, or both, by the new government was the potential for public support of TVO, as well as the impact 
of TVO's internal efforts to survive without being privatized. TVO had anticipated the need to reinvent itself and had already adopted a comprehensive, internal strategic plan early in the 1990s (Kozolanka, 2001:59). In effect, the plan was a pre-emptive, public relations 'campaign' to save the network, based on the "quality of content and efficiency of delivery" (Raboy, 1996:179) that were seen as the keys to success in broadcasting.

Although the expectation was that the privatization battle over TVO would be fought early in the government's mandate, the review was delayed and a media report suggested there was internal conflict in the cabinet as to how to handle TVO. The review was finally announced in June 1997 (Mackie \& Harris, 1997:A1). At this point, a second campaign joined the efforts of TVO management, a more overt one that was managed by a collective of actors from the union local at TVO, CEPNABET Local 72M. The campaign's province-wide activities consisted of news releases, pamphlets, speaking engagements, fundraising, a video, buttons and advertisements (Kozolanka, 2001:57).

TVO's not-so-secret weapon in the campaign was the people of Ontario, a huge collective set of actors. There were three overlapping sets of Ontarians. The largest group was the 11 million citizens of Ontario, followed by a smaller group of 2.4 million TVO viewers, followed by a still smaller group of about 85,000 members, through whom TVO had an initial supportive and identifiable stakeholder group. On-air membership drives that appeared regularly throughout this time included messages that TVO was under threat. 
Partisan political opposition at Queen's Park also actively opposed privatization of TVO in the legislature. This is an important feature of policy campaigns in terms of receiving media coverage and public exposure: "If an issue is marginalized by the main political parties, it is highly unlikely to attract consistent attention in the media" (Deacon \& Golding, 1994:182).

The media were also important actors in the framing of the TVO issue. Most cultural analysis in Ontario is carried out by cultural columnists of major Toronto newspapers, supplemented by trade magazines and the occasional mainstream magazine article, all of which provides a consistent history of support for the big cultural institutions, including TVO, that are housed in Toronto (Kozolanka, 2001:58-59). A scan of the three Toronto newspapers, business and trade magazines from 1993 to 2001 revealed consistently positive and supportive coverage of TVO, despite concerns that it needed to be overhauled (59). As an example of TVO's significance as a cultural institution, four major Ontario newspapers (two of them in Toronto) endorsed TVO's alternative plan within four days of its release.

There were two important moments in the campaign. First, TVO announced in June 1997 that it had developed and delivered to the government its own plan for survival. Under the plan, TVO would become a not-for-profit agency and would receive government funds on a fee-for-service basis. The strategic value of the proposal was its rejection of the status quo and a symbolic openness to striking out in a new direction while retaining its core mandate (59). 
Second, as part of its privatization review, the government struck a threemember panel to lead a community forum in each of five cities, where participants could respond to six pre-determined questions. The panel reported back in February 1998 that there was "clear public opposition to selling TVO to private interests. [P]articipants told us they would urge the government to consider TVOntario both a public service and a good investment" (Levy, Adam \& Smith, 1998:26).

Public opinion research consistently showed that Ontarians supported TVO against the government. In December 1997, Environics found that $60 \%$ of Ontarians polled opposed a sell-off of TVO, a notable increase of $12 \%$ from just three months earlier. The polling company suggested that opposition to selling off TVO "intensified... perhaps as a result of the province-wide public hearings" (Environics, 1997:1).

In June 1998, the government announced that TVO was to remain a provincial agency and become "the vehicle which launches the province's lifelong learning vision" (OP, 1998:1). Although not privatized, the government had rejected TVO's plan in favour of refocusing its mandate and encouraging private sector partnerships.

The TVO campaign, in the context of this thesis, is a reminder that the three case studies that show successful legitimation efforts by the government do not represent the entirety of the ongoing public debates during the period examined (1995-1997). The TVO campaign, for instance, took place during the Bill 160 teachers' walkout and TVO may have gained support from the public resistance to the government's vision. 
The TVO story illustrates the limits of state ideological domination and reproduction. Given that the TVO campaign occurred within the time-frame of this thesis (1995-1997), where the three case studies here show how the state can, despite resistance and contestation, win, it also presents questions on why some initiatives can invoke "media or public outrage" and not others (Deacon \& Golding, 1994:200). The retreat by the government also demonstrated a rare pragmatic response to resistance that was echoed in its other privatization efforts during its first mandate.

The retreat from privatization did not go unnoticed. An article appearing in Report on Business in June 1999-the month of the Harris government's second election win—charged that " $\mathrm{f}] \mathrm{ar}$ from opening up Ontario for business, the Tories squelched competition in areas as diverse as intercity busing, alcohol sales, municipal waterworks, laboratories and casino gambling, bestowing favour instead on dominant players that were either of the state or nurtured by it" (Crittendon, 1999:51). Business criticism about the entire privatization agenda suggests that there were reasons other than lack of commitment to privatization why the government did not move it forward. Later in this chapter, it will be suggested that public resistance to the government was having an impact, leading the government to begin to pull back on its commitment in preparation for the next election.

Deacon and Golding (1991) suggest two conditions under which state agenda-building can fail. First, the lack of internal political cohesion in the governing party "can fundamentally undermine the government's initiative" (311). Such dissension was evident in this case (Mackie \& Harris, 1997:A1; Kaihla, 
1998:22) and decisions not to sell off TVO "represented a victory by pragmatists" in Harris's cabinet (Kaihla, 1998:22). Second, an organized and resourced opposition can create "considerable political and public relations counter-response" (Deacon \& Golding, 1991:311). This was also a factor with TVO, ${ }^{1}$ which "won the public opinion battle" in its fight against privatization (Kaihla, 1998:24). Although the government only retreated so far, it was a clear loss, especially when other privatization efforts were also unsuccessful. Deacon and Golding also point to the increasing power of the media by media concentration and the increasing power of government communications as it shifts to a public relations orientation as additional factors in the success or failure of state policy offensives. Chapter 3 has also discussed the systemic changes, such as changes to legislative and parliamentary practice, that the government began to use to control partisan political and public opposition that, by this time (1997) were already having an impact on how the government was conducting its 'business'.

\section{Legitimation and Consent}

The Harris government, on its part, tried to reduce the opportunities for entry points to break into the debate by making use of the power of the state legitimating apparatus and resources. The legitimation strategies the Ontario government used in the first months of its mandate rested on two divisive tactics that first emerged in the Common Sense Revolution prior to coming to power. The first was a 'divide and

1 A similar situation existed with LCBO: "Under the threat of privatization, the LCBO has expanded its outlets, takes credit cards and is open on Sundays. Its employees' union also launched a \$3-million anti-privatization campaign in 1996 with ads featuring a key theme not lost on Harris and Eves: this state enterprise actually turns a profit, pouring about $\$ 750$ million a year into provincial coffers" (Kaihla, 1998:24). 
conquer' strategy (Woolstencroft, 1997:38) of polarizing the citizenry, or, more accurately, the narrower group of citizens that formed the electorate, by dividing groups into the 'worthy' and 'unworthy' (Herman \& Chomsky, 1988:345). This tactic pits groups against each other by "stereotyping and isolating" (Laxer, 1996:F3) the unworthy and privileging the worthy. Not only did this divide welfare mothers from executives, but it divided worker from worker, as in the collective agreement the government reached with one of its smaller public sector unions while the OPSEU strike was going on (Ibbitson, 1997:175; Rapaport, 1999:195). The second tactic important to legitimation was the equating of opposition to special interests, while the emerging dominant interests such as business becomes the voice of society by virtue of what Knight (1998:116) calls "identity displacement" and Thompson (1990:61) calls "universalization". These strategies signalled a change in traditional Ontario political culture to a less balanced and more competitive culture. A Star editorial (1996:A22) after the violence at Queen's Park during the OPSEU strike said that Premier Harris "prefers to exacerbate divisions, rather than forge a consensus". His government "marked by... upheaval", he "will not be seen to be giving in". The Star urges the Premier to "govern in the interest of all Ontarians" (A22).

Communications strategies undertaken by the government for the pursuit of consent included public opinion research and advertising, but establishing the cost and range of this communications support is hampered by the government's 1995 changes to Freedom of Information and Privacy legislation. OPSEU was able to obtain information on such expenses related to its second strike in 2002 that showed 
the government spent more than $\$ 3.1$ million on newspaper and radio ads (OPSEU, 2002). OPSEU spent $\$ 930,000$ on advertising related to the same strike. ${ }^{2}$ Both the government and the union used radio and television advertising in 1996, although approval to air some union television ads were refused by the approving body on a technicality. ${ }^{3}$

The main actors in the Megacity debate all relied on modern publicity processes to help legitimate their positions. The government spent $\$ 3.3$ million on advertisements, $\$ 2.5$ million of which came from ministry advertising budgets to explain new initiatives, preferring advertising - directly speaking to citizens-to relying on journalists to get their message out (Ibbitson, 1997:258). In addition, the government spent $\$ 300,000$ on a householder pamphlet to all homes in Toronto. It also conducted substantial public opinion research, for which no cost is available. ${ }^{4}$ The government's campaign to build support for amalgamation had a setback when the Speaker of the legislature ruled them and Minister Leach in contempt because they didn't specify that the initiative being promoted would only come into effect when passed into law (Ibbitson, 1997:259). ${ }^{5}$

The City of Toronto spent $\$ 1.6$ million on its share of the referendum costs, a public information campaign, campaigns in individual city wards and funding for

2 The union claims that the government spent $\$ 250$ million on advertising between 1995 and 2002 (OPSEU, 2002).

3 The Telecaster Committee of Canada "denied OPSEU permission to run the advertisements because the commercials didn't contain an announcer voice-over advising viewers the commercials were 'paid for by the Ontario Public Service Employees Union'. OPSEU did take ownership of the commercials with a printed version of the message at the end of each commercial" (OPSEU, 1996a:1).

4 Ipsos-Reid conducted the research on behalf of the government (Bricker, 11 November 2002). Although a Freedom of Information and Privacy Act request was submitted concerning polling related to Bill 103 , only one pre-amalgamation poll was identified.

$s$ This marked the first time in the history of the Ontario legislature that a Minister had been so censured (258). 
an anti-amalgamation citizens' group (DeMara \& Moloney, 1997:A4). The City of Etobicoke spent $\$ 250,000$ on its own poll and the City of Scarborough spent $\$ 100,000$ on its own referendum (A4). The City of North York spent $\$ 450,000$ on its share and an undisclosed amount on advertising (Goldstein, 1997:C3). The Canadian Union of Public Employees spent between $\$ 100,000$ and $\$ 150,000$ on radio ads and billboards (Donovan, 1996:A6). ${ }^{6}$ In contrast, the $\$ 2,500$ to $\$ 3,000$ that C4LD raised weekly at the height of the debate by passing the hat at meetings did not allow for polling and advertising, but was allocated to hall rentals and printing (Rykert, 2003).

The government's campaign to construct consent and legitimate its educational restructuring initiative cost $\$ 3.5$ million in advertising, not including the $\$ 800,000$ the Conservative Party paid for the Premier's television address (Ruimy, 1997:25). ${ }^{7}$ Documents obtained under Freedom of Information legislation show that the government's tracking polling for the Bill 160 period cost $\$ 195,000$. The teachers' federation paid $\$ 1$ million for its radio, television and newspaper advertisements (Ruimy, 1997:A24). Legitimation efforts are not confined to the direct costs of communications tools. As Paquette (1978:25) points out, the Ontario Teachers' Federation "vowed to keep Bill 160 before the public and promised, in that context, a series of constitutional challenges to the validity of various aspects of that legislation". The first of these cases to be heard was regarded by the court as

- CUPE's interest was the potential loss from amalgamation of the jobs of its members who were city employees, where much of the savings in the government-commissioned KPMG report were concentrated. CUPE's campaign was rarely referred to in the Toronto newspapers, except briefly when CUPE national president Judy Darcy made a presentation at the hearings on amalgamation.

7 If the government rather than the Conservative party had paid for the address, the two political opposition parties would have been given the right of reply (Financial Post, 27 October 1997). 
legally questionable and led the court to "question... the degree to which the courts may, in this situation, be part of what would best be described as a publicity campaign" (30). Given this judgement and the government's demonstrated preference for injunction strategies in its communications efforts (as shown in the OPSEU strike), the cost of the pursuit of legitimation of policies through the courts may be considerable.

In addition to the power of state legitimating apparatus, which clearly surpassed that of its challengers in publicity costs alone, the government also restructured the physical and symbolic polity in order to maintain control of its agenda by ensuring that such interruptions were minimized or negated. Through its privatizing strategies, for instance, the government has shifted power formerly held in the public sector to private sector or quasi private sector sites such as quangos (see chapter 4 , fn 37 ) with less accountability to the public. Where the government itself has control of the process, as it does legislatively, it uses effectively the "policy windows [that] may open and close in accordance with institutionalized electoral and political cycles" (Howlett, 1997:28). Government restructuring stimulates the growth of "a different kind of state and new ways of governing and regulating... development that fall outside the ambit of democratic public government" (Todd, 1998:199). The OPSEU strike was a struggle between the government and the union that eventually saw more than 11,000 provincial public employees lose their jobs, allowing public work to be absorbed by private, for-profit interests. In the same way, the Megacity story should be seen as a deregulating venture aimed at privileging business interests in their quest to develop and brand 
the Toronto as a global supercity (198). Bill 160 opened the doors to the private sector to create curriculum. It also allowed community business interests to play a role in local education by guaranteeing a seat for local business on mandatory school councils (MEdT, 1997g). Deacon and Golding's (1994) dynamic interaction, as they themselves point out, must therefore be seen as "structurally imbalanced, with certain arenas 'over-accessing' others"' (195). The over-accessing reflects the institutional and structural power of the government, which it has strengthened through its policy initiatives throughout its mandate.

As the government moved ahead with its restructuring agenda, centralizing power and limiting the power sites of its opposition, the long-held balance between state and public under corporatism became destabilized. As in the development of Thatcherist discourse in 1980s Britain, the Ontario government by 1996 and 1997 had "secured a degree of sociopolitical and cultural change", but had not yet "gained total hegemony" (Phillips, 1996:218). Despite this, and by virtue of a solid electoral majority, the government was able to act and did act decisively throughout this time. Drawing on the experience of New Zealand with neo-liberalism, Kelsey (1994) writes that a government can act coercively (in the Gramscian sense as without consent) without fomenting popular dissent or crisis

if the mass of people remain indifferent to, cynical about, or tolerant towards the government's actions, and if the economic and social costs are spread amongst a number of poorly organized, non-cohesive, and politically unaware social groups. The secret lies in keeping people isolated, individualized, non-unionized, and disunited (183).

This speaks directly to Deacon and Golding's (1994) question of why some restructuring initiatives, which clearly will have adverse impacts on sectors of the 
public, go relatively unchallenged. They conclude that "[t]he truth is you can fool quite a lot of the people for much of the time", but there are indeed "limits to the power of state delusion" (200).

In order to minimize hegemonic failures, the Ontario government relied on a public environment conditioned by the federal government's discourse of debt reduction, which it then magnified with its own rhetoric of crisis, and, when added to its structural and policy changes, created sufficient disunity to allow it to act decisively. Thus its 'attack' on multiple, strategically chosen policy fronts in its first months of office mutually reinforced its discourse of special interest groups pushing government beyond its limits, and served to marginalize and discipline those offending groups of citizens (such as young offenders and social assistance recipients) that constituted the problem. The public employees represented by OPSEU were another special interest with too much power. As the case study shows, they were also an easy target, already stereotyped by notions of both militant unionism and lazy bureaucrats and now further stigmatized as self-interested special interests. Opponents of amalgamation were similarly seen as carriers of privilege, fighting on the esoteric ground of democracy while the economy burned. During the Bill 160 debate, the government sought to construct the same self-interested image with the teachers as more concerned with their perceived perquisites than their students. 


\section{Comparing Media Coverage}

This government both makes use of and bypasses the media as a necessary adjunct to its goals, whichever is strategically useful at the time. It has a general presumption of the importance of media in promulgating information or promoting a position, but this does preclude directly addressing the public to promote a policy. In each of the three case studies, the government spent more than \$3 million on advertising. In the Bill 160 campaign, Premier Harris addressed Ontarians directly on television. During these same periods, however, the government was eschewing consultations with the public, unless forced due to public disapproval. Paid public relations more reliably conveys a message, but it also replaces public dialogue. As Premier Harris made clear during the lead-up to the referenda on amalgamation, the results didn't matter anyway because the government already knew what it was going to do. Neo-liberal governments are intent on reaching their established goals, says Atkinson (1994a), not corporatist compromise (Ibbitson, 1997:246): "They seek customer views in less than genuinely democratic ways both because it is quicker to do so and because they share their client's interest in outcomes. They can only become fully consultative, down as well as up, if they lose this preoccupation with outcomes" (Atkinson, 1994a:210). Thus citizens are subject to persuasion from advertised government messages, treated like consumers, rather than engaging in two-way dialogue with their government.

In its use of the media, the government initiatives provided access to lead ministers and the Premier through media scrums and interviews. This was made easier for the media through the institutional accommodation that provided 
regularized, routinized opportunities to the Queen's Park press gallery. Although the government's operational communications plans were not sophisticated and detailed at the beginning of its mandate, the intense opposition to some of its plans pushed the government into more structured communications planning and strategies in order to win consent. It became clear, as OPSEU Director of Communications Frank Rooney pointed out, that "the government had a political direction, it didn't have a strategic direction" (2002), that is, the government knew where it wanted to go, but didn't have a strategy on how to get there. As the message mapping of the three case studies show, the government, although still fully committed to its goals, permitted some flexibility on how to reach them, a pragmatic and strategic response. As the tables have shown, Hall's (1978) primary definition thesis held substantial sway in the three case studies. More so than in the studies from which the tables on political actors have been adapted, authoritative sources are prominent in the media coverage. ${ }^{8}$ Government sources in particular have a strong presence and should be considered to have overaccess to the media. Whether this emanates from overuse of institutional access or is a common feature of provincial political news coverage is a subject for another research project. What can be said, however, is that the media gave government actors more than sufficient space to argue their position. In addition, as the tables (Tables 5, 15 and 25) of phases of the case studies clearly show, the media were uncertain about how to cover the unfamiliar terrain laid out by the government in its restructuring initiatives and perhaps opted for the institutional accommodation as a default position. The

8 See Tables 4.2, 4.12 and 4.22. The studies are Hansen and Murdock (1985), Golding (1990, 1991), Deacon and Golding $(1991,1994)$ and Knight (1998). 
impact of these routine news decisions on the policy outcomes is difficult to isolate and measure, but can be understood in the context of how and when they deviate from primary definition. Thus, the amalgamation story as told by the media shows a more pronounced deviation than the coverage of the OPSEU strike. In the Bill 160 issue, on the other hand, the media accord the government primary definition throughout, despite the testimony of grass-roots challengers that substantial and vocal opposition to the government's education agenda existed (Crump, 1998; Kidder, 2003; Latter, 1998). Even the Toronto Star's (1997:A18) editorial perception was that Bill 160 inspired widespread opposition: "[W]e all owe a debt of gratitude to the hundreds of thousands of Ontarians who created a public debate through a grassroots movement unique in modern history, one that spanned political parties, geography and religion to oppose Bill 160". The Star made no such assessment of the opposition to amalgamation. Without a full-province media mapping, the reach of the Bill 160 issue across the province, especially when compared to province-wide amalgamation coverage, is difficult to assess. Clearly, the amalgamation issue was a Toronto-based story and it is highly likely that overall local coverage would be high-as it was--let alone that it would cover alternative positions as newsworthy-which it did. But the insignificant presence of alternative accounts on Bill 160 in the media shows that this aspect of the story may not have been given due coverage and the perception was left that there was no fundamental challenge by the media to the ideological parameters set by the government. As a

9 The editorial cartoon on the same page is described in archived coverage as follows: "Mike Harris pushing a school bus down a slope and into the abyss. A sign reading 'Bill 160 ' is pointing in the direction of the abyss". 
comparison, public actors/groups and members of the public together in the megacity case (Table 14) had a proportional presence in the three Toronto newspapers of 21.2\%, while their presence in the Bill 160 case was $15.3 \%$ (Table 24). Of course, this should also be judged in comparison to the $2.2 \%$ of challenger and public coverage in the OPSEU case (Table 4).

What is interesting about the extent of the government-led primary definition in all three case studies is how the government seemed to squander the advantage inherent in its capacity to construct a preferred reading of an issue. In privileging the ideological outcomes of its policies, it did not attend to their political ramifications. Only when resistance shifts from the outcasts of society, such as the unionists in the first case study, to the mainstream, as seen in both the second and third cases, did the government seem to realize that a strategic and political approach may be required. The strength of primary definition in these case studies suggested that even the backbench dissent evident in the amalgamation and Bill 160 case studies, although accorded media coverage, ultimately did not detract from the overall dominance by government of the coverage. In particular, Premier Harris, through his stature as Premier and his more aggressive (and thus more newsworthy) media messages, had a strong presence in these case studies.

The phase approach to mapping the media coverage not only makes visible the variations in media coverage, but demonstrates how coverage is linked to the policy and legislative cycle. As Fishman (1980) has shown, and Tables 15 and 25 confirm, media phase structures can reflect the bureaucratic life cycle of a policy that is attached to legislation. Depending on the substance of the legislation, high 
points in media coverage relate to the introduction of the legislation, consultations, amendments and ultimate passage. This cycle when coupled with primary definition and institutional accommodation provides expanded opportunities for government to establish preferred readings of bills. In their study of Great Britain's poll tax initiative, however, Deacon and Golding (1994) found that the controversial bill did not mimic the cycle of media coverage as expected; instead, strong opposition to the bill was sustained and media coverage, although varied in amount, was maintained. Although the peak of coverage occurred when the bill was introduced into the legislature, this occurred after resistance had grown over many months. One of the lessons that New Zealand took from Great Britain's experience with neo-liberalism is a more streamlined approach to legislation that gives little or no advance notice, no promotion of the policy, little consultation and truncated timelines aimed at reducing opposition (Scott, 1996). When the Ontario government deviates from the New Zealand approach, as we can see from the Megacity and education case studies, it allows opposition to grow. The implication for policy development in Ontario, which already garners strong benefits from primary definition, is that the legislative cycle can, along with the New Zealand blueprint, provide a set structure for briskly moving to bill passage and avoiding public and media scrutiny. ${ }^{10}$ In effect, this allows the dominant hegemony to set the limits of debate and more effectively drive issues through the media. As Blumler (1990:103) has said, "[t]he modern publicity process involves a competitive struggle

${ }^{10}$ Or not achieving policy goals through legislation, if at all possible. Brearton (2003:6) shows that after its first mandate, which included massive legislation, the Ontario government substantially reduced its legislative agenda -as well as, it would seem, opportunities for the partisan opposition and other challengers to use the legislative-policy cycle to interrupt the government agenda. 
to influence and control popular perceptions of key political events and issues through the major mass media". When the outcome of the struggle with the media is in doubt, the government's other option of directly speaking to the public has proved fruitful.

Although media coverage of the Megacity and Bill 160 showed that the government was at times not in control of its agenda, the tables showing the phases of coverage also demonstrated that it regained ground under the influence of the legislative cycle, which logically focuses media attention back on the legislature and the government. Bill passage thus acts as the beginning of the dénouement even of controversial issues. For instance, the Toronto Star editorialized that Bill 160 should not be passed without "major surgery" (1997:C2), but two weeks later called for "[o]rder, please!" (1997:A36) ${ }^{11}$ from the public and political opposition after the bill's passage. The phase structures also demonstrate how the initial point of action both garners media coverage and gives opportunities to use intended messages, confirming the importance of "pseudo-events" (Boorstin, 1963) such as news conferences and other staged "informational subsidies" (Gandy, 1982:61) to stimulate interest and media coverage. Once the media canvasses the other actors for reaction, it is more difficult for the government to maintain message cohesion. A new phase in the policy cycle again provides a point of action and an opportunity to re-centre messaging and, if needed, regain control of the agenda.

\footnotetext{
"A Toronto Star editorial at the end of the amalgamation issue similarly called for a return to normalcy (1997:E2).
} 


\section{Government Communication Strategies}

The case studies illustrate other factors that contributed to constructing the conditions under which the Ontario government's initial communications efforts operated and were resisted. As has been noted, the new government's style in policy formation and implementation differed noticeably from previous Ontario governments, leaving behind the "generally moderate and measured character of its political life" (Woolstencroft, 1997b:385). The pre-construction and preconditioning of a rhetoric of crisis found play in simple, highly selective and repeated messages that brooked no diversion from its main goals (Atkinson, 1994a:201-2). The deficit/crisis rhetoric resonated so deeply that it was often unstated; in this way, themes in the media coverage precede events (Hansen \& Murdock, 1985:255), as in coverage of the OPSEU strike. Over time, the government came to understand as well the "central role of message coordination in modern political strategies" (Palmer, 2002:352). The government also became more adept and less blunt at framing and learned to adjust frames as events unfolded, while keeping to its main messages. The government already used "intermediaries to enhance credibility" (352). With its beginnings in public relations, this tactic of third-party testimony acted as a kind of product endorsement.

The government's rejection of consensual politics for confrontational politics found expression in its rhetorical tactic of referring to those who oppose it as special interests, be they union members or Toronto parents. In contrast, the government's supporters represent the 'dis-interested' who, through universalization or identity replacement get to speak on behalf of society (Thompson, 1990:61; 
Knight, 1995:162). This creates a more competitive public environment "where interests hurl themselves against each other until the most powerful prevails" (Ibbitson, 1997:285). This competition for access and the polarization that emanates from dividing citizens into the 'worthy' and 'unworthy' encourage the strategic alliances that allow the government to maintain its hegemony. Hugh Segal (1997), a pre-neo-liberal Progressive Conservative, writes that the neo-conservative philosophy "has trafficked in polarization - the creation of division for its own sake and in that process has diminished the balance and civility of our democratic systems, eroding public faith in government overall" (4). As seen in these case studies, consultations, usually the site of democratic dialogue between the public and its government, are avoided or minimized by the government. Without the more controlled environment of public consultations, citizens must compete with more powerful interests to have their voices heard by government.

The government's use of the blitzkrieg strategy, although flawed, was a recognition that real public persuasion takes time (Atkinson, 1994a:202); the government opted instead for "short-term manipulation" of the democratic process over "long-term implementation" (208). The blitzkrieg and other pre-emptive tactics, such as reduced public consultations, increased the government's chances of policy success. "Policy failures", as Deacon and Golding (1994:199) have said, "are communication failures". Bad policy alone will not sink an initiative, but bad policy in interaction with political failure can, and that political failure rests to a large degree on communication of the policy (Deacon \& Golding 1994:199-200). For a neo-liberal government with a dense policy and legislative agenda, the 
blitzkrieg limited the possibilities for 'blinking' in the 'hit hard, hit fast, don't blink' strategy learned from Klein's Alberta.

\section{Public Opinion}

These early cases show that an ideologically coherent strategy was not sufficient for the government to receive public acquiescence or consent. The case studies show that large segments of the public were not, in fact, sufficiently "isolated, individualized, non-unionized and disunited" (Kelsey, 1994:183) to allow the government's restructuring to proceed unabated. This is not surprising, considering that initial public opinion research conducted by the government in the fall of 1995 before its first economic statement exposed the thinness of its support. Early in the survey, the government asks: "What do you think the provincial government's first priority should be?" (Environics, 1995) Of the five suggested answers, three receive virtually the same amount of support: "supporting job creation" at $27 \%$, "preserving services" at $27 \%$ and "balancing the budget" at $25 \%$. Two scarcely supported responses are "cutting spending" at $9 \%$ and "cutting taxes" at $6 \%$. This immediately suggests that the government did not have the mandate for expenditure and tax reduction it thought it did from its electoral victory. Instead of revising its policy objectives or beginning a long-term process of consultations and information dissemination, the government continues to 'push poll' through five additional rounds of forced-choice questions until it is able to construct a majority alliance of respondents to support small cuts to education funding and some cuts to 
municipalities if they were "managed more efficiently". 12 A bare majority agrees to cut income taxes "to get the economy going again" and some public sector jobs, provided "any job cuts... [are] made up in the private sector". The survey never succeeds in obtaining majority support for cuts to health. Its only highly endorsed statements, appearing at the end of the survey, are vague: "large government deficits hinder job creation and hurt business confidence" and "making government more streamlined and efficient may cost some jobs in the short run, but cutting the cost of government will help the economy in the long run" (Environics, 1995). It is therefore not surprising with this lukewarm response from polling, which is a substitute for authentic consultation with the public, that the government takes the "thin democracy" (Atkinson, 1994b:168) approach of moving quickly to implement its non-negotiable goals.

Yet, despite these findings, a public opinion survey conducted immediately after the first economic statement and its promotion by government suggests opinion can be moved. In this survey, after the announcements and subsequent media coverage of substantial expenditure cuts premised on a large deficit, for the first and only time in known polling by this government, "deficit/debt/spending" is the issue respondents felt "should receive the greatest attention from Ontario's leaders today" (Ipsos-Reid, 1995c:3). Further, a majority of the public (54\%) appears ready to cut spending and balance the budget even "at the expense of those least able to afford it" (15).

12 Environics (1995). In addition to standard segmenting by age, gender, education, employment status and household income, this survey also segments by: working women (full-time, part-time or homemaker), union membership (respondent, family member or none), employment by public or private sector, home ownership, region, community size, political party preference, visible minority status and children under 18 years of age (Environics, 1995). 
This public self-interest presents a radical change from the negotiated social compromise that characterized Canadian and Ontario politics before the 1990s and can at least partially be explained by the discourse of authoritarian populism (Levitas, 1986:18), in the form of the Common Sense Revolution, and the discourse of debt that both precedes it and is encapsulated in it. Authoritarian populism draws on popular discontent with aspects of the social democratic state and imposes social discipline as a panacea (Jessop et al 1988; Hall, 1988). As manifested in the CSR, it is a discourse that "create[s] crisis and chaos, then hope[s] voters will opt for strong leaders with simple messages" (Sewell in Boudreau, 2000:22). Its paternalistic disciplining of the 'unworthy' allows citizens to be self-interested without guilt (Edgar, 1986). The counter-discourse of democracy, as seen in these case studies, is liberal democratic in nature and "privileges an individualistic and self-interested vision over one of solidarity and collective action" (Boudreau, 2000:78). Particularly in the Megacity case, "democracy discourse almost equates citizenship with home ownership-tenants and the poor get short shrift" (Keil, 1998:163).

\section{Challenger Communication Strategies}

Against the powerful resources of the state to construct and fine-tune strategies to aid in implementing its policy agenda, the challenger strategies in these case studies rely on a degree of communications expertise, but fewer monetary and legitimative resources. Schlesinger (1990:79) has discussed the ideal-typical conditions that non-authoritative, challenger sources must meet to gain entry successfully to media accounts: a well-defined message that satisfies news values, targeted media for 
message placement, assuring success through awareness of factors that might have an impact on the message and neutralized or anticipated opposition. Schlesinger also foregrounds the extent to which any given source is institutionalized, the financial base available to any given actor and cultural capital or credibility in the shape of legitimacy, authoritativeness, respectability and media contacts. Deacon (1997) focuses on the investment, financial or other resources, that organizations make in their communications efforts. In his study of the voluntary sector in Britain, Deacon (1996:191) concludes that "on a fundamental level, the study confirms a close link between media prominence and economic power". Richer, professionalized organizations have the most media contact and put more investment into communications activities. Deacon's research findings also show that these same groups were the most political in their communications activities and had the greatest prominence in the media. Even when research factors were controlled, there was still a relationship between government proximity (integration of the group into official networks) and media contact (193). This suggests that the most relied on sources have learned to refine their communication messages and strategies in order to obtain media access (Harris, 1989:305; Negrine, 1996:27).

The institutionalized challengers in the three case studies-OPSEU, the municipal tier of government in Toronto and the Ontario Teachers' Federationwere highly organized and media cognizant. The OPSEU communications strategy elicited praise for its professionalism from an unlikely source, Strategy, a public relations newsletter (Rotman, 1997), and the OTF was invited by the Public Affairs Association of Canada to present its strategy at a media panel discussion (OTF, 
1998). A non-institutionalized source, Citizens for Local Democracy, was cited for its electronic advocacy efforts in OnTheInternet magazine (Clift, 1998).

If the test of success for an advocacy group is media coverage, noninstitutionalized sources such as Citizens for Local Democracy and People for Education gained relative media prominence during their challenges to the government, as Tables 4 and 14 show. In general, Liz Rykert of C4LD and Annie Kidder of P4E report easy access to media, although less so in the tight Toronto media market, which, although it has numerous media outlets, also has strong competition from a large population for access (Kidder, 2003; Rykert, 2003). Often, however, they gained access through "stunts", as Kidder characterized some of P4E's early actions. On some occasions, challenger access reflected Golding and Elliott's (1979) “interesting" news (appealing to individual members of the human race), but not "important" news (concerned with institutions and decision-making). C4LD, for instance, received substantial media coverage from its disruptions of the legislature from the public galleries and from the often flowery denunciations of the government by C4LD leader, John Sewell. This type of coverage, however, exists in strong contrast to the calm and authoritative coverage accorded the government spokespersons. As noted in the previous chapter, Sewell's rhetoric was also criticized by the media.

Despite the media tendency to trivialize their efforts, these groups met Schlesinger's (1990) ideal-typical criteria for success and clearly received benefits from strategies that had a strong focus on communications efforts (Deacon, 1996); after all, their very existence emanated from a desire to counter the government's 
agenda publicly. As Deacon's research demonstrates, however, institutionalized sources have a clear economic advantage as well as government proximity working for them in their communications efforts. This imposes a severe limitation on those non-institutionalized sources in attempts to gain media access.

As suggested in the previous chapter, successful media access also depended on credible spokespersons. Those who spoke on behalf of challenger organizations were educated, middle-class professionals who were articulate and knowledgeable not only about their own specific issue, but about politics in general and the media. Their efforts resonated with journalists who shared this background and media reports were geared to an audience with similar values and backgrounds. Although there were variations in tone, style, format and content in each of the three Toronto newspapers, the point is that amalgamation and education had resonance within middle-class space. This is in sharp contrast to the case of the OPSEU strike, where there was little public support for the strikers and no public support groups.

Although the absence of challenger groups that made efforts to obtain media access in order to give a pro-union point of view make it obviously impossible to reconstruct, there is no record of such groups. In the Bill 160 case, which also involved a labour dispute, there was significant public support, but this support was for a credible and respected professional group (teachers), rather than a group of unionists. Clearly, successful access to the media has determinants other than class and education, and unionism is one such factor. The only expression of labour points of view is related to the Days of Action, which were also marginalized by the media. 
Deacon and Golding (1994) go beyond the issue of accessing the media and raise the issue of how challengers sustain media interest. They suggest that public actions may bring issues to the forefront of the media agenda, "this influence was largely transient, as journalists quickly tired of these performative gestures, and looked for other issues to sustain their attention" (195). Yet limited resources can prevent groups from campaigning on more than one front. Kidder reports that the body of education research built up by People for Education since 1996 has increased the credibility of the group with the media (Kidder, 2003) and, presumably, has increased its flexibility in taking action or reacting on educational issues of importance as they emerge. Where it was once run completely on volunteer labour, P4E currently has two full and five part-time staff and a budget of $\$ 350,000$ per year (Kidder, 2003).

As has already been discussed, challenger groups such as Citizens for Local Democracy and People for Education work within the alternative meaning system, on civil terrain that is more or less hospitable but certainly open to their messages. Oppositional groups, however, by definition do not have regularized relations with either government or media and rely on disruptive access to bring their point of view to a larger public through the media. These case studies have demonstrated that the line between alternative and oppositional meaning systems is permeable, in keeping with William's (1977) view of emergent and residual meaning systems as part of an active process rather than as fixed categories. Through its discursive strategies and policies, the government challenges the legitimacy of any opposition and attempts to limit or marginalize it. Visible, single-issue opposition may, in fact, 
have given the government the opportunity to show the wider public that it was defending the province's general interest (Noel, 1997:14). This serves to point out the advantage to the government of the absence from media reports of sustained, contextualized coverage on the Days of Action, which was led by a coalition of social justice groups and unions. In this way, union members, urban Toronto residents, parents and teachers have been characterized as "special interests" and "radicals". The truly oppositional challengers are completely absent from media accounts and rendered voiceless, unless such accounts confirm perceptions that they are on the outskirts of society. ${ }^{13}$

In this repressed and polarized public sphere, the media made daily news judgements. At times of heightened government activity, such as during blitzkriegs, their judgements were conditioned by primary definition and institutional accommodation. As concerns 'radicals', to use the government's characterization of challengers, a glaring omission in media coverage over the time of the three case studies in this thesis has been the lack of contextualized media reports on resistance to the government, particularly in the case of the rotating Days of Action.

\section{The Days of Action and Resistance}

The Days of Action were "a visible and militant" (Rapaport, 1999:59) antigovernment strategy sponsored by organized labour, through the Ontario Federation of Labour, and social justice groups across Ontario, through the Ontario Coalition

\footnotetext{
13 A recent example would be the media coverage of the trial of three members of the Ontario Coalition Against Poverty, charged with inciting a riot during a demonstration at Queen's Park three years ago (OCAP, 2003). In May 2003, the trial resulted in a hung jury, but the Crown decided to retry the case against OCAP leader John Clarke.
} 
for Social Justice. The actions strategically moved resistance away from both the perceived 'self-interest' of middle-class-only and labour-only opposition to the government into organization of a broader coalition of interests and escalating actions (Munro, 1997:125). The eventual goal was understood to be a general province-wide walkout.

Middle-class activism, as it developed in these case studies and in the first half of the government's mandate, was transitory and single-issue driven (Boudreau, 2000:122), as well as "status-securing and conservative in purpose and effect" (Keil, 1998:163). Although powerful when in campaign mode (Rykert, 2003), such activism tended to be unpredictable and unsustainable. Labour activism, on its part, was marginalized by the public and the media, as the OPSEU case study showed, and perceived as too powerful (Ipsos-Reid, 1996d), but it was organized throughout the province and well-resourced. The Days of Action offered a framework for action that would build an organic, grass-roots bloc with the organizational and financial resources to ensure success_ a "collective political expression of workers" groups and other progressive political organizations that could have a more sustained impact on what Gramsci called 'civil society”' (Munro, 1997:127).

Munro writes that the actions strengthened the social justice movement, shared organizing expertise, brought direct action into the mainstream of politics and bolstered a climate for debate and further opposition (127-30). They were heavily reported in the communities where they were held, although not necessarily positively. Although the first action in London in December 1995 attracted up to 15,000 protesters and was deemed a successful show of unity, tensions within 
organized labour were immediately evident, as different perspectives emerged on how to fight the government emerged (Turk, 1997:168-9). The split revolved around two schools of thought. One view, held by public-sector unions and many community groups, was that change was only possible "through the building of a social-based movement that would hold any party or government accountable" (172). The other view, espoused mostly by the private-sector unions, questioned the influence of such actions and believed that "social change only comes through the ballot box" (173). This rift became stronger as the actions continued and those who supported an electoral approach did not see support rising for the NDP, the political party on which it rested its hopes (171-2). Because of this internal dissension, the Ontario Federation of Labour, the primary union in the coalition which had spent $\$ 164,000$ in total on the first two Days of Action, limited its contribution to staff time only for the remainder of the actions (170).

Internal dissension was not confined to the labour side of the coalition, however. The Metro Network for Social Justice (MNSJ) was also experiencing "conflict over its role and prominence in movement politics", which some felt would come at the expense of "meaningful debate over vision, strategy and organization" (Conway, 2000:44). The MNSJ had emerged in the struggle against free trade, becoming a formal organization in 1992 and growing to include almost 250 member organizations (45). It was "one of the largest, most innovative, and best-functioning examples of a new political form...; the permanent, cross-sectoral, multi-issue social justice coalition" (45) and it positioned itself consciously as working for the "formation of organic intellectuals" in a war of position (43). After 
the election of the Conservative provincial government in 1995, many of its member groups came under financial pressure, while individual members were becoming more "politically radical" (44-45). As with the labour movement, much of the internal debate in MNSJ came down to a conflict between 'action' and 'education' (62). Conway concludes that while its work has continued, "it no longer threatens or promises to transcend the boundaries of coalitions as we know them" (64).

This conflict between competing notions of how to build and achieve counter-hegemony proved insurmountable for labour, and the action days, although they continued, did not culminate in a province-wide political protest. For the first action in London, media coverage was national, but by the second action in Hamilton, coverage was limited to prominent reports in that city's media. ${ }^{14}$ For the third and subsequent actions, coverage was isolated to the city where the action took place (Mittelstaedt \& Rusk, 1996:A6; Macleod, 1998:3,4).

The sole media report that referred to a "fledgling social movement" was at the time of the Toronto actions (Mittelstaedt \& Rusk, 1996:A6). The report laid out succinctly the problem ("Ontario is becoming a much more polarized place"); the challenger position ("This is really trying to build a grassroots movement"); and the Premier's in response ("Union leaders like the total control of the agenda and their members that they had more under Bob Rae"). But the report also indicated that such protests as the Toronto actions "typically appeal only to those who already agree with the action", that "opposition groups have not been able to offer the public a clear and workable alternative" to the government and that "one of the next

\footnotetext{
14 This was confirmed in a media search.
} 
challenges [for the opposition] will be to get the provincial and national media attention needed to mount a bigger or more novel event than the preceding protest" (A6). This report was notable because of its uniqueness in providing context for the action taking place, using expert opinion and quoting the position of the challenger leaders. It did, however, suggest that the Toronto action was "organized primarily by unions", although the challenger quotes hinted broadly at the development of a broader movement that would create alliances that would act beyond the provincial environment. It also presented the challenger position as emotional ("euphoric"), while the expert's opinion was characterized as rational ("cautious") and the Premier's response was authoritative ("highly partisan rhetoric") (A6). The report did correctly hypothesize that "short of a province-wide Day of Action there appears to be little on the horizon that would draw similar [media and other] attention" (A6). The only general media coverage was when labour first indicated it would move towards a province-wide strike (Mackie, 1997:A1) and when it eventually decided not to go ahead without full support of all union participants (Mackie, 1997:A3). The latter decision prompted a Toronto Star report that called it "the most under-reported story of the past week" (Urquhart, 1997:A17). Interestingly, the media silence on the Days of Action echoed the silence of the government. Other than a comment by the Premier in a speech to the Conservative convention that took place in Hamilton during the action in that city, and despite the easy primary definition we have seen accorded the government, Premier Harris and his ministers do not have a presence in the few media reports on the actions. 
Unlike the isolated and single-focus protests of the three case studies, the Days of Action held the potential to foster an organic social movement, a fledgling historic bloc, that could have "crippled the province and forced a crisis severe enough to require either a compromise or an election" (Ibbitson, 1997:209-210). In a Toronto Star op. ed. piece, James Laxer (1996:A15) called the Toronto Days of Action a "broadly based, diverse social movement" that reflected the belief of its participants that "efforts to moderate the Tories through normal means, such as lobbying and debates in the legislature, are a waste of time". Internally, however, action organizers did not have a clear, alternative vision (Turk, 1997:175), strategy or structure "to take advantage of the impressive local spaces opened up by the protests" (Gindin, 2001:97). Their efforts were also hampered by their inability to sustain or diversify resistance in the communities in which the actions took place (Munro, 1997:133). The OPSEU strike, for instance could have prompted support strategies by labour and social justice groups in key communities "to make the links between OPSEU demands and the larger issues, such as cuts to public services, that their struggle entailed" (133). After a gap of six months, the last of the 11 formal actions was held in May 1998 in St. Catharines. ${ }^{15}$

Labour unions against continuing the Days of Action did not believe the actions were making a difference, yet several indicators point to the opposite assessment. First, two public opinion surveys released publicly within days of each other at the time of the Toronto action in October 1996 showed that the public felt sympathy for and interest in the protests. Environics found that nearly six out of 10

15 A "day of picketing" was held in Ottawa in October 1998, but it was not an official Day of Action. 
of those polled "identif[ied] at least somewhat" with the protesters, which the polling company itself found high (Mittelstaedt \& Rusk, 1996:A6). In a survey of Toronto residents after the first day of that city's two-day protest, Ipsos-Reid (1996e) found that $55 \%$ felt the action meant the government "should reconsider some of its policies" (Globe \& Mail, 1996:A3).

The second indicator is the leak of a new government communications strategy to the media in January 1998, just after Bill 160 was passed and three months after the $9^{\text {th }}$ Day of Action. The draft strategy-or partial strategy, as the leak only contained the message and tactics portions of the document-was written by an aide to Premier Harris in an effort "to shed the 'evil image' that [Minister Chris Hodgson] says the media has attached to the Tories" (Brennan, 1998:A4) and to repair what the media report called the "tarnished reputation of the Harris government in various quarters" (A4). The timing of the strategy suggests that the government was attempting to regain control of an agenda that was pushed off course by resistance efforts.

Third, as Figure 5.1 demonstrates, when the changing levels of support for the Ontario political parties are graphed along with the dates of the case studies and the Days of Action, troughs in Conservative support occur at these times. This is more evident when the Days of Action occur closer together. When there is a gap in time before and after the last two actions, however, there is little impact on party support, indicating that the building momentum of the actions was lost. ${ }^{16}$ It is

16 Despite the declining support, it must be said that "the Harrisites remained more popular than is usual for governments at mid-term and well within striking range of a repeat victory in the next election' (Noel, 1997:11). 


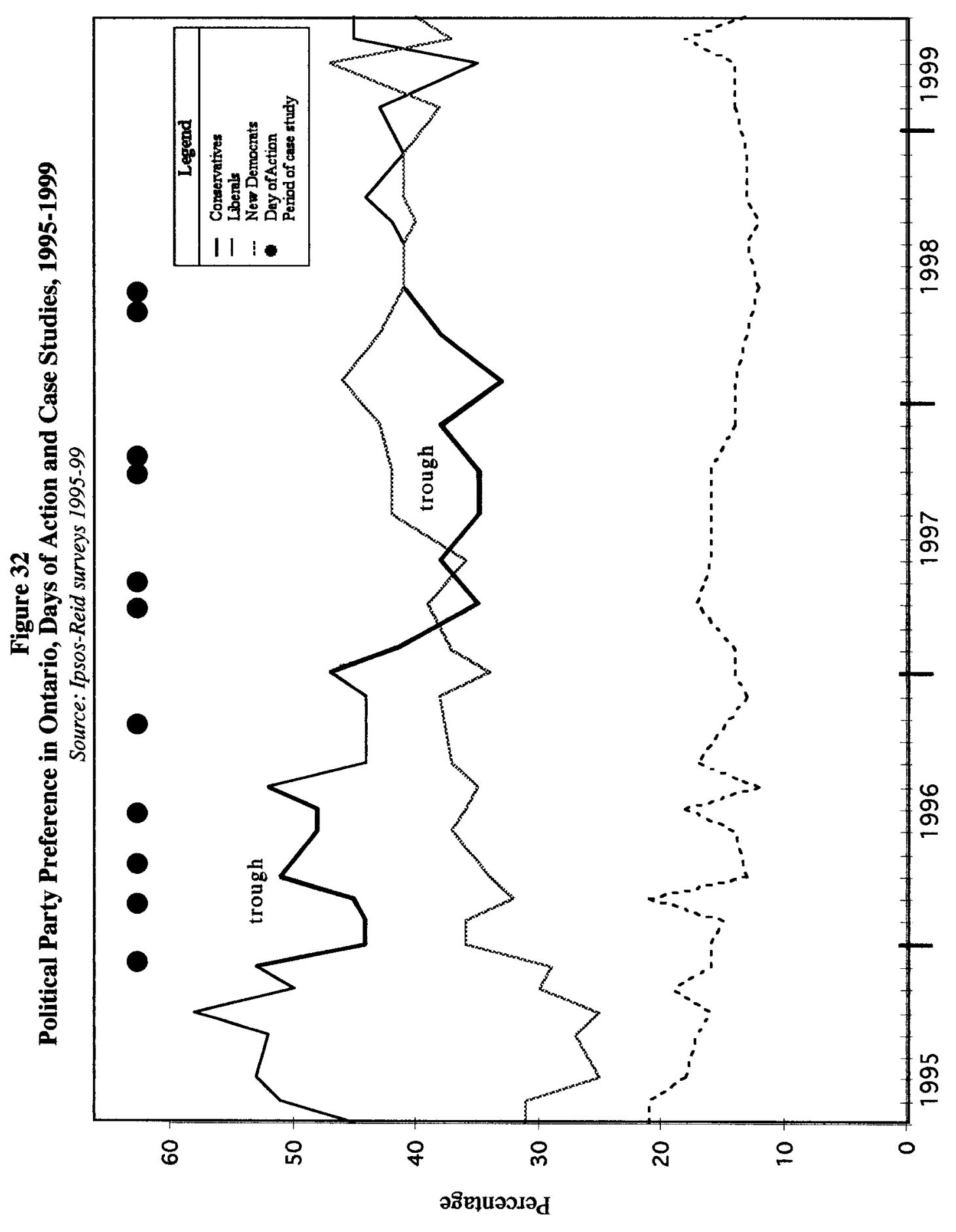


important to note here as well that the Harris government's intense legislative and policy onslaught meant that there were many overlapping spheres of action resistance taking place. Figure 5.1 only graphs the three case studies in this thesis. As an example, as indicated earlier in this chapter, the TVO campaign was taking place during this transitional time period as well.

Fourth, a lengthy feature on the Harris government appeared in The Globe \& Mail on November 1, 1997, in the middle of the teachers' walkout on Bill 160. Titled "The Harris Revolution: Inside Ontario's Revolutionary Politburo", the front of section analysis featured a half-page photo of the Kremlin flying the Ontario flag with a head short of Premier Harris superimposed on the background (Crittendon, 1997:D1). The story lauded the "successful insurgency" of the new government, but heavily criticized the "unprecedented centralization of power" within the Premier's Office. The feature concluded that the premier "could be in trouble in the next election if he doesn't recognize that the revolution is over and take steps to fundamentally reform his central-planning style of government" (D1). Although the article would have had limited interest for and impact on the general public, the business elite in Ontario and throughout Canada was concerned that it was not benefiting to the extent it had expected from the Harris government market reforms, at the same time as it would not have failed to notice the opposition the fledgling neo-liberal project in Ontario was encountering. In other words, criticism of the government now was coming from both its supporters and its detractors. One can speculate if the concern was expressed after the article was published or through the article. Taken together, the polls, the new strategy, the graphing of resistance and 
the Globe article demonstrate a sustained impact of the opposition on the government's credibility.

Government and media silence on the Days of Action as linked to other resistance, such as the case studies here or vice versa, cannot be explained by invoking news values; the actions no doubt prompted questions and a desire for information from the broader public and the government no doubt had many opportunities to comment or elaborate on the significance or lack of importance of the actions. It is not credible, given the extent of primary definition and institutional access that we have seen in these case studies, that the media would not seek comment from the government. The silence instead suggests that the government was aware that the actions were having an impact (confirmed by the leaked government communications strategy) and a choice was made not to engage. In the Globe, for example, government spokespersons were cited only seven times in 17 stories, with the only lengthy comments provided by Leslie Noble, a Conservative campaign co-chair (Mittelstaedt, 1996:A1). Total Globe coverage for all the remaining Days of Action consisted of seven stories, six of them only one paragraph in length.

For the government, silence would have been a strategic move, especially early in their mandate when there was doubt that the actions would continue. ${ }^{17}$ For the media, it would have been a practical move to avoid the costly and lengthy process of preparing 'think' pieces that would widen the range of issues related to

17 A recent news report, in fact, indicates that the strategy of the Harris government is that protest helps its re-election chances: "As we saw in 1999 when they started protesting like this and you get the people with the funny hair coming out and protesting... it's not necessarily a bad thing", according to current Conservative campaign manager, Jeff Bangs (Lindgren, 2003:A6). This confirms that silence was indeed a strategic tool of the government. 
the ongoing resistance, but the government's silence would also have signalled to them that the actions, as with any other opposition the government had encountered, were not viewed as credible or significant-merely a larger group of self-interested radicals. As Deacon and Golding have written (1994), "[t]he power to create and distribute meaning still resides with centres of material and political power" (203). An organized, resourced and united opposition would have posed a significant challenge to the centres of power.

The Days of Action exist in high contrast to the Conservative government's implementation of its neo-liberal agenda. While in opposition, the government conducted a limited war of position, in Gramscian terms (Gramsci, 1971). It successfully organized an alliance with a common worldview and slowly expanded its hegemony, building in effect a historic bloc at the same time as it planned to. transform the state (Simon, 1982:28). It began by organizing internally within the Conservative party, then selectively consulting the citizens of Ontario (through public opinion research), building an election platform that reflected the "hotbutton' issues that resonated with citizens and promoting the platform in order to gain consent (Woolstencroft, 1997b). The election of 1995 illustrated the unforeseen, dramatic political change that can occur when a war of position is successful. After the election, the government did not maintain its organic character, but moved to a "two nations" strategy (comprising the worthy and the unworthy) that Jessop (1983:104-105) sees as a point on a hegemonic continuum between the expansive, consensual, 'one nation' project of Keynesianism and the politics of exclusion of authoritarian 'two nation' regimes. 
The Days of Action represented a quite different approach. Resourced from above (through union donations) and organized from below (at the community level by social justice activists and local union members), they were organic expressions of resistance to the government. Their challenge was to the discourse of debt reduction as primary societal focus and its "there is no alternative" prescription. As union activist Sam Gindin said after the first Day of Action (Watson 1997:141-142),

[t]he London protest was the first time during any of our lives [in Ontario] that workers in mass walked off the job over social issues... Something beyond numbers was happening. Something that had to do with political consciousness. Workers were saying that they were no longer content to leave politics to the politicians... London was the beginning of a new politics in which workers... would take dramatic action to focus attention on the kind of society we were becoming.

The Days of Action were the opposite of Gramsci's "passive revolution", laying groundwork for a limited "active democratic revolution in which the masses and not the state, play the fundamental role" (Mouffe, 1979:13). The cross-picketing and other mutual support went beyond a single issue and a single group of workers and instead entered a process that followed Gramsci's $(1971: 181)$ relation of political forces: from the group solidarity of those in the same job (the economic-corporate level) to the economic solidarity of those with similar jobs (still at the economiccorporate level) and then to the economic-political unison and intellectual and moral unity of a whole class or group (at the most purely political level).

But, despite the heady optimism brought by the first actions, the political strategy of the actions was never clear (Munro, 1997:135). Unlike a labour strike, with its concrete demands and limited frames of reference, the question "what were they building towards?" wasn't necessarily "a province-wide strike", but a broader, 
deeper formulation of resistance that was not articulated. This was evident in the rift between those unions that wanted to focus on the formal political process and those that sought to build a social movement that transcended it (Turk, 1997:172-3).

The actions were flawed in one other critical way: they did not successfully link to other organic struggles, such as the OPSEU strike and the fights against amalgamation and Bill 160. Neither the participants in these struggles nor the media coverage of them made the linkages between these individual cases and the larger resistance. Only the Hamilton Days of Action, which took place just prior to the OPSEU strike, were seen by the media to segue to the strike, but they were treated as a self-standing, newsworthy event rather than contextualized within a larger framework. Although a counter-discourse was thus nominally present in media coverage, it was in the form of "scattered facts" and did not "construct an equally salient argument" (Entman, 1993:57) against the dominant discourse.

\section{Conclusion}

The case studies in this and the previous chapter reveal some of the processes, limits and opportunities in ideological reproduction. State policy success relies on the ideological and political cohesion of the government, aided by bureaucratic communications operations that are increasingly geared to persuasion and legitimation which privilege the government in power. Routinized media operations echo bureaucratic structures and privilege the dominant media system as represented by the government in its institutional accommodation. The increasing importance of persuasion techniques such as advertising coincide with the commercial logic of 
media institutions, which also have an interest in the status quo and have the power to construct and reflect preferred meanings.

Through its restructuring strategies, the neo-liberal government laid the foundation for unprecedented control of the means of legitimation by a government in Ontario. In these case studies, for instance, the government curtailed public consultations and demonized public outcry as self-interested and radical. It also used its electoral majority to pass controversial legislation swiftly to avoid media and opposition scrutiny, thus increasing the likelihood of media dependence on its framing of issues and decreasing the likelihood of opposition.

These case studies take place within a shifting media environment of convergence which corporatizes and commercializes media operations. The three Toronto newspapers that have provided the content for analysis of these cases have changed ownership since the 1995-1997 period. News operations now have different imperatives that include maximizing profit which has an impact on media content. A study by NewsWatch Canada and the Campaign for Press and Broadcast Freedom on media concentration in Vancouver confirmed "a lack of political diversity and balance", with progressive or left-of-centre viewpoints (alternative or even oppositional voices) "regularly neglected, particularly in commentary on politics and public policy issues" (Hackett with Glustein, 2003:1). In the three case studies examined in this thesis, the absence of in-depth reports that would have provided information and context on what was widely considered within social groups in Ontario to be a bourgeoning resistance to the Harris government has been noted. But the NewsWatch study is a reminder that coverage in commentary or in- 
depth reports would not necessarily support alternative or oppositional points of view. It is difficult to pinpoint if the absence of commentary or features on the Days of Action was ideologically motivated or reflected practical limitations on reporting, or both, but the fact remains that at a critical 'moment', in the Gramsican sense, in the transition from one paradigm to another, the main Toronto print media were silent.

There is, however, a danger in overstating the strength of neo-liberal projects (Williams, 1983; Levitas, 1986) as they overwhelm policy and legislative agendas and keep the opposition off-balance fighting on different fronts. When Deacon and Golding (1994) refer to the government's "power to create and distribute meaning", they add, "but this power is exercised dynamically. It is fought over, challenged, and abused, both within and without" (203). Thus, the extent of organized and resourced opposition is also a factor in government policy success or failure. As we have seen in this and the previous chapter, despite the considerable and increasing power of the government in coercively gaining the consent of Ontario citizens, "there is a distinction between success and domination" (Bruck, 1992:141). Although the government was successful in its legislative agenda of restructuring, resistance showed that it did not dominate. The retreat on the privatization agenda, a major policy plank of the Common Sense Revolution, showed the limits to state domination.

Bradford (1999) suggests there are two key contexts that must be arrived at for a new policy paradigm to be said to be governing. The new paradigm's philosophy and technical model must achieve consensus in expert ideas and in 
socio-political interests (the inculcation of the new paradigm through the political system). The Harris government had sufficiently achieved consensus in expert ideas prior to the election, but it had yet to achieve it in socio-political interests. Already an intense time of transition, the government's swift moves to implement its restructuring agenda may have overestimated the available capacity to embed a radically different paradigm into the political system, let alone the capacity to legitimate it or the capacity of the public to absorb it. Gramsci contends that a ruling hegemony must achieve hegemony over both civil and political society for it to be complete (Simon, 1982:26). By the end of 1997, the Ontario government had won political but not social legitimacy. Instead, it had achieved domination and a transient consent, but the 'success' represented by hegemony remained elusive.

Through these case studies, this chapter has examined the elements of hegemonic communication-that is, political communication used hegemonicallyin contributing to the emerging hegemony in Ontario. It has demonstrated that at times of major economic crisis the competing demands of liberalism and democracy can become irreconcilable. Attempts to deliver a radical liberal programme within an elected, representative democracy give rise to "a paralyzing contradiction between the needs of capital accumulation, served by liberalism, and of legitimation, served by democracy" (Kelsey, 1994:180). The imperative of capital is visible throughout the case studies, both figuring prominently in government messages and as a prerequisite for resourcing legitimation efforts. It is reaffirmed as an underlying ethos in the leaked communication strategy of January 1998, which ends the period covered by this thesis. That strategy re-emphasized the importance 
of "becoming the best jurisdiction in North America", "mak[ing] our province the envy of the world" and "bring[ing] prosperity to Ontario" (Brennan, 1998:A4).

In moving forward at this early stage of its neo-liberal agenda, the government with few exceptions placed its ideological objectives before its political interests, eschewing conciliation and risking "a continuing parade of allegations, the creation of confusion on complex issues and the accumulation of determined enemies" (Tiffen, 1988:33). When the federal government was faced with economic crisis and the emergence of neo-liberalism as an ideological and corporate influence, it offered "concrete legitimacy" in the form of concessions to the holders of the incoming paradigm in the attempt to stave off the legitimacy crisis (McBride, 1992:23-4). The new Ontario neo-liberal government in the same situation of strong opposition instead proceeded with its agenda without modification or major concession. Its "remaking of common sense" (Hall, 1988:8) faltered because it considered that the ideological force and cohesion of its agenda would be sufficiently powerful to achieve its goals without consensus politics. The government severely underestimated the (growing) strength of opposition to its policies, but, as the media mapping of the case studies demonstrates, it nonetheless found support in media accounts that privileged its points of view. As Negrine (1996) points out, "there are occasions when the press simply ignores public sentiment, but this is unlikely when at the same time there are divisions in government. It is that combination of public and political dissent which is significant" (115). This was the case here--there was opposition both in the legislature and on the streets throughout this period and individually in the case 
studies-yet the media were often slow to recognize which of the many government initiatives in motion deserved further scrutiny. The government's blitzkrieg approach successfully diverted the media, just as it had divided and confused the public, thus mitigating the impact that "public protest aided and abetted by a doubting media" can have (115). The government was able ultimately to push its controversial policies out of the "differential visibility" of the public and media eye and into the "invisibility of implementation" (Tiffen, 198:189). The decision of labour and social justice groups not to hold a province-wide strike should be considered a lost opportunity to capitalize on the "negotiations over meaning" in which it had been participating, unequally, but with some success (Phillips, 1996:214). A "substantial, powerful and articulate social sector able to disseminate its own highly cogent and increasingly assertive world view", in the analysis of Golding (1992:519) on the failure of the poll tax ideological offensive in Great Britain, could have "significantly limited... the opportunities for a hegemonic triumph" by the government, but the moment was lost.

With this in mind, the next chapter will discuss the resilience of the Ontario hegemony, the possibilities for the constitution of a counter-hegemonic project and the role of communicative democracy. 


\section{CHAPTER 6: COUNTER-HEGEMONY AND \\ COMMUNICATIVE DEMOCRACY}

\section{Introduction}

Using a Gramscian perspective, this thesis has examined the political and ideological phenomenon of neo-liberalism, its philosophical origins, its first manifestations in Great Britain and New Zealand, the influence of the US Right on its growth and strength, and the conditions under which it appeared in Canada, first in Alberta and then in Ontario. Using the experience of Ontario as an example, the hypothesis of this thesis is that communication plays a key role in manufacturing consent and building and maintaining legitimacy for the neo-liberal project. This was demonstrated specifically in three case studies centred in the first years of the neo-liberal project that emerged in Ontario in 1995.

In this final chapter, this thesis will briefly revisit the main lines of discussion from the previous chapters and then examine the depth and durability of the neo-liberal project in Ontario and the resistance to it before exploring possibilities for a transformative counter-hegemony within which communicative democracy could be expected to develop.

\section{Neo-liberalism as New Polity}

As Girvan (1994) has shown decisively and as has been demonstrated in the jurisdictional examples in this thesis, a new wave of conservatism in the form of neo-liberalism continues to dominate as a philosophy and in political practice in 
Western industrialized nations. Extensive programs of restructuring by neo-liberal governments have transformed the Keynesian compromise that prevailed in the post-World War II era into a new polity characterized by its economic "leanness" (Sears, 1999), if not by its social 'meanness'-what Kelsey (1995) has termed its social deficit.

Neo-liberalism promised a way out of the economic uncertainties of the 1970s and 80s that saw Keynesian-influenced government economies unable to cope with simultaneous high inflation and high unemployment while maintaining social services and a high debt load. Not coincidentally, the situation also saw a decline in capital accumulation and capital's interest coalesced around neoliberalism in order to "restore profitability to the capitalist system" (Warnock, 1988:34). The New Right's response, first in Great Britain as a reaction to that nation's specific historical, economic and political situation, and then later elsewhere, was to construct an ideological discourse of crisis that, drawing on both the moral conservative and laissez-faire liberal strands of neo-liberalism, was authoritarian and populist and grounded in the mantra of TINA that 'there was no alternative' but to follow a neo-liberal course of action which would re-establish competitiveness and stability through market liberal policies that were flexible and would allow for unregulated trade internationally (Albo, 1995:107).

Ideology, at its most forceful, works invisibly and neo-liberal discursive strategies of crisis and TINA have worked with success to embed a new common sense into social, economic and political relations wherever they have been encountered. Neo-liberalism is thus able to present itself as natural and acting in the 
neutral general interest of all, while "draw [ing] its social power from the political and economic power of those whose interests it expressed" (Bourdieu, 1998:2). As the profiles of other jurisdictions and the case studies have shown, this is not an uncontested process.

Although neo-liberal governments have indeed balanced budgets and deregulated as promised (although for some, like the US, balanced budgets have not been sustained), their track record in other areas is less inspiring: "The postwar golden age of full employment capitalism has become a leaden age of falling working class living standards, declining public services and social polarization" (Albo, 1995:107). The real crisis, it seemed, was between the "competing demands of liberalism and democracy" (Kelsey, 1994:179-80), which marked a delineation between the economic demands of neo-liberal capitalism and the integrated economic-social demands of post-war compromise capitalism. For the many who do not benefit from the capital-led transformation of the political economy to the new polity, neo-liberalism marks "the erosion of social programmes that have effectively driven down wages, exacerbated poverty, and generally created profound feelings of vulnerability and anxiety" (Workman, 1999:82). ${ }^{1}$

By "severing the economy from social realities" (Bourdieu, 1998:2) and privileging the economic over the social, neo-liberalism also

minimizes social pressures on the state by: dismantling or distancing itself from welfare and corporatist institutions; narrowing and redefining the range

\footnotetext{
I Much of this is revealed in the "Ontario Alternative Budget" papers, a project of the Canadian Centre for Policy Alternatives. The OAB uses different indicators than the Bank of Canada to illustrate, for instance, how programs and capital spending in Ontario are the lowest per capita in Canada (see chart 1 of the OAB) while tax cuts have weakened Ontario's revenue base (see chart 2).
} 
of legitimate state actions; and re-orienting popular expectations about the role of the integral state in the governance of economy and society.

This new economic determinism shifts members of society from their role under liberal corporatism as citizens or those in need of help and towards an economically constructed role as client, customer or taxpayer (Isin, 1998:176). In effect, neoliberalism has redrawn the boundaries of citizenship, in the belief that "a fiscally responsible state should not be expected to respond to 'special needs' or 'special interests" (Workman, 1999:82)—even if those needs and interests are those of citizens. It thus removes the state as the site for democratic claims (Harder, 1996:59) and works to disempower citizens from representation and participation in civic life. Social policy itself is "restructured so as to link it to the requirements of the capitalist labour market" (MacBride, 1996:75), further subordinating the social to the economic.

It is important to recall that this forced separation of two highly embedded spheres of society (Polanyi in Boudreau, 2000: 85) is not a haphazard byproduct of an individual political party's agenda, but instead is constructed within the international intellectual community consciously in order to counter the "explosion of social interaction, and correlatively a tremendous increase in social pressure" (Crozier, Huntingdon \& Watanuki, 1975:13) in civil society around the world - an excess of democracy, as it were-that the Trilateral Commission believed was a threat to capital (Robinson, 1996a:635). In addition, it is a characteristic of classic liberalism that political society or the state proper is distinct from civil society, while Gramsci theorizes the two as comprising "a historical dialectical totality" 
(Augelli \& Murphy, 1988:132). The separation or integration of economic and social spheres thus represents a fundamental clash in ideologies.

The separation of the economic from the social sphere is one of the most contested aspects of neo-liberalism in those Western industrialized countries that have experienced social, cultural and democratic advancement in the past-war years, but it is not the only point of disillusionment with and struggle against neoliberalism. In the economic sphere itself, "neo-liberal hegemony is fragile and vulnerable because it can't deliver on material prosperity" (Klein, 1996:5).

Although the time-frame of this thesis is the 1995-1997 transitional period in Ontario, it is difficult to ignore subsequent political developments that have already played a role in re-casting neo-liberalism. By 1999, for instance, the federal economic environment, which preceded Ontario-albeit cautiously by stealthdown the road to neo-liberalism, demonstrated that

[i]n economic terms, it is becoming more and more obvious that a program confined to balancing budgets, reducing the size of government, and cutting taxes is not the panacea the neocons made it out to be and was, in fact, to blame for aggravating other problems in Canada's cherished public health care and education systems. New right economics has proven to be good at solving the fiscal problem. But it has not done anything to upgrade the quality of Canada's workforce or move the country along the way towards the knowledge-based economy of the twenty-first century... (DeMont \& Lang, 1999:36).

Just as the neo-liberals pronounced that Canada (and Ontario) had 'hit the debt wall', had their economic agenda hit the wall as well? Communication Canada public opinion research confirms revived interest in health, education, jobs and quality of life issues over concerns about the deficit and the economy that characterized the public's top-of-mind issues until the mid-1990s (CC, 2002). This 
did not prevent the citizens of British Columbia, however, from electing a neoliberal government in June 2001; their traditional electoral volatility and practical political need for a change in regime outweighed any concerns about the election promise of the program called "A New Era for BC begins in 90 Days".

Quite apart from its economic policies, neo-liberalism itself contains contradictions between its two philosophical streams of moral conservatism and market liberalism that might cause it to implode. Liberalism has an individualistic ethic, applies the concept of freedom universally and sees the market as a liberating force, while conservatism has an ethical conception of the moral good, sees limits to individual freedom and the market as a disciplinary force (Girvan, 1994:218).

Moreover, the tension between moral conservatism and market liberalism may already be in intense conflict in the wake of the September 11, 2001 attacks on the United States. Real crises-not the manufactured crises that have precipitated some neo-liberal regime change-may be beyond the capacity of neo-liberalism, according to Beck (2001:25). The shift towards authoritarianism and increased security that it implies is a direct challenge to the market freedoms that are important to neo-liberalism. The "trans-national co-operation" that is intended to protect might instead "become a means of creating fortresses, states in which both the freedom of democracy and the freedom of markets are sacrificed on the altar of private security" (25). This lends credence to Jessop's (1983:105) sense of hegemonic projects on a continuum in which some projects may be transitional and merely prepare the ground for a new period. The new period may be authoritarian

2 The one-page document makes specific promises to initiate dramatic restructuring within 90 days of being sworn into office (BC Liberals, 2001). 
neo-liberalism. If so, any counter-hegemony may involve the unlikely alliance between social movements and state neo-liberalism against global authoritarianism. It may be true, as Carroll and Coburn suggest (2003:99), that "the institutions of the post-war eras, themselves the provisional outcomes of past social struggles, weigh heavily on neo-liberal efforts to recreate a new world order and a new order in Canada. In the process, new contradictions emerge, as well as opportunities for neoliberalism's opponents."

Internal cohesion might be difficult for neo-liberals to maintain, but external cohesion also poses difficulties if they continue to choose ideology over pragmatism: "In fact, popular consent requires both ideological hegemony and material concessions... the failure of the neo-con project to concretely incorporate the interests of subordinate classes undermines its ability to exist 'virtually unnoticed' on the ideological front" (Klein, 1996:15). Ideological success requires invisibility and naturalness, while its failure can provoke contestation and resistance. The three case studies, with their rising levels of resistance, and the TVO example show that ideological reproduction is not inevitable, despite the considerable legitimation forces of the state. The pragmatic response of the government to the continued resistance to its privatization agenda illustrates both that ideology offensives can fail (Deacon \& Golding, 1991) and that effective resistance can delay, curtail or derail them. Neo-liberalism, with its "free economy" and "strong state" needs to continue to find "the right balance between force and consent" (Gamble, 1993:39) if it is to continue to be a defining ideological, political, social and cultural force. 
Ideological failure, coupled with economic failure, can create space for challenges to authority that are not mitigated by the "old stabilizers" of corporatist society. The continued success of neo-liberal governments may depend on their ability or capacity to manage change and disorder as a regular feature of the state (Girvan, 1994: 218). Success may also depend on Klein's “material concessions", but the interests that have participated in the construction of the "the strong state" and that have prospered under it will not likely make such pragmatic compromises easy for neo-liberal governments to make, even before the "open for business" ethos of the Harris government. Under the current market-driven neo-liberal government, which has declared the province "open for business" (Ralph, 1997:177), it is hard to imagine what could induce business to cooperate or negotiate with labour or other non-business interests, but they may not be required to: with sufficient state power now resting in the centripetal state (Golding, 1990), "contradictions may be a strength rather than a weakness, enabling the New Right to switch the grounds of its legitimation at will" (Levitas, 1986:11). But it is also possible, if consent consistently takes its coercive form in legitimation processes, that consent will not be organically grounded in everyday life and eventually pose a danger to continued viability of the government.

The cumulative strength of a neo-liberal project is difficult to judge. Whether these governments saw their initial electoral victories as setting a goal to attain or a mandate to implement (Neilson, 1998:53), they were nonetheless able to amass a "favourable balance of forces" that was sustained "long enough to render [their projects] plausible" (Jessop, 1989:291). In Great Britain, as has been 
recounted in this thesis, conditions specific to each election favoured Thatcher's government, most obviously in 1982 after the success of the Falkland-Malvinas war; this despite the obvious failure of the government's economic policy (Gamble, 1983; Miliband, 1985). When the government changed hands in 1992, it was to a renewed Labour Party that espoused what was called "the third way", a less ideological but not uncontroversial resurrection (Red Pepper, 2002:22-25) that did not reverse the restructuring. In New Zealand, the neo-liberal government was reelected due to structural conditions in the polity that did not have the "checks and balances" (Nagel, 1998:241) that would have prevented a small number of people with power within the system from a virtual Parliament-sanctioned coup. When that government changed hands, the National Party continued with the reforms unabated (Scott, 1996). Both countries benefited from the fear and uncertainty engendered in the discourse of TINA - 'there is no alternative'. Similarly, Ontario's government was re-elected in 1999 under its own specific conditions: a traditionally weak partisan political opposition, split between two parties, was unable to counter the persuasive 1999 election campaign platform, "Blueprint: Mike Harris' Plan to keep Ontario on the Right Track"-a message from the government's ongoing public opinion research. ${ }^{3}$ As the Ontario re-election experience, and indeed the evidence from the other jurisdictions, has shown, communications systems and media

\footnotetext{
${ }^{3}$ In public opinion research throughout its first mandate, the government consistently asked a version of the question "do you think the government is on the right track or headed in the wrong direction?" Even when polls showed the Conservatives trailing the Liberals in party preference, findings on this question always favoured the government and "the right track" was thus seen to resonate with Ontario voters. Support for the "right track" dipped substantially only during the Bill 160 struggle and a further teachers' strike in fall 1998 (Ipsos-Reid surveys, 1996-99).
} 
practice played a vital, defining role in legitimating the neo-liberal project. This will be summarized later in this chapter.

\section{Resistance and Counter-Hegemony}

Resistance to the neo-liberal government in Ontario, and to neo-liberal governments that follow social democratic governments to power, has been strong and persistent, especially when in transition between paradigms. Under Ontario's ambitious and fast-paced restructuring agenda, many groups across Ontario society have found themselves 'restructured' out of employment, housing, social services and the rights of citizenship. Resistance in Ontario has been broad-based and, at times, intense, but it has not stopped the government from proceeding with its agenda. As we have seen in the case studies, the government faced significant opposition in its first two and one-half years in power, opposition that, under the brokerage politics of previous administrations, either would not have taken place or would likely have resulted in major concessions. ${ }^{4}$

Resistance has been hampered by the tendency for challenger groups to work separately. This served to point out the strength of the government's 'divide and conquer' strategies, which created self-standing pockets of resistance in response, rather than a coordinated, cross-sectoral and inclusive coalition of interests. The contested environment in the transitional phase of the government

4 One is reminded of the federal government's response to student protests in the late 1960 s and early 70s; it developed projects to deflect protest by increasing student jobs under programs such as Opportunities for Youth and Local Initiatives Programs. At the same time, it removed the autonomy that it had granted the Company of Young Canadians in 1969, which led to the group's disbanding and replacement by Katimavik, another youth-led program (Historica, 2003:1), which had less focus on empowerment of the disadvantaged through community development and, presumably, also minimized opportunities for fomenting protest. 
had the potential to evolve into a historic bloc (Ralph, 1997:179)-the ongoing Days of Action against a background of the struggle of public sector workers, Toronto residents, and teachers and parents in the three case-but instead became an internal struggle between different strategies for action. Much of the resistance was centred on defending lost entitlements and was carried out in "middle-class action space" (Boudreau, 2000:45), with its own quality of life issue-set. In its efforts to minimize opposition, even these expressions of freedom of speech and assembly were often countered by government-requested court injunctions or other means of dissuasion, as has been shown in the case studies.

Much of Ontario's formal and organized resistance, and indeed the broader resistance to neo-liberalism (Parkland, 2000:11-12), was conducted in the name of democracy as a response to neo-liberalism's "politics of exclusion" (Sears, 1999:101) that has created a democratic deficit (Kelsey, 1995). Democracy thus became a site of struggle in a war of position within civil society (Hall, 1988:124). The struggle was centred on re-democratizing and reclaiming public space from the state and its experts, who are used as the surrogate voice of the public and have replaced public judgement with public information (Yankelovitch, 1991:8). The struggle for democratization is thus also repoliticizing democracy by conceptualizing it as a goal, rather than a fact (Bruck, 1992:140).

In practical terms in Ontario, challenger democratization discourse had more limited appeal and demonstrated both class and locational (such as urban/suburban and Toronto/rest of province) splits (Isin, 1998:182-4), with the democracy movement failing to make its issues relevant beyond a narrow circle of Ontarians 
mostly living in Toronto. Where common ground and higher consciousness could have been stimulated, for instance, in cities or regions where resistance on other issues already existed, the ongoing "blitzkrieg" of government actions made it difficult to organize beyond one's own defensive ground. Ralph (1977:178) asserts that resistance had three serious limitations: it was reactive against policies already implemented rather than actively promoting an alternative agenda; it was directed personally at the Premier instead of against corporate power; and it did not have a strategy to win power.

The Ontario government's response to this single-sector and sequential resistance has generally been to prevent it (as many groups affected by its policies do not have the resources to protest); marginalize it (by categorizing all protest as radical); convince it (through costly taxpayer-funded advertising); or ignore it (as it did strategically in the case of the Days of Action). Government discursive strategies reinforced the message that the out-of-control, interest-group-led welfare state needed to be disciplined —and that the private sector could do it better. Resistance served to allow Premier Harris to demonstrate "his courageous resolve in the face of rabid 'special interest groups"' to supporters and the media, and was a lesson to challengers and would-be challengers in his '“common sense' morality play"' (Ralph, 1999:179). The government's reaction to resistance also reinforced that not only was there no alternative to the new ways, but there was no going back.

In Ontario, the government was aided in its politics of exclusion by a media seemingly caught off-guard, as was the public and official partisan opposition, by the intensity of its neo-liberal agenda and tactics. As the case studies show, the 
usual primary definition and institutional accommodation awarded by the media to authoritative sources was often strengthened due to the media's lack of preparedness and resources, making them more complicit in the government's agenda than otherwise might have occurred. The media analysis demonstrated that media were often slow to pick up on issues that were significant to the public and were quick to drop them in accordance with the swift ebb and flow-the accelerated phase structures (Fishman, 1980)—of the government's legislative onslaughts.

Media content tended to use routine themes and representations, for instance of strikers or parents, which gave advantage to challengers only in the case of teachers, for whom public credibility was high (Wright, 2003:164). In depicting resistance to the government's initiatives, media differentially appeared to take their lead from the government. The Toronto Sun's coverage of the disruption caused by the public sector strike was in keeping with government messages of disruption and its actions to reduce the impact of the strike. Coverage of the anti-amalgamation struggle showed that in times of uncertainty, the media resort to coverage that is consistent with their ideological and political reputations, with the Sun following a traditional 'action-reaction' pattern, the Globe and Mail maintaining its coverage of authoritative sources and the Toronto Star giving precedence to the challengers. In the Bill 160 struggle, all three of the newspapers examined reported government positions proportionally more often throughout all phases, despite newsworthy (and challenger-led) events that might have suggested a different approach. In retrospect, this latter struggle may have demonstrated a cumulative impact on the government's legitimacy—the government took steps to reassess its communications efforts after 
it—but the media, other than routine reporting, had returned to (and even publicly advocated a return to) normalcy (Toronto Star, 1997:A36).

Communications strategies that supported challenger groups in the alternative meaning domain (Williams, 1977) recognized the importance of gaining media access and even the more informally organized groups had at least a basic knowledge of media practices (Kidder, 2003). A lack of resources hampered the capacity to organize and create linkages with other groups, either like-minded or cross-sectoral, leaving groups to flounder at Gramsci's (1971:180) economiccorporate level of solidarity. They were similarly hampered by traditional strategies that relied on "foot soldiers" (Rykert, 2003) — "an old style of politics for newly emerging realities" (Isin, 1998:186)—-long after such organization has been abandoned in favour of technologically advanced strategies undertaken by those, such as the government or major political parties, with much larger resources (Ginsberg, 1986:160). Challenges coming from an oppositional meaning system were virtually excluded from media accounts; the extent to which such groups tried to gain access or otherwise promote their positions would be a subject of another research project.

Whatever the successes and failures of government and resistance to it, it is clear that the relationship between state and citizens was undergoing a transformation - streamlined and rationalized into an economic relationship that marginalizes the unworthy (Herman \& Chomsky, 1988) and reduces public action space. The unworthy, the disorderly, the have-nots-all form the marginalized nation of Jessop's "two nations" conception of neo-liberalism (1988). Thus, the 
revitalization of the public sphere, which begins the process of reintegration of the economic sphere with the social sphere, would be a fundamental aspect of any alternative strategy to neo-liberalism.

Hall (1988) was one of many analysts who critique neo-liberalism and agree with its adherents that there is no going back to the pre-neo-liberal political landscape. The New Right was successful at demonizing social democracy and the Left for the crisis in the polity (Panitch \& Miliband, 1992:19) and this has hampered efforts at creating alternative strategies (Jessop, 1988:10) that might be expected to be "egalitarian, democratic and... sustainable" (Albo, 1995:107). Practically, as with any regime, the post-war compromise relied on "social capital" that needs to be "renewed and reproduced or it will wither away" (Bourdieu, 1998:5), and 20 years or more of neo-liberalism in different jurisdictions has prevented or curtailed this legitimation. Canada's brokerage politics, in which similar parties attempt to appeal to different constituencies of voters in order to create informal electoral factions, has also lost ground, showing itself to be "ill-equipped to deal with the dramatic intensification of economic difficulties and constitutional controversy of the last two decades [1970s-80s]" (Clarke et al, 1996:21, 124), not to mention that it has been virtually superceded by the ideological and polarized politics of neo-liberalism. In any event, as Kelsey (1994) points out,

[t]hose who nostalgically reminisced about traditional corporatism or promoted pluralist consensus ignored the historically elitist nature of corporatism as an accommodation between different sections of capital and institutionalized labour. It was never a liberating and empowering force for the mass of the population (191). 
Although "recovery of lost ground" (Hall, 1988:11) may not by itself be a politically wise strategic goal, it should be borne in mind that as neo-liberal governments have solidified electorally, they have not been successful in moving citizens away from core social democratic values (Crewe, 1988, 1989; Curran, 1990). In Ontario, social policy issues such as health and education hold continued sway (Ipsos-Reid, 1996-99), even though these issues and the democratic values they imply remain passive and have not supplanted economic issues during election periods. ${ }^{5}$ This suggests, as Jackson (2001:51) maintains, that Keynesianism retains salience in some industrialized Western countries (like the Netherlands and Denmark) that avoided or minimized neo-liberal strategies. In addition, the lack of value change may be indicative of an incomplete, transitional or unrealized hegemony, rather than a durable one. Any alternative strategy to neo-liberalism that does not realize and utilize this would be ignoring an important tool for successful counter-hegemony.

But, given the passage of time, the ongoing globalization of nation-states and the loss of opportunities for ongoing legitimation, most critics of neo-liberalism take the position, as Hall (1988) did after nine years under Thatcherism, that "[ $t]$ he only way of genuinely contesting a hegemonic form of politics is to develop a counter-hegemonic strategy" (Hall, 1988:11). In this, Williams (1983) believed that the central problem of counter-hegemony was "to create an authentic rather than an

5 Tracking surveys show that the Liberal and NDP in Ontario are consistently believable on education, health, the environment and "compassionate programs", while the Conservatives hold dramatic leads on all economic issues and crime and less pronounced leads on honest government and keeping promises (Ipsos-Reid, 1995a; 1997a; 1999). Jakubowicz (1999:47) hypothesizes that education and health are "merit goods" that people take less care to obtain. In a political environment in which government expenditure needs to be rationalized, this complacency can make it difficult to maintain such programs. 
inherited sense of what a society is and should be' (17). Williams, like Hall (1988), stresses that the "commitment to the construction of a new political will must be grounded, if it is to be concrete and strategic, in the analysis of the present' (11). Ernst (1992) as well brings the formation of an alternative strategy to neo-liberalism into the present by stressing the necessity to "confront the economic logic of globalization and the disintegration of national economic policies' (135).

Organizing a counter-hegemony is thus not a project of reversal. It is already a more complex society than the one vacated by Keynesianism (Adamson, 1980) and neo-liberal restructuring has established many more sites of power to be converted or overcome (Isin, 1998:187). Gamble (1993:204) also raises the question of how a counter-hegemony would achieve consent when the corporatist structure has been pulled apart.

Gamble's question gets to the essence of the task of counter-hegemony in a neo-liberal environment. As has been argued in this thesis, Gramsci advocates ideological supremacy as a pre-condition for hegemony. There is nothing to suppose that counter-hegemony would or could be achieved differently. If a hegemony is organic, active and a form of praxis (Ransome, 1992:132-3), then counter-hegemony must comprise the same attributes. The winning of hegemony involves constructing a strategy and developing organic individuals. The development of cultural hegemony, that is, the creation of an intellectual climate for a counter-hegemony to Keynesianism, was an integral factor in the success of the neo-liberal paradigm. From Great Britain's Institute for Strategic Studies and the US's Heritage Foundation to Canada's Business Council on National issues, the 
New Right understood the importance of embedding ideas, of having "policy intellectuals coalesce behind a new theory and reinforce it" (Bradford, 1999:50). George (1997:48) says "the victory of neo-liberalism is... now widely reflected in the media, politics, and the programs of international organizations", but that it took "50 years of intellectual work... of intellectual tenacity and political planning" to overturn the post-war compromise. Bertram (1993:30-1) has pointed out that, just as a new consensus developed around neo-liberalism, so a new generation of economists will have opportunities to influence the ideological construction of the policy experiments that are implemented politically and achieve intellectual ascendancy. Jesson (1988:117) agrees that opposition to neo-liberalism "must shake this intellectual dominance", but adds that it must also develop at a political level of action. Carroll and Coburn (2003:94) theorize that social movement activists have an understanding of power through "a political economy justice frame; that is, they understand domination and injustice... as structural, systemic and materially grounded." This suggests that "in the practices of 'cross-movement networking' and in the political sensibilities of activists, one could discern a potential counter-hegemonic historic bloc that might be constructed around a shared vision and an activist network spanning across movements" (93-94).

The question of on what site the counter-hegemonic struggle is to take place is not unproblematic. The general public does not have much faith in politicians or the political process (Wright, 2003:164) and voter turnout across Canada has diminished steadily with each federal election (Taras, 2001:39). Politics is "no longer an offshoot of organic communities" (Jesson, 1988:117), but a game between 
government and opposition, with the public left out of the equation (Mulgan, 1994:17, 20). The public's point of reference for politics is the media, whose "adversarial approach has fed public cynicism, and alienation" (Underwood, 1998:185). Canadian citizens, says Taras (2001:222) have been "betrayed by institutions and forces at every level of the media food chain" and everything is put ahead of the public interest, in effect, "giving consumers what they want rather than giving citizens what they need." Neo-liberalism has added its own stamp of authoritarian rule to the public's perceptions of government by acting as an "elective dictatorship" (Mulgan, 1992:530), in which governments do not listen to all interests in society, but a select few. The cumulative effect of neo-liberalism in power, after years of struggle to make voices heard, is "a cynical electorate, leading to citizen alienation or anger, and most likely both" (Bradford, 1999:53). Thus, the development of any counter-hegemony would take place under conditions in which the "formal political process loses support and legitimacy while informal political forms of civil society continue to spring up" (Keil, 1998:160) and in which there exists a continuing tension between democratic ideals and the performance of democratic institutions (Norris, 1999:271).

There are other reasons why the formal political process is problematic space for counter-hegemony. As Harder (1996:59) writes, "if the state is not the site for claims for democracy, equality and justice, it doesn't need to address these questions." Speaking from the perspective of the some of the sectors of Ontario society marginalized under neo-liberal policies, Clarke (1992) echoes Harder's lack of faith in the political process and its ability to represent all citizens: "It is hard to 
imagine any meaningful discussion of social issues that fails to recognize the implications of one tenth of the population of the province being at the mercy of a system of punitive, sub-poverty government handouts" (213). Panitch and Miliband (1992:20) have pointed out that social democracy-a logical site for the development of an alternative-was unable to stop neo-liberalism and, in fact, merely "seeks to distinguish itself today primarily by having a better recipe for competitiveness", rather than dealing with the issue of control of capital. Quoting Magnussen and Walker, Carroll and Coburn (2003:89) express concern about a tendency in state analysis to "reduce politics to what revolves around the state, a tendency that thereby traps social critique within the political space established by bourgeois society." In any event, many believed the "inability of the brokerage party system to rise to the occasion and to proffer clearly delineated alternative projects for the future may have finally closed the federal party system as a space for innovation" (Jenson, 1993:160).

Others remain hopeful that the impact of neo-liberalism has prompted a commitment to constitutional and electoral reform (Mulgan, 1992:530; Norris 1999:270), yet prominent issues in formal politics that were delineated in early responses to neo-liberalism still remain today: democratization of well established parties, initiatives to provide democratic control of new parties and the relationship between parties and pressure groups (Held, 1986:9). Proportional representation was an electoral reform adopted by New Zealand after its experience with neoliberalism (Kelsey, 1994:190) and there is ongoing consideration of it in Canada 
(Bleyer, 1992:113; Finn, 2002/03:4). ${ }^{6}$ For those seeking change within the formal political system, Mulgan's (1994:32-33) characterization of the electoral politicians of the future as "entrepreneurial, less class-based, ethical and pragmatic" presents a mixed if not unreassuring image.

Many have chosen instead to advocate for change outside the formal political process and within social movements. As discussed in chapter 3, social movements have not disappeared over time since 1968, but have adapted and professionalized (Tarrow, 1998:207). New or renewed struggles related to globalization, peace and the environment are active nationally and internationally. Broadening action-space beyond formal politics and redefining the political echo Gramsci's concept of politics as "any activities which are intended to change the nature of the spontaneous consent which has been built up in civil society" (Simon, 1982:89), and many movement-based organizations look expressly to Gramsci's work for its emphasis on the unification of interests (Bleyer, 1997:103; Munro, 1997:127; Ratner, 1997:239). This includes diverse interests such as those who operate within alternative and oppositional meaning systems, although, as this thesis has argued, neo-liberal governments such as Ontario's have blurred the distinction between the two. (Interestingly, and in stark contrast, current anti-globalization actions recognize the coalition value of inclusiveness by accommodating the varied tactics and views of participants and designating levels and zones of protest action as red, yellow or green.)

\footnotetext{
${ }^{6}$ Canada remains one of only three Western countries without proportional representation. As an example of the inequities of a first-past-the-post electoral system, a study of the provincial BC election of May 2001 shows that the Liberals won $57 \%$ of the popular vote, but took $96 \%$ of the seats (Brearton, 2003:6).
} 
In Ontario, anti-government resistance with a potential for coalition politics was a reaction to the debasement of community-oriented organization through funding cuts (Kérisit \& St-Armand, 1997), the marginalization of the "disorderly" through discursive strategies and policy change (Hermer \& Mosher, 2002) and the centralized decision making of the neo-liberal government. Early resistance, such as the Megacity issue, attempted to revitalize democratic discourse using the formal parliamentary political process. The organized and resourced resistance from the labour movement and social justice groups in the form of the Days of Action contested the new paradigm both on the alternative terrain of formal politics and on the oppositional ground of "extra-institutional" informal politics (Ratner, 1997:240), a duality which weakened the movement as it was not attached to a definitive and consensual vision of the future (Munro, 1997; Turk, 1997; Conway, 2000).

The failure of the Days of Action shows resistance did not demonstrate political and intellectual leadership, that is, it did not succeed in organizing and leading its allies and it did not establish an ideological base. Importantly, resistance never reached the point where it had "achieved the commanding position on a broad strategic front" (Hall, 1977:128) or became a historic bloc (which does not need to hold state power in order to exercise it (Robinson, 1996a:28). Its failure as a progressive strategy brought into question the very ability to attain Gramsci's unification of interests, as well as the question of the role of labour in a social movement, or, depending on one's perspective, the role of social movements in a labour movement (Levitas, 1986:19). An attitude of mutual suspicion did not begin or end with the Days of Action. Early in the life of neo-liberalism, Levitas's call for 
a new vision "rooted in democratic practices and in the struggles in which people are actually engaged" (19) did not necessarily include labour. Disillusionment on the British Left with the working class as carriers of a new vision has prevented an endorsement of labour as the site on which other social forces and alliances should be absorbed, but there was caution on the extent to which social movements could be relied. The more radical Left, such as Miliband (1985), called for a radical transformation of society that saw labour at the core of "a vast mobilization of many forces drawn from many sources" (24).

In Ontario, there are signs that labour is taking up the challenge of building a broad-based hegemonic movement. In a 2002 strategy document, one prominent and activist union, the Canadian Auto Workers (CAW), which has a strong membership base in Ontario, has recommended continuing with advocacy in electoral politics, but also expanding its work with progressive coalitions $(16,18)$. But the CAW's perspective is in stark contrast-although perhaps in reaction-to a labour-commissioned survey of union members across Canada, which rated "supporting progressive social causes and public policies for working people" the lowest of 10 priorities for their unions (Ipsos-Reid, 1995b:5). ${ }^{7}$ Moreover, given the very low credibility rating that Canadians give unions (Ipsos-Reid, 2003:164), ${ }^{8}$ CAW's strategy of combining education with action will be an uphill battle, both internally and outside the union. Carroll and Coburn's (2003) ongoing project on social movements and counter-hegemonic politics, however, has demonstrated "a

\footnotetext{
7 OPSEU participated in the survey. Presumably, a CAW-only survey would have had different results, given that union's record of progressive action, notably in the Days of Action. Note the date of the survey, which preceded neo-liberalism in Ontario.

8 Unions ranked $10^{\text {th }}$ on a list of 13 professions.
} 
labour movement increasingly open to various popular struggles, sensitive to the needs of diverse and marginalized constituencies, and capable of grasping the connections between movement activism and everyday life" (93).

Similarly, social movements which usually operate extra-institutionally and without resources, have a near impossible task. Counter-posed against the power of the state and all its regulatory and other structuring and shaping faculties (Ratner, 1997:240), they advocate without a well-articulated vision of a counter-hegemonic project (Adkin, 1997:148, Jenson, 1993:161), and are hampered by their own internal divisions about the use of the electoral process (Boudreau, 2000:68-9). In addition, the social movement-labour movement dynamic has not developed to a level of mutual understanding and solidarity in the relation of political forces (Gramsci, 1971:180) that is critical to mobilizing consensus. Yet, social movements and the coalition-based relations they imply are still seen to hold transformative potential as

agencies of social change. Once groups attain a coalescence transcending single-issue and sectoral concerns the action of this fortified movement/party dynamic makes possible a transformative political project permitting the development of alternative programs or paradigms (Ratner, 1992:238).

To many (Bleyer, 1997:109; Cameron, 1991:443; Clark, 1992:223: Ratner, 1997:239; Wallerstein, 1992:109), such transformation relies on a coordinated opposition, working in solidarity on all fronts at once and linked to global struggles (Wallerstein, 1990:48-53).

Given this, using the formal political process as a site on which to develop counter-hegemony represents a decision to wage a war of position with what might 
be considered a limited reformist objective. Hall (1988:149) attempts to rehabilitate reformism by releasing it from its "reformism/revolution binarism" and reconceptualizing it from a Gramscian perspective, contending that it has no "necessary, permanent, inevitable and essential content", but can only be defined "in the conjuncture, in the balance of forces" (Hall, 1988:149). If this is accepted, it thus becomes less important where the counter-hegemonic struggle takes place-or to insist that it take place on a single field of action, which seems contrary to Gramscianism - as it is to achieve "unison of economic and political aims... [and] intellectual and moral unity" (Gramsci, 1971:180) on the elements of a post-neoliberal hegemony. Golding (1992:xii) argues that Gramsci's concepts in essence articulate the basis for a post-liberal democracy grounded in a "'radical' openness, diversity, and contingently formed consent" which in turn establishes a "kind of 'social ethics' that Gramsci quite simply calls 'progressive'." The state in itself is neither outsider nor foe (Ratner, 1997:238) and "although a major locus of power, it is not the only locus of power" (Wallerstein, 1990:47). As Wallerstein reminds us, "everything else"-control of economic resources, intellectual definition and nonstate institutions- "may be the key to controlling the state apparatus" (47), rather than the other way around. This being said, the state's hegemony will, in the end, have to be controlled if a counter-hegemony is to be achieved, both politically and culturally (Mattelart, 1983:39), even as globalization and the changing social, political and economic relations it brings creates an "enemy [that] is much more amorphous" (Jakubowicz, 1993:47). Beck (2001) would argue that we are already operating within a post-neo-liberal environment, one in which faith in neo- 
liberalism and the power of the market has been undermined and superseded by the need for state security in the wake of the events of September 11,2001. This, and the consequences of the "vulnerabilities that follow directly from a global political economy rooted in networks of communication and transportation" (Mosco, 2003:36), are a reminder that the diffusion of power sites under neo-liberalism (Isin, 1998:187) and its concomitant "multiplication of global communications and transportation links also multiplies the number of nodes from which to attack and the number of nodes that are open to attack" (Mosco, 2003:36). Under these political and communicative conditions, counter-hegemony is a daunting Gramscian task.

Even if counter-hegemony fails—and 'failure' is a problematic term-a system disrupted by social movement activity "does not simply return, pendulumlike, to point zero and go on as if nothing has happened" (Gitlin, 1980:291), but leaves behind "stratified deposits" (Gramsci, 1971:374) or a cultural and social residue in the dominant culture (Williams, 1977:122).

\section{Legitimation, Consent and Communicative Democracy}

This thesis has examined the state's need for legitimacy, both theoretically and through the example of Ontario, in constructing and maintaining hegemony. It has been argued that the media are a key element in ideological reproduction (Bruck, 1992:140) and are themselves "crucial fields for the diffusion of social meaning" (Gitlin, 1980:292) in which "competing discourses struggle for legitimation (Hansen \& Murdock, 1985:255). At stake is the ability to "define the limits of public 
debate" (Raboy, 1983:130). This ideological struggle is exacerbated by the shifting dynamics and trends of media systems and practices which have reproduced and reinforced unequal power relations in the interest of capital, as represented here by governments under the influence of a new paradigm of governance, neo-liberalism.

Keane (1991:114) has contended that neo-liberalism is anathema to democratic communication as it is market-driven and therefore cannot deliver on freedom of choice, open expression and representation of diversity of opinion. When UNESCO's MacBride Commission called for democratization of communications in 1980, it envisaged a free exchange of opinion that was societywide, which as Jakubowicz (1993:41) has interpreted, "presupposes the existence of not only democratic media, but also of democratic arrangements in general." As we have seen in the exemplar of Ontario in this thesis, a full range of opinions freely expressed along with media acting autonomously within a strong public sphere remains an unnecessary, if not a dangerously delegitimating prospect, to the government, yet it is an unfulfilled but "fundamental condition of democracy" (Splichal, 1993:14) to its challengers.

Advocating from the margins of society, social groups and movements-the silenced voices of neo-liberalism's politics of exclusion—play a leading role in pursuing democratic values within the state and, most recently, in the global environment as well. The challenge to the state lies implicitly in their rejection of a passive public that is grounded in relations of consumption — the "competitive, elitist model of democracy" (Hackett \& Zhao, 1998:226) or "thin democracy" (Atkinson, 1994a:17)-in favour of a public that is composed of active participants 
situated within the relations of production (Splichal, 1993:12) or "deep democracy" (Atkinson, 1994a:17). The reconstituted public sphere can thus be organically reconstructed for "ordinary citizens in the microworlds of everyday life" (Hackett \& Zhao, 1998:226) and "grounded and connected in the experience of ordinary people" (Hall et al, 1978:372), rather than formulated by coercive, legitimative processes from above. It can also address Blumler and Gurevitch's (1995) concern for what they have called a "crisis of communication for citizenship", which was related to the neo-liberal response to the constructed crisis in the polity. "Without a public sphere, democracy and civil society", as Beck (2001) has written, "there can be no legitimacy."

Jakubowiz (1993:47-9) advocates for a "communicative democracy" from the starting point that the essence of the concept lies in democracy, whatever the subject of discussion. Communicative democracy thus implies both structural change and active agency and is broader than media democratization in the same way that hegemonic communication, unlike political communication, encompasses both base and superstructure. The practical link between social movements and communicative democracy is in the recognition that "more and more of the affairs of public life are played out in media content" $(50)$ and the understanding by these groups that media content is not the end in itself but is part of a system that is structured to marginalize or exclude their perspective. A campaign for communicative democracy as a goal, logically, then becomes counter-hegemonic in purpose. 
Hackett (2000) also has taken up the challenge of communicative democracy, strengthening the link between it and social groups by conceptualizing it as a social movement and a priority for progressive politics. He contends that a "progressive project of redistributing wealth and power within (or against) global capitalism will necessarily have to confront and challenge the corporate media system" (61), due to that system's economic linkages with and ideological legitimation of global capitalism. Media and communication economics can in fact be considered "the most dynamic features of the globalizing market economy" (Herman \& McChesney, 1997:38), so “[a]ny challenge to the structures and ideology of contemporary capitalism ... [is] a challenge to the dominant media" (Hackett, 2000:63).

Hackett's research shows a common commitment by "progressives" to key elements of media democratization, which "comprises efforts to change media messages, practices, institutions and contexts (including state communication policies), in a direction which enhances democratic values and subjectivity, as well as equal participation in societal decision-making" (64). Although it is sometimes unclear whether Hackett's project seeks space for alternative/oppositional media/communication or is an agenda of democratic communication, and also how his democratization is distinguishable from a pluralist conception of democracy, which he has mentioned elsewhere (Hackett \& Zhao, 1998:229), his project is inclusive of both alternative and oppositional approaches, seeing "potential synergies" (81) among them and open to a Gramscian relation of political forces. His conceptualization of communicative democracy as a social movement is novel 
and compelling in its situating of media and communication at the forefront of an agenda for a broad progressive politics (82).

Hackett's project, and any other that seeks to democratize communication, must contend with entrenched media systems and practice that have been strengthened and extended by commercialization and internationalization. It must clarify the role of public media that are government-led but underfunded and are slipping into commercial practices (Keane, 1991:124, 150); it must find an alternative to the market-led system, where no viable alternatives are said to exist (Herman \& McChesney, 1998:196); it must reintegrate social needs and social responsibility into media practice (CPBF, 2003:1).

Picard (1998:215) suggests that media system transformation needs a national, provincial and international vision that must be pursued simultaneously. Hackett et al (1996:263-4) also look to effective public policy to limit and prevent mergers and takeovers that are the "product of rational, profit-maximizing business decisions" and that at the same time block democratic communication, "to the extent that they limit the quality of information, the diversity of viewpoints, and the equality of access available in the media system." Policies could include anti-trust legislation, reduction of barriers to new actors and promotion of non-commercial content (Picard, 1998:214-5). The Campaign for Press and Broadcasting Freedom (2003:2) is more specific in its policy restrictions on ownership concentration. It calls for legislation with three goals: "to limit and eventually reverse the current level of media ownership concentration;... to provide measures that will promote a diversity of media ownership; and... to encourage the media to more effectively live 
up to their social responsibility and provide a wider range of coverage and content." Decentralization of media into regional and local nodes of operation, coupled with a legislative imperative to reflect communities, can ensure that media practice is grounded in local needs. As the failure of the poll tax in the UK showed, a decentralized media system can help resist a heavily promoted government campaign (Golding, 1992:520). Limiting the power of ownership also curtails legitimating power of the dominant system and undermines its consent (Cameron, 1991:443).

The effects of commercialization, which erodes the public sphere into an "audience sphere" (Mosco, 1982:111) that treats citizens as consumers, can likewise be limited through legislation and regulation and by the development of noncommercial alternatives, such as publicly owned media, that redress the lack of diversity and homogenization of content in commercial media enterprises. These kinds of policy remedies de-privilege private consumption and re-privilege public discourse (Hackett et al, 1996:266) and, in so doing, emphasize active production processes over passive relations of consumption. Active production processes include the participation of labour and other marginalized groups (Knight, 1998:118).

A significant aspect of communicative democracy is creating a new imaginary for developing alternatives to the status quo. One optimistic strategy to stimulate alternatives is to take the resources-technology, expertise, labour-that are already structured into current media systems and use them "to participate in the process of their own re-creation" (Mosco, 1982:168). It is optimistic of course 
because "existing powers will not readily condone such uses (168)", but its effectiveness as a strategy is to shift democratizing consciousness into the "process of becoming" (S. Golding, 1992:128 ${ }^{9}$ ) that is critical to building Gramscian counterhegemony.

There are two aspects to 'alternatives' in the interest of communicative democracy: developing alternative media and using alternative practices, both of which can be taken to understand that they are inclusive or respectful of oppositional representation and practice. The first, creating cooperative and democratic alternative media, is important to building popular democratic movements and serves a hegemonic legitimating function that does not rely on dominant media systems (Hackett et al, 1996:271). But ownership of the means of production is difficult to finance (it is a reasonable assumption that entrepreneurs in the popular sector, let alone any willing to take such a large financial risk, are hard to find) and maintain (no doubt in a hostile environment for advertisers) or else surely it would have happened before now. The resurrection of $M s$. magazine as an advertising-free product was only achieved after 15 years of traditional publishing that was rife with conflict and contradiction between the magazine's content and its ads. ${ }^{10}$ Canadian alternative magazines such as Canadian Dimension and Our Times launch regular appeals for funds from their subscribers in order to keep publishing. In addition, in a choice between "spending scarce resources on a goal that seems too difficult, too broad, or too indirectly related to their primary interests" or

\footnotetext{
9 All references to "Golding" in this thesis refer to Peter Golding. In this chapter, "S. Golding" appears twice and refers to Susan R. Golding.

10 See the ongoing debate over the years in that magazine, as well as Steinem (1995).
} 
"scrambling for access in the existing media system" (Hackett \& Zhao, 1998:215), many groups will choose the latter.

Yet there exist considerable success stories in creating alternative or oppositional media, Canadian Dimension and Our Times among them. Hackett and Zhao (1998:95) give the example of Vancouver Co-op Radio, one of only two community-access radio stations in Canada, "member-owned, volunteer-operated and non-commercial" since 1975. Its mandate is to provide access and programming to social movements that are underrepresented in the commercial media. McChesney and Nichols (2002:122-3) point to the Independent Media Centers that first emerged in the 1999 protest in Seattle against the World Trade Organization. The centres are a decentralized network that provides alternative news accounts and commentary on emerging issues and events, such as anticorporate protests, political conventions and world conflicts. Others have provided details of alternative media enterprises throughout Canada, the United States and globally (Mosco, 1996:240-1; Herman \& McChesney, 1997:199-204; Hackett \& Zhao, 1998:213-222; McChesney \& Nichols, 2002:38-40). The diversity and the sustained period of time over which these alternative media have acted, without resources and likely under challenge, are testimony to the possibilities for "small independent media [that] act as cultural vehicles circulating critical interpretations of reality" (Raboy, 1984:130). Practically, without alternative media, challenger groups have no option but to seek access to mainstream media to publicize their positions and thus risk dominant interpretations of their efforts, which can easily mean "losing voice" (Barsamian, 2003:4). This is one reason why activist Charlotte 
Ryan, author of Prime Time Activism (1991), advocates that these groups both use the mainstream media and develop their own media. Their hope may rest in Laxer's (1996) perhaps utopian claim that "[o]nce a social movement reaches a certain size, it is much less dependent on the media than is a political party. Indeed, such movements can flourish even where newspapers and electronic media distort the truth about them, because they are capable of establishing a more direct and personal network of communication than that of the media" (A15).

Second, alternative or oppositional tactics can either be used to gain access or replace access to media. Such tactics include the "disruptive access" (Molotch \& Lester, 1973) of demonstrations, which can be marginalized by the media as "interesting" news (appealing to individual members of the human race), but not "important" news (concerned with institutions and decision-making) (Golding \& Elliott, 1979)—but still have a media presence. "Jamming" and "hoaxing" (Hackett \& Zhao, 1996:215-6) are also media relations tactics used by alternative and oppositional groups, such as shutting down corporate fax and e-mail systems by sending mass communications, spoofing advertisements (as in Adbusters magazine) or sending fake news releases to the media. Tactics can also include bypassing the media altogether when challengers become "anti-sources" by disseminating their own direct actions and bypassing the traditional media (CBC, 2000). Although inadequate for changing media systems, these tactics expand the range of voices, experiences and perspectives normally found in the dominant media.

A democratizing movement has also developed from within the media that can be considered an alternative (as opposed to oppositional) media practice. Public 
or civic journalism is an American-led phenomenon, now spread to Canadian media practice, which actively facilitates public discussion and helps in bringing the public to judgement. Rosen (1996:102) says public journalists see themselves "as conveyors of public talk, aids to a more active citizenry, modelers of deliberative dialogue, supporters of a healthy public life." The reaction to public journalism is mixed. Although it provides a needed link to communicative democracy and journalists have a legitimate interest in protecting democracy, public journalism has also been dismissed as stopping short of a model in which "authority is vested not in the market, not in a party, and not in the journalist, but in the public. Nothing in public journalism removes power from the journalists or the corporations they work for" (Schudson, 1998:138). Journalists need to go beyond public journalism and advocate for systemic change, according to Bruck (1992), although it should be acknowledged that "information retrieval and reporting is not work that necessarily privileges its practitioners with special insights, political courage, or an activist vision" (155).

Media practice has to deal with a significant constraint in the regime of objectivity, which works against democratization; it "obscure[s] the integration of news production with commercial imperatives, to reproduce hegemonic definitions of reality in news narrative, and to dissuade journalists from ideologically challenging corporate control of the media" (Hackett, 2000:69). It is not clear under these conditions if a "better" objectivity is possible, as Hackett and Zhao (1998:231) suggest, or even if it would be desirable in communicative democracy, especially within current constraints of news production. 
Lastly, communicative democracy needs to come to terms with the role of public media or, perhaps more accurately, the nature and the role of the state in public service media. Opinion on this issue is diverse and crosses ideologies. Williams (1968:13), for instance, somewhat surprisingly, believed public ownership had no place in democratic communication, but was unavoidable. He advised a duality of ownership between the state as funder and producers of cultural content. Sparks (1993) criticizes Williams for his ambiguity over the nature and the role of the state in public service media and says it is "unthinkable" (85), that "[a] system of democratic ownership is only possible in a democratic society that has no need of a state machine" (85). O Siochru (1996:6) has written that liberalization has eroded the public good and the state has shown itself unable to protect it, so the alternative media sector must advocate for a redemocratized "public service ethic" and find it an economic base. At the same end of the spectrum of possibilities for public broadcasting, American communications theorists, for whom a CBC or a BBC-like tradition does not exist, often reject the idea of public ownership outright as an option in media democratization (Picard, 1998).

These arguments serve to situate public service media as we know it as a "half-measure", neither independent, competitive and private, nor completely publicly conceived and operated. This suggests that the CBC, which has been the subject of popular sector campaigns for its survival, ${ }^{11}$ as well as a recent mandate review, ${ }^{12}$ stands in the way of a more radical form of public communication. The

11 See Friends of Canadian Broadcasting at www.friendscb.org/

12 See "Making Your Voices Heard." Report of the Mandate Review Committee - CBC, NFB, Telefilm. Department of Federal Heritage. Ottawa, 1996. 
mandate review spoke to the need to reflect "Canadian voices, values and experiences" (1996:1), but drastic and ongoing funding cuts throughout the 1980s and 90s have forced the $\mathrm{CBC}$ to rely on advertising to survive (Vipond 2002:138). ${ }^{13}$ Its ability to meet its mandate is thus limited at the same time as it competes with private-sector media for ad revenue - some say from an advantaged position because of its public financing. It is also vulnerable to policy change by governments inclined to privatization and deregulation (Golding, 1994:9-11). For communicative democracy, the challenge of public service broadcasting-in current terms, what to do with the $\mathrm{CBC}$-lies in stimulating the conditions for its "reembedding in the social life of civil society" (Keane, 1991:153), thus re-legitimating its existence. More broadly, freedom of communication in a democracy relies on parliaments to provide "a vigorous political and constitutional defence (149)." The government-financed channel TVO in Ontario is thus in a difficult situation as a public broadcaster, not having succeeded in meeting its challenge of adequately representing Ontarians (Kozolanka, 2001:63), undefended by the neo-liberal majority in the Ontario legislature and vulnerable to privatization and politicization with its restructured mandate (61).

The social movement for communicative democracy must recognize that, although alternative and oppositional media and practices perform a valuable role in keeping media democratization issues on the public agenda, it can be limiting to a movement to always "remain in the margins" (McChesney \& Nichols, 2002:1233) of the dominant media system, living in "an 'alternative public sphere',... either as a

13 One-fifth of CBC's budget now comes from advertising. See also chapter 3 of this thesis. 
long-run phenomenon, existing on the fringes of the establishment media, or springing up around a specific issue" (Jakubowicz, 1993:43). The strategy for communicative democracy must go beyond narrower 'alternative' practices and tactics and small-scale 'alternative' projects to create an oppositional consciousness that examines and acts on the structural conditions for change. The MacBride Commission implied as much in its commitment to the right to communicate as a fundamental human right (Mosco, 1996:241) and to a balanced flow of information (Hackett, 2000:72). Structural changes could include the public policies implied in the Campaign for Press and Broadcast Freedom's three objectives for media reform (CPBF, 2003); as well as revitalizing a non-commercial public broadcasting system; facilitating non-commercial community radio stations; lowering mailing costs for non-commercial publications; banning political advertising or allowing equal, free time for other candidates; eliminating television advertising for children's programming; and establishing commercial-free time for news broadcasts. ${ }^{14}$ Some of these measures in themselves directly restructure the media; others contribute to a changed environment that leads to structural change. A mix of alternative and oppositional strategies can expand the overall space for resistance, if not counterhegemony:

The presence of oppositional movements can force dominant power structures to bow to opposing viewpoints, while activists who engage with mainstream media can push for practices and policies that offer more opportunities and resources for oppositional cultures to grow and thrive (Stein in Hackett, 2000:81).

14 This list is adapted from McChesney and Nichols (2002), pp. 134-5. 
In other words, as mentioned earlier in this chapter, a coordinated approach operating on many fronts can create synergies and satisfy groups with divergent perspectives by emphasizing the movement's collective strengths "rather than the potential divisiveness of its diversity" (81). Kelsey's (1995:372-6) manual for "counter-technopols", with its specific tactics and approaches based on the New Zealand experience with neo-liberalism, is a valuable tool to constructing such counter-hegemonic space.

Positioning communicative democracy as a social movement may seem to merely formalize the efforts that have been taking place to democratize the media. But it also contextualizes the movement within a "broader (and mutually constitutive) project of social transformation" (Hackett \& Zhao, 1998:236) that includes other social movements and struggles for democratization, both inside and outside the formal political process, in a direct challenge to neo-liberalism's arbitrary and undemocratic nature. These other movements are already operating within Gramsci's relation of political forces and working to "transcend particular social categories by uniting a diverse collection of people around a specific interest or cause" (Mosco, 1996:239). A movement towards communicative democracy would thus become a partner in a coalition for transformation of civil and political society through a war of position.

The struggle for the right to communicate has global repercussions. The successful campaign by Western nations and media against UNESCO and the New World Information and Communication Order in the 1980s, led by the US and Great Britain, is a reminder of the power of transnational neo-liberal interests to shape the 
world order (Herman \& McChesney, 1997:25). A goal of communicative democracy must therefore also be to establish "a global non-profit public sphere to replace, or at least complement, the global commercial media market" (204).

Even the strongest transformative social movements need to play from the strength of a positive intellectual environment. As George (1997:48) has pointed out, "the victory of neo-liberalism is the result of 50 years of intellectual work. Neo-liberal ideas did not enter haphazardly into the everyday lives of people, but were aggressively propagated, financed and renewed $(48,51)$ :

[W]e are not born with our ideas and must somehow acquire them; ... in order to prevail, ideas require material infrastructures... [T] hese infrastructures will largely determine the intellectual superstructures; this is what Gramsci meant by capitalism's 'hegemonic project'. Defining, sustaining, and controlling culture is crucial...

Over this time, the media have been "a primary target" for the Right, which has devoted considerable funding to "promote pro-corporate right-wing media and media 'deregulation' (McChesney \& Nichols, 2002:122). ${ }^{15}$ George urges counterhegemonic forces to rethink strategies that are overdetermined by community projects, however worthy, at the expense of creating the intellectual climate to support them (51). Kelsey (1995:373-4) agrees that counter-hegemonic strategies need to include the development of a coordinated body of research and analysis structured within well-resourced think tanks. Academia can contribute to this environment by fostering critical analysis, educating and supporting critical

\footnotetext{
15 A recent media report profiled the efforts of the American Right to counter-act the "liberal media." The report cites the National Journalism Center, started in the 1970s, the Institute on Political Journalism (sponsored by the Fund for American Studies) and The Leadership Institute as three of at least 10 training programs designed to produce journalists with a 'different' perspective on news gathering (CS Monitor, 2002:11).
} 
scholarship and developing coordinated, cross-departmental research—and, importantly, promoting it. For example, Hansen \& Murdock (1985:255) suggest that "the insights of linguists, structuralists and semioticians can be combined with the more established techniques of content analysis to produce a more detailed and sensitive account of the way that discourses are transformed and worked on as they pass through the news making process." Garnham's (1994) admonitions not to detach communication research from material reality or overspecialize and isolate the field are also useful.

\section{Gramsci, Hegemony and Post-Neo-liberal Transformation}

Given the continued contestation of the government of Ontario's policies, it is possible that the counter-hegemonic impulse which was so clearly demonstrated in the transitional years of the emergent hegemony in Ontario has left sufficient social and cultural residue (Williams, 1977:122) to foster the development of a strong and more democratic public sphere as a necessary condition to challenge the hegemony (Golding, 1990). For those who seek to change (or maintain) the structures within which they live, the ability to "imagine an alternative future for themselves or others-as collective actors-is a crucial precondition for action"(Jensen, 1989:76). It is then possible that a hegemonic bloc can be constructed with sufficient strength to transform the existing hegemony under conditions in which an organized crosssectoral social movement works on multiple sites of power, including the formal political process, and connected to the anti-globalization movement. 
The government of Ontario, which conducted a war of position before coming to power, has maintained hegemony without renewing itself organically or realizing durable consent and finds itself facing a Gramscian crisis in legitimacy, as described in Jessop's (1983:105) estimation of hegemonic projects, as exercising a form of passive revolution, and is therefore vulnerable to such a counter-hegemonic movement. The war of position fought by the Conservatives was not a simple exercise in gaining electoral power with the traditional strategies and tactics of the electoral process. Instead, the Conservatives actively constructed conditions conducive to establishing and legitimating a new hegemony by re-visioning and reorganizing conservatism at the level of grass-roots internally to the party and beyond. It also took advantage of a receptive social, cultural, political and economic environment pre-conditioned by Canadian corporate elites and their ideologically supportive 'think tanks' that actively exerted influence and shaped both the discourse and the structure of the new paradigm of neo-liberalism.

After coming to power in 1995, however, the new Ontario government has not extended its "economic-corporate solidarity" (Gramsci, 1971:180). As a government, the Conservatives have used the powerful resources of legitimation that lie in the hands of government through the bureaucracy that supports it, particularly in the use of public relations, public opinion research and political consultancies, but they are distanced from the organic process of outreach that constructed the Common Sense Revolution platform that led them to power. Instead of renewing their hegemony organically, they use strategic alliances, blitzkriegs, crisis constructions and 'divide and conquer' strategies, among other short-term 
tactics, to prop it up by "hegemony protected by the armour of coercion" (Gramsci, 1971:263), or coercive consent. The Conservatives have thus moved from an active hegemony - based on "the unification of interests, movements and the party philosophy and program"- to a non-hegemonic restructuring strategy-"when entrenched norms constrain decisive state action, and when immediate collective interests conflict with priorities for re-establishing viable accumulation" (Neilson, 1998:51-2). Although they governed as if they had an all-powerful mandate to pursue their project, the Conservatives still seek an active hegemony as a final goal (53).

Many of the specific tactics used by the Ontario government do not have inherently neo-liberal properties. Since 1995, other political parties, both in Ontario and beyond, have learned the value of the coercive consent of tactics that can provide quick non-organic consent at the expense of an informed and active citizenry and public sphere. Ontario Liberals have adopted policies on education and corporate support that are similar to those of the government in an effort to win electoral power (Lindgren, 2003:A4). In the UK, 'the third way' that ended the political polarization between the Conservative and Labour parties stands as a lesson in neo-liberal strategic alliances at the same time as it shows the power of media corporations: Prime Minister Tony Blair met with media magnate Rupert Murdoch "to assure [him] of his moderation and express hopes of friendlier electoral treatment" in Murdoch's newspapers (Herman \& McChesney, 1997:169). Blair then "unilaterally abrogated a Labour Party [electoral] platform demand for an investigation and program for dealing with media concentration" (169). 
Using Gramscian hegemonic theory, the case studies in this thesis were intended to demonstrate how conditions were constructed under which neoliberalism gained political and ideological space; how the Ontario government maintained hegemony despite resistance to it; and how communications systems and practices aided in constructing and maintaining the Ontario neo-liberal project. In so doing, the case studies show how ideological reproduction functions, "constrained rather than controlled or determined" (Bruck, 1992:156) by the legitimating power of hegemony-seeking forces.

The resistance to the emergent Ontario neo-liberal hegemony was forged organically in the development of Gramsci's economic-corporate relation and led by Gramsci's organic intellectuals who have "the capacity to be an organizer of society... to create the conditions most favourable to the expansion of their own class" (1971:5-6). It was also, however, bounded by class and group interests, differential conceptions of activism, lack of challenger cohesion and resources, relations with traditional electoral politics and mutual distrust between organized labour and social movements. In addition, time pressures caused by blitzkriegs prevented the broader organization of dissent into a cohesive movement and the exercise of participatory democracy. The potential of the Days of Action, which attempted to capture the growing discontent with the government and channel it into a convergence of political society with civil society in its own attempt at a war of position, was itself depleted by lack of ideological and political cohesion and was unable to move to the emancipatory third and hegemonic level of Gramsci's balance of forces. The Days of Action, at best, provided an opportunity for a debate on how 
political change happens (Munro, 1997:139) and, at worst, were "a diversion: oneday shows of force that lead nowhere but to despair" (Turk, 1997:176). Resistance was also hurt by conditions beyond the control of citizen activists: the government's restructuring policies and discursive strategies that worked to disempower and disengage citizens from action and the government's ability to forge sufficient consent. In the latter, the media demonstrated how they accommodated the government agenda by consistently producing accounts that allowed the government to frame issues and set agendas. In the face of persistent citizen resistance to the government, the media were often late to recognize the shift in focus and did not create accounts that contextualized resistance, treating each issue and action as selfstanding and thus contributing to diffusing its potential.

It is hoped that these case studies are able to provide understanding of how traditional forms of politics and its politicians, in their role as the primary definers of society, and the media, in their role as secondary definers, have structured preference to set the terms and limits of public debate (Hall et al, 1978) and thereby shape meaning. But such dominance is neither natural nor total nor exclusive (Williams, 1977:113). Interruptions occur in the political process and there are times when ideological closure is not complete, a reminder that primary definition must not only be won, but sustained (Deacon \& Golding, 1994). The case studies show that transitional times-when "the old is dying and the new cannot be reborn" (Gramsci, 1971:276) —in an emergent hegemony are times that are, ideologically, particularly permeable and open to alternative and oppositional challenges. (Mercer (1980:109) has even called Gramsci's work "a theory of transition.") 
By December 1997, halfway through its mandate, the seemingly unstoppable path of the emergent Conservative hegemony faltered as the ongoing challenge to its hegemony began to have an impact on the government's credibility, as demonstrated in the decline in its popularity and the government's reaction in the form of a revised communication strategy. The analysis in this thesis shows that the state reached a decisive moment in the new hegemony, a period of "organic crisis", if not a warning of a growing "crisis of authority" (Gramsci, 1971:210), yet it was able to "reabsorb the control that was slipping from its grasp" (211) by virtue of "the apparatus of state coercive power" (12). It was helped by the failure of the joint social justice-labour coalition heading the Days of Action to move towards its planned province-wide protest; the absence of media coverage and analysis that linked instances of contestation, such as in the case studies here, with a broader social movement framed by the Days of Action; and the inability of single-issue challenger groups to organize across sectors.

The implications of the Ontario state's developing crisis of authority and the failure of the contesting political forces to seize the moment are serious for democracy and communicative democracy. If a communicative democracy movement is to be taken seriously, it must both understand and lend understanding to the importance of "the 'is' and the 'ought' of a democratic possibility" (S. Golding, 1992:xii) in hegemonic struggle. McChesney and Nichols (2002:137) note that media activism surfaces in turbulent times, while Jakubowicz (1993:42) has noted that "once relative stability returns, the situation changes." It is therefore vital 
that the political moment in the transition be recognized as it is happening and not be lost either in the process of becoming or the struggle against it.

Communicative democracy must also come to terms with its place in the broader political system in which it is an active agent. Communication plays and can play a crucial role in economic and social transformation. Referring to Mattelart's critique of Chile's Allende government for not adequately using communications when it came to power, Raboy (1984:124-5) recounts how communications "must reach down into the most submerged levels of society to democratize the communication system and destroy what is fundamentally a relationship of domination." According to Raboy (and Mattelart), participation in communication is "the highest form of popular democracy in a new society" (125). Communicative democracy must therefore continue to be positioned and function as a social movement, inculcated organically, as is hegemony, within "a whole body of practices and expectations, over the whole of being" (Williams, 1977:110). It must also be prepared to question the nature of the system in which it is structured: how can communicative democracy exist within an undemocratic system? Gramsci's hegemony "demands a real democratic relationship within the hegemonic system and... implies a democratization of the institutions through which it is exercised" (Mouffe, 1979:5). The task of transformation should be the same for the communicative democracy movement as it is for democratic social movements: the reinvention and reconstruction of civil society within an intentional, inclusive, emancipatory local and global political hegemonic project. 
The significance of Gramsci's theory of hegemony to this thesis lies in his emphasis on the relationship between the superstructural world of ideas, embodied in the processes of legitimation, and the material world, with its structured interest in capital accumulation and dominance, which together neo-liberal politics has used skillfully. This thesis has aimed to demonstrate through "concrete, historically specific study" (Hall et al, 1977:45) that hegemonic projects are not natural and determined, but socially and politically constructed in dominance in a process that requires consent and therefore implies resistance. Hegemony is thus always in motion and never secure, containing seeds of the next hegemony (Gramsci, 1971:263) in a powerful dialectic that recognizes that every crisis is also a moment of reconstruction; that there is no destruction which is not, also, reconstruction; that historically nothing is dismantled without also attempting to put something new in its place; that every form of power not only excludes but produces something (Hall, 1988:164-5).

Gramsci's conception of civil society as a terrain of political and ideological struggle that leads to social transformation also explicitly rejects economism (1971:407) and emphasizes social agency. His theory of hegemony is a political strategy that illustrates how individuals and groups/classes can work through dominant, alternative and oppositional meaning systems to create a system of alliances to transform relationships within civil society and shift the balance of power:

[W] hen the individual can associate himself (sic) with all the other individuals who want the same changes, and if the changes wanted are rational, the individual can be multiplied an impressive number of times and 
can obtain a change which is far more radical than at first sight ever seemed possible (353).

Thus individuals consciously acting together in ideological struggle can transform the state. For citizens of Ontario, Gramsci offers a way out of political defeatism (Golding, 1992:504) and the hope of movement away from neo-liberal restructuring towards an actively democratic reconstruction of civil society that, in this thesis, requires communicative democracy. 


\section{BIBLIOGRAPHY}

Abelson, Donald E. (1999). "Surveying the Think Tank Landscape in Canada." Public Administration and Policy: Governing in Challenging Times. Ed. Martin W. Westmacott and Hugh P. Mellon. Scarborough, Ont.: Prentice Hall Allyn and Bacon Canada. 91-105.

Abelson, Donald. (2002). Do Think Tanks Matter? Assessing the Impact of Public Policy Institutes. Montreal and Kingston: McGill-Queen's University.

Abercrombie, Nicholas. (1980). Class, Structure and Knowledge: Problems in the Sociology of Knowledge. Oxford: B. Blackwell.

Abercrombie, Nicholas, Stephen Hill and Bryan S. Turner. (1980). The Dominant Ideology Thesis. London: Allen and Unwin.

Abercrombie, Nicholas, Stephen Hill and Bryan S. Turner. (1990). Dominant Ideologies. London: Unwin Hyman.

Abraham, Carolyn. (1997). "Region to pay Full Cost of Buses." Ottawa Citizen. 15 January 1997: A1.

Adam, Mohammed. (2001). “Alberta's Clinical Approach to Reform: Why Ralph Klein performed Surgery." Ottawa Citizen. 31 October 2001 http://www/canada/com/ottawa/story.asp?id + \{EE56F620-26D4-41E8-9D4C001D3Ea26

Adamson, Walter L. (1980). Hegemony and Revolution: A Study of Antonio Gramsci's Political and Cultural Theory. Berkeley, CA: University of California Press.

Adkin, Laurie. (1992). "Counter-Hegemony and Environmental Politics in Canada." Organizing Dissent: Contemporary Social Movements in Theory and Practice. Ed. William K. carroll. Toronto: Garamond. 135-156.

Albo, Gregory. "Debt and Discourse in the World Economy: An Introduction." Studies in Political Economy. 48 (1995):107-111.

Albo, Gregory and Jane Jenson. (1989). "A Contested Concept: The Relative Autonomy of the State." The New Political Economy. Ed. Wallace Clement and Glen Williams. Montreal and Kingston: McGill-Queen's University Press. 180-211.

Aimer, Peter. (1989). "The Changing Party System." New Zealand Politics in Perspective. Ed. Hyman Gold. $2^{\text {nd }}$ ed. Auckland: Longman Paul. 260-274. 
Toronto Star. (1997). “All Teachers should call off Strike.” Editorial. 7 November 1997: A26.

Anderson, James A. (1996). Communication Theory: Epistemological Foundations. New York and London: Guilford Press.

Anderson, Perry. (1977-1977). “The Antinomies of Antonio Gramsci." New Left Review. 100 (November-January): 5-78.

Atkinson, Joe. (1989). “Mass Communication's Economic Liberalization and the New Mediators." Political Science. 41: 85-108.

Atkinson, Joe. (1994a) “Health Reform and 'Thin' Democracy,” Political Science. 46.2: 193214.

Atkinson, Joe. (1994b) "The State, the Media and Thin Democracy." Leap into the Dark: The Changing Role of the State in New Zealand Since 1984. Ed. Andrew Sharp. Auckland: Auckland University Press. 146-177.

Augelli, Enrico and Craig Murphy. (1988). America's Quest for Supremacy and the Third World: A Gramscian Analysis. London: Pinter.

BC Liberals. (2001). "A New Era for BC begins within 90 Days." Election platform document. www.bcliberals.com

Bagdikian, Ben H. (2000). The Media Monopoly. $5^{\text {th }}$ ed. Boston, MA: Beacon Press.

Bailey, Patricia. (2002). "Harris offers his vision of Canada." Ottawa Citizen. 6 December 2002. A7.

Barker, David and Kathleen Knight. (2002). "Political Talk Radio and Public Opinion." Public Opinion Quarterly. 64.2: 149-170.

Barsamian, David. (2003). "An Interview with Charlotte Ryan.” Z-Net. Z Magazine. May 2002, http://www.zmag.org/Zmag/articles/may02barsamaian.htm

Battle, Ken. (1998). No Taxation without Indexation. Ottawa: Caledon Institute of Social Policy,

Baxter, James. (2002). "Fragmentation hurts Media Companies: CanWest Chief: Ottawa Citizen. 18 December 2002: C1.

Bean, Clive. (1998). "Class and Party in the Anglo-American Democracies: The Case of New Zealand in Perspective." British Journal of Political Science. 18.3: 303-321. 
Beck, Ulrich. (2001). "Globalization's Chernobyl: September 11 exposed Neoliberalism's Shortcomings as a Solution to the World's Conflicts, argues Beck." Financial Times (London). 25.

Bennett, Colin J and Robin Bayley. (1999). "The New Public Administration of Information: Canadian Approaches to Access and Privacy." Public Administration and Policy: Governing in Challenging Times. Ed. Martin W. Westmacott and Hugh P. Mellon. Scarborough, Ont.: Prentice-Hall. 189-201.

Bennett, W. Lance. (1988). News: The Politics of Illusion. New York: Longman.

Bennett, W. Lance. (1993). “A Policy Research Paradigm for the News Media and Democracy." Journal of Communication. 43.3: 439-456.

Benzie, Robert. (1997). “Bare Majority favors Merger: Poll.” Toronto Sun. 2 March 1997: 2.

Benzie, Robert. (1997). “'Mega’ Disaster for Homeless People.” Toronto Sun. 30 January 1997: 18.

Benzie, Robert. (2003). "Eves: I don't know who chose Auto Parts Site for TV Budget." Ottawa Citizen. 25 March 2003: A1.

Benzie, Robert. (2003).“Speaker condemns TV Budget as PR Event.” Ottawa Citizen. 9 May 2003: A1.

Bertram, Geoff. (1993). 'Keynesianism, Neoclassicism and the State." State and Economy in New Zealand. Ed. Brian Roper and Chris Rudd. Auckland: Oxford University Press. 26-49.

Bleyer, Peter. (1997). "Coalitions of Social Movements as Agencies for Social Change: The Action Canada Network." Organizing Dissent: Contemporary Social Movements in Theory and Practice. Toronto: Garamond. 102-117.

Blizzard, Christina. (1995). Right Turn: How the Tories took Ontario. Toronto: Dunburn Press.

Blizzard, Christina. (1997). "Sewell can't halt Changing Times." Toronto Sun. 22 February 1997: 2.

Blumler, Jay G. (1990). "Elections, the Media and the Modern Publicity Process." Public Communication: The New Imperative. Ed. Marjorie Ferguson. London: Macmillan. 101-113. 
Blumler, Jay G. (1997). “Origins of the Crisis for Citizenship." Political Communication. 14: 395-404.

Bobbio, Norberto. (1979). "Gramsci and the Conception of Civil Society." Gramsci and Marxist Theory. Ed. Chantal Mouffe. London: Routledge and Kegan Paul. 21-47.

Boix, Carles. (1997). "Privatizing the Public Business Sector in the Eighties: Economic Performance, Partisan Responses and Divided Government." British Journal of Political Science. 27: 473-496.

Boston, Jonathan. (1992). "The Treasury: Its Role, Philosophy and Experience." New Zealand Politics in Perpective. Ed. Hyam Gold. Auckland: Longman Paul. 68-91.

Boston, Jonathan and John Uhr. (1996). "Reshaping the Mechanics of Government." The Great Experiment: Labour Parties and Public Policy in Australia and New Zealand. Ed. Francis G. Castles, Rolf Gerritsen and Jack Vowles. Auckland: Auckland University Press. 48-67.

Boudreau, Julie-Anne. (2000). The Megacity Saga: Democracy and Citizenship in this Global Age. Montreal: Black Rose.

Bourdieu, Pierre. (1979). "Public Opinion doesn't exist." Communication and Class Struggle. Ed. Armand Mattelart and Seth Siegelaub. New York: International General. 124-130.

Bourdieu, Pierre. (2002). "Utopia of Endless Exploitation: The Essence of Neoliberalism." Le Monde diplomatique 8 December 1998. 2 November 2002: 1-7. $<\mathrm{http}: / /$ mondediplo.com/1998/12/08bourdieu>.

Bradford, Neil. (1998). "Prospects for Associative Governance: Lessons from Ontario, Canada." Politics and Society. 26.4: 539-573.

Bradford, Neil. (1999). "The Policy Influence of Economic Ideas: Interests, Institutions and Innovation in Canada." Studies in Political Economy. 59: 17-60.

Brearton, Steve. (2003). “Hopelessly De-voted.” This Magazine. July/August, 2003: 6.

Brennan, Richard. (1998). "Tories fight their 'Evil Image."' The Ottawa Citizen. 23 January 1998: A4.

Brennan, Richard. (1997). "Minister plotted 'to invent a crisis': Snobelen video spurs angry calls for him to resign." Toronto Star. 13 September 1997: A3.

Brennan, Richard. (2003). "Tories trying to buy Vote, NDP claims: Election Financing Request leaked: Conservatives seek \$8 Million Loan.” Globe and Mail. 8 March 2003: A19. 
Brennan, Richard and Caroline Mallan. (2003). "Tories feel confident they'll win next election; TV ads spotlight Eves' background; Party ready to go to polls this spring." Toronto Star. 20 February 2003: A7.

Bricker, Darrell. Personal communication, 11 November 2002.

Bricker, Darrell and Edward Greenspon. (2002). Searching for Certainty: Inside the New Canadian Mindset. Toronto: Anchor Canada, 2002.

Browne, Paul Leduc. (2001). "Unsafe Practices: Restructuring and Privatization in Ontario Health Care.” Ottawa: Canadian Centre for Policy Alternatives. 1-10.

Brownsey, Keith. (1999.). "Selling the Store: Privatizing Alberta's Liquor Stores." Public Administration and Policy: Governing in Challenging Times. Ed. Colin J. Bennett and Robin Bayley. Scarborough, Ont.: Prentice-Hall. 117-125.

Bruce, Brendan. (1992). Images of Power: How the Image Makers Shape our Leaders. London: Kogan Page.

Bruck, Peter A. (1989). "Strategies for Peace, Strategies for News Research." Journal of Communication. 39.1: 108-129.

Bruck, Peter A. (1992). “Discursive Movements and Social Movements: The Active Negotiation of Constraints." Democratic Communication in the Information Age. Ed. Janet Wasko and Vincent Mosco. Toronto: Garamond. 138-158.

Butler, David and Dennis Kavanaugh. (1980). The British General Election of 1979. London: Macmillan.

CAW (Canadian Auto Workers). (2002). "Task Force on Working Class Politics in the TwentyFirst Century: Recommendations to the CAW Collective Bargaining and Political Action Convention." Toronto: CAW. 1-19.

CBC (Canadian Broadcasting Corporation). (2000). "Battleground Calgary." Undercurrents. 15 October, 2000.

CC (Communication Canada). (2002). “Annual Report: Public Opinion Research in the Government of Canada, 2001-2002." Ottawa: Communication Canada.

CC (Communication Canada). (2002).“Listening to Canadians.” Ottawa: Communication Canada. 
CCPA (Canadian Centre for Policy Alternatives). (2003). "Reality Cheque: What Ontario Really needs (and it's not Tax Cuts!): The Ontario Alternative Budget 2003 Budget Document." March 2003. 1-45.

CH (Canadian Heritage Canada). (2003). "Media Studies: Concentration of Newspaper Ownership." 1-14. http://www/pch.gc.ca/progs/ac-ca/progs/esm-ms/prob3_e.cfm

CPBF (Campaign for Press and Broadcasting Freedom-Canada). (2002). "Free the Media: Concentrate on Media Ownership: It's still an Issue." 24 February 2002 $<\mathrm{http}: / /$ www.presscampaign.org/articles_12.html $>$.

CPBF (Campaign for Press and Broadcasting Freedom-Canada). (2002). "Media Ownership in Canada." <http://www.presscampaign.org/articles_12>.

CSU (Charles Sturt University). Business Studies. "Marketing." http://hsc.csu.edu.au/business_studies/marketing/marketing/marketing.html

CTV News. (1997). “The Ontario Teachers Strike." 4 November, 1997.

Cameron, David R. and Graham White. (2000). Cycling into Saigon: The Conservative Transition in Ontario. Vancouver: University of British Columbia Press.

Cameron, Duncan. (1991). "Beyond the Market and the State: How can We do better?" The New Era of Global Competition: State Policy and Market Power. Montreal \& Kingston: McGill-Queen's University Press. 435-447.

Campbell, Kim. (2002). “A Call to the Right.” Christian Science Monitor. 25 July 2002: 11. http://www.csmonitor.com/2002/0725/p11s01-ussc.htm

Campbell, Murray. (2003). “Queen's Park: Tories ramping up Pre-vote Ad Campaign.” Globe and Mail. 30 January 2003: A9.

Campbell, Murray. (2003). “Ontario PCs seek Millions for Election.” Globe and Mail. 8 March 2003: A5.

Canadian Encyclopedia. "Company of Young Canadians." Toronto: Historica Foundation of Canada. http://www.thecanadianencyclopedia.com/index.cfm?

Carr, Nancy. (2003). "Stronach unapologetic for $\$ 58.1 \mathrm{~m}$ Salary." Ottawa Citizen. 9 May 2003: E2.

Carroll, William K. (1997). "Introduction: Social Movements and Counter-Hegemony: Canadian Contexts and Social Theories." Organizing Dissent: Contemporary Social 
Movements in Theory and Practice. Ed. William Carroll. Toronto: Garamond Press. 1-19.

Carroll, William K. and Elaine Coburn. (2003). "Social Movements and Transformation." Changing Canada: Political Economy as Transformation. Ed. Wallace Clement and Leah F. Vosko. Montreal-Kingston: McGill-Queen's University Press. 79-105.

Cassidy, Sean. (1992). "The Environment and the Media: Two Strategies for Challenging Hegemony." Democratic Communication in the Information Age. Ed. Janet Wasko and Vincent Mosco. Toronto: Garamond Press. 159-174.

Castles, Francis G., Rolf Gerritson and Jack Vowles, eds. (1996). The Great Experiment: Labour Parties and Public Policy Transformation in Australia and New Zealand. Auckland: Auckland University Press.

Clarke, Harold D., Jane Jenson, Lawrence LeDuc and Jon H. Pammett. (1996). Canadian Electoral Politics in an Age of Restructuring. Calgary, AB.: Gage.

Clarke, John. (1992). "Ontario Social Movements - The Struggle Intensifies." Culture and Social Change: Social Movements in Quebec and Ontario. Ed. Colin Leys and Margaret Mendel. Montreal: Black Rose. 213-224.

Clarke, John and Daniel Maloy. (2003). "From Protest to Resistance: Ontario Coalition Against Poverty Organizer interviewed." Z-Net. Z-Magazine. 10 February 2003. $<\mathrm{http}$ //www.zmag.org/content/showarticle.cfm?SectionID=41\&It>.

Clarke, Tony. (1995). Challenging Corporate Rule in Canada. Ottawa: Council of Canadians.

Clarke, Tony. (1997). Silent Coup: Confronting the Big Business Takeover of Canada. Ottawa: Canadian Centre for Policy Alternatives; Toronto: James Lorimer \& Co.

Clarke, Tony. (2000). "Taking on the WTO: Lessons from the Battle of Seattle." Studies in Political Economy. 62: 7-16.

Clarkson, Stephen. (1993). “Constitutionalizing the Canadian-American Relationship." Canada under Free Trade. Ed. Duncan Cameron and Mel Watkins. Toronto: James Lorimer \& Co. 3-20.

Clarkson, Stephen. (2003). "Canadians fooled by Trade Deals Three Times - and Counting." CCPA Monitor. Canadian Centre for Policy Alternatives. 9: 6-9.

Clement, Wallace and Leah Vosko, eds. (2003). Changing Canada: Political Economy as Transformation. Montreal \& Kingston: McGill-Queen's University Press. 
Cleveland, Les. (1985). "The Sound and the Fury: Ideologically Motivated Pressure Groups." New Zealand Politics in Perspective. Ed. Hyam Gold. Auckland: Longman Press. 232-243.

Clift, Steven. (1998). "Democracy is Online." OnTheInternet. Internet Society. March-April. $<$ http://www.e-democracy.org/do/artide.html>.

Cohen, Ruth. (1998). "Alien Invasion: The Worst is Yet to Come." Alien Invasion: How the Harris Tories mismanaged Ontario. Ed. Ruth Cohen. Toronto: Insomniac Press. 15-16.

Cohen, Ruth and Bill Greaves. (1998). "Of Caterpillars and Butterflies: Reading John Snobelen's Infamous 'Caterpillar' Speech.” Alien Invasion: How the Harris Tories mismanaged Ontario. Ed. Ruth Cohen. Toronto: Insomniac Press. 130-133.

Cohen, Ruth, ed. (2001). Alien Invasion: How the Harris Tories mismanaged Ontario. Toronto: Insomniac Press.

Conway, Janet. (2000). "Knowledge, Power, Organization: Social Justice at a Crossroads." Studies in Political Economy. Summer: 43-70.

Cook, Timothy E. (1998). Governing with the News: The News Media as a Political Institution. Chicago, IL: University of Chicago Press.

Corcoran, Terence. (1997). “Ontario's Mega-Power Syndrome." Commentary. Report on Business. 7 February 1997: B2.

Crewe, Ivor. (1988). "Has the electorate become Thatcherite?" Thatcherism. Ed. Robert Skidelsky. London: Chatto and Windus. 25-39.

Crewe, Ivor. (1989). "Values: The Crusade that Failed." The Thatcher Effect: A Decade of Change. Ed. David Kavanagh and Anthony Seldon. Oxford: Oxford University Press. 239-250.

Crittendon, Guy. (1997). "The Harris Kremlin: Inside Ontario's Revolutionary Politburo." Globe and Mail. 1 November 1997: D1.

Crittendon, Guy. (1999). "Closed for Business.” Report on Business. June 1999: 51-60.

Crozier, Michel, Samuel P. Huntington and Joji Watanuki. (1975). The Crisis of Democracy: Report on the Governability of Democracies to the Trilateral Commission. New York: New York University Press.

Crump, John. Personal communication, 15 April 1998. 
Curran, James. (1990). "The Crisis of Opposition: A Reappraisal." The Alternative: Politics for a Change. Ed. Ben Pimlott and Tony Flower. London: W.H. Allen and Company. 231-241.

Curran, James. (1996). "Mass Media and Democracy Revisited." Mass Media and Society. Ed. James Curran and Michael Gurevitch. London: Arnold. 82-119.

Dale, Stephen. (1999). Lost in the Suburbs: A Political Travelogue. Toronto: Stoddart.

Dalton, Russell J. (2002). "Political Support in Advanced Industrial Democracies." Centre for the Study of Democracy, University of California, Irvine, CA. 9 September 2002. http://www.democ.uci.edu/democ/papers/dalton2.htm

Davis, Howard H. (1993). "Media Research: Whose Agenda?" Getting the Message: News, Truth and Power. GUMG (Glasgow University Media Group). London: Routledge. 34-49.

Deacon, David. (1996). "The Voluntary Sector in a Changing Communication Environment: A Case Study of Non-Official News Sources." European Journal of Communication. 11(2):173-199.

Deacon, David and Peter Golding. (1991). "When Ideology fails: The Flagship of Thatcherism and the British Local and National Media." European Journal of Communication. 6.3: 291-313.

Deacon, David and Peter Golding. (1994). Taxation and Representation: The Media, Political Communication and the Poll Tax. London: John Libbey.

Deacon, David and Wendy Monk. (2000). "Executive Stressed: News Reporting of Quangos in Britain." Press/Politics. 5.3: 45-66.

DeMara, Bruce. (1997). “Sewell urges Rebel Tories to buck One-City Drive: Leaders' Orders 'Unreasonable."' Toronto Star. 14 February 1997: A10.

DeMara, Bruce and Paul Moloney. (1997). "City spends $\$ 1,625,000$ on Mail Vote." Toronto Star. 14 January 1997: A6.

Democracy Watch. (1999). "Join our Coalition of Groups pushing for a Democratic Political Finance System in Canada." Ottawa: Democracy Watch.

$<$ http://www.democracywatch.ca $>$.

Democracy Watch. (2002). "Ban on One \$, One Vote? Money in Politics Campaign Update: Corporate Donors Dominate.” Citizen Action. Ottawa: Democracy Watch. 4-5. 
Donovan, Vincent. (1996). "Province, Union begin Warring Ad Blitzes." Toronto Star. 18 December 1996: A6.

De Mont, Philip and Eugene J. Lang. (1999). Turning Point: Moving beyond Neoconservatism. Toronto: Stoddart.

Dickinson, Greg M. (1998). “Court refuses to ground Ontario's Supersonic Educational Reforms." Education and Law Journal. May: 429-439.

Dobbin, Murray. (1998). The Myth of the Good Corporate Citizen: Democracy under the Rule of Big Business. Toronto: Stoddart.

Doucet, Clive. (2003). "Surreal Tory Show was 'just delightful”., Ottawa Citizen. 2 April 2003: C4.

Douglas, Roger O. (1993). Unfinished Business. Auckland: Random House.

Drummond, Robert J. and Robert MacDermid. (1997). "Elections and Campaigning: 'They blew our Doors off on the Buy."" The Government and Politics of Ontario. Ed. Graham White. Toronto: University of Toronto Press. 189-215.

Du Fresne, Karl. (1989). "Lobbying: New Zealand Style." New Zealand Politics in Perspective. Ed. Hyam Gold. Auckland: Longman Paul. 312-319.

Dunleavy, Patrick. (1989). "Liberal Democratic Politics: Pluralist and Marxist Views." New Zealand Politics in Perspective. Ed. Hyam Gold. $2^{\text {nd }}$ ed. Auckland: Longman Paul. 366-386.

Dunleavy, Patrick and Christopher T. Husbands. (1985). British Democracy at the Crossroads: Voting and Party Competition in the 1980s. London: Allen and Unwin.

Easton, Brian. (1989a). "The Commercialization of the New Zealand Economy: From Think Big to Privatization." The Making of Rogernomics. Auckland: Auckland University Press. 114-127.

Easton, Brian. (1989b). “The Unmaking of Roger Douglas." The Making of Rogernomics. Auckland: Auckland University Press. 171-185.

Easton, Brian. (1994). "How did the Health Reforms Blitzkrieg fail?" Political Science. 46.2: 215-233.

Easton, Brian and Rolf Gerritsen. (1996). "Economic Reform: Parallels and Divergences." The Great Experiment: Labour Parties and Public Policy Transformation in Australia and 
New Zealand. Ed. Francis G. Castles and Rolf Gerritsen. Auckland: Auckland University Press. 22-47.

Eder, Klaus. (1985). “The 'New Social Movements': Moral Crusades, Political Pressure Groups, or Social Movements?" Social Research. 52.4: 869-890.

Edgar, David. (1986). “The Free or the Good." Ideology of the New Right. Ed. Ruth Levitas. Cambridge, MA: Polity Press. 80-106.

Edgell, Stephen and Vic Duke. (1991). A Measure of Thatcherism: A Sociology of Britain in the 1990s. London: HarperCollins Academic.

Edgell, Stephen, Sandra Walklate and Gareth Williams. (1995). Debating the Future of the Public Sphere: Transforming the Public and Private Domains in Free Market Societies. Aldershot, UK: Avebury.

Ehring, George and Wayne Roberts. (1993). Giving away a Miracle: Lost Dreams, Broken Promises and the Ontario NDP. Oakville, Ont.: Mosaic.

Eldridge, John. (1993). "News, Truth and Power." Getting the Message: News, Truth and Power. GUMG (Glasgow University Media Group). London: Routledge. 3-33.

Ellwood, Wayne. The No-Nonsense Guide to Globalization. Toronto: New Internationalist and Between the Lines, 2001.

Entman, Robert M. (1993). "Framing: Toward Clarification of a Fractured Paradigm." Journal of Communication. 43.4: 51-58.

Environics. (1995). “Focus Ontario 1995-3: Fall Economic Statement.” [Sessional Paper No. 637.] 17 November 1995.

Environics. (1997). Focus Ontario. Toronto: Environics Research Group.

Epstein, Edward. (1973). News from Nowhere: Television and the News. New York: Random House.

Ericson, R., P. Baranek and J. Chan. (1989). Negotiating Control: A Study of News Services. Milton Keynes, UK: Open University Press.

Ernst, Alan. (1992). "From Liberal Continentalism to Neoconservatism: North American Free Trade and the Politics of the C.D. Howe Institute." Studies in Political Economy. 39: 109-140.

Fehir, Dena. (1996). “OPSEU leads Women's Charge.” Toronto Sun. 10 March 1996: 3. 
Femia, Joseph. (1975). "Hegemony and Consciousness in the Thought of Antonio Gramsci." Political Studies. 23.1: 29-48.

Femia, Joseph. (1993). Marxism and Democracy. Oxford: Clarendon Press.

Financial Post. (1997). Untitled Editorial. 28 January 1997: 18.

Finn, Ed. (2002). "Exposing the Business Propagandists: Corporate Public Relations Experts see People as a "Herd waiting to be led." Canadian Centre for Policy Alternatives. $<w w w . p o l i c y a l t e r n a t i v e s . c a /$ publications/articles/article305>.

Finn, Ed. (2002-2003). "Protesters should take Saul's Advice—with a Grain of Salt." CCPA Monitor. Canadian Centre for Policy Alternatives. December-January: 4.

FitzRandolph, Katie. Personal communication. 5 November 2001, 13 August 2002.

Fletcher, Fred. (2003). "Political Communication and Public Discourse." Robarts Centre for Canadian Studies. <www.robarts.yorku/canada>. 1-3

Fletcher, Frederick J. and Rose Sottile. (1997). "Spinning Tales: Politics and the News in Ontario." The Government and Politics of Ontario. Ed. Graham While. Toronto: University of Toronto Press. 236-267.

Flynn-Turner, June. (1997). "No Evidence fewer Trustees, Boards mean better Education." Ottawa Citizen. Letter to the editor. 3 June 1997: D5.

Globe and Mail. (1997). "Four Steps to Toronto.” 23 April 1997: A22.

Fox, Jennifer. (1996). “Sick Swan still needs Help.” Toronto Sun. 3 March, 1996: 34.

Francis, Diane. (1997). “Merger, Shmerger-Canadians simply want Lower Taxes." Financial Post. 16 January 1997: 13.

Franklin, Mark N. (1985). The Decline of Class Voting in Britain: Changes in the Basis of Electoral Choice, 1964-1983. Oxford: Clarendon.

Frankovic, Kathleen A. (1998). "Public Opinion and Polling." The Politics of News and the News of Politics. Washington, DC: CQ Press. 150-171.

Fraser Institute. (1996). "Toward the New Millennium: A Five Year Plan for the Fraser Institute." Vancouver: The Fraser Institute. 1-29.

Frum, David. (1997). “Amalgamated Toronto threatens Lefties' Political Machine.” Financial 
Post. 8 March 1997. 24.

GUMG (Glasgow University Media Group). (1993). Getting the Message: News, Truth and Power. London: Routledge.

Gagnon, Georgette and Dan Rath. (1991). Not without Cause: David Peterson's Fall from Grace. Toronto: HarperCollins.

Gamble, Andrew. (1983). "Thatcherism and Conservative Politics." The Politics of Thatcherism. Ed. Stuart Hall and Martin Jacques. London: Lawrence and Wishart. 109-131.

Gamble, Andrew. (1983). "Thatcher: The Second Coming." Marxism Today. July: 7-14.

Gamble, Andrew.(1993). The Free Economy and the Strong State: The Politics of Thatcherism. $2^{\text {nd }}$ ed. Basingstoke, UK: Macmillan.

Gandy, Oscar. (1987). Beyond Agenda-Setting: Information Subsidies and Public Policy. Norwood, NJ: Ablex Publishing.

Gans, Herbert. (1979). Deciding What's News. New York: Pantheon.

Gans, Herbert. (1985) “Are U.S. Journalists Dangerously Liberal?” Columbia Journalism Review. November-December: 32-33.

Garnham, Nicholas. (1982). "The Information Society." Information Technology: Impact on the Way of Life. Ed. Laim Bannon, Ursula Barry and Olav Holot. Dublin: Tycooly.

Garnham, Nicholas. (1982). "New Communications Technology." Information Technology: Impact on the Way of Life. A Selection of Papers from the EEC Conference on the Information Society. Ed. Liam Bannon, Ursula Barry and Glav Holot. Dublin: Tycooly. 18-20.

Garnham, Nicholas. (1986). "The Media and the Public Sphere." Communicating Politics: Mass Communication and the Political Process. Ed. Peter Golding, Graham Murdock and Philip Schlesinger. New York: Holmes and Meier. 37-53.

George, Susan. (1998). "A Short History of New-Liberalism." Alien Invasion: How the Harris Tories mismanaged Ontario. Ed. Ruth Cohen. Toronto: Insomniac Press. 184-193.

George, Susan. (1997). "How to win the War of Ideas: Lessons from the Gramscian Right." Dissent. 44.3: 47-53. 
Gill, Stephen. (1988). American Hegemony and the Trilateral Commission. Cambridge, UK: Cambridge University Press.

Gill, Stephen. (1992). "The Emerging World Order and European Change." New World Order: Socialist Register 1992. Ed. Leo Panitch and Ralph Miliband. London: Merlin Press. 157-196.

Gill, Stephen and David Law. (1988). The Global Political Economy: Perspectives, Problems, and Policies. New York: Harvester/Wheatsheaf.

Gindin, Sam.(2001). "Comment: Rebuilding the Left: Towards a Structured Anti-Capitalist Movement." Studies in Political Economy. 64: 91-97.

Ginsberg, Benjamin. (1982). The Consequences of Consent: Elections, Citizen Control, and Popular Acquiescence. Reading, MA: Addison-Wesley.

Ginsberg, Benjamin. (1986). The Captive Public: How Public Opinion promotes State Power. New York: Basic Books.

Girard, Daniel. (1996). “Injured Protester assails Police 'Extreme Violence'." Toronto Star. 20 March 1996: A10.

Girard, Daniel. (1996). "MPPs demand Public Inquiry into OPP Acts.” Toronto Star. 20 March 1996: A1.

Girard, Daniel. (1997). “'Slow down and get it right' Hall tells Province." Toronto Star. 7 February 1997: A8.

Girvan, Brian. (1994). The Right in the Twentieth Century: Conservatism and Democracy. London: Pinter.

Gitlin, Todd. (1980). The Whole World is Watching. Los Angeles, CA: University of California Press.

Gitlin, Todd. (1997). "Introduction." Conglomerates and the Mass Media. Ed. Patricia Aufderheide. New York: New Press. 7-13.

Globe and Mail. (1996). Untitled editorial. 20 March 1996: A22.

Globe and Mail. (1996). "Agrees with Foes of Cuts, Harris says Remarks spurred by Days of Action." 29 October 1996. A3.

Globe and Mail. (1998). “Ontario Labour shuts down City Hall.” 9 June 1998: A6. 
Gold, Hyam, ed. (1989). New Zealand Politics in Perspective. $2^{\text {nd }}$ ed. Auckland: Longman Paul,.

Gold, Hyam, ed. (1992). New Zealand Politics in Perspective. $3^{\text {rd }}$ ed. Auckland: Longman Paul.

Goldfinch, Shawn and Brian Roper. (1993). "Treasury's Role in State Policy Formulation during the Post-War Era." State Economy in New Zealand. Ed. Brian Roper and Chris Rudd. Auckland: Oxford University Press. 50-73.

Golding, Peter. (1990). "Political Communication and Citizenship: The Media and Democracy in an Inegalitarian Social Order." Public Communication: The New Imperatives. Ed. Marjorie Ferguson. London: Macmillan. 84-100.

Golding, Peter. (1992). "Communicating Capitalism: Resisting and Restructuring State Ideology.” Media, Culture and Society. 14.4: 503-522.

Golding, Peter. (1994). "Media Research and the New Communications Map: The Twin Crises of European Communications." Nordicom Review. 1:7-16.

Golding, Peter. (1994). "Telling Stories: Society, Journalism and the Informed Citizen." European Journal of Communication. 9.4: 461-484.

Golding, Peter. (1995). "The Mass Media and the Public Sphere: The Crisis of Information in the Information Society." Debating the Future of the Public Sphere: Transforming the Public and Private Domains in Free Market Societies. Ed. Stephen Edgell, Sandra Walklate and Gareth Williams. Aldershot, UK: Avebury. 25-40.

Golding, Peter and Philip Elliott. (1979). Making the News. London: Longman.

Golding, Peter, Graham Murdock and Philip Schlesinger. (1986). Communicating Politics: Mass Communications and the Political Process. Leicester, UK: Leicester University Press.

Golding, Susan R. (1992). Gramsci's Democratic Theory: Contributions to a Post-Liberal Democracy. Toronto: University of Toronto Press.

Gordon, Charles. (1997). "What a Wicked Web they weave." Ottawa Citizen. 11 March 1997: A6.

Goldstein, Lorrie. (1997). “Don't delay, call Mel today.” Toronto Sun. 16 February, 1997: C3.

Graber, Doris, Denis McQuail and Pippa Norris, eds. (1998). The Politics of News: The News of Politics. Washington, DC: CQ Press. 
Gramsci, Antonio. (1971). Selections from the Prison Notebooks. Trans. by Geoffrey Nowell Smith. London: Lawrence and Wishart.

Gray, Gratton. (1990). “Social Policy by Stealth.” Policy Options. 11.2: 17-29.

Gray, John. (1996). “OPSEU fighting Uphill Battle for Support." Globe and Mail. 15 March 1996. A1.

Gustafson, Barry. (1986). The First 50 Years: A History of the New Zealand National Party. Auckland: Reed Methuen.

Haas, Dr. Richard and Oliver Knox. (1991). Politics of Thatcherism: Thoughts from a London Thinktank. Lanham, MD: University Press of America.

Habermas, Jurgen. (1975). Legitimation Crisis. Trans. Thomas McCarthy. Boston, MA: Beacon Press.

Habermas, Jurgen. (1981). “New Social Movements.” Telos. 49: 33-37.

Hackett, Bob with Donald Glustein. (2003). "Vancouver's Largest Papers are Imbalanced—Are You Surprised?" NewsWatch Monitor. 4.1: 1-2.

Hackett, Robert. (1984). "Decline of a Paradigm? Bias and Objectivity in News Media." Critical Studies in Mass Communications. 1.3: 229-259.

Hackett, Robert. (1991). News and Dissent: The Press and the Politics of Peace in Canada. Norwood, NJ: Ablex.

Hackett, Robert. (2000). "Taking Back the Media: Notes on the Potential for a Communicative Democracy Movement." Studies in Political Economy. 63: 61-87.

Hackett, Robert, Richard Pinet and Myles Ruggles. (1996). "News for Whom?: Hegemony and Monopoly versus Democracy in Canadian Media." Seeing Ourselves: Media Power and Policy in Canada. Ed. Helen Holmes and David Taras. Toronto: Harcourt Brace \& Co. 257-272.

Hackett, Robert and Yuezhi Zhao. (1998). Sustaining Democracy? Journalism and the Politics of Objectivity. Toronto: Garamond Press.

Halifax Initiative. (2002). "The Bretton Woods Institutions." http://www.halifaxinitiative.org/index 
Hall, Peter A.(1989). The Political Power of Economic Ideas: Keynesianism across Nations. Princeton, NJ: Princeton University Press.

Hall, Stuart. (1985). “Faith, Hope or Clarity.” Marxism Today. 29.1: 15-19.

Hall, Stuart. (1988a). The Hard Road to Renewal. London: Verso.

Hall, Stuart. (1988b). "Toad in the Garden: Thatcherism among the Theorists." Marxism and the Interpretation of Culture. Ed. Carr Nelson and Lawrence Grossberg. Champaign, IL: University of Illinois Press. 110-132.

Hall, Stuart. (1989). "Ideology and Communication Theory." Rethinking Communication. Ed. Brenda Dervin, Lawrence Grossberg, E.J. O’Keefe and Ellen Wartella. Vol. 1. Newbury Park, DA: Sage. 40-52.

Hall, Stuart. (1996). "The Problem of Ideology: Marxism without Guarantees." Stuart Hall: Critical Dialogues in Cultural Studies. Ed. David Morley and Kuan Hsing Chen. London : Routledge. 25-46.

Hall, Stuart, Chas Critcher, Tony Jefferson, John Clarke and Brian Roberts. (1978). Policing the Crisis: Mugging, the State, and Law and Order. London: Macmillan.

Hall, Stuart and David Held. (1989). "Citizens and Citizenship." New Times: The Changing Face of Politics in the 1990s. Ed. Stuart Hall and Martin Jacques. London: Lawrence and Wishart. 173-188.

Hall, Stuart and Martin Jacques. (1984). The Politics of Thatcherism. London: Lawrence and Wishart.

Hall, Stuart and Martin Jacques, eds. (1989). New Times: The Changing Face of Politics in the 1990s. London: Lawrence and Wishart.

Hall, Stuart, Bob Lumley and Gregor McLennan. (1977). "Politics and Ideology: Gramsci." Working Papers in Cultural Studies 10. Birmingham, UK: University of Birmingham. 45-76.

Hansen, Anders and Graham Murdock. (1985). "Constructing the Crowd: Populist Discourse and Press Presentation." The Critical Communications Review. Vol. 3. Ed. Vincent Mosco and Janet Wasko. Norwood, NJ: Ablex. 227-257.

Harder, Jeff. (1997). “Tories seek Legal Muscle.” Toronto Sun. 29 October 1997: 4.

Harder, Jeff and Philip Lee-Shanok. (1996). "Palladini blasts Snowplow Operators." Toronto Sun. 5 March 1996: 2. 
Harder, Jeff and Antonella Artuso. (1996). "Harris orders Probe into Riot." Toronto Sun. 29 March 1996: 4.

Harder, Lois. (1996). "Depoliticizing Insurgency: The Politics of the Family in Alberta." Studies in Political Economy. 50: 37-64.

Harris, David. (1992). From Class Struggle to the Politics of Pleasure: The Effects of Gramscianism on Cultural Studies. London: Routledge.

Harris, Paul. (1989). "Pressure Groups and Protest." New Zealand Politics in Perspective. Ed. Hyam Gold. $2^{\text {nd }}$ ed. Auckland: Longman Paul. 295-311.

Hartmann, Paul. (1975-1976). "Industrial Relations News in the Mass Media." Industrial Relations Journal. 6 (Winter): 4-18.

Hazen, Don. (1996). "Seeking Vision: 10 Steps toward fighting Media Monopoly." Media and Democracy. Ed. Don Hazen and Larry Smith. San Fransisco, CA: Institute for Alternative Journalism. 161-164.

Hazen, Don and Larry Smith, eds. (1996). Media and Democracy. San Francisco, CA: Institute for Alternative Journalism.

Held, David. (1986). "Introduction: New Forms of Democracy?" New Forms of Democracy. Ed. David Held and Christopher Pollitt. London: Sage. 1-13.

Held, David. (1989). “The Decline of the Nation State." New Times: The Changing Face of Politics in the 1990s. Ed. Stuart Hall and Martin Jacques. London: Lawrence and Wishart. 191-204.

Herbst, Susan. (1993). Numbered Voices: How Opinion Polling has shaped American Politics. Chicago, IL: University of Chicago Press.

Herman, Edward and Noam Chomsky. (1988). Manufacturing Consent: The Political Economy of the Mass Media. New York: Pantheon Books.

Herman, Edward and Robert McChesney. (1997). The Global Media: The New Missionaries of Global Capitalism. London: Cassell.

Hermer, Joe and Janet Mosher. (2002). Disorderly People: Law and the Politics of Exclusion in Ontario. Halifax: Fernwood Publishing.

Hetherington, Alastair. (1989). "The Mass Media." The Thatcher Effect: A Decade of Change. Ed. Dennis Kavanagh and Anthony Seldon. Oxford: Oxford University Press. 290-304. 
Howlett, Michael. (1997). "Issue-Attention and Punctuated Equilibria Models Reconsidered: An Empirical Examination of the Dynamics of Agenda-Setting in Canada." Canadian Journal of Political Science. 30.1: 3-29.

Ibbitson, John. (1997). Promised Land: Inside the Mike Harris Revolution. Scarborough, Ont.: Prentice-Hall.

Ibbitson, John. (2001). Loyal No More: Ontario's Struggle for a Separate Destiny. Toronto: HarperCollins.

Ibbitson, John and Jim Poling. (1996). “Ontario PS reach Deal to end Strike.” Toronto Star. 29 March 1996: A1.

Ingham, Bernard. (1991). Kill the Messenger. London: HarperCollins.

Ipsos-Reid. (1995a). "Provincial Politics: The Ontario Election." The Angus Reid Report. July/August. 54-65.

Ipsos-Reid. (1995b). “National Trade Unionists Study Results.” 1 September. 1-10.

Ipsos-Reid. (1995c). “Ontario Finance Survey.” 12-0334-04. [Sessional Paper No. 640.] 12 December. 1-10.

Ipsos-Reid. (1996a). "Ontario Government Survey." 12-1043-15. [Sessional Paper No. 642-3.] 8 April.

Ipsos-Reid. (1996b). Ontario Government Survey." 02-1043-16. [Sessional Paper No. 642-1.] 8 April.

Ipsos-Reid. (1996c). “Ontario Government Survey.” 02-1043-18. [Sessional Paper No. 642-2.] 8 April.

Ipsos-Reid. (1996f). "Municipal Reform Issues." 02-1043-22. [Sessional Paper No. 537.] 11 November.

Ipsos-Reid. (1997a). "Public Policy Focus: Public Opinion on Issues on the Policy Front." The Angus Reid Report. November/December. 31-44.

Ipsos-Reid. (1997b). “Post-Budget Add-Ons.” 02-1994-01. [Sessional Paper No. 643.] June. Ipsos-Reid. (1997c). “Topline Questionnaire.” [Sessional Paper No. 639.] September. 
Ipsos-Reid. (1997d). "Majority of Ontarians opposed to Strike by Teachers." News Release. 24 October. 1-2.

Ipsos-Reid. (1997e). “The Ontario Political Scene.” News release. 16 December. 1-3.

Ipsos-Reid. (1997f). "Public Policy Focus: Public Opinion on Issues on the Policy Front." The Angus-Reid Report. November/December. 31-44.

Ipsos-Reid. (1998). “The Ontario Political Scene.” News release. 23 February. 1-3.

Ipsos-Reid. (1999). "Provincial Politics: The '99 Ontario Election." The Angus-Reid Report. May-June. 63-67.

Isin, Engin. (1998)."Governing Toronto without Government: Liberalism and Neoliberalism." Studies in Political Economy. 56: 169-191.

Isin, Engin and Joanne Wolfson. (1999). The Making of the Toronto Megacity: An Introduction. Toronto: Urban Studies Program.

Iyengar, Shanto. (1997). "Framing Responsibility for Political Issues: The Case of Poverty." Do the Media govern? Politicians, Voters and Reporters in America. Ed. Shanto Iyengar and Richard Reeves. Thousand Oakes, CA: Sage. 276-282.

Jacek, Henry J. (1997). “The New World of Interest-Group Politics.” The Government and Politics of Ontario. Ed. Graham White. Toronto: University of Toronto Press. 307-327.

Jackson, Andrew. (2001). "Can there be a 'Second Way' in the Third Millennium?" Studies in Political Economy. 65: 39-65.

Jacques, Martin. (1983). "Thatcherism: Breaking out of the Impasse." The Politics of Thatcherism. Ed. Stuart Hall and Martin Jacques. London: Lawrence and Wishart. 4062.

Jakubowicz, Karol. (1993). "Stuck in a Groove: Why the 1960s Approach to Communication Democratization Will No Longer Do." Communications and Democracy. Ed. Slavko Splichal and Janet Wasko. Norwood, NJ: Ablex. 33-54.

Jakubowicz, Karol. (1999). "Public Service Broadcasting in the Information Society." Media Development. 2: 45-49.

Jasperson, Amy E., Dhavan V. Shah, Mark Watts, Ronald J. Faber and David P. Fan. (1998). "Framing and the Public Agenda: Media Effects on the Importance of the Federal Deficit Budget." Political Communication. 15: 205-224. 
Jenson, Jane. (1989). “'Different,' but not 'Exceptional': Canada's Permeable Fordism.”

Canadian Review of Society and Anthropology. 26.1: 69-94.

Jenson, Jane. (1993). “All the World's a Stage: Ideas, Spaces and Time in Canadian Political Economy." Production, Space, Identity: Political Economy faces the Twenty-first Century. Ed. Jane Jenson, Rianne Mahon and Manfred Bienefeld. Toronto: Canadian Scholars' Press. 143-169.

Jesson, Bruce. (1988). "From Libertarianism to Socialism." Revival of the Right: New Zealand Politics in the 1980s. Ed. Bruce Jesson, Allanah Ryan and Paul Spoonley. Auckland: Heinemann Reid. 117-119.

Jesson, Bruce, Allanah Ryan and Paul Spoonley, eds. (1988). Revival of the Right: New Zealand Politics in the 1980s. Auckland: Heinemann Reed.

Jesson, Bruce. (1992). "Lobbying and Protest: Patterns of Political Change at the Informal Level." New Zealand Politics in Perspective. Ed. Hyam Gold. $3^{\text {rd }}$ ed. Auckland: Longman Paul. 365-378.

Jessop, Bob. (1983). “Accumulation Strategies, State Forms, and Hegemonic Projects.” Kapitalistate, 13: 89-111.

Jessop, Bob. (1985). Nikos Poulantzas: Marxist Theory and Political Strategy. London: Macmillan.

Jessop, Bob. (1989). "Conservative Regimes and the Transition to Post-Fordism: The Cases of Britain and West Germany." Capitalist Development and Crisis Theory: Accumulation, Regulation and Spacial Restructuring. Ed. M. Gottdiener and Nicos Komninos. New York: St. Martins Press. 261-299.

Jessop, Bob. (1997). “A Neo-Gramscian Approach on the Regulation of Urban Regimes: Accumulation Strategies, Hegemonic Projects, and Governance." Reconstructing Urban Regime Theory. Ed. Mickey Lauria. Thousand Oaks, CA: Sage. 51-73.

Jessop, Bob, Kevin Bonnett and Simon Bromley. (1990). "Farewell to Thatcherism? NeoLiberalism and New Times." New Left Review. 179: 81-102.

Jessop, Bob, Kevin Bonnett, Simon Bromley and Tom Ling. (1984). “Authoritarian Populism, Two Nations and Thatcherism." New Left Review. 147: 32-60.

Jessop, Bob, Kevin Bonnett, Simon Bromley and Tom Ling. (1988). Thatcherism: A Tale of Two Nations. Cambridge, MA: Polity Press.

Josey, Stan. (1997). “Megacity losing Ground?” Toronto Star. 13 February, 1997: SC1. 
Kaihla, Paul. (1998). "Selling out or selling off? Mike Harris's Tories are taking Heat from the Business Community for failing to deliver on Privatization Pledge." Canadian Business 71(17): 22-24.

Karim, Karim H. (1993). "Reconstructing the Multicultural Community in Canada: Discursive Strategies of Inclusion and Exclusion." International Journal of Politics. 7.2: 189-207.

Karlberg, Michael and Robert A. Hackett. (1996). "Cancelling Each Other Out? Interest Group Perceptions of the Mass Media." Canadian Journal of Communication. 21.4S: 461-472.

Kavanagh, Dennis. (1987). Thatcherism and British Politics: The End of Consensus. Oxford: Oxford University Press.

Kavanagh, Dennis and Anthony Seldon, eds. (1989). The Thatcher Effect: A Decade of Change. Oxford: Oxford University Press.

Keane, John. (1991). Media and Democracy. Cambridge, MA: Polity Press.

Keil, Roger. (1998). “Toronto in the 1990s: Dissociated Governance?” Studies in Political Economy. 56: 151-168.

Kelsey, Jane. (1994). "Aotearoa/New Zealand: The Anatomy of a State in Crisis." Leap into the Dark: The Changing Role of the State in New Zealand since 1984. Ed. Andrew Sharp. Auckland: Auckland University Press. 178-205.

Kelsey, Jane. (1995). The New Zealand Experiment: $A$ World Model for Structural Adjustment. Auckland: Auckland University Press.

Kelsey, Jane. (1999). Reclaiming the Future: New Zealand and the Global Economy. Toronto: Toronto University Press, 1999.

Kennedy, Dan. (1996). "Making Sense of Merger Mania." Media and Democracy. Ed. Dan Hazen and Larry Smith. San Francisco, CA: Institute for Alternative Journalism. 8-14.

Kielbowicz, Richard B. and Clifford Scherer. (1986). "The Role of the Press in the Dynamics of Social Movements.” Research in Social Movements, Conflict and Change. 9: 71-96.

Kidder, Annie. Personal communication. 7 April 2003.

King, Desmond. (1987). The New Right: Politics, Markets, and Citizenship. Basingstoke, UK: Macmillan Education. 
Kipfer, Stefan. (1998). “Urban Politics in the 1990s: Notes on Toronto.” Possible Urban Worlds. Ed. Inura Zurich. Zurich, CH: ETH. 172-179.

Klandermans, Bert and Sidney Tarrow. (1988). "Mobilization into Social Movements: Synthesizing European and American Approaches." International Social Movement Resistance. Ed. Bert Klandermans, Hanspeter Kriesi and Sidney Tarrao. Vol. 1. Greenwich, CT: JAI Press. 1-38.

Klein, Seth. (1996). “Good Sense versus Common Sense: Canada's Debt Debate and Competing Hegemonic Projects." M.A. Diss. Department of Political Science, Simon Fraser University.

Knight, Graham. (1982). "Strike Talk: A Case Study of News." Canadian Journal of Communication. 8 (2): 61-79.

Knight, Graham. (1998). "Hegemony, the Press and Business Discourse: Coverage of StrikeBreaker Reform in Quebec and Ontario.” Studies in Political Economy. 55: 93-125.

Korten, David C. (1990). Getting to the Twenty-first Century: Voluntary Action and the Global Agenda. West Hartford, CT: Kumarian Press,.

Korten, David C. (1995). When Corporations Rule the World. West Hartford, CT: Kumarian Press.

Korten, David C. (1998). The Post-Corporate World: Life after Capitalism. San Francisco, CA: Berrett-Koehler.

Kozolanka, Kirsten. (2001). "The New TVOntario: Salvation or Suicide for Public Education Broadcasting." Canadian Journal of Communication. 26: 53-68.

Kozolanka, Kirsten. (2002). "Too Far, Too Fast: The Mobilization of Parents against NeoLiberal Education Restructuring in Ontario." Civic Discourse and Cultural Politics in Canada: A Cacophony of Voices. Ed. Sherry Devereaux Ferguson and Leslie Regan Shade. Stamford, CT: Ablex Publishing. 128-141.

Laclau, Ernesto and Chantal Mouffe. (2001). Hegemony and Socialist Strategy: Towards a Radical Democratic Politics. London: Verso.

Langille, David. (1987). "The Business Council on National Issues and the Canadian State." Studies in Political Economy. 24: 41-85.

Larner, Wendy. (1996). “A Means to an End: Neoliberalism and State Processes in New Zealand." Studies in Political Economy. 52: 7-38. 
Larner, Wendy. (2000). 'Neo-liberalism: Policy, Ideology, Governmentality." Studies in Political Economy. 63: 5-25.

Latter, Jacqueline. Personal communication. 21 March 1998.

Laux, Jeanne Kirk. (1991). "Shaping or Serving Markets: Public Ownership after Privatization." The New Era of Global Competition: State Policy and Market Power. Ed. Daniel Drache and Meric S. Gertler. Montreal \& Kingston: McGill-Queen's University Press. 288-315.

Laxer, James. (1996) In Search of A New Left: Canadian Politics after the Neoconservative Assault. Toronto: Viking.

Laxer, James. (1996). “One Way or Another, Most will make Harris' Hit List,”Toronto Star. 24 March 1996: F3

Laxer, James. (1996). "Listen to the Protesters, not the Media." Toronto Star. 4 November 1996: A15.

Lehrer, Ute Angelika. (1998). "Is there still Room for Public Space? Globalizing Cities and the Privatization of the Public Realm." Possible Urban Worlds. Ed. Inura Zurich. Zurich, CH: ETH. 200-207.

Levine, Gregory J. (1997). "Disclosure of Information and Protection of Privacy Legislation." Administrative Law and Practice. August:1-23.

Levine, Stephen and Nigel S. Roberts. (1989). "Parties, Leaders, and Issues in the 1987 Election." New Zealand Politics in Perspective. Ed. Hyam Gold. Auckland: Longman Paul. 423-445.

Levitas, Ruth, ed. (1986). The Ideology of the New Right. Cambridge, MA: Polity Press.

Levy, Sheldon H., Dyane Adam and Gerry Smith. (1998). "What We heard about TVOntario." Report of the TVOntario Community Forum Panel. Toronto.

Leys, Colin. (1985). "Thatcherism and British Manufacturing: A Question of Hegemony." SNID Occasional Paper. No. 85-102. Kingston, Ont.: Programme of Studies in National and International Development, Queen's University. 1-30.

Leys, Colin. (1990). "Still a Question of Hegemony." New Left Review. 181: 119-128.

Leys, Colin and Marguerite Mendell, eds. (1992). Culture and Social Change: Social Movements in Quebec and Ontario. Montreal: Black Rose. 
Lindgren, April. (2003). “Dalton McGuinty, Version 2003." Ottawa Citizen, 10 February 2003: A4.

Lindgren, April. (2002). "Protests actually help us: Tories." Ottawa Citizen. 22 July 2002: A6.

Lipsey, Richard, ed. (1990). Zero Inflation: The Goal of Price Stability. Policy Study 8. Toronto: C.D. Howe Institute.

Lisac, Mark. (1995). The Klein Revolution. Edmonton: NeWest Press.

Long, Thomas. (1995). "What the Conservative Win in Ontario means for All of Canada." Fraser Forum: 5-14.

Lyon, David. (1988). The Information Society: Issues and Illusions. Cambridge, UK: Cambridge University Press.

MEdT (Ministry of Education and Training. Ontario). (1997a). "Contingency Plan: Communications Support Team.” Communications plan.

MEdT (Ministry of Education and Training. Ontario). (1997b). "Critical Path for Bill 106 [sic] Stakeholder Relations." Confidential draft. Communications plan.

MEdT ( Ministry of Education and Training. Ontario). (1997c). "Critical Path for Discussions with the OTF and its Affiliates." Communications plan. Confidential draft.

MEdT ( Ministry of Education and Training. Ontario). (1997d). "Critical Path to respond to Possible OTF Work Action." Confidential Draft. Communications plan. 1997d.

MEdT (Ministry of Education and Training. Ontario). (1997e). "Principals and VicePrincipals." Issue sheet. 13 November.

MEdT ( Ministry of Education and Training. Ontario). (1997f). "Reforms to take Education off Property Tax, meet Students' Needs." News release. 13 January.

MEdT ( Ministry of Education and Training. Ontario). (1997g). "New Legislation ensures Quality Education." News release. 22 September.

MMAH ( Ministry of Municipal Affairs and Housing. Ontario). (1996a). "Study shows One Toronto would save Taxpayers $\$ 300$ Million a Year.” News release. 16 December.

MMAH (Ministry of Municipal Affairs and Housing. Ontario). (1996b). "Unifed Toronto to save Money, Jobs." Backgrounder. 17 December. 
MMAH ( Ministry of Municipal Affairs and Housing. Ontario). (1996c). "Unifed Toronto to save Money, Jobs." News release. 17 December.

MMAH (Ministry of Municipal Affairs and Housing. Ontario). (1997a). "Better Services at a Lower Cost will Trigger Savings for Taxpayers." News release. 13 January.

MMAH (Ministry of Municipal Affairs and Housing. Ontario). (1997b). “Ads to Explain Plans for Better, Less Costly Government." News Release. 14 January.

MMAH (Ministry of Municipal Affairs and Housing. Ontario). (1997c). "Huge Potential for Property Tax Cuts." News release. 17 January.

MMAH ( Ministry of Municipal Affairs and Housing. Ontario). (1997d). "Speech by Education and Training Minister John Snobelen, 'Who does What'.' Speech. 17 January 1997.

MMAH ( Ministry of Municipal Affairs and Housing. Ontario). (1997e). "Communication Plan: New Toronto Transition Team." Communications plan. 26 February.

MMAH ( Ministry of Municipal Affairs and Housing. Ontario). (1997f). "One Toronto." Issue sheet. 7 March.

MMAH (Ministry of Municipal Affairs and Housing. Ontario). (1997g). "Amendments to Bill 103 address Public Input." News release. 27 March.

MMAH (Ministry of Municipal Affairs and Housing. Ontario). (1997h). "One Toronto Amendments; Process." Issue sheet. 1 April.

MORI (Market \& Opinion Research International. (2002). "Political Attitudes and Trends: Satisfaction Ratings: 1979--Present." MORI Political Monitor.

$<$ http://www.mori.com/polls/trends/satisfac.shtml >.

Maarek, Phillipe. (1995). Political Marketing and Communication. London: John Libbey.

MacBride, Sean et al. (1980). Many Voices, One World: Towards a New More Just and More Efficient World Information and Communication Order. London: Kogan Page/New York:Unipub/Paris: UNESCO.

MacDermid, Robert. (1997)."TV Advertising Campaigns in the 1995 Ontario Election." Revolution at Queen's Park: Essays on Governing Ontario. Ed. Sid Noel. Toronto: James Lorimer \& Company. 74-106.

MacDermid, Robert. (c1999). "Funding the Common-Sense Revolutionaries: Contributions to the Progressive Conservative Party of Ontario, 1995-97." Toronto, Ontario: Centre for Social Justice. 1-54. 
MacDermid, Robert. (2000). "Tories tipped the Odds in Ontario Election." Straight Goods. 6 June $<$ http://www.straightgoods.com/item378.asp>. 1-4.

MacDermid, Robert. (2001). "Tories tipped the Cards in Ontario Election." Alien Invasion: How the Harris Tories mismanaged Ontario. Ed. Ruth Cohen. Toronto: Insomniac Press. 17-19.

MacDermid, Robert. (c2003). "Money and the 1999 Election." Robarts Centre for Canadian Studies. <http://www.robarts.yorku/canada>.

Mackie, Richard. (1997). "Public-sector Unions target Bill 136: CUPE Leaders to seek Mandate to organize Strike across Ontario in Fall." Globe and Mail. 8 July 1997: A1.

Mackie, Richard. (1997). "Ontario PCs flip-flop to regain Popularity: U-Turns made with Election in Mind." Globe and Mail. 29 September 1997: A1.

Mackie, Richard. (1997). "Defy Strike Call, Harris urges: Set to walk out Monday, Ontario Teachers open Door a Chink on Conditions for Dialogue." Globe and Mail. 23 October, 1997: A1.

Mackie, Richard. (1998). "Pickets put aside to launch Campaign." Globe and Mail. 28 July 1998: A3.

Mackie, Richard and Christopher Harris. (1997). "Private Bid for TVO weighed, Not-for-profit Pitch revealed." Globe and Mail. 27 June 1997: A1.

Mackie, Richard, Jennifer Lewington and Thomas Claridge. (1997). "School Strike Ruling Expected this Weekend." Toronto Star. 1 November 1997: A1.

Macleod, Catherine. (1999). "Introduction." Celebration of Resistance: Ontario's Days of Action. Vincenzo Pietropaolo. Toronto: Between the Lines.

Magnish, Scott and Ciaran Ganley. (1996). “Cops, Union clash: Pickets hurt: Rowdy Queen's Park Siege.” Toronto Sun. 9 March 1996: 2.

Mahon, Rianne. (1993). “The 'New' Canadian Political Economy Revisited.” Production, State, Identity: Political Economy faces the Twenty-first Century. Ed. Jane Jenson, Rianne Mahon and Manfred Bienefeld. Toronto: Canadian Scholars' Press Inc. 1-21.

Mallan, Caroline. (2003). "Chipping away at the Power of the Legislature: Tories curb Role of Backbench MPPs: Rule Changes began with Harris.” Toronto Star. 31 May 2003: H1. 
Manzer, Ronald. (1999). "Political Ideas in Policy Analysis: Educational Reform and Canadian Democracy in the 1990s." Public Administration and Policy: Governing in Challenging Times. Ed. Colin J. Bennett and Robin Bayley. Scarborough, Ont.: Prentice-Hall. 155165.

Marleau, Robert and Camille Montpetit. (2000). House of Commons Procedures and Practice. Montreal: Chelneliere/McGraw-Hill.

Marsh, David, M.J. Smith and D. Richards. (2000). "Bureaucrats, Politicans and Reform in Whitehall: Analyzing the Bureau-Shaping Model." British Journal of Political Science. 30: 461-482.

Massey, Doreen. (1983). “The Contours of Victory .... Dimensions of Defeat." Marxism Today. July: 16-19.

Mattelart, Armand. (1980). Mass Media, Ideologies and the Revolutionary Movement. Brighton, UK: Harvester.

Mauser, Gary A. (1983). Political Marketing: An Approach to Campaign Strategy. New York: Praeger.

McAllister, Ian and Jack Vowles. (1944). "The Rise of New Politics and Market Liberalism in Australia and New Zealand." British Journal of Political Science. 24: 381-402.

McBride, Stephen. (1992). Not Working: State, Unemployment and Neo-Conservatism in Canada. Toronto: University of Toronto Press.

McBride, Stephen. (1996). "The Continuing Crisis of Social Democracy: Ontario's Social Contract in Perspective." Studies in Political Economy. 50: 65-94.

McCann, Wendy. (1995). "TVO braces for Tory Privatization Push: Network Head says Private Sector would be hard pressed to do better for less than \$60-million Annual Budget." Globe and Mail. 23 June, 1995: C9.

McCarthy, Thomas. (1973). "Translator's Introduction." Legitimation Crisis. Ed. Jurgen Habermas. Boston, MA: Beacon Press. vii-xxiv.

McChesney, Robert W. (1997). Corporate Media and the Threat to Democracy. New York: Seven Stories Press.

McChesney, Robert W. (2002). Our Media, Not Theirs: The Democratic Struggle against Corporate Media. New York: Seven Stories Press. 
McCormack, Judith. (1999). "Comment on the Politicization of the Ontario Labour Relations Framework in the 1990s." Canadian Labour and Employment Journal. 7:325-353.

McCormick, Thomas J. (1989). America's Half Century: United States Foreign Policy in the Cold War. Baltimore, MD: Johns Hopkins University Press.

McKercher, Catherine. (2002). Newsworkers Unite: Labour, Convergence and North American Newspapers. Lanham, MD: Rowman \& Littlefield.

McNair, Brian. (1994). News and Journalism in the UK. London: Routledge.

McQuaig, Linda. (1995). Shooting the Hippo: Death by Deficit and Other Canadian Myths. Toronto: Viking.

Meldon, Hugh. (1999). "Budgets and Governing Arrangements: The Political Functions of Budgets." Public Administration and Policy: Governing in Challenging Times. Ed. Colin J. Bennett and Robin Bayley. Scarborough, Ont.: Prentice-Hall.

Mercer, Colin. (1980). "Revolutions, Reforms or Reformations? Marxist Discourse on Democracy." Marxism and Democracy. Ed. Alan Hunt. London: Lawrence and Wishart. 102-137.

Merritt, Davis. (1998). Public Journalism and Public Life: Why telling the News is not enough. Mahwah, NJ: Erlbaum.

Miliband, Ralph. (1985). "The New Revisionism in Britain." New Left Review. 150: 5-26.

Miller, Mark Crispin.(1996). "Demonopolize Them! A Call For a Broad-based Movement against the Media Trust." Media and Democracy. Ed. Don Hazen and Larry Smith. San Francisco, CA: Institute for Alternative Journalism. 15-20.

Mills, Russell. (2003). "CanWest Plan a Threat to Local Independence." Globe and Mail. 22 January 2003: B11.

Minkenberg, Michael. (2001). "The Radical Right in Public Office: Agenda-Setting and Policy Effects." West European Politics. 24, 1-21.

Mittelstaedt, Martin.(1996). “Talks to resume in OPSEU Walkout.” Globe and Mail. 9 March 1996: A1.

Mittelstaedt, Martin. (1996). "Quick Resolution of Ontario Strike remains Remote: Mediator begins to sound out Each Side for any Flexibility." Globe and Mail. 11 March 1996. A2. 
Mittelstaedt, Martin. (1996). "Shutdown of Toronto would make History: Labour risks alienating an Inconvenienced Public." Globe and Mail. 19 October, 1996. A1.

Mittelstaedt, Martin. (1999). “The \$136,000 Fax." Report on Business Magazine June: 44-46.

Mittelstaedt, Martin and Gay Abbate. (1996). "Ontario fears Unrest in Jails." Globe and Mail. 1 March 1996: Al.

Mittelstaedt, Martin and James Rusk. (1996). "Police, Pickets clash in Ontario: Scuffling with Striking Civil Servants erupts as Ministers try to enter Legislature." Globe and Mail. 19 March 1996: Al.

Mittelstaedt, Martin and James Rusk. (1996). "Plans for Fledgling Social Movement getting Bigger." Globe and Mail. 26 October 1996: A6.

Mooers, Colin and Alan Sears. (1992). "The 'New Social Movements' and the Withering Away of State Theory." Organizing Dissent: Contemporary Social Movements in Theory and Practice. Ed. William K. Carroll. Toronto: Garamond Press. 52-68.

Moloney, Paul. (1997). “'No' Forces surging in Metro Mayors’ Poll.” Toronto Star. 27 February 1997: A9.

Molotch, Harvey and Marilyn Lester. (1974). "News as Purposive Behaviour: On the Strategic Use of Routine Events, Accidents and Scandals." American Sociological Review. 39 (February): 101-112.

Morley, David. (1976). "Industrial Conflict and the Mass Media." Sociological Review. 24 (1976) 2: 245-268.

Morrison, Ian. (1997). "Rights and the Right: Ending Social Citizenship in Tory Ontario." Mike Harris's Ontario: Open for Business, Closed to People. Ed. Diana Ralph, André Régimbald and Nérée St-Amand. Halifax: Fernwood. 68-78.

Mosco, Vincent. (1982). Pushbutton Fantasies: Critical Perspectives on Videotex and Information Technology. Norwood, NJ: Ablex.

Mosco, Vincent. (1996). The Political Economy of Communication. London: Sage.

Mosco, Vincent. (2003). "The Transformation of Communication in Canada." Changing Canada: Political Economy as Transformation. Ed. Wallace Clement and Leah F. Vosko. Montreal-Kingston: McGill-Queen's University Press. 287-308.

Mosco, Vincent and Eileen Mahoney. (1985). "Introduction." The Critical Communications Review. Ed. Vincent Mosco and Janet Wasko. Vol. 3. Norwood, NJ: Ablex. x-xix. 
Mosco, Vincent and Patricia Mazepa. (2003).'High Tech Hegemony: Transforming Canada's Capital into Silicon Valley North." Globalization, Media Hegemony, and Social Class. Ed. Lee Artz and Yahya Kamalipour. New York: State University of New York Press, forthcoming.

Mouffe, Chantal. (1979). "Introduction: Gramsci Today." Gramsci and Marxist Theory. Ed. Chantal Mouffe. London: Routledge and Kegan Paul. 1-18.

Mulgan, Geoff. (1994). Politics in an Antipolitical Age. Cambridge, MA: Polity Press.

Mulgan, Richard. (1992). "The Elective Dictatorship in New Zealand." New Zealand Politics in Perspective. Ed. Hyam Gold. ${ }^{\text {rd }}$ ed. Auckland: Longman Paul. 513-532.

Munro, Marcella. (1997). “Ontario's 'Days of Action' and Strategic Choices for the Left in Canada." Studies in Political Economy. 53: 125-140.

Murdock, Graham and Peter Golding. (1977). "Capitalism, Communication and Class Relations." Mass Communication and Society. Ed. Michael Gurevitch and Janet Wollacott. Beverley Hills, CA: Sage Publications. 12-43.

Murdock, Graham and Peter Golding. (1989). "Information Poverty and Political Inequality: Citizenship in the Age of Privatized Communication." Journal of Communication. 39.3: 180-195.

NCC (National Citizens' Coalition). (2003). "NCC battles Gag Laws." NCC-Online. 19 January. $<$ http://www.morefreedom.org/ $>$.

NCC (National Citizens' Coalition). (2002). "The NCC's Political Friends and Enemies." Reform Watch. http://www.web.net/ refwatch/policy/ncc3.htm

Nagel, Jack H. (1994). "What Political Scientists can learn from the 1993 Electoral Reform in New Zealand." PS: Political Science and Politics. 27: 525-29.

Nagel, Jack H. (1998). "Social Choice in a Pluralitarian Democracy: The Politics of Market Liberalization in New Zealand." British Journal of Political Science. 28: 223-267.

Negrine, Ralph. (1996). The Communication of Politics. London: Sage.

Neilson, David. (1998). "State Autonomy and the Mode of Political Regulation: Neo-Liberal Restructuring in New Zealand." Studies in Political Economy. 57: 45-71.

Nemeth, Thomas. (1980). Gramsci's Philosophy: A Critical Study. Brighton, UK: The Harvester Press. 
Nesdoly, Tracy. (1996). "Poll: They're striking out." Toronto Sun. 1 March 1996: 5.

Noel, Sid, ed. (1997). “Ontario's Tory Revolution." Revolution at Queen's Park: Essays on Governing in Ontario. Ed. Sid Noel. Toronto: Lorimer.

Noel, Sid, ed. (1997). Revolution at Queen's Park: Essays on Governing in Ontario. Toronto: Lorimer.

Nolan, Michael. (1999). "Case Study in Regulation: CTV and Canadian Broadcast Policy." Public Administration and Policy: Governing in Challenging Times. Ed. Colin J. Bennett and Robin Bayley. Scarborough, Ont.: Prentice-Hall. 126-135.

Norris, Pippa, ed. (1999). Critical Citizens: Global Support for Democratic Government. Oxford: Oxford University Press.

OCAP (Ontario Coalition Against Poverty). (2003). "No Second Trial for Three Accused." 12 May. www.ocap.ca

OISE (Ontario Institute for Studies in Education). (1996). "Highlights of the $11^{\text {th }}$ OISE Survey of Educational Issues." www.utoronto.ca/OISE-Survey/hilites.html

OISE (Ontario Institute for Studies in Education). (1998). "Highlights of the 1998 OISE Survey." www.utoronto.ca/OISE-Survey/hilites.html

ONG. (2002). "Censoring Censorship." Ottawa Newspaper Guild . Newsletter. April 2002: 1.

ONG. (2002). "Chronology of Events." Ottawa Newspaper Guild. Newsletter. April 2002: 4

OPSEU (Ontario Public Sector Employees Union). (1996a). “Gagged!” Picket Lines, 16 March. 1.

OPSEU (Ontario Public Services Employees Union). (1996b). “Ideas and Options for OPSEU's Communication Strategy." Report. Toronto: OPSEU, 13 January.

OPSEU (Ontario Public Services Employees Union). (1996c). “Snowplow.” Taped advertisement.

OPSEU (Ontario Public Sector Employees Union). (2002). "Tory Advertising tops $\$ 3.1$ Million for OPSEU Strike." New Release. 30 July.

OTF (Ontario Teachers' Federation). (1998). “Ontario's Teachers: A Case Study in Gaining Public Support." Media panel discussion to the Public Affairs Association of Canada. 
Offe, Claus. (1985a). Disorganized Capitalism: Contemporary Transformations of Work and Politics. Oxford: Polity Press.

Offe, Claus. (1985b). "New Social Movements: Challenging the Boundaries of Institutional Politics." Social Research. 52.4: 817-868.

Oliver, Hugh. (1989). "The Labour Caucus and Economic Policy Formulation, 1981 to 1984." The Making of Rogernomics. Ed. Brian Easton. Auckland: Auckland University Press. 11-52.

Ontario Court (General Division). (1997). Toronto Region. "Reason for Judgement." Court file No. 97-cv-134721. 3 November.

O Siochru, Sean. (1996). "Strategies and Opportunities for Democratic Media." Media Development. 3: 3-7.

Ottawa Citizen. (1995). "Rae regrets not cutting Public Service sooner." 22 April 1995: A5.

Palmer, Jerry. (2002). "Smoke and Mirrors: Is that the Way it is? Themes in Political Marketing." Media, Culture and Society. 24: 345-363.

Panitch, Leo. (1994). "Globalization and the State." Socialist Register 1994. Ed. Ralph Miliband and Leo Panitch. London: Merlin Press.

Panitch, Leo and Ralph Miliband. (1992)."The New World Order and the Socialist Agenda." New World Order. Ed. Ralph Miliband and Leo Panitch. London: Merlin Press. 1-25.

Panitch, Leo and Donald Swartz. (1988). From Consent to Coercion Revisited: The Assault on Trade Union Freedoms. Toronto: Garamond.

Paquette, Jerry. (1998). "Re-engineering Ontario Education: The Process and Substance of the Harris Reforms in Education in Ontario." Education and Law Journal. December: 1-41.

Parkland Institute. (2002). 'Neo-Liberal Globalism and its Challenges: Sustainability in the Semi-Periphery." Parkland Institute, Calgary. $<$ http://www.ualberta.ca/PARKLAND/mcri $>$.

Patten, Steve. (1996). "Preston Manning's Populism: Constructing the Common Sense of the Common People." Studies in Political Economy. 50: 95-132.

Patterson, Thomas E. (1994). Out of Order: How the Decline of Political Parties and the Growing Power of News Media Undermine the American Way of Electing Presidents. New York: Vintage Books. 
Perloff, Richard M. (1998). Political Communication: Policy, Press and Public in America. Mahwah, NJ: Lawrence Erlbaum Associates.

Toronto Life. (1996). "Peter and the Wolves." July: 56-61.

Phillips, Louise. (1996). "Rhetoric and the Spread of the Discourse of Thatcherism." Discourse \& Society. 7.2: 209-241.

Picard, Robert G. (1998). "Media Concentration, Economics, and Regulation." The Politics of News and the News of Politics. Ed. Doris Graber, Denis McQuail and Pippa Norris. Washington, DC: CQ Press. 193-217.

Pieczka, Magda. (2002). "Public Relations Expertise Deconstructed." Media, Culture and Society. 24: 301-323.

Pieczka, Magda and Philip Schlesinger. (2002). "Editorial." Media, Culture and Society. 24.3: 299-300.

Pimlott, Ben, Anthony Wright and Tony Flower. (1990). The Alternative: Politics for a Change. London: W.H. Allen and Company.

Political Studies Association. (2003). "PMG: Public Marketing Group." http://www/psa.ac.uk/spgrp/polmarket/polmarketing.htm

Pollara. (1997). “Overnight Education/Nightly Tracking.” [Sessional Papers Nos. 202/204.] October-November.

Poulantzas, Nicos. (1978). State, Power, Socialism. London: NLB.

Progressive Conservative Party of Ontario. (1994). Common Sense Revolution. Toronto.

Raboy, Marc. (1984). Movements and Messages: Media and Radical Politics in Quebec. Toronto: Between the Lines.

Raboy, Marc. (1996). "Public Television." The Cultural Industries in Canada. Ed. Michael Dorland. Toronto: Lorimer.

Rachlis, Chuck and David Wolfe. (1997). “An Insider's View of the NDP Government in Ontario: The Politics of Permanent Opposition meets the Economics of Permanent Recession." The Government and Politics of Ontario. Ed. Graham White. Toronto: University of Toronto Press. 331-364. 
Ralph, Diana S. (1997). "Strategies for the Post-Harris Era." Open for Business, Closed to People: Mike Harris's Ontario." Ed. Diana Ralph, André Régimbald and Nérée StAmand, eds. Halifax: Fernwood. 177-185.

Ralph, Diana, André Régimbald and Nérée St-Amand, eds. (1997). Mike Harris 's Ontario: Open for Business, Closed to People. Halifax: Fernwood.

Ransome, Paul. (1992). Antonio Gramsci: A New Introduction. London: Harvester Wheatsheaf.

Rapaport, David. (1999). No Justice, No Peace: The 1996 OPSEU Strike against the Harris Government in Ontario. Montreal \& Kingston: McGill-Queen's University Press.

Ratner, R.S. (1997). "New Movements, New Theory, New Possibilities? Reflection on Counter-Hegemony Today." Organizing Dissent: Contemporary Social Movements in Theory and Practice. Ed. William Carroll. Toronto: Garamond Press. 234-243.

Red Pepper. (2002). "New Labour's Snakes and Ladders.” 100:22-25.

Reilly, Susan Smith. (1996). "Geopolitics, Media, and the Public Sphere.” Political Communication Research: Approaches, Studies and Assessments. Norwood, NJ: Ablex. 27-39.

Rich, Andrew and R. Kent Weaver. (2000). "Think Tanks in the U.S. Media." Press/Politics. 5.4: 81-103.

Richardson, Robin M. (1995). "Reducing Government Debt the New Zealand Way: Some Lessons for Canada." Fraser Forum. October: 18-19.

Riddell, Peter. (1983). The Thatcher Government. Oxford: Martin Robertson and Company Limited.

Rigsbee, Ed. (2000). Developing Strategic Alliances. Menlo Park, CA: Crisp Publications, Inc.

Roberts, Alasdair. (1998). Limited Access: Assessing the Health of Canada's FOI Laws. Kingston, Ont.: School of Policy Studies, Queen's University.

Roberts, Alasdair. (1999). "Retrenchment and FOI: Recent Experience under Federal, Ontario and B.C. Law." Canadian Public Administration. 42.4: 422-51.

Roberts, Alasdair. (2001). "Structural Pluralism and the Right to Information." University of Toronto Law Journal. Summer: 243-271.

Roberts, Alasdair. (2002). “Access to Information: Opportunistic Secrecy." Ottawa Citizen 15 October 2002: A5. 
Robinson, William I. (1996a). "Globalization, the World System, and 'Democracy Promotion' in U.S. Foreign Policy." Theory and Society. 25: 617-665.

Robinson, William I. (1996b). Globalization, U.S. Intervention, and Hegemony. Cambridge, UK: Cambridge University Press.

Rooney, Frank. Personal communication. 22 November 2002.

Roper, Brian. (1993). “A Level Playing Field? Business Political Activism and State Policy Formulation." State and Economy in New Zealand. Ed. Brian Roper and Chris Judd. Auckland: Oxford University Press. 147-171.

Roper, Brian and Chris Rudd, eds. (1993). State and Economy in New Zealand. Auckland: Oxford University Press.

Rose, Jonathan. (2000). Making 'Pictures in our Heads': Government Advertising in Canada. Westport, CN: Praegar, 2000.

Rose, Nikolas. (1997). “Governing 'Advanced' Liberal Democracies.” 1996. Foucault and Political Reason: Liberalism, Neo-Liberalism and Rationalities of Government. Ed. Andrew Barry, Thomas Osborne and Nikolas Rose. Chicago, $\mathbb{L}$ : University of Chicago Press Larner. 37-64.

Rose, Richard. (1983). "Two and One-half Cheers for the Market in Britain." Public Opinion. June-July: 10-15.

Rosen, Jay. (1996). "Public Journalism: A Movement Rethinking the Goals and Practices of the American Press." Media and Democracy. Ed. Don Hazen and Larry Smith. San Francisco, CA: Institute for Alternative Journalism. 100-102.

Rosenberg, Julie. Personal communication. 13 September 2002.

Ross, Ijeoma. (1997). "Half of Etobicoke Residents oppose Amalgamation: Six Municipalities are using Four Different Voting Methods to conduct Plebiscites that end on Monday." Globe and Mail. 25 February 1997. A3.

Ross, ljeoma and Gay Abbate. (1997)."Petition calls for Metro to secede if Votes ignored: Responsibility Swap galvanizing Both Sides of Amalgamation Issue." Globe and Mail. 21 January 1997: A3.

Ross, Ijeoma and James Rusk. (1997). “Court backs Challenge of Megacity Trustees.” Globe and Mail. 26 February 1997. A1. 
Ross, Val and Elizabeth Renzetti. (1997). "Will Megacity cripple the Arts? Groups fear Indiscriminate Streamlining." Globe and Mail. 5 March 1997: C1.

Rotman, Richard. (1996). "Public Relations: OPSEU Strike tests Communicators' Skills." Strategy. 15 April 1996: 12.

Ruimy, Joel. (1997). "Harris lashes out at Teacher Unions." Toronto Star. 24 November 1997: A24.

Ruryk, Zen. (1997). “We're making Tough Decisions: Leach defends Amalgamation to Spirited Crowd." Toronto Sun. 12 February 1997: 4.

Ruryk, Zen and James Wallace. (1997). “It's a Megamajority No to Supercity: Voters overwhelmingly reject Amalgamation." Toronto Star. 4 March 1997: A4.

Rusk, James. (1996). “MPPs demand Inquiry into Riot Squad's Violence: Opposition asks why OPP charged Public-Service Pickets at Legislature: Metro Police criticize Fellow Officers." Globe and Mail. 20 March 1996: A5.

Rusk, James. (1996). "Metro to become One Big City: Leach to announce today Tories' Plan to amalgamate Six Municipalities in Toronto Region." Globe and Mail. 17 December, 1996: A1.

Rusk, James. (1997). “Tories stand firm on Control of Policy: Teachers won't set Rules, Harris says." Globe and Mail. 1 October 1997: A3.

Rusk, James and Gay Abbate. (1997). "Leach complains Plebiscites are rigged, possibly Illegal." Globe and Mail. 31 January 1997: A5.

Ryan, Charlotte. (1991). Prime Time Activism: Media Strategies for Grassroots Organizing. Boston, MA: South End Press.

Rykert, Liz. Personal communication. 2 May 2003, 27 May 2003.

SMI (Social Marketing Institute). (2003). "Social Marketing." http://www.socialmarketing.org/sm.html

Salutin, Rick. (1997). "Press fails the Test of covering Ontario Teachers Strike." Globe and Mail. 31 October 1997: C1.

Sassoon, Anne Showstack. (1980). "Gramsci: A New Concept of Politics and the Expansion of Democracy." Marxism and Democracy. Ed. Alan Hunt. London: Lawrence and Wishart. 81-99. 
Sassoon, Anne Showstack. (2001). "Globalization, Hegemony, and Passive Revolution." New Political Economy. 6 (1): 5-17.

Savoie, Donald J. (1994). Thatcher, Reagan and Mulroney: In Search of a New Bureaucracy. Toronto: University of Toronto Press.

Scannell, Paddy, Philip Schlesinger and Colin Sparks, eds. (1992). Culture and Power: A Media, Culture and Society Reader. London: Sage.

Schechter, Danny. (1996). "Making Media work: Why We must get beyond Disneyland Journalism." Media and Democracy. Ed. Don Hazen and Larry Smith. San Francisco, CA: Institute for Alternative Journalism. 2-7.

Schlesinger, Philip. (1989). "From Production to Propaganda." Media, Culture and Society. 11: 283-306.

Schlesinger, Philip. (1990). "Rethinking the Sociology of Journalism: Source Strategies and the Limits of Media-Centrism." Public Communication: The New Imperative. Ed. Marjorie Ferguson. London: Macmillan. 61-83.

Schlesinger, Philip, Graham Murdock and Philip Elliot. (1983). Televising 'Terrorism': Political Violence in Popular Culture. London: Comedia Publishing Group.

Schmid, Christian. (1998). "The Politics of Urbanism." Possible Urban Worlds. Zurich, CH: ETH. 144-6.

Schudson, Michael. (1998). "The Public Journalism Movement and its Problems." The Politics of News and the News of Politics. Ed. Doris Graber, Denis McQuail and Pippa Norris. Washington, DC: CQ Press. 132-149

Schwartz, Herman. (1997). "Reinvention and Retrenchment: Lessons from the Application of the New Zealand Model to Alberta, Canada." Journal of Policy Analysis and Management. 16: 205-232.

Scott, Jane. (1997). “Communication Campaigns and the Neo-liberal Policy Agenda." Media, Culture and Society. 19.2: 183-199.

Scott, Jane. (1995). "Neo-Liberalism at Work: Media-Politics and the Employment Contracts Act." M.A. Diss. University of Auckland.

Sears, Alan. (1999). “The 'Lean' State and Capitalist Restructuring: Towards a Theoretical Account." Studies in Political Economy. 59: 91-114. 
Segal, Hugh. (1997). Beyond Greed: A Traditional Conservative confronts Neoconservative Excess. Toronto: Stoddart.

Segal, Hugh. (1997). "Less going on than meets the Eye in Megacity Hysteria." Financial Post. Commentary. 22 February 1997: 28.

Semetko, Holli A., Jay G. Blumler, Michael Burevitch and David H. Weaver with Steve Barkin and G. Cleveland Wilhoit. (1991). The Formation of Campaign Agendas: A Comparative Analysis of Party and Media Roles in Recent American and British Elections. London: Lawrence Erlbaum Associates.

Sharp, Andrew, ed. (1994). Leap into the Dark: The Changing Role of the State in New Zealand since 1984. Auckland: Auckland University Press.

Simon, Roger. (1982). Gramsci's Political Thought: An Introduction. London: Lawrence and Wishart.

Simpson, Jeffrey. (1980). Discipline of Power: The Conservative Interlude and the Liberal Restoration. Toronto: Macmillan.

Skidelsky, Robert, ed. (1988). Thatcherism. London: Chatto and Windus.

Smith, Dan. (1996). "Battling for the Heart: It's not a given that the Harris Government will win the Tug-of-War with its Workers for Public Support." Toronto Star. 2 March 1996: B1.

Small, Peter. (1997a). "Lessons from the Teachers' Strike." Toronto Star. 9 November 1997: A1.

Small, Peter. (1997b). "Pro-Tory Voter Move against Bill 160." Toronto Star. 21 November 1997: A1.

Snow, David A. and Robert D. Benford. (1988). "Ideology, Frame Resonance, and Participant Mobilization." International Social Movement Research. Ed. Gert Klandermas, Hanspeter Kriesi and Sidney Tarrow. Vol. 1. Grenwich, CT: JAI Press Inc. 197-217.

Sparks, Colin. (1992). "The Popular Press and Political Democracy." Culture and Power: A Media, Culture and Society Reader. Ed. Paddy Scannell, Philip Schlesinger and Colin Sparks. London: Sage. 278-292.

Sparks, Colin. (1993). "Raymond Williams and Democratic Communication." Communication and Democracy. Ed. Slavko Splichal and Janet Wasko. Norwood, NJ: Ablex. 69-86. 
Spears, John. (1997). “'No' to Megacity if Taxes Unprotected: Poll." Toronto Star, 1 March 1997: A1.

Speirs, Rosemary. (1986). Out of the Blue: The Fall of the Tory Dynasty in Ontario. Toronto: Macmillan, 1986.

Splichal, Slavko. (1993). "Searching for New Paradigms: An Introduction." Communication and Democracy. Ed. Slavko Splichal and Janet Wasko. Norwood, NJ: Ablex. 3-18.

Spoonley, Paul, Bruce Jesson and Allanah Ryan. (1988). "The Revival of the Right." Revival of the Right: New Zealand Politics in the 1980s. Ed. Bruce Jesson, Allanah Ryan and Paul Spoonley. Auckland: Heinemann Reed. 5-29.

Stan, Adele M. (1995). “Power Preying.” Mother Jones. November-December: 1-12.

Stanford, Jim. "The Economics of Debt and the Remaking of Canada." Studies in Political Economy. 48 (1995): 113-135.

Stanford, Jim. Paper Boom: Why Real Prosperity requires a New Approach to Canada's Economy. Ottawa: Canadian Centre for Policy Alternatives and Lorimer, 1999.

Stauber, John and Sheldon Rampton. (2001). Trust Us, We're Experts. New York: PenguinPutnam.

Steinem, Gloria. (1995). "Sex, Lies and Advertising." Gender, Race and Class in Media: A Text-Reader. Ed. Gail Dines and Jean M. Humez. Thousand Oaks, CA: Sage. 112-120.

Stephenson, Hugh. (1980). Mrs. Thatcher's First Year. London: Jill Norman Ltd.

Stevenson, Randolph T. and Lynn Vavreck. (2000). "Does Campaign Length Matter? Testing for Cross-National Effects." British Journal of Political Science. 30: 217-235.

Taft, Kevin. (1997). Shredding the Public Interest: Ralph Klein and 25 Years of One-Party Government. Edmonton: University of Alberta Press.

Tanguay, Brian A. (1997). "'Not in Ontario!' From the Social Contract to the Common Sense Revolution." Revolution at Queen's Park: Essays on Governing Ontario. Ed. Sid Noel. Toronto: Lorimer. 18-37.

Taras, David. (2001). Power and Betrayal in the Canadian Media. Peterborough, Ont.: Broadview Press.

Tarrow, Sidney. (1998). Power in Movement: Social Movements and Contentious Politics. $2^{\text {nd }}$ ed. Cambridge, UK: Cambridge University Press. 
Taylor, Alison. (2001). The Politics of Education Reform in Alberta. Toronto: University of Toronto Press.

Thatcher, Margaret. (1995). The Path to Power. New York: HarperCollins.

Thompson, John B. (1984). Studies in the Theory of Ideology. Cambridge, MA: Polity Press.

Thompson, John B. (1990). Ideology and Modern Culture: Critical Social Theory in the Era of Mass Communications. Cambridge, MA: Polity Press.

Thompson, John Herd. (1992). “Canada's Quest for 'Cultural' Sovereignty': Protection, Promotion and Popular Culture." Seeing Ourselves: Media Power and Policy in Canada. Ed. Helen Holmes and David Taras. Toronto: Harcourt Brace Jovanovich Canada.

Tiffen, Rodney. (1989). News and Power. Sydney: Allen and Unwin.

Todd, Graham. (1995). "Going Global in the Semi-periphery: World Cities as Political Projects. The Case of Toronto." World Cities in a World System. Ed. Paul Knox and Peter Taylor. Cambridge, UK: Cambridge University Press. 192-212.

Todd, Graham. (1998). "Megacity: Globalization and Governance in Toronto." Studies in Political Economy. 56: 293-216.

Toronto Star. (1996). Untitled editorial. 20 March 1996: A22.

Toronto Star. (1997). "Delay Election, but pass Unification Bill.” Editorial. 15 February 1997: E2.

Toronto Star. (1997). “Don’t pass Bill 160 without Major Surgery." Editorial. 22 November, 1997: C2.

Toronto Star. (1997). "Impact of Bill 160 remains to be seen." Editorial. 2 December 1997: A18.

Toronto Star. (1997). “Order, Please!” Editorial. 5 December 1997: A36

Toronto Star. (1997). "Tory Credibility on Schools is Shattered." Editorial. 25 October 1997: E2.

Toronto Sun. (1997). "Self-preservation." Untitled editorial. 25 January, 1997: 10. 
Toughill, Kelly and Lisa Wright. (1996). “Two Sides dig in: Province, Union talk Hard Strike." Toronto Star. 27 February 1996: A1.

Travis, Alan. (2002). “Public Record Office: 1971: Thatcher curbs on 'Radicals' foiled." Guardian, 1 January 2002.

http://www.politics.guardian.co.uk.print/0.3858,4327481,00.html

Turk, James. (1997). "Challenging the Harris Corporate Agenda." Mike Harris's Ontario: Open for Business, Closed to People. Ed. Diana Ralph, André Régimbald and Nérée StAmand. Halifax: Fernwood. 165-176.

Underwood, Doug. (1998). "Market Research and the Audience for Political News." The Politics of News and the News of Politics. Ed. Doris Graber, Denis McQuail and Pippa Norris. Washington, DC: CQ Press. 171-192.

Urquhart, Ian. (1997a). “Tory MPPs won’t break Ranks on Megacity.” Toronto Star. 3 April 1997: A25.

Urquhart, Ian. (1997b). "Race for Top Post reveals Crack in House of Labour." Toronto Star. 1 November 1997: E5.

Urquhart, Ian. (1998). "Liberals could benefit in Labour's Anti-Harris War." Toronto Star. 30 July 1998: A17.

Valpy, Michael. (1997). "What She catches in the Web." Globe and Mail. 7 February 1997: A15.

Van Rijn, Nicholas. (1996). "Strikers show a 'Hang Tough' Spirit on Lines." Toronto Star. 22 March 1996: A4.

Vipond, Mary. (2000). The Mass Media in Canada. $3^{\text {rd }}$ ed. Toronto: Lorimer.

Vowles, Jack. (1985). "Business and Labour: Major Organised Interests in the Politcal Economy of New Zealand." New Zealand Politics in Perspective. Ed. Hyam Gold. $1^{\text {st }}$ ed. Auckland: Longman Paul. 216-231.

Vowles, Jack. (1989). "Business, Unions and the State: Organizing Economic Interests in New Zealand." New Zealand Politics in Perspective. Ed. Hyam Gold. $2^{\text {nd }}$ ed.. Auckland: Longman Paul. 275-294.

Walkom, Thomas. (1994). Rae Days: The Rise and Follies of the NDP. Toronto: Key Porter Books. 
Walkom, Thomas. (1997). "The Harris Government: Restoration or Revolution." The Government and Politics of Ontario. Toronto: University of Toronto Press. 402-417.

Walkom, Thomas. (1997). "Striking Teachers triumph despite Fracture of Unions." Toronto Star. 7 November, 1997: A6.

Wallerstein, Immanuel. (1990). "Antisystemic Movements: History and Dilemmas." Transforming the Revolution: Social Movements and the World-System. Ed. Samir Amin, Giovanni Artighi, André Gunder Frank and Immanuel Wallenstein. New York: Monthly Review. 1-53.

Wallerstein, Immanuel. (1992). "The Collapse of Liberalism." New World Order? Socialist Register 1992. Ed. Leo Panitch and Ralph Miliband. London: Merlin Press. 96-110.

Walljasper, Jay. (1996). “Do We still need the Alternative Press?" Media and Democracy. Ed. Don Hazen and Larry Smith. San Francisco, CA: Institute for Alternative Journalism. 142-144.

Walsh, Pat. (1993). "The State and Industrial Relations in New Zealand." State and Economy in New Zealand. Ed. Brian Roper and Chris Judd. Auckland: Oxford University Press. 172-191.

Wanagas, Don. (1997). “Merger a 'No': Poll.” Toronto Sun. 27 February 1997: 7.

Warnock, John W. (1988). Free Trade and the New Right Agenda. Vancouver: New Star Books.

Warskett, Rosemary. (1992). "Defining Who We are: Solidarity through Diversity in the Ontario Labour Movement." Culture and Social Change. Ed. Colin Leys and Marguerite Mendell. Montreal: Black Rose. 109-127.

Wasko, Janet. (1993). "Introduction: Studies in Communication Democracy." Communication and Democracy. Ed. Slavko Splichal and Janet Wasko. Norwood, NJ: Ablex: 163-167.

Wasko, Janet and Vincent Mosco, eds. (1992). Democratic Communications in the Information Age. Toronto: Garamond.

Watson, Steve. (1997). "Ontario Workers take on the Common Sense Revolution." Mike Harris's Ontario: Open for Business, Closed to People. Ed. Diana Ralph, André Régimbald and Nérée St-Amand. Halifax: Fernwood. 134-142.

Weaver, C. Kay and Judy Motion. (2002). "Sabotage: Public Relations Democracy and Genetic Engineering in New Zealand." Media, Culture and Society. 24: 325-43. 
Weinroth, Michelle. (1997). "Deficitism and Neo-Conservatism in Ontario." Open for Business: Closed to People: Mike Harris's Ontario. Ed. Diana Ralph, André Régimbald and Nérée St-Amand. Halifax: Fernwood. 54-67.

Whitcombe, Judy. (1989). "The Changing Face of the New Zealand Public Service." New Zealand Politics in Perspective. Ed. Hyam Gold. Auckland: Longman Paul. 154-170.

White, Graham, ed. (1997). The Government and Politics of Ontario. 5th ed.. Toronto: University of Toronto Press.

Williams, Raymond. (1968). Communications. Hammondworth, UK: Penguin Books.

Williams, Raymond. (1973). "Base and Superstructure in Marxist Cultural Theory." New Left Review. 82: 3-16.

Williams, Raymond. (1977). Marxism and Literature. Oxford: Oxford University Press.

Williamson, John. (1994a). "In Search of a Manual for Technopols." The Political Economy of Policy Reform. Ed. John Williamson. Washington, DC: Institute for International Economics. 11-28.

Williamson, John, ed.(1994b). The Political Economy of Policy Reform. Washington, DC: Institute for International Economics.

Williamson, John and Stephen Haggard. (1994). "The Political Conditions for Economic Reform.” The Political Economy of Policy Reform. Ed. John Williamson. Washington, DC: Institute for International Economics. 527-594.

Winfield, Mark S. and Greg Jenish. (1998). “Ontario's Environment and the 'Common Sense Revolution."” Studies in Political Economy. 57: 129-145.

Winseck, Dwayne. (2002). "Netscapes of Power: Convergence, Consolidation and Power in the Canadian Mediascape." Media, Culture and Society. London: Sage Publications. 795819.

Wiseman, Nelson. (1997). "Change in Ontario Politics." The Government and Politics of Ontario. Ed. Graham White. Toronto: University of Toronto Press. 418-441.

Woolstencroft, Peter. (1997a). "Reclaiming the 'Pink Palace': The Program Conservative Party comes in from the Cold." The Government and Politics of Ontario. Ed. Graham White. Toronto: University of Toronto Press. 365-401. 
Woolstencroft, Peter. (1997b). "More than a Guard Change: Politics in the New Ontario." Revolution at Queen's Park: Essays on Governing Ontario. Ed. Sid Noel. Toronto: James Lorimer \& Co. 38-54.

Worchester, Robert, Roger Mortimore and Brian Gosschalk. (2001). "The 2001 General Election." Paper presented at the World Association for Public Opinion Research Annual Conference. 21 September.

Workman, Thom. (1999). "Hegemonic Modulation and the Discourse of Fiscal Crisis." Studies in Political Economy. 59: 61-89.

World Bank. (1991). World Development Report 1991: The Challenge of Development. New York: Oxford University Press.

Wright, John. (2003). "Whom do We trust?" Reader's Digest. February: 164-5.

Wright, Lisa. (1997). "Tension builds at Legislature." Toronto Star. 2 April 1997: A9.

Yankelovitch, Daniel. (1991). Coming to Public Judgment: Making Democracy Work in a Complex World. New York: Syracuse University Press.

Young, T.R. (1985). "Public Opinion, Mass Opinion and Social Opinion." Popular Culture and Media Events: The Critical Communications Review. Ed. Vincent Mosco and Janet Wasco. Vol. 3. Norwood, NJ: Ablex. 259-278. 